sתîñn

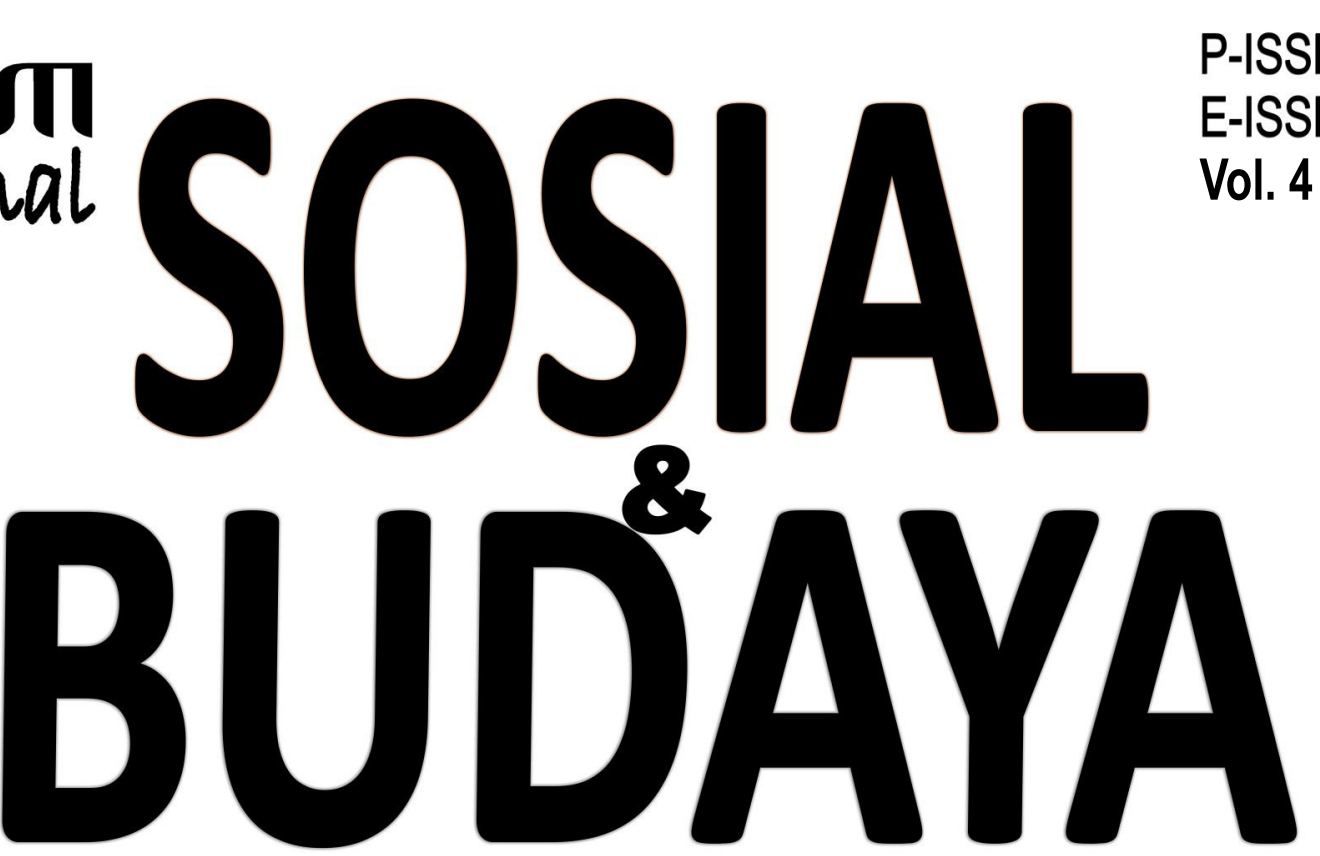

P-ISSN: 2356-1459 E-ISSN: 2654-9050 Vol. 4 No. 1 (2017)
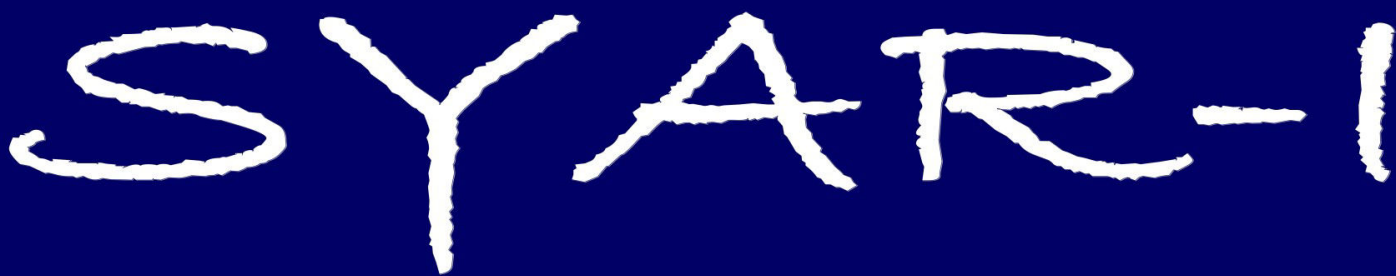

Interkoneksi Mahkamah Konstitusi Dengan Mahkamah Agung; Studi Implementasi Putusan Tentang Nasab Anak Mesraini

Perempuan Dalam Penegakan Hukum di Indonesia; Studi Peran Perempuan di Pengadilan Agama DKI Jakarta Kamarusdiana, Sri Hidayati

Transformasi Pendidikan Pancasila dan Wawasan Kebangsaan Bagi Generasi Milenial Untuk Revitalisasi Anti Korupsi

Supriyadi Ahmad

Korelasi Hak Asasi Manusia dan Hukum Islam

Daniel Alfaruqi

Pola Perlindungan Anak Di Negara-Negara Muslim

Resti Hedi Juwanti

Kasus Pelecehan Seksual Dalam Transportasi Umum Menurut Putusan Pengadilan Negeri Jakarta Pusat Iqbal Ramdhani

Kekerasan Dalam Perkawinan dan Nusyuz Dalam Hukum Keluarga di Turki, Malaysia, Sudan, Yordan, dan Indonesia

Fitriyani Zein 


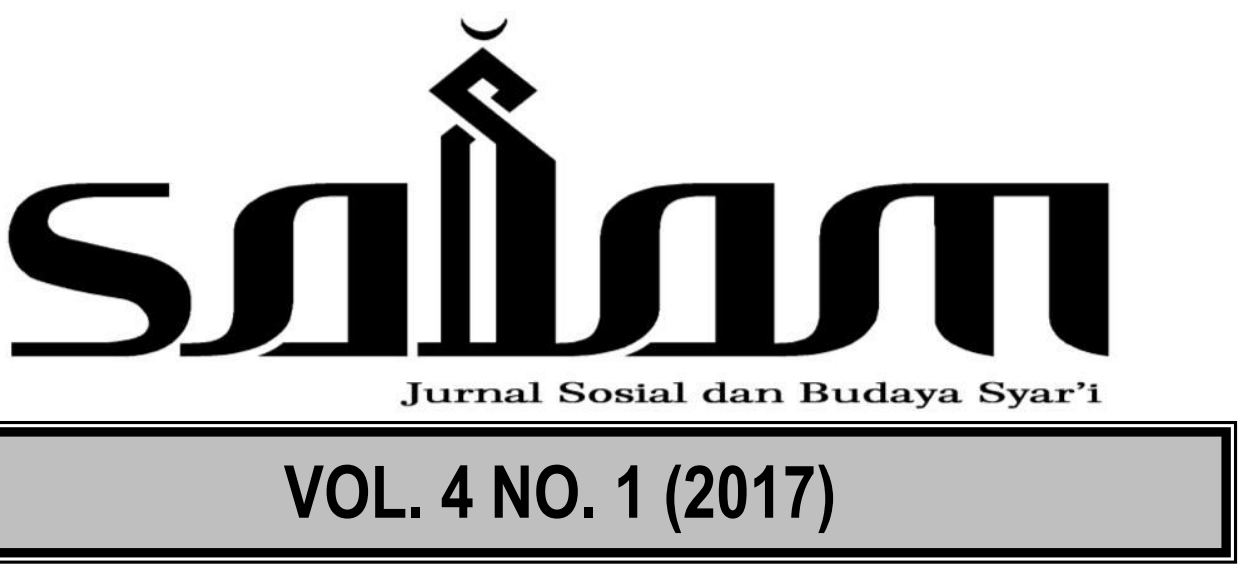

Diterbitkan oleh Fakultas Syariah dan Hukum Universitas Islam Negeri (UIN) Syarif Hidayatullah Jakarta.

Salam; Jurnal Sosial dan Budaya Syar-i mengkhususkan diri dalam pengkajian ilmu-ilmu Sosial dan Budaya dalam dimensi Syariah.

Terbit tiga kali dalam satu tahun di setiap bulan April, Agustus, dan Desember.

Redaktur Ahli
Muhammad Amin Suma (UIN Syarif Hidayatullah Jakarta)
A Salman Maggalatung (UIN Syarif Hidayatull ah Jakarta)
Asep Saepudin Jahar (UIN Syarif Hidayatullah Jakarta)
Ahmad Mukri Aji (UIN Syarif Hidayatullah Jakarta)
JM Muslimin (UIN Syarif Hidayatullah Jakarta)
Muhammad Munir (IIU Islamabad Pakistan)
Euis Amalia (UIN Syarif Hidayatullah Jakarta)
Tim Lindsey (Melbourne University Australia)
Raihanah Azahari (University Malaya Malaysia)
Ahmad Tholabi (UIN Syarif Hidayatullah Jakarta)
Ahmad Hidayat Buang (University Malaya Malaysia)

Pemimpin Redaksi

Nur Rohim Yunus

Sekretaris Redaksi

Muhammad Ishar Helmi

Redaktur Pelaksana

Mara Sutan Rambe

Indra Rahmatullah

\section{Editor Bahasa Inggris \\ Fitria}

Tata Usaha

Erwin Hikmatiar

\section{Alamat Redaksi}

Fakultas Syariah dan Hukum UIN Syarif Hidayatullah Jakarta

J1. Ir. H. Juanda 95 Ciputat Jakarta 15412 Telp. (62-21) 74711537, Faks. (62-21) 7491821

Website: www.fsh-uinjkt.net, E-mail: jurnal.salam@uinjkt.ac.id

Permalink: http://journal.uinjkt.ac.id/index.php/salam 


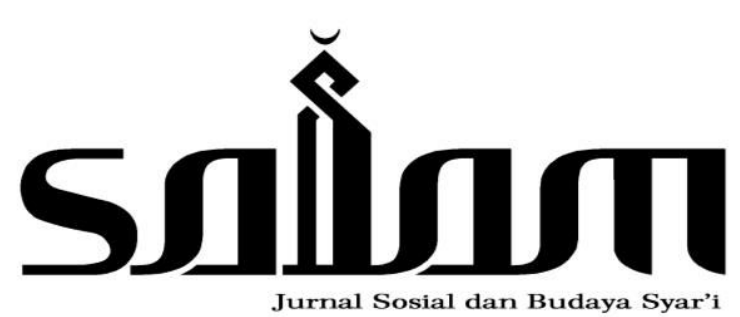

Menyambut baik kontribusi dari para ilmuwan, sarjana, profesional, dan peneliti dalam disiplin ilmu hukum untuk dipublikasi dan disebarluaskan setelah melalui mekanisme seleksi naskah, telaah mitra bebestari, dan proses penyuntingan yang ketat. 


\section{DAFTAR ISI}

1 Interkoneksi Mahkamah Konstitusi Dengan Mahkamah Agung;

Studi Implementasi Putusan Tentang Nasab Anak

Mesraini

27 Perempuan Dalam Penegakan Hukum di Indonesia;

Studi Peran Perempuan di Pengadilan Agama DKI Jakarta

Kamarusdiana, Sri Hidayati

43 Transformasi Pendidikan Pancasila dan Wawasan Kebangsaan Bagi Generasi Milenial Untuk Revitalisasi Anti Korupsi

Supriyadi Ahmad

57 Korelasi Hak Asasi Manusia dan Hukum Islam

Daniel Alfaruqi

77 Pola Perlindungan Anak Di Negara-Negara Muslim

Resti Hedi Juwanti

95 Kasus Pelecehan Seksual Dalam Transportasi Umum

Menurut Putusan Pengadilan Negeri Jakarta Pusat

Iqbal Ramdhani

121 Kekerasan Dalam Perkawinan dan Nusyuz Dalam Hukum Keluarga di Turki, Malaysia, Sudan, Yordan, dan Indonesia

Fitriyani Zein 



\title{
Interkoneksi Mahkamah Konstitusi \\ Dengan Mahkamah Agung; Studi Implementasi Putusan Tentang Nasab Anak *
}

\author{
(Interconnection Between Constitutional Court and Supreme Court: The Study of \\ The Implementation of the decree on child's descent)
}

\author{
Mesraini \\ FSH UIN Syarif Hidayatullah Jakarta. \\ Jl. Ir. H. Juanda No. 95 Ciputat. \\ Email: mesraini@uinjkt.ac.id
}

doi $10.15408 /$ sjsbs.v4i1.7866

\begin{abstract}
:
This article examines the interconnection between constitutional court and Supreme Court, with a special reference to the situation when Supreme Court decreed after the constitutional court decree. For the purpose of study, I use the decree on the child's descent case proposed by Machica Mohtar to examine the interconnection of these two courts. By understanding how effective are the constitutional court decrees and their connection with the position of Supreme Court, I find that the interconnection between these religious court-high religious courts and constitutional court wellmanaged enough. Constitutional court decree has been used as the basis for the court decrees. Nevertheless, Supreme Court tends not to place constitutional court decree for a permanent legal force (inkracht). As a result, the connection between constitutional court and Supreme Court has not been seen in its proper level. In another aspect, the implementation of law in Indonesia has shown a shifting from civil law system to those mixed between civil law and common law systems. In this regard, this shifting indicates that not only does a judge decree based on a procedural-justice, but he/she also takes a substantive-justice into consideration.
\end{abstract}

Key Words: Constitutional Court, Supreme Court, Child's Descent

\begin{abstract}
Abstrak:
Tulisan ini mengungkap hubungan antara MK dan MA, terutama ketika MA menetapkan putusan pasca putusan MK. Yang dijadikan instrumen dalam menguji interkoneksi kedua lembaga itu adalah kasus nasab anak yang diajukan Machica Mochtar. Dengan mengetahui tingkat implementatif ini akan diketahui tingkat efektivitas putusan MK di satu sisi, dan interkoneksi lembaga negara di bidang yudikatif MK dan MA di sisi lain. Penelitian hukum ini menemukan bahwa interkoneksi antara PA-PTA dengan MK cukup baik. Putusan MK dijadikan dasar penetapan putusan pengadilan. Namun, MA cenderung tidak mendudukkan putusan MK sebagai putusan final-mengikat, sehingga antara MK dengan MA belum menunjukkan hubungan semestinya. Pada aspek tertentu, terdapat pergeseran penerapan hukum di Indonesia, dari sistem civil law menuju sistem hukum campuran antara sistem civil law dengan sistem common law. Pergeseran ini menunjukkan hakim bukan hanya memutuskan suatu perkara berdasarkan keadilan-prosedural, tetapi juga keadilan-substantif.
\end{abstract}

Kata kunci: Mahkamah Konstitusi, Mahkamah Agung, Nasab Anak

* Diterima tanggal naskah diterima: 12 Februri 2017, direvisi: 22 Maret 2017, disetujui untuk terbit: 20 April 2017. 


\section{Pendahuluan}

Mahkamah Konstitusi Republik Indonesia, selanjutnya ditulis MK, merupakan salah satu lembaga tinggi negara yang memiliki kedudukan yang sederajat dan sama dengan Mahkamah Agung, selanjutnya ditulis MA. Baik MK maupun MA, keduanya merupakan lembaga negara yang dibentuk berdasarkan UUD 1945. ${ }^{1}$ MK berdiri sejak 17 Agustus 2003, sementara MA sudah ada sejak 19 Agustus 1945. ${ }^{2}$ Hadirnya MK membawa harapan untuk mewujudkan keadilan yang masih belum 'terfasilitasi' dalam kekuasaan kehakiman di Indonesia. Beberapa persoalan bangsa yang awalnya tidak tersentuh (untouchable) oleh hukum, kini dapat diafirmasi oleh MK. ${ }^{3}$

Merujuk pasal 24 C ayat (1) UUD 1945 yang ditegaskan kembali dalam pasal 10 ayat (1) Undang-Undang Nomor 24 Tahun 2003, MK menjalankan fungsi untuk menguji konstitusionalitas UU. MK menilai dan menguji norma UU apakah berlawanan dengan konstitusi sebagai hukum tertinggi (fundamental law) atau tidak. Produk hukum seperti UU, meski telah ditetapkan oleh Pemerintah dan DPR dengan cara demokratis, belum tentu hasilnya mencerminkan nilainilai dari cita hukum dan nilai-nilai konstitusi. Oleh karenanya, putusan MK sama kedudukannya dengan UU. Sifat putusan MK itu erga omnes yang berlaku bagi semua pihak, bukan hanya pihak yang berperkara, ${ }^{4}$ serta bersifat final dan mengikat. Putusan MK langsung memperoleh kekuatan hukum tetap sejak diucapkan dan tidak ada upaya hukum yang dapat ditempuh untuk menggugat

\footnotetext{
${ }^{1}$ Selain MK dan MA, ada organ negara lain yang secara langsung menerima kewenangan dari UUD NRI 1945, sebagaimana disebutkan dalam Pasal 24 C UUD NRI 1945. Organ tersebut adalah Dewan Perwakilan Rakyat, Dewan Perwakilan Daerah, Majelis Permusyawaratan Rakyat, Badan Pemeriksa Keuangan, Presiden dan Wakil Presiden. Dengan demikian, lembaga-lembaga yang ada dapat dibedakan antara kewenangan organ negara berdasarkan perintah UUD (constitutionally entrusted power), dan kewenangan organ negara yang hanya berdasarkan perintah UU (legislatively entrusted power), dan bahkan dalam kenyataannya ada pula lembaga atau organ yang kewenangannya berasal dari atau bersumber dari Keputusan Presiden belaka. Baca lebih lanjut Jimly Asshiddiqie, "Kedudukan Mahkamah Konstitusi dalam Struktur Ketatanegaraan Indonesia", Makalah disampaikan dalam Seminar di UNS, pada Kamis, 2 September 2004, diunduh dari www.hukumonline.com tanggal 07 Februari 2015.

${ }^{2}$ Lihat Mahkamah Agung Republik Indonesia, Laporan Tahunan 2010, Februari 2011, h. 17.

${ }^{3}$ Bambang Sutiyoso, "Pembentukan Mahkamah Konstitusi Sebagai Pelaku Kekuasaan Kehakiman di Indonesia", dalam Jurnal Konstitusi, Vol. 7, No. 6, Desember 2010, Jakarta: Mahkamah Konstitusi, h. 26.

${ }^{4}$ Hakim Konstitusi Arsyad Sanusi menjelaskan perbedaan putusan MK dengan MA. Dikatakan Arsyad, putusan MK bersifat erga omnes yang berarti mengikat dan harus dipatuhi oleh setiap warga negara. Selain itu putusan MK bersifat final, tidak ada lagi upaya hukum seperti banding, kasasi dan lainnya. Sedangkan putusan MA bersifat inter partes yang hanya mengikat para pihak bersengketa dan diperkenankan melakukan upaya hukum seperti banding, kasasi dan lainnya. Lihat Anonim, "Putusan MK Bersifat Erga Omnes" dalam http://www.mahkamahkonstitusi.go.id/index.php?page=website. BeritaInternal Lengkap\&id =4044, diunduh pada 27 Maret 2015.
} 
putusan MK tersebut. ${ }^{5}$ Sifat final dalam putusan MK ini mencakup pula kekuatan hukum yang mengikat (final and binding), bukan hanya pihak yang berperkara. ${ }^{6}$ Oleh karena putusan MK itu sebagai UU dan sifatnya erga omnes serta final dan mengikat (final and binding) maka MA pun harus tunduk atas putusan tersebut.

Dalam konteks ini, relasi MK dengan MA terutama pada putusan yang telah dihasilkan akan diuji. Sejauhmana kekuatan hukum putusan MK yang bersifat erga omnes itu diimplementasikan dalam putusan MA, termasuk di dalamnya putusan lembaga peradilan di bawah naungan MA. Putusan yang akan diteliti adalah Putusan MK Nomor 46/PUU-VIII/2010 Tanggal 13 Februari 2012 yang diucapkan dalam Sidang Pleno MK terbuka untuk umum pada hari Jumat tanggal 17 Pebruari 2012. Putusan MK ini mengabulkan uji materiil UU Nomor 1 Tahun 1974 tentang Perkawinan (selanjutnya disebut UU Perkawinan) yang diajukan oleh Hj. Aisyah Mochtar alias Machica binti H. Mochtar Ibrahim yang meminta puteranya Muhammad Iqbal Ramadhan agar diakui sebagai anak almarhum Moerdiono. Putusan MK itu mengadili perkara konstitusi pada tingkat pertama dan terakhir, menjatuhkan putusan dalam perkara permohonan pengujian UU Perkawinan terhadap UUD NRI 1945.

Dalam putusan MK itu, permohonan terhadap Pasal 2 ayat (2) UU Perkawinan tidak dikabulkan sebab perkawinan yang dicatatkan adalah untuk mencapai tertib administrasi. Sementara permohonan terhadap pasal 43 ayat (1) UU Perkawinan dikabulkan. Hubungan anak dengan laki-laki sebagai bapak tidak semata-mata karena adanya ikatan perkawinan, tetapi dapat juga didasarkan pada pembuktian adanya hubungan darah antara keduanya. Dengan demikian, terlepas dari soal prosedur atau administrasi perkawinannya, anak yang dilahirkan harus mendapat perlindungan hukum.

Putusan MK Nomor 46/PUU-VIII/2010 tersebut semestinya dijadikan sebagai dasar dalam memberikan putusan, lebih-lebih dalam kasus yang sama di lingkungan lembaga peradilan MA, termasuk di dalamnya putusan pada PA (Pengadilan Agama), PTA (Pengadilan Tinggi Agama) di tingkat banding, dan MA di tingkat kasasi. Pada ketiga institusi kehakiman itu, akan dicari tahu bagaimana implementasinya terutama yang terkait dengan pengaduan Machica sebagaimana pokok perkara dalam putusan MK tersebut. Dengan mengetahui implementasi putusan pada institusi kehakiman di bawah naungan MA itu dapat diketahui sejauhmana interkoneksi antara lembaga MK dengan MA.

Tulisan ini akan menguji interkoneksi antara MK dan MA dengan indikator kasus yang diajukan Machica pasca putusan MK Nomor 46/PUUVIII/2010. Implementasi putusan di lingkungan lembaga peradilan MA, termasuk putusan PA di tingkat pertama, PTA di tingkat banding, dan MA di

\footnotetext{
${ }^{5}$ Lihat UUD 1945 Pasal 24C ayat (1) dan Pasal 27 UU Nomor 24 Tahun 2003 tentang MK.

${ }^{6}$ Lihat penjelasan Pasal 10 UU Nomor 24 Tahun 2003 tentang MK.
} 
tingkat kasasi, pasca terbitnya putusan MK akan dijadikan batasan penelitian ini. Oleh karenanya, diajukan pertanyaan "Bagaimana hubungan antara MK dan MA sebagai lembaga yudikatif, terutama MA menetapkan putusan pasca terbitnya putusan MK?"

Untuk menjawab permasalahan tersebut digunakan metode hukum yuridis-normatif, yakni metode penelitian hukum yang dilakukan dengan meneliti bahan pustaka atau data sekunder. ${ }^{7}$ Dalam kaitan itu, akan digunakan pendekatan perundang-undangan (statute approach) dan pendekatan konsep (conceptual approach) yang diarahkan untuk memahami regulasi dan konsep terkait kedudukan, persamaan dan perbedaan MK dan MA, termasuk di dalamnya PA, PTA, dan hal ihwal yang terkait dengan nasab anak sebagaimana putusan MK Nomor 46/PUU-VIII/2010. ${ }^{8}$

Penelitian ini dilakukan di PA, PTA, dan MA, dengan fokus pada putusan tingkat pertama di PA Tigaraksa dan PA Jakarta Selatan, putusan tingkat banding di PTA DKI Jakarta, dan putusan tingkat kasasi di MA yang berkantor di Jakarta. Metode pengumpulan data yang dilakukan adalah studi kepustakaan dan studi lapangan. Cara yang digunakan untuk menganalisis data dari studi kepustakaan dan penelitian lapangan adalah dengan metode analisis deskriptif-kualitatif, yaitu metode analisis data yang mengelompokkan dan menyeleksi data yang diperoleh dari penelitian lapangan menurut kualitas dan kebenarannya, kemudian dihubungkan dengan teori-teori, asas-asas, dan kaidah-kaidah hukum yang diperoleh dari studi kepustakaan sehingga diperoleh jawaban atas permasalahan yang dirumuskan.

\section{MA dan MK sebagai Pelaksana Kekuasaan Kehakiman}

Kekuasaan kehakiman adalah kekuasaan negara yang merdeka untuk menyelenggarakan peradilan guna menegakkan hukum dan keadilan berdasarkan Pancasila dan UUD NRI 1945 demi terselenggaranya Negara Hukum Republik Indonesia. ${ }^{9}$ Landasan konstitusional bagi kekuasaan

\footnotetext{
${ }^{7}$ Soerjono Soekanto \& Sri Mamudji, Penelitian Hukum Normatif: Suatu Tinjauan Singkat, (Jakarta: Rajawali Pers, 2001), h. 13-14.

${ }^{8}$ Johnny Ibrahim, Teori, Metode dan Penelitian Hukum Normatif, (Malang: Bayumedia Publising, 2007), h. 300.

${ }^{9}$ Baca UU Nomor 48 tahun 2009 tentang Kekuasaan Kehakiman pasal 1 angka 1. Apabila bunyi pasal tersebut dibandingkan dengan dua UU tentang kekuasan kehakiman sebelumnya, yaitu UU Nomor 14 tahun 1970 dan UU Nomor 4 tahun 2004, tampak ada definisi kekuasaan kehakiman yang berbeda. Pada UU Nomor 14 tahun 1970 dan UU Nomor 4 Tahun 2004 pasal 1 disebutkan "Kekuasaan kehakiman adalah kekuasaan negara yang merdeka untuk menyelenggarakan peradilan guna menegakkan hukum dan keadilan berdasarkan Pancasila, demi terselenggaranya Negara Hukum Republik Indonesia." Artinya, dasar kekuasaan kehakiman dalam Pasal 1 UU Nomor 14 Tahun 1970 dan UU Nomor 4 Tahun 2004 adalah Pancasila saja, tidak beserta UUD 1945.
} 
kehakiman untuk melakukan fungsi peradilan tersebut adalah Perubahan Ketiga UUD 1945 Pasal 24 ayat (1), yang menyebutkan bahwa: “Kekuasaan kehakiman merupakan kekuasaan yang merdeka untuk menyelenggarakan peradilan guna menegakkan hukum dan keadilan." Perubahan Ketiga UUD NRI Tahun 1945 ini telah membawa perubahan mendasar dalam aspek ketatanegaraan, termasuk pelaksanaan kekuasaan kehakiman. Sebelum dilakukan Perubahan Ketiga UUD NRI Tahun 1945, kekuasaan kehakiman diatur dalam pasal 24 dan 25 UUD 1945. ${ }^{10}$ Berdasarkan pasal 24, kekuasaan kehakiman hanya dipegang dan dilakukan oleh MA, dengan badan-badan peradilan yang ada di bawahnya. Pada saat itu tidak dikenal kekuasaan kehakiman yang lain, di luar MA. Sebagai turunan atas ketentuan pasal 24 UUD 1945, lahir UU Nomor 14 Tahun 1970 tentang Kekuasaan Kehakiman sebagai pelaksanaan pembentukan badan-badan peradilan. ${ }^{11}$ UU Nomor 14 Tahun 1970 menegaskan bahwa MA sebagai pelaksana kekuasaan kehakiman merupakan Pengadilan Negara Tertinggi (Highest State Court). Dalam kedudukannya sebagai Pengadilan Negara Tertinggi, MA bertindak sebagai peradilan kasasi serta melakukan pengawasan tertinggi atas perbuatan pengadilan lain yang meliputi semua lingkungan peradilan, yaitu Peradilan Umum, Peradilan Agama, Peradilan Militer dan Peradilan Tata Usaha Negara.

Dalam Perubahan Ketiga UUD NRI Tahun 1945 tersebut, kekuasaan kehakiman diatur dalam lima pasal dengan memuat beberapa ayat, yaitu pasal 24, pasal 24A, pasal 24B, pasal 24C dan pasal 25. Dalam perubahan tersebut ditegaskan bahwa kekuasaan kehakiman di Indonesia dilaksanakan oleh MA dengan badan peradilan di bawahnya dan oleh MK. Dengan demikian, Perubahan Ketiga UUD NRI 1945 ini berimplikasi atas adanya dua pelaku kekuasaan kehakiman yang kedudukannya setara, yaitu MA dan MK. Sebagai langkah penyesuaian terhadap Perubahan Ketiga UUD NRI Tahun 1945 itu, dilakukanlah perubahan atas UU kehakiman, sehingga lahirlah UU Nomor 4 Tahun 2004 yang menggantikan UU Nomor 14 Tahun 1970. Berselang lima tahun kemudian, UU Nomor 4 Tahun 2004 pun dinyatakan tidak berlaku dan digantikan dengan UU Nomor 48 tahun 2009.

\footnotetext{
${ }^{10}$ Pasal 24 UUD NRI Tahun 1945 berbunyi: “ (1) Kekuasaan kehakiman dilakukan oleh sebuah MA dan lain-lain badan kehakiman menurut UU; (2) Susunan dan kekuasaan badan-badan kehakiman itu diatur dengan UU."

${ }^{11}$ Sebelum UU Nomor 14 Tahun 1970, sebenarnya sudah diterbitkan UU Nomor 19 Tahun 1964 tentang Kekuasaan Kehakiman pada masa Orde Lama. Hanya saja, UU ini dianggap tidak merupakan pelaksanaan murni pasal 24 UUD NRI Tahun 1945, karena memuat ketentuan yang bertentangan dengan prinsip kekuasaan kehakiman yang merdeka, seperti yang digariskan pasal 24 ayat (1), yaitu memberi kewenangan bagi Presiden mencampuri pelaksanaan peradilan. Lihat M. Yahya Harahap, Kekuasaan Mahkamah Agung: Pemeriksaan Kasasi dan Peninjauan Kembali Perkara Perdata, (Jakarta: Sinar Grafika, 2008), h. 12.
} 


\section{Kesamaan MA dan MK}

Sebagai pelaksana kekuasaan kehakiman di Indonesia, terdapat sejumlah persamaan antara MA dan MK, yaitu sebagai berikut.

Pertama, ditinjau dari sisi landasan konstitusional, MA dan MK samasama merupakan lembaga negara yang dibentuk berdasarkan amanah UUD NRI Tahun 1945, sebagaimana yang disebutkan dalam pasal 24 ayat (2). Kedua, dilihat dari segi kedudukan, MA dan MK sama-sama pelaksana cabang kekuasaan kehakiman yang merdeka dan terpisah dari cabang-cabang kekuasaan lain, yaitu pemerintah (executive) dan lembaga permusyawaratan-perwakilan (legislature). Ketiga, MA dan MK sama-sama bertujuan untuk menegakkan hukum dan keadilan berdasarkan Pancasila dan UUD NRI Tahun 1945 demi terselenggaranya negara Repubik Indonesia. Supremasi hukum dan mewujudkan keadilan harus tercermin dalam putusan MA dan MK. Keempat, dari aspek asas penyelenggaraan peradilan di Indonesia, MA dan MK samasama harus memperhatikan dan terikat dengan asas-asas penting dalam menyelenggarakan peradilan, di antaranya: [a] Asas persamaan di hadapan hukum atau equality before the law; [b] Asas kebebasan hakim; [c] Asas peradilan diselenggarakan dengan sederhana, cepat dan biaya ringan; [d] Asas sidang terbuka untuk umum; [e] Asas hak untuk didengar secara seimbang (audi et aleram partem); [f] Asas kepentingan umum; [g] Asas praduga tak bersalah; [h] Asas ius curia novit, bahwa pengadilan dilarang menolak suatu perkara yang diajukan dengan dalih hukum tidak ada atau kurang jelas, melainkan wajib untuk mengadilinya. Asas ini mengarahkan hakim pada proses penemuan hukum (recht vinding) untuk menemukan keadilan. [i] Asas ne bis in idem, yang berarti tidak ada pengadilan terhadap orang yang sama dan perkara yang sama apabila sudah ada putusan hakim terhadap hal itu. ${ }^{12}$

${ }^{12}$ Asas tersebut disari dari beberapa buku, yaitu: Didit Hariadi Estiko dan Suhartono (ED), Mahkamah Konstitusi: Lembaga Negara Baru Pengawal Konstitusi, (Jakarta: P31 Sekretariat Jenderal DPR RI, Agarino Abadi, 2003), h. 52-53. Lihat juga Andi Hamzah, Hukum Acara Pidana Indonesia, (Jakarta: Sapta Artha Jaya, 1996), h. 10-24 dan A. Ridwan Halim, Pengantar Tata Hukum Indonesia dalam Tanya Jawab, (Jakarta: Ghalia Indonesia, 1985), h. 139. Bandingkan juga dengan Maruar Siahaan, Hukum Acara Mahkamah Konstitusi Republik Indonesia, (Jakarta: Sekretariat Jenderal dan Kepaniteraan MK RI, 2006), h. 61-81. Selain itu, Bambang Sutiyoso dan Sri Hastuti Puspitasari menyatakan bahwa terdapat beberapa asas hukum kekuasaan kehakiman diantaranya: [a] Asas kebebasan hakim; [b] Hakim bersifat menunggu; [c] Pemeriksaan berlangsung terbuka; [d] Hakim aktif; [e] Asas hakim bersifat pasif (Tut Wuri); [f] Asas kesamaan (Audi et Alteram Partem); [g] Asas objektivitas; dan [h] Putusan disertai alasan (Motiverings Plicht). Lihat Bambang Sutiyoso dan Sri Hastuti Puspitasari, Aspek-Aspek Perkembangan Kekuasaan Kehakiman di Indonesia, ( Yogyakarta: UII Press, 2005), h. 66. 


\section{Perbedaan MA dan MK}

Perbedaan antara MA dengan MK dapat dilihat dalam tabel berikut:

\begin{tabular}{|c|c|c|}
\hline Perbedaan & MA & MK \\
\hline $\begin{array}{l}\text { Tugas } \\
\text { dan Wewenang }\end{array}$ & $\begin{array}{l}\text { a. menguji peraturan yang di } \\
\text { bawah UU terhadap UU. } \\
\text { b. mengadili sengketa kewenangan } \\
\text { mengadili dalam lingkungan } \\
\text { peradilan di bawahnya. } \\
\text { c. mengadili permohonan kasasi } \\
\text { dari lingkungan peradilan di } \\
\text { bawahnya. } \\
\text { d. mengadili permohonan } \\
\text { peninjauan kembali. } \\
\text { e. mengawasi lembaga peradilan } \\
\text { yang di bawahnya. } \\
\text { f. mengawasi penasehat hukum } \\
\text { dan notaris. } \\
\text { g. memberikan pertimbangan } \\
\text { hukum kepada presiden dalam } \\
\text { permohonan grasi dan } \\
\text { rehabilitasi. } \\
\text { h. memberikan pertimbangan } \\
\text { dalam bidang hukum bagi } \\
\text { lembaga tinggi negara. }\end{array}$ & $\begin{array}{l}\text { a. menguji UU terhadap UUD NRI } \\
\text { Tahun } 1945 . \\
\text { b. mengadili sengketa kewenangan } \\
\text { lembaga negara. } \\
\text { c. mengadili pembubaran partai } \\
\text { politik. } \\
\text { d. mengadili perselisihan tentang } \\
\text { hasil pemilihan umum. } \\
\text { e. memberikan putusan atas } \\
\text { pendapat DPR mengenai } \\
\text { dugaan pelanggaran oleh } \\
\text { Presiden dan/atau Wakil } \\
\text { Presiden. }\end{array}$ \\
\hline $\begin{array}{l}\text { Struktur } \\
\text { Kekuasaan } \\
\text { Kehakiman }\end{array}$ & $\begin{array}{l}\text { MA memiliki cabang kekuasaan } \\
\text { yang terdiri dari badan peradilan di } \\
\text { bawahnya dalam lingkungan } \\
\text { peradilan umum, peradilan agama, } \\
\text { peradilan militer dan peradilan tata } \\
\text { usaha negara. }\end{array}$ & $\begin{array}{l}\text { MK tidak memiliki cabang } \\
\text { kekuasaan kehakiman, MK hanya } \\
\text { ada satu dan berkedudukan di } \\
\text { lbukota Negara Republik Indonesia. }\end{array}$ \\
\hline $\begin{array}{l}\text { Pencalonan } \\
\text { Hakim }\end{array}$ & $\begin{array}{l}\text { Calon Hakim Agung diusulkan } \\
\text { Komisi Yudisial kepada DPR untuk } \\
\text { mendapat persetujuan dan } \\
\text { selanjutnya ditetapkan sebagai } \\
\text { Hakim Agung oleh presiden. (Lihat } \\
\text { pasal 24A ayat [3] UUD 1945) }\end{array}$ & $\begin{array}{l}\text { Calon Hakim Konstitusi diajukan } \\
\text { masing-masing } 3 \text { orang oleh MA, } 3 \\
\text { orang oleh Dewan Perwakilan } \\
\text { Rakyat, dan } 3 \text { orang oleh presiden, } \\
\text { yang selanjutnya ditetapkan } \\
\text { sebagai Hakim Konstitusi oleh } \\
\text { presiden. (Lihat pasal } 24 C \text { ayat [3] } \\
\text { UUD 1945) }\end{array}$ \\
\hline Jumlah Hakim & $\begin{array}{l}\text { Jumlah Hakim Agung paling banyak } \\
60 \text { orang. } \\
\text { (Lihat pasal } 4 \text { UU 5/2004) }\end{array}$ & $\begin{array}{l}\text { Jumlah Hakim Konstitusi sebanyak } \\
9 \text { orang, yang terdiri atas seorang } \\
\text { ketua merangkap anggota, seorang } \\
\text { wakil ketua merangkap anggota, } \\
\text { dan } 7 \text { orang anggota hakim } \\
\end{array}$ \\
\hline
\end{tabular}




\begin{tabular}{|c|c|c|}
\hline & $\begin{array}{l}\text { Dalam persidangan, pada dasarnya } \\
\text { bersifat majlis dengan jumlah hakim } \\
\text { minimal sebanyak } 3 \text { orang, kecuali } \\
\text { UU mengatur lain. }\end{array}$ & $\begin{array}{l}\text { MK. (Lihat pasal } 4 \text { UU 8/2011) } \\
\text { Dalam persidangan, pada dasarnya } \\
\text { hakim harus berjumlah } 9 \text { orang, } \\
\text { kecuali dalam keadaan luar biasa } \\
\text { boleh dilakukan persidangan } \\
\text { dengan jumlah hakim sebanyak } 7 \\
\text { orang. (Lihat pasal } 28 \text { UU 24/2003) }\end{array}$ \\
\hline \multirow[t]{2}{*}{ Sifat Putusan } & $\begin{array}{l}\text { a. Putusan Pengadilan di bawah } \\
\text { MA, yaitu PA \& PTA belum } \\
\text { memperoleh kekuatan hukum } \\
\text { tetap dan belum mengikat pada } \\
\text { saat dibacakan dalam sidang } \\
\text { pleno yang terbuka untuk umum. } \\
\text { Putusan itu baru mempunyai } \\
\text { kekuatan hukum tetap dan } \\
\text { mengikat apabila telah lewat } \\
\text { masanya sedangkan para pihak } \\
\text { tidak menempuh upaya hukum } \\
\text { Banding atau Kasasi. } \\
\text { Sedangkan terhadap putusan } \\
\text { MA, meskipun masih ada upaya } \\
\text { hukum yang ditempuh, yaitu } \\
\text { Peninjauan Kembali dan Grasi, } \\
\text { namun upaya hukum tersebut } \\
\text { tidak menghalangi eksekusi. }\end{array}$ & $\begin{array}{l}\text { a. Final and Binding. Putusan MK } \\
\text { langsung memperoleh kekuatan } \\
\text { hukum tetap dan juga langsung } \\
\text { mengikat serta sudah dapat } \\
\text { dieksekusi sejak diucapkan } \\
\text { dalam sidang pleno yang } \\
\text { terbuka untuk umum dan tidak } \\
\text { ada upaya hukum yang dapat } \\
\text { ditempuh terhadap putusan } \\
\text { tersebut. (Penjelasan Pasal } 10 \\
\text { ayat [1] UU 8/2011) }\end{array}$ \\
\hline & $\begin{array}{l}\text { b. Inter Partes. Putusan MA hanya } \\
\text { mengikat para pihak dan harus } \\
\text { dipatuhi hanya oleh para pihak } \\
\text { yang berperkara itu saja. }\end{array}$ & $\begin{array}{l}\text { b. Erga Omnes. Putusan MK } \\
\text { mengikat dan harus dipatuhi } \\
\text { oleh setiap warga negara, tidak } \\
\text { hanya oleh pihak yang } \\
\text { berperkara saja, karena } \\
\text { menyangkut kepentingan } \\
\text { umum. } .^{13}\end{array}$ \\
\hline
\end{tabular}

13 "Putusan MK Bersifat Erga Omnes", dalam http://www.mahkamahkonstitusi.go.id/ index.php?page=website.BeritaInternalLengkap\&id=4044, diunduh pada 27 Maret 2015. 


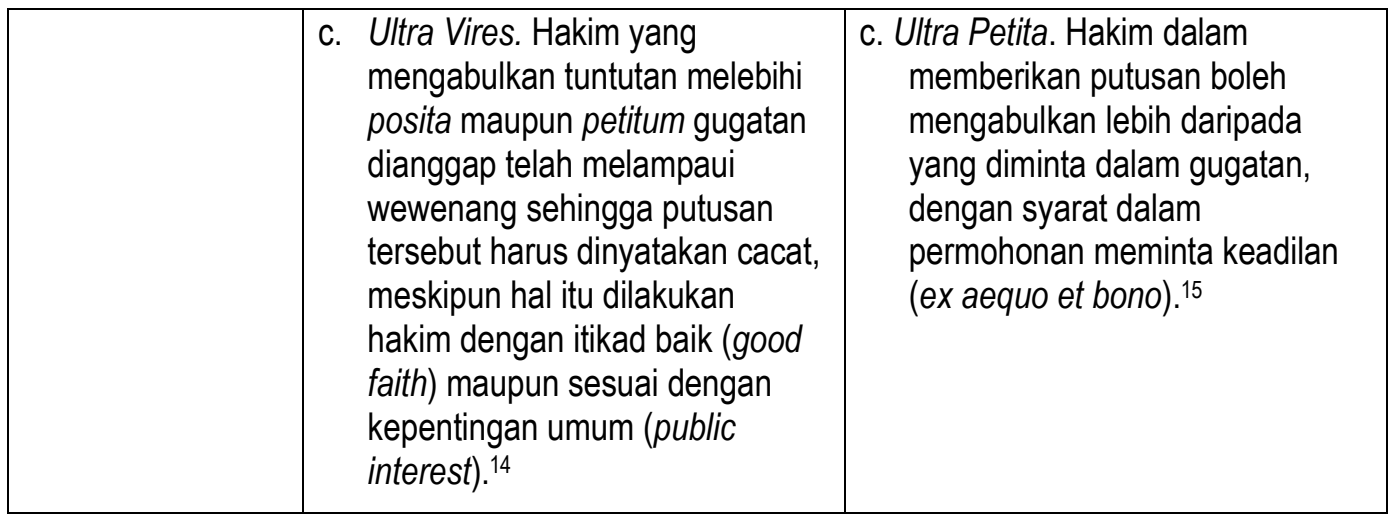

\section{Deskripsi Singkat Putusan MK Nomor 46/PUU-VIII/2010}

Putusan MK Nomor 46/PUU-VIII/2010 merupakan sebuah keputusan yang ditetapkan oleh hakim $\mathrm{MK}$ atas perkara permohonan judicial review terhadap beberapa ketentuan dalam UU Perkawinan Nomor 1 Tahun 1974, yaitu pasal 2 ayat (2) dan pasal 43 ayat (1). Permohonan judicial review (pengujian) terhadap materi UU Perkawinan ini diajukan oleh Machica dan anaknya, Iqbal. Alasan yang diusulkan bahwa kedua pasal dimaksud bertentangan dengan UUD NRI Tahun 1945 sehingga merugikan sebagian hak konstitusional para pemohon.

Pada tanggal 14 Juni 2010, Machica dan Iqbal mengajukan permohonan uji materiil UU Perkawinan yang diterima oleh Kepaniteraan MK dan dicatat pada Akta Penerimaan Berkas Permohonan Nomor 211/PAN.MK/2010 dan diregistrasi pada tanggal 23 Juni 2010 dengan Nomor 46/PUU-VIII/2010, yang telah diperbaiki dan diterima kembali di Kepaniteraan MK pada tanggal 9 Agustus 2010.

Machica dan Iqbal menyatakan bahwa mereka sudah memenuhi dua persyaratan yang ditentukan dalam setiap permohonan uji materil UU, yaitu: Pertama, sebagai Warga Negara Indonesia. Kedua, mereka berdua merupakan pihak yang secara langsung mengalami dan merasakan hak konstitusionalnya

${ }^{14}$ M. Yahya Harahap, Hukum Acara Perdata tentang Gugatan, Persidangan, Penyitaan, Pembuktian, dan Putusan Pengadilan, (Jakarta: Sinar Grafika, 2008), h. 801.

15 Dalam masalah ultra petita, MK banyak mendapat kritik. Pihak yang menolak ultra petita menganggap MK telah memasuki ranah legislatif, tidak sesuai asas hukum perdata yang melarang ultra petita serta ketentuan ultra petita sendiri tidak diatur dalam UUD 1945 atau pun dalam UU tentang MK. Sementara mantan Ketua MK, Jimly Asshiddiqie, menanggapi berbagai kritikan menegaskan bahwa putusan MK boleh saja memuat ultra petita jika pasal yang dimohonkan terkait pasal-pasal lain (jantung dari UU) dan larangan putusan mengandung ultra petita hanya berlaku di peradilan perdata. Sedangkan mantan Ketua Mahkamah Agung, Bagir Manan, membenarkan ultra petita di MK, asal saja dalam permohonan judicial review meminta keadilan (ex aequo et bono). Lebih lengkap, baca "Analisa Yuridis Putusan Ultra Petita Mahkamah Konstitusi dalam Menguji Undang-Undang Terhadap Undang-Undang Dasar", dalam https://ramsespurba.wordpress.com/2013/07/11/ analisa-yuridis-putusan-ultra-petita-mahkamahkonstitusi-dalam/, diakses 27 Maret 2015. 
dirugikan dengan diberlakukannya UU Perkawinan. Machica menyatakan bahwa pasal 2 ayat (1) UU Perkawinan yang menyatakan: "Perkawinan adalah sah, apabila dilakukan menurut hukum masing-masing agamanya dan kepercayaannya itu", berimplikasi secara hukum terhadap pernikahan dirinya dengan Moerdiono. Machica berkeyakinan bahwa pernikahan dirinya dengan Moerdiono pada tanggal 20 Desember 1993 di Jakarta itu pernikahan yang sah. Alasan yang dikemukakan Machica adalah pernikahannya itu telah memenuhi ketentuan sesuai dengan ajaran Islam yang mereka anut. Dari pernikahan tersebut, lahir seorang anak laki-laki bernama Iqbal. Namun, aqad pernikahan itu tidak dilakukan di hadapan Pegawai Pencatat Nikah, dan pernikahan mereka itu tidak dicatatkan dalam buku akta nikah sehingga mereka tidak memiliki kutipan akta nikah. Oleh karena ketiadaan kutipan akta nikah tersebut, Iqbal tidak dapat diperlakukan sebagaimana anak yang sah. Sebab, pada pasal 2 ayat (2) UU Perkawinan dinyatakan bahwa: "Tiap-tiap perkawinan dicatat menurut peraturan perundang-undangan yang berlaku." Kemudian Pasal 43 ayat (1) UU yang sama juga menetapkan bahwa: "Anak yang dilahirkan di luar perkawinan hanya mempunyai hubungan perdata dengan ibunya dan keluarga ibunya." Atas dasar itulah, Machica mengajukan permohonan itsbat nikah ke PA Tigaraksa, Tangerang, Banten. Namun, PA Tigaraksa tidak mengabulkan permohonan itsbat nikah dimaksud sebagaimana diputuskan dalam amar penetapan atas perkara Nomor 46/Pdt.P/2008/PA.Tgrs. tanggal 18 juni 2008.

Akhirnya, Machica dan Iqbal mengajukan permohonan uji materil pasal 2 ayat (2) dan pasal 43 ayat (1) UU Perkawinan yang merugikan hak konstitusional mereka berdua ke MK. Penerapan pasal 2 ayat (2) mengakibatkan perkawinan Machica dan Moerdiono tidak diakui menurut hukum, sedangkan penerapan pasal 43 ayat (1) mengakibatkan Iqbal tidak mempunyai hubungan perdata dengan ayahnya, dalam hal ini Moerdiono. Machica menjabarkan bahwa dengan diberlakukannya kedua pasal UU Perkawinan tersebut, hak-hak konstitusional mereka sebagai warga negara Indonesia yang dijamin oleh pasal 28B ayat (1) dan ayat (2) serta pasal 28D ayat (1) UUD NRI 1945 telah dirugikan.

Dari ketentuan UUD NRI 1945 itu, Machica memahami bahwa secara konstitusional, siapapun berhak melaksanakan pernikahan sepanjang itu sesuai dengan agama dan kepercayaannya masing-masing Akan tetapi, hak konstitusional itu telah diciderai oleh norma hukum pasal 2 ayat (2) UU Perkawinan yang mengharuskan sebuah pernikahan dicatat menurut peraturan perundang-undangan yang berlaku. Machica mempertanyakan, bagaimana mungkin norma agama direduksi oleh norma hukum sehingga perkawinan yang sah menjadi tidak sah?

Selain telah melanggar hak konstitusional anak, akibat dari ketentuan Pasal 43 ayat (1) UU Perkawinan juga menyebabkan beban psikis terhadap Iqbal. Hal ini disebabkan tidak adanya pengakuan dari ayah atas kehadiran Iqbal di dunia. Machica berpendapat bahwa UU Perkawinan merugikan mereka dan 
telah menimbulkan perlakuan yang diskriminatif. Oleh karena itu, Machica dan Iqbal memohon kepada MK agar berkenan memberikan putusan sebagai berikut:

1. Menerima dan mengabulkan permohonan uji materil pemohon untuk seluruhnya;

2. Menyatakan Pasal 2 ayat (2) dan Pasal 43 ayat (1) UU Perkawinan, bertentangan Pasal 28B ayat (1) dan ayat (2) serta Pasal 28D ayat (1) UUD NRI 1945;

3. Menyatakan Pasal 2 ayat (2) dan Pasal 43 ayat (1) UU Perkawinan, tidak mempunyai kekuatan hukum yang mengikat dengan segala akibat hukumnya; Atau jika Majelis Hakim berpendapat lain, maka dimohonkan putusan yang seadil-adilnya (ex aequo et bono).

Setelah membaca permohonan dari pemohon, mendengar keterangan dari para pemohon, memeriksa bukti-bukti dari para pemohon, mendengar keterangan ahli, mendengar dan membaca keterangan tertulis dari Pemerintah dan Dewan Perwakilan Rakyat, serta membaca kesimpulan tertulis dari para pemohon, selanjutnya MK dalam amar Putusan MK Nomor 46/PUU-VIII/2010 menyatakan mengabulkan permohonan Machica dan Iqbal untuk sebagian dan menolaknya untuk yang selainnya. Adapun permohonan yang dikabulkan hanyalah berkaitan dengan pasal 43 ayat (1) UU Perkawinan yang berbunyi: "Anak yang dilahirkan di luar perkawinan hanya mempunyai hubungan perdata dengan ibunya dan keluarga ibunya". MK memutuskan bahwa pasal 43 ayat (1) itu bertentangan dengan UUD NRI Tahun 1945 secara bersyarat (conditionally unconstitutional), yakni inkonstitusional sepanjang dimaknai menghilangkan hubungan perdata dengan laki-laki yang dapat dibuktikan berdasarkan ilmu pengetahuan dan teknologi dan/atau alat bukti lain menurut hukum ternyata mempunyai hubungan darah sebagai ayahnya, sehingga menurut MK, ayat tersebut harus dibaca, "Anak yang dilahirkan di luar perkawinan mempunyai hubungan perdata dengan ibunya dan keluarga ibunya serta dengan laki-laki sebagai ayahnya yang dapat dibuktikan berdasarkan ilmu pengetahuan dan teknologi dan/atau alat bukti lain menurut hukum mempunyai hubungan darah termasuk hubungan perdata dengan keluarga ayahnya".

MK memiliki pertimbangan bahwa secara alamiah, tidaklah mungkin seorang perempuan hamil tanpa terjadinya pertemuan antara ovum dan spermatozoa, baik melalui hubungan seksual (coitus) maupun melalui cara lain berdasarkan perkembangan teknologi yang menyebabkan terjadinya pembuahan. Oleh karena itu, tidak adil ketika hukum menetapkan anak yang lahir di luar perkawinan hanya memiliki hubungan dengan ibunya saja dan membebaskan laki-laki yang melakukan hubungan seksual dari tanggung jawabnya sebagai bapak dan sekaligus meniadakan hak-hak anak terhadap lelaki tersebut sebagai bapaknya. Menurut MK, hubungan anak dengan laki-laki sebagai bapak tidak semata-mata karena adanya ikatan perkawinan, tetapi juga 
dapat didasarkan pada pembuktian adanya hubungan darah antara anak dengan laki-laki tersebut. Dengan demikian, terlepas dari soal prosedur atau administrasi perkawinannya, status anak yang dilahirkan harus mendapat perlindungan hukum. Jika tidak demikian, yang dirugikan adalah anak yang dilahirkan di luar perkawinan, padahal anak tersebut tidak berdosa. Anak yang dilahirkan tanpa memiliki kejelasan status ayah seringkali mendapatkan perlakuan yang tidak adil dan stigma masyarakat yang cenderung kurang baik. Hukum harus memberi perlindungan dan keadilan terhadap status anak yang dilahirkan, termasuk terhadap anak yang perkawinan orangtuanya masih dipersengketakan.

\section{Putusan di Lingkungan Lembaga Peradilan MA Pasca Putusan MK}

Pasca putusan MK, Machica mengajukan perkara ke beberapa peradilan agama di lingkungan MA. Pertama, dalam bentuk permohonan (volunteer) diajukan ke PA Tigaraksa dan berlanjut pada tingkat Kasasi di MA. Kedua, dalam bentuk gugatan (contentious) diajukan ke PA Jakarta Selatan dan tingkat Banding di Pengadian Tinggi Agama Jakarta serta tingkat Kasasi di MA. Berikut uraiannya:

\section{Putusan atas Perkara Permohonan (Volunteer) Machica pada Pengadilan Agama Tigaraksa dan Mahkamah Agung}

Pada tanggal 6 Maret 2012, Machica mengajukan surat permohonan penetapan hubungan hukum anak luar kawin dengan ayah biologisnya ke PA Tigaraksa dengan register perkara Nomor 47/Pdt.P/2012/PA.Tgrs. ${ }^{16}$ Dalam surat itu, Machica memohon agar hakim menyatakan bahwa anak laki-lakinya yang bernama Muhammad Iqbal Ramadhan adalah anak di luar perkawinan yang mempunyai hubungan perdata dengan Moerdiono sebagai ayahnya dan dengan keluarga Moerdiono. Oleh karena ternyata Moerdiono telah wafat pada hari Jumat tanggal 07 Oktober 2011, hakim juga dimohon untuk menetapkan bahwa Iqbal adalah ahli waris dari Moerdiono. ${ }^{17}$

${ }^{16}$ Sebenarnya, Machica pernah mengajukan gugatan perkara tahun 2008 dengan nomor 126/Pdt.G/2008/PA.Tgrs dan permohonan itsbat nikah dengan nomor 46/Pdt.P/2008/PA.Tgrs. Namun, langkah upaya hukum Machica tersebut terhalang dan tidak memperoleh peluang sama sekali untuk mendapatkan kepastian, kemanfaatan, dan keadilan bagi perkaranya, lantaran secara yuridis normatif Pasal 43 ayat (1) UU Perkawinan belum diujimaterikan ke MK. Pasca putusan MK Nomor 46/PUU-VIII/2010, Machica mengajukan kembali permohonan dan gugatan kasus yang sama, selain itsbat nikah, pada lembaga peradilan di lingkungan MA. Lihat Putusan MA No.465 K/AG/2012, hal 10.

${ }^{17}$ Sebelum memohon tentang hubungan perdata antara Iqbal dengan ayah biologisnya, terlebih dahulu Machica mengajukan petitum agar hakim menyatakan bahwa perkawinan antara Machica dengan Moerdiono yang dilangsungkan pada tanggal 20 Desember 1993 adalah perkawinan yang sah menurut hukum Islam, namun perkawinan tersebut sampai saat ini tidak dapat dicatat. Kemudian Hakim juga diminta menyatakan sebagai hukum bahwa Iqbal adalah 
Pada tanggal 17 April 2012, Majelis Hakim menetapkan bahwa permohonan tersebut tidak dapat diterima (niet ontvankelijk verklaar) sebab dinilai cacat formil. Dalil yang dikemukakan di antaranya adalah bahwa perkara "penetapan ayah biologis dari anak yang dilahirkan di luar perkawinan resmi dan akibatnya", apabila dilihat dari redaksi kalimatnya adalah penetapan atas permohonan (volunteer) Machica yang mengharapkan Moerdiono sebagai ayah biologis. Namun, dari segi kepentingannya, permohonan (volunteer) itu dinilai memiliki kepentingan dan persengketaan (disputed mattes) antara ibu dan anak yang dilahirkannya dengan calon ayah biologisnya atau keluarga ayah biologisnya. Dengan demikian, dalam permohonan (volunteer) tersebut dinilai mengandung cacat secara formil.

Tidak puas atas penetapan PA Tigaraksa, Machica kemudian mengajukan permohonan kasasi. Machica beralasan adalah bahwa dalam pertimbangan hukum PA Tigaraksa hanya didasarkan atas pemenuhan unsur kepastian hukum semata, tanpa mencakup unsur-unsur lainnya, yaitu kemanfaatan dan keadilan. PA Tigaraksa tidak melihat materi atau substansi permohonan dan tidak mencermati atas proses pencarian kepastian hukum yang dilakukan Machica sebelumnya. Demikian juga putusan MK Nomor 46/PUU-VIII/2010 tidak dijadikan bahan pertimbangan dalam keputusan. ${ }^{18}$

Pada tanggal 18 Desember 2012 melalui Putusan No. 465 K/AG/2012, MA menolak permohonan kasasi yang diajukan Machica. MA berpendapat bahwa alasan-alasan yang dikemukakan oleh Machica tidak dapat dibenarkan. Bahkan, MA menguatkan alasan yang dikemukakan PA Tigaraksa bahwa permohonan (volunteer) tersebut dinilai mengandung cacat secara formil, sehingga PA Tigaraksa selaku judex facti sudah tepat dalam menerapkan hukum. Dengan demikian, putusan judex facti dalam perkara yang diajukan Machica tidaklah bertentangan dengan hukum dan/atau UU. ${ }^{19}$

Pada kasus permohonan (volunteer) yang diajukan Machica pada PA Tigaraksa dan kasasi di MA ini, tidak dapat dijadikan obyek yang tepat untuk mengukur tingkat interkoneksi antara putusan MA dengan putusan MK. Sebab, permohonan (volunteer) yang diajukan Machica dinilai cacat secara formil, sehingga tidak dapat memasuki pada substansi materil hukum. Obyek interkoneksi antara putusan MA dengan putusan MK hanya dapat dilakukan dalam substansi materi putusan. Putusan MK Nomor 46/PUU-VIII/2010 membicarakan tentang materi perkara. Sementara putusan MA menyatakan bahwa permohonan (volunteer) yang diajukan Machica pada PA Tigaraksa dan kasasi di MA ini tidak memenuhi atau catat secara formal, sehingga tidak

anak yang dilahirkan dari perkawinan antara Machica dengan Moerdiono yang sah menurut hukum Islam namun tidak dapat dicatatkan itu. Lebih lengkap, baca Penetapan PA Tigaraksa Nomor: 47/Pdt.P/2012/PA.Tgrs., hal 11-12.

${ }^{18}$ Lihat Putusan MA No. 465 K/AG/2012, hal 9-10.

${ }^{19}$ Lebih lengkap baca Putusan MA No. 465 K/AG/2012 
memungkinkan substansi materi permohonannya dilakukan pemeriksaan dan putusan.

\section{Putusan atas Perkara Gugatan (Contentious) Machica pada Pengadilan Agama Jakarta Selatan, Pengadilan Tinggi Agama Jakarta dan Mahkamah Agung}

Pasca permohonan (volunteer) dinyatakan tidak dapat diterima, Machica mengajukan gugatan (contentious) pada Kepaniteraan PA Jakarta Selatan pada tanggal 28 Mei 2012 nomor register 1241/Pdt.G/2012/PA JS. Dalam gugatan itu, Machica memposisikan empat orang ahli waris dari Moerdiono sebagai pihak tergugat, yaitu istri almarhum sebagai Tergugat I, seorang anak perempuan dan seorang anak laki-laki dari almarhum sebagai Tergugat II dan Tergugat III serta seorang cucu dari almarhum sebagai Tergugat IV. Pengajuan gugatan terhadap ahli waris dalam perkara ini disebabkan oleh karena dalam lapangan hukum keluarga dan harta kekayaan, ahli waris merupakan subjek hukum yang bertindak mewakili kepentingan hukum pewaris.

Dalam proses perkara ini, setelah mengemukakan dalil (posita) atas gugatan di antaranya tentang sahnya perkawinan antara Machica dengan Moerdiono, Machica memohon Majelis Hakim untuk menjatuhkan Putusan Sela dan Putusan Akhir. Dalam Putusan Sela, Majelis Hakim dimohon untuk mengabulkan permohonan agar dilakukan tes DNA (Deoxyribonucleic acid) sehingga memerintahkan kepada Tergugat II, Tergugat III dan Iqbal untuk menjalani tes DNA tersebut. Sedangkan dalam Putusan Akhir, Majelis Hakim dimohon untuk mengabulkan seluruh gugatan Machica dan menyatakan bahwa perkawinan antara Machica dan Moerdiono adalah perkawinan yang sah menurut hukum Islam. Namun, perkawinan tersebut tidak dapat dicatatkan. Di samping itu, Majelis Hakim dimohon untuk menyatakan bahwa Iqbal adalah anak yang dilahirkan dari perkawinan yang sah. Dengan demikian, Majelis Hakim dimohon untuk menyatakan bahwa Iqbal adalah anak di luar perkawinan yang mempunyai hubungan perdata dengan Moerdiono sebagai ayahnya dan juga mempunyai hubungan perdata dengan keluarga Moerdiono, sehingga dimohon agar Iqbal adalah ahli waris dari Moerdiono.

Tergugat mengajukan eksepsi bahwa gugatan tersebut salah alamat, karena tuntutan Machica terhadap Moerdiono yang telah meninggal itu tidak dapat dibebankan kepada istri, anak dan cucunya. Para tergugat juga mengungkapkan bahwa perkawinan antara Machica dengan Moerdiono itu adalah perbuatan melanggar hukum, yakni melanggar pasal 9, pasal 4 dan pasal 2 ayat (2) UU Perkawinan serta pasal 6 ayat (2) Kompilasi Hukum Islam. Oleh karenanya, perkawinan itu harus dinyatakan "tidak sah dan tidak mempunyai kekuatan hukum" dan anak yang terlahir dari perkawinan tidak sah itu harus dianggap "bukan anak sah". 
Terkait dengan Putusan MK Nomor: 46/PUU-VIII/2010 tanggal 17 Februari 2012, para tergugat memberikan perlawanan bahwa menurut teori/doktrin dan juga praktek peradilan "Hakim tidak terikat dan tidak harus mengikuti kaidah hukum suatu Putusan MA atau MK, meskipun telah diikuti oleh hakim-hakim lain dalam berbagai putusan". Selain itu, para tergugat juga menyatakan bahwa sejalan dengan teori ilmu hukum "segala peraturan perundang-undangan, termasuk kaidah dalam Putusan MK tersebut tidak dapat diberlakukan secara surut, kecuali dinyatakan secara tegas dalam putusan". Dengan demikian, Putusan MK Nomor: 46/PUU-VIII/2010 tidak dapat diterapkan dalam perkara yang diajukan Machica, sebab Iqbal sebagai anak luar kawin sudah dilahirkan sebelum adanya Putusan MK tersebut.

Pada sisi lain, tergugat menegaskan bahwa gugatan (contentious) Machica merupakan suatu kezhaliman. Terhadap Tergugat I, Machica melakukan kezhaliman karena perkawinannya dengan Moerdiono tidak disertai izin berpoligami dari Tergugat I selaku isteri yang sah. Terhadap Tergugat II dan Tergugat III, Machica menuntut mereka supaya dipaksa untuk diambil sampelnya guna kepentingan Machica dan Iqbal sendiri. Dengan demikian, tidak ada alasan untuk memaksa Tergugat II dan Tergugat III melakukan tes DNA.

Setelah mengajukan replik oleh Machica dan duplik oleh para Tergugat, akhirnya Majelis Hakim PA Jakarta Selatan mengadili dan memutuskan bahwa dari empat gugatan yang diajukan Machica, hampir semuanya ditolak, dan hanya sebagian kecil yang dikabulkan. Berikut uraiannya.

Pertama, menurut Majelis Hakim gugatan Machica agar perkawinannya dengan Moerdiono dinyatakan sebagai perkawinan yang sah menurut hukum Islam, namun perkawinan tersebut tidak dapat dicatatkan tidaklah mempunyai alasan hukum, karenanya harus ditolak. Majelis Hakim berpendapat bahwa yang menentukan sahnya perkawinan adalah terpenuhinya syarat yang ditentukan oleh agama sebagaimana ketentuan pasal 2 ayat (1) UU Perkawinan, namun pasal 2 ayat (1) tidak dapat dipisahkan dengan ketentuan pasal 2 ayat (2), yaitu kewajiban administratif untuk mencatatkan perkawinan. Kewajiban administratif itu berfungsi untuk melindungi dan memenuhi hak asasi yang bersangkutan dan melindungi dari akibat hukum yang sangat luas, yakni di antaranya menjaga hak istri dan hak anak mereka. Dengan dicatatkannya suatu perkawinan, hak-hak yang timbul dari suatu perkawinan dapat dilindungi oleh negara. Oleh karena pentingnya fungsi pencatatan tersebut, pasal 6 Kompilasi Hukum Islam menegaskan bahwa perkawinan yang dilakukan di luar pengawasan Pegawai Pencatat Nikah tidak mempunyai kekuatan hukum.

Selanjutnya Majelis Hakim memaparkan bahwa kasus perkawinan yang sudah memenuhi rukun dan syarat menurut hukum Islam tetapi tidak dapat dibuktikan dengan akta nikah, dapat diajukan itsbat nikah ke PA. Itsbat nikah yang dapat diajukan ke PA itu terbatas dengan perkawinan yang dilakukan oleh 
mereka yang tidak mempunyai halangan perkawinan menurut UU Perkawinan. Hal ini didasarkan atas pasal 7 ayat (2) dan (3) Kompilasi Hukum Islam. Dalam konteks ini, terhadap perkawinan Machica dengan Moerdiono tidak dapat dilakukan itsbat nikah, sebab terdapat halangan perkawinan, yaitu tidak terpenuhinya pasal 3 dan pasal 4 UU Perkawinan tentang izin poligami dari pengadilan.

Kedua, dikarenakan perkawinan Machica dengan Moerdiono tidak dapat diitsbatkan, maka sebagai akibat hukumnya, status Iqbal sebagai anak yang lahir dari perkawinan yang tidak dapat diitsbatkan itu juga tidak dapat dinyatakan sebagai anak sah. Pasal 42 UU Perkawinan menyatakan bahwa anak yang sah adalah anak yang dilahirkan dalam atau sebagai akibat perkawinan yang sah. Termasuk anak sah juga adalah anak yang lahir dari perkawinan yang telah diitsbatkan. Dengan demikian, gugatan Machica terkait status Iqbal agar dinyatakan sebagai anak yang dilahirkan dari perkawinan yang sah namun tidak dapat dicatatkan juga ditolak oleh Majelis Hakim.

Ketiga, implikasi hukum atas tidak dapat diitsbatkannya perkawinan Machica dengan Moerdiono adalah Majelis Hakim menolak gugatan Machica yang mengharapkan agar Iqbal dinyatakan sebagai ahli waris dari Moerdiono. Menurut Majelis Hakim, anak yang dapat ditetapkan sebagai ahli waris adalah anak yang sah atau anak yang lahir dalam perkawinan yang telah diitsbatkan oleh Pengadilan.

Keempat, gugatan Machica agar Iqbal dinyatakan sebagai anak di luar perkawinan yang mempunyai hubungan perdata dengan Moerdiono sebagai ayahnya dan juga mempunyai hubungan perdata dengan keluarga Moerdiono hanya sebagian yang dikabulkan oleh Majelis Hakim, sedangkan yang sebagiannya lagi ditolak. Majelis Hakim mengabulkan gugatan Machica agar Iqbal dinyatakan sebagai anak yang lahir di luar perkawinan dari Machica dan Moerdiono, tetapi mereka menolak gugatan Machica sepanjang mengenai Iqbal dinyatakan mempunyai hubungan perdata dengan Moerdiono dan keluarganya.

Untuk membuktikan Iqbal adalah anak hasil hubungan biologis Machica dengan Moerdiono, sebagai bukti permulaan Majelis Hakim secara ex officio memerintahkan kepada Machica untuk melakukan sumpah suppletoir (sumpah pelengkap/tambahan) guna melengkapi keterangan dua saksi yang dihadirkan Machica. Sumpah tersebut harus dilakukan sebagai solusi pembuktian, karena Tergugat II dan Tergugat III menolak melakukan tes DNA sesuai Putusan Sela Majelis Hakim pada tanggal 7 November 2012. Sumpah suppletoir itu dilaksanakan berdasarkan ketentuan pasal 155 HIR dan pasal 1940 KUHPerdata. Dengan sumpah tersebut, Iqbal sebagai anak hasil hubungan biologis Machica dengan Moerdiono telah terbukti. Namun, oleh karena perkawinan mereka tidak dapat diitsbatkan, maka Iqbal termasuk anak yang lahir di luar perkawinan. 
Lebih lanjut Majelis Hakim berargumentasi dengan pasal 56 ayat (1) UU Nomor 39 Tahun 1999 tentang Hak Asasi Manusia, bahwa "setiap anak berhak untuk mengetahui siapa orang tuanya..." dan pasal 7 UU Nomor 23 Tahun 2002 tentang Perlindungan Anak, bahwa "setiap anak berhak untuk mengetahui orang tuanya...". Dari kedua UU tersebut dapat dipahami bahwa hak anak untuk mengetahui orang tuanya (ayah dan ibunya) adalah hak dasar anak yang harus dipenuhi, dalam hal ini melalui Pengadilan. Pembiaran terhadap hak anak yang ingin mendapatkan kepastian tentang siapa orang tuanya adalah suatu pelanggaran terhadap hak asasi anak. Tidak hanya itu, keberadaan anak yang tidak mengetahui siapa ayahnya seperti dalam perkara ini akan menjadi beban psikologis bagi anak yang bersangkutan. Oleh karena itu, sungguh tidak adil apabila beban psikologis tersebut harus dipikul anak, sehingga akhirnya Majelis Hakim mengabulkan gugatan Machica bahwa Iqbal dinyatakan sebagai anak yang dilahirkan di luar perkawinan dari Machica dan Moerdiono.

Hanya saja, terhadap gugatan Machica agar Iqbal dinyatakan mempunyai hubungan perdata dengan Moerdiono dan keluarganya berdasarkan Putusan MK Nomor 46/PUU-VIII/2010 yang mengubah pasal 43 ayat (1) UU Perkawinan oleh Majelis Hakim dinilai tidak beralasan hukum, karenanya harus ditolak. Menurut Majelis Hakim, pada dasarnya setiap UU, termasuk Putusan MK Nomor 46/PUU-VIII/2010 tidak berlaku surut (asas non retroaktif). Asas non retroaktif hanya boleh dilanggar apabila dalam salah satu pasal UU itu disebutkan bahwa UU berlaku surut. Dalam kaitan asas non retroaktif ini Majelis Hakim mempertimbangan hal-hal sebagai berikut:

a. Pendapat saksi ahli yang diajukan Tergugat, Dr. Andi Irman Putra Sidin, SH.,MH. Menurut beliau, Putusan MK adalah mengikat sejak berkekuatan hukum tetap, tetapi tidak berlaku surut (retroaktif), kecuali ada klausul yang memberlakukan secara retroaktif. Apabila berlaku surut maka akan terjadi kekacauan dalam hubungan perdata. Irman menganalogikan seseorang keluar rumah dan tersenyum dengan seorang wanita di jalan, lalu wanita tersebut membalas senyumnya. Tahun berikutnya ada aturan yang melarang seseorang senyum dengan wanita lain, lalu dituntut dengan hukum yang baru itu. Tentu dalam hal ini akan terjadi kekacauan, karena perbuatan yang pada waktu melakukannya dibolehkan, beberapa tahun kemudian terdapat larangan karena ada aturan baru. Larangan memberlakukan hukum secara retroaktif sejalan dengan pasal 28i UUD NRI 1945, meskipun pasal 28i tersebut dalam konteks hukum pidana, tetapi menurut Irman berlaku juga dalam hukum perdata. $^{20}$

${ }^{20}$ Untuk lebih lengkapnya, baca Putusan PA Jakarta Selatan Nomor 1241/Pdt.G/2012/PA JS., hal 39-40. 
b. Pendapat Prof. Purnadi Purbacaraka dan Prof. Dr. Soerjono Soekanto yang mengartikan pasal $2 \mathrm{AB}$ dalam hubungannya dengan asas non retroaktif bahwa "UU hanya boleh dipergunakan terhadap peristiwa yang disebutkan dalam UU dan terjadi setelah UU itu dinyatakan berlaku". Secara a contrario dapat dipahami bahwa UU tidak boleh digunakan terhadap peristiwa yang disebut dalam UU yang terjadi sebelum UU tersebut berlaku.

c. Secara sosiologis, pemberlakukan retroaktif suatu aturan secara umum akan mengakibatkan kekacauan hukum dan ketidakpastian hukum, bahkan melanggar hak asasi karena perbuatan yang dahulunya tidak bisa digugat, kemudian beberapa tahun kemudian berdasarkan atauran baru dapat digugat. Hal ini akan berdampak luas karena putusan MK bersifat Erga Omnes, yaitu berlaku bagi siapa saja, tidak hanya bagi pihak yang mengajukan perkara.

Dengan demikian, Majelis Hakim PA Jakarta Selatan berpendapat bahwa sebenarnya Putusan MK Nomor 46/PUU-VIII/2010 yang diucapkan dalam sidang pleno terbuka untuk umum tanggal 17 Februari 2012 itu sudah berlaku sejak dimuat dalam berita negara, yaitu dalam jangka waktu paling lambat 30 hari kerja sejak putusan diucapkan. ${ }^{21}$ Hanya saja, dikarenakan pada putusan itu tidak terdapat klausul yang dapat dimaknai berlaku surut (retroaktif), maka putusan itu tidak dapat dipakai sebagai landasan hukum dalam mengabulkan gugatan Machica, terutama tentang adanya hubungan keperdataan antara Iqbal dengan Moerdiono. Sebab, Iqbal lahir pada tanggal 5 Februari 1996 sementara Putusan MK Nomor 46/PUU-VIII/2010 adalah tanggal 17 Februari 2012.

Tidak puas atas Putusan PA Jakarta Selatan, Machica kemudian mengajukan permohonan banding dan didaftar di Kepaniteraan PTA Jakarta dalam register perkara banding Nomor 75/Pdt.G/2013/PTA.JK tanggal 24 Juli 2013. Ternyata, Majelis Hakim PTA Jakarta menguatkan Putusan PA Jakarta Selatan, dengan memperbaiki amar putusan tentang eksepsi.

Machica tidak puas dengan putusan tingkat banding itu sehingga mengajukan kasasi dengan dua alasan. Pertama, putusan judex facti mengandung kesesatan dalam mengkonstatir sahnya perkawinan menurut UU Perkawinan, karena dalam menilai sah tidaknya perkawinan mendasarkan pada ketentuan pasal 2 ayat (1) dan ayat (2) UU Perkawinan. Padahal, syarat sah perkawinan itu adalah apabila dilakukan menurut hukum agama dan kepercayaan yang dianut seperti yg dimuat dalam pasal 2 ayat (1) UU Perkawinan. Sedangkan pencatatan

${ }^{21}$ Pasal 47 UU MK Nomor 24 Tahun 2003 menjelaskan "Putusan MK memperoleh kekuatan hukum tetap sejak selesai diucapkan dalam sidang pleno terbuka untuk umum." Kemudian pada pasal 57 ayat (3) UU yang sama disebutkan "Putusan MK yang mengabulkan permohonan wajib dimuat dalam berita negara dalam jangka waktu paling lambat 30 hari kerja sejak putusan diucapkan." Ketentuan tersebut menunjukkan bahwa putusan MK berlaku setelah dimuat dalam berita negara. 
perkawinan yang dimaksud dalam pasal 2 ayat (2) itu bukanlah norma hukum yang bersifat mengikat. Kedua, Putusan MK Nomor 46/PUU-VIII/2010 dapat berlaku surut (retroaktif). Larangan norma hukum berlaku surut hanya dikenal dalam ranah hukum pidana. Untuk menentukan apakah suatu norma hukum dapat berlaku surut atau tidak dalam hukum perdata adalah dilihat dari pihak yang berkepentingan. Artinya, pemberlakuan suatu peraturan yang berlaku mundur tidak boleh merugikan pihak atau orang yang terkena peraturan tersebut, termasuk pelanggaran terhadap hak asasi manusia atau kepentingan pribadinya.

Melalui Putusan No. $329 \mathrm{~K} / \mathrm{Ag} / 2014$, MA menyatakan membatalkan Putusan PTA Jakarta Nomor 75/Pdt.G/2013/PTA.JK dan selanjutnya mengadili sendiri, yang amar putusannya "menolak eksepsi para Tergugat/para Terbanding" dan "menolak gugatan Machica seluruhnya". MA berpendapat PTA Jakarta dan PA Jakarta Selatan keliru dalam mempertimbangkan dan memutus perkara tersebut, dengan penjelasan sebagai berikut:

a. Putusan PTA Jakarta yang menguatkan Putusan PA Jakarta Selatan sudah tepat dan benar dalam hal menolak gugatan Machica tentang pengesahan perkawinannya dengan Moerdiono. Menurut MA, gugatan Machica terkait pengesahan perkawinan tersebut tidak termasuk kewenangan PA. Sebab, merujuk Penjelasan pasal 49 ayat (2) angka 22 UU Peradilan Agama Nomor 7 Tahun 1989 yang telah diubah dengan UU Nomor 3 tahun 2006 hanya memberi kewenangan untuk perkawinan yang terjadi sebelum UU Nomor 1 Tahun 1974 dan dijalankan menurut peraturan yang lain.

b. Dengan ditolaknya tuntutan pengesahan perkawinan, maka tuntutan Machica agar Iqbal dinyatakan sebagai anak yang sah juga harus ditolak. Sebab, pasal 99 Kompilasi Hukum Islam jo. pasal 42 UU Perkawinan menegaskan "anak yang sah adalah anak yang dilahirkan dalam atau sebagai akibat perkawinan yang sah". Berkaitan dengan ini, MA berpendapat bahwa tuntutan Machica agar Iqbal dinyatakan sebagai "anak yang dilahirkan dari perkawinan sah" menurut hukum Islam adalah bertentangan (kontradiksi) dengan tuntutan berikutnya agar Iqbal dinyatakan sebagai "anak di luar perkawinan" yang mempunyai hubungan perdata dengan Moerdiono sebagai ayahnya.

c. Putusan PTA Jakarta dan PA Jakarta Selatan yang mengabulkan tuntutan Machica tentang status anak di luar kawin adalah putusan yang telah menyimpang dari tugas dan wewenang hakim pada peradilan agama. MA berpendapat bahwa mengadili tuntutan untuk dinyatakan sebagai anak di luar perkawinan tidaklah termasuk kewenangan PA. Dalam Penjelasan pasal 49 ayat (2) UU Peradilan Agama disebutkan bahwa 
kewenangan PA adalah menyatakan sah tidaknya seorang anak, bukan menyatakannya sebagai anak di luar perkawinan.

\section{Interkoneksi dan Implementasi Putusan MK dalam Putusan di Lingkungan MA}

MA dan MK merupakan lembaga penyelenggara kekuasaan kehakiman yang memiliki otoritas dalam memfasilitasi mewujudkan keadilan. Dalam konteks mewujudkan keadilan, baik MA maupun MK tentu memiliki proporsinya masing-masing. ${ }^{22}$ Prof. Jimly Assshiddiqie menyebutkan bahwa MA pada hakikatnya adalah court of justise, yakni mengadili ketidakadilan untuk mewujudkan keadilan, sedangkan MK adalah court of law, yakni mengadili sistem hukum dan sistem keadilan itu sendiri. ${ }^{23}$ Oleh karenanya, interkoneksi antara keduanya tidak diarahkan dalam pendekatan secara struktural, tetapi lebih diarahkan pada kepatuhan sebuah lembaga peradilan yang berada di naungan MA dalam memperlakukan putusan yang telah dihasilkan oleh MK.

MK memiliki putusan yang bersifat final dan mengikat (final and binding), yakni langsung memperoleh kekuatan hukum tetap dan mengikat serta dapat dieksekusi sejak diucapkan dalam sidang terbuka untuk umum, sehingga tidak ada upaya hukum untuk mengubah putusan tersebut. ${ }^{24}$ Di samping itu, putusan MK juga bersifat erga omnes, yakni bersifat mengikat dan harus dipatuhi oleh setiap warga negara, tidak hanya oleh pihak yang berperkara saja, karena menyangkut kepentingan umum. Bahkan, status putusan MK dianggap sederajat dengan UU. Oleh karenanya, hakim pada lembaga peradilan dalam naungan MA patut memposisikan putusan MK sebagai dasar pertimbangannya.

Dalam konteks kasus yang diajukan Machica, putusan MK Nomor 46/PUU-VIII/2010 ternyata dalam implementasinya di lingkungan lembaga peradilan MA, baik di tingkat PA, PTA maupun MA tidak selalu dijadikan dasar pertimbangan dalam putusan majelis hakim. Jika melihat putusan Majelis Hakim PA Jakarta Selatan dan PTA Jakarta dengan putusan Mejelis Hakim MA maka terdapat perbedaan. Majelis Hakim PA Jakarta Selatan dan PTA Jakarta mempertimbangkan Putusan MK Nomor 46/PUU-VIII/2010 dalam putusan mereka. Bahkan, putusan MK tersebut tidak hanya dijadikan sebagai dasar pertimbangan, tetapi juga dibahas lebih detil dan diberikan interpretasi.

\footnotetext{
${ }^{22}$ Baik MA maupun MK, masing-masing berdiri sendiri. Antara yang satu dengan yang lain terpisah dalam segala hal. Bukan hanya terpisah dan berbeda dari segi yurisdiksi saja. Antara yang satu dengan yang lain, tidak saling subordinasi. Susunan organisasinya juga terpisah dan berdiri sendiri. M. Yahya Harahap, Kekuasaan MA: Pemeriksaan Kasasi dan Peninjauan Kembali Perkara Perdata, (Jakarta: Sinar Grafika, 2008), h. 16-17.

${ }^{23}$ Jimly Asshiddiqie, "Kedudukan Mahkamah Konstitusi dalam Struktur Ketatanegaraan Indonesia", makalah dipresentasikan pada kuliah umum di Fakultas Hukum Universitas Sebelas Maret Surakarta, Kamis, 2 September 2004.

24 Penjelasan Pasal 10 ayat [1] UU 8/2011 tentang MK.
} 
Hal ini berbeda dengan MA dalam putusan kasasinya. Bahkan, dalam putusan MA tidak menyinggung sama sekali atas Putusan MK tersebut. Kenyataan ini menunjukkan bahwa Majelis Hakim MA cenderung tidak mempergunakan putusan MK Nomor 46/PUU-VIII/2010 sebagai dasar pertimbangan hukumnya. Padahal, putusan MK tersebut jelas-jelas hadir atas perkara yang diajukan Machica. Bahkan, dalam putusan kasasinya, MA menolak eksepsi para tergugat dan menolak gugatan penggugat seluruhnya, ${ }^{25}$ sehingga putusan PA Jakarta Selatan dan PTA Jakarta dibatalkan dan tertolaknya semua gugatan Machicha.

Putusan kasasi ini menunjukkan bahwa MA membuat keputusan yang bertolak belakang dengan putusan MK. MA tidak mengakui status anak di luar nikah sehingga majelis hakim dinyatakan menyimpang. Meski dalam putusan MK Nomor 46/PUU-VIII/2010 dinyatakan secara tegas bahwa "Anak yang dilahirkan di luar perkawinan mempunyai hubungan perdata dengan ibunya dan keluarga ibunya serta dengan laki-laki sebagai ayahnya yang dapat dibuktikan berdasarkan ilmu pengetahuan dan teknologi dan/atau alat bukti lain menurut hukum mempunyai hubungan darah termasuk hubungan perdata dengan keluarga ayahnya", MA tetap mengabaikannya, bahkan status anak di luar nikah harus dikembalikan pada kesepakatan ulama dan cendekiawan muslim Indonesia yang telah tertuang pada Kompilasi Hukum Islam bidang hukum perkawinan.

Pada perspektif tertentu, putusan kasasi MA dapat dibenarkan. Putusan MK yang membatalkan UU Nomor 1 Tahun 1974 Pasal (43) sesungguhnya berkonsekwensi atas kekosongan hukum pada pasal tersebut. Pasal yang dianulir MK ini menjadi tidak berlaku yang kemudian diperlukan upaya "revisi terbatas" untuk melahirkan pasal yang baru. Namun, hal ini tidak pernah terjadi. Bahkan, MK melahirkan sebuah norma hukum yang baru sebagaimana dalam putusannya itu. Dalam perspektif ini, MK dinilai telah melakukan sebuah tindakan yang melampaui batas kewenangannya, yakni tidak hanya sebatas menguji sebuah UU atas UUD, namun juga memberikan norma hukum yang baru sama sekali.

Menurut penulis, interkoneksi antara lembaga peradilan di bawah naungan MA baik PA maupun PTA dengan MK dalam putusan hukumnya cukup baik, namun tidak demikian halnya dengan MA. Baik PA maupun PTA, keduanya cenderung telah mendudukkan putusan MK sebagai putusan yang final dan mengikat (final and binding). Namun, MA tidak mendudukkan putusan MK tersebut sebagai putusan yang final dan mengikat. Dalam perkara Machica, MA cenderung mengabaikan putusan MK dan mengembalikannya pada Kompilasi Hukum Islam. Atas kenyataan ini, sebagai lembaga yudikatif, hubungan antara MK dengan MA, terutama ketika MA menetapkan putusan pasca terbitnya putusan MK, belum menunjukkan hubungan yang semestinya.

${ }^{25}$ Lihat putusan kasasi MA, hal. 19. 
Hal ini terjadi dimungkinkan oleh karena terdapatnya pemahaman yang beragam antara MK dengan MA. Bagi MK status anak di luar nikah mesti mendapatkan kedudukan yang jelas sehingga perlu mendapatkan ketegasan hukum. Sementara MA lebih cenderung mendudukkan status anak di luar nikah itu di luar domain negara sehingga PA dan PTA tidak dapat memberikan keputusan hukum. Keputusan mengenai anak di luar nikah menjadi domain agama sehingga statusnya dikembalikan pada hukum agama, sebagaimana yang telah dirumuskan dalam Kompilasi Hukum Islam di Indonesia.

Pada sisi lain, putusan MK Nomor 46/PUU-VIII/2010 itu cenderung terdapat pemahaman yang beragam, apakah putusan tersebut berlaku surut atau tidak. Bagi pihak penggugat, putusan tersebut dapat berlaku surut, sebab putusan ini menyangkut hukum perdata. Putusan dinyatakan tidak berlaku surut jika menyangkut hukum pidana. Untuk menentukan apakah suatu putusan atau norma hukum dapat berlaku surut atau tidak dalam hukum perdata adalah dilihat dari pihak yang berkepentingan. Oleh karenanya, bagi Machica sebagai pihak penggugat, putusan MK tersebut dapat menjadi landasan majelis hakim untuk mengabulkan gugatannya. Akan tetapi, yang terjadi justeru sebaliknya. Majelis hakim, baik di PA Jakarta Selatan maupun PTA Jakarta, mendudukkan putusan MK ini tidak berlaku surut. Menurut Majelis Hakim, pada dasarnya setiap UU, termasuk Putusan MK ini tidak berlaku surut (asas non retroaktif), kecuali ada klausul yang memberlakukan secara retroaktif. Di sisi lain, putusan MK itu bersifat erga omnes, berlaku bagi siapa saja, tidak hanya bagi pihak yang mengajukan perkara. Apabila berlaku surut maka akan terjadi kekacauan dalam hubungan perdata.

Dalam konteks interkoneksi antara MK dengan lembaga peradilan di tingkat PA dan PTA, sebagaimana tergambar dalam uraian di atas, itu menunjukkan relasi yang cukup baik. Baik PA Jakarta Selatan maupun PTA Jakarta, keduanya menggunakan putusan MK sebagai dasar pertimbangan dalam memutuskan perkara yang dihadapinya.

Sebagaimana diketahui, setidaknya terdapat 2 (dua) aliran besar dalam penerapan hukum, yakni sistem civil law dan sistem common law. Sistem civil law bercirikan hakim hanya menerapkan isi rumusan hukum tertulis. Jika terjadi pertentangan antara UU dengan yurisprudensi maka yang dimenangkan adalah UU. Sistem hukum ini biasanya berlaku di Eropa Kontinental, dan dulu diterapkan di Indonesia. Adapun sistem common law mengakui bahwa putusan pengadilan adalah hukum. Sumber hukum dalam sistem ini ialah putusan hakim atau pengadilan. Oleh karenanya, hakim disebut sebagai pencipta hukum (judge made law). Jika terdapat pertentangan antara UU dengan yurisprudensi, maka yurisprudensilah yang dimenangkan. Sistem ini biasa diterapkan di negaranegara Anglo Saxon. 
Melihat temuan di atas, dalam konteks penerapan hukum di Indonesia agaknya terdapat pergeseran. Jika dahulu Indonesia diklaim sebagai pengikut sistem civil law, yakni praktek penerapan hukum di Indonesia mengikuti tidak hanya perundang-undangan, tetapi juga hukum Islam, dan yurisprudensi, maka kini Indonesia cenderung menerapkan sistem hukum campuran (mix legal system) antara sistem civil law dan sistem common law. Dalam konteks kasus Machica, putusan di tingkat PA dan PTA menggunakan sistem civil law, yakni berpegang pada putusan MK, sebagai putusan yang sederajat dengan UU dan bersifat erga omnes. Sementara di tingkat MA, putusan kasasi kasus Machica berada di tangan hakim sebagai penentunya, bukan pada putusan MK atau teks UU.

Pergeseran penerapan hukum di Indonesia dari sistem civil law menuju sistem hukum campuran (mix legal system) antara sistem civil law dengan sistem common law, itu menunjukkan bahwa hukum tidak dipahami secara kaku dan sempit. Dalam konteks ini, merujuk hipotesis Jimly Ash-Shiddieqy, hakim MA tampaknya bukan lagi berperan sebagai la bouche de la loi (corong UU) tetapi memerankan diri sebagai the living interpretator (penerjemah hidup) yang berusaha menangkap semangat keadilan dalam kasus yang dihadapi. Dalam pemahaman lain, hakim bukan hanya memutuskan suatu perkara berdasarkan keadilan-prosedural, tetapi juga keadilan-substantif. ${ }^{26}$

\section{Kesimpulan}

Terdapat interkoneksi antara MK dengan MA dalam putusan hukum yang terkait dengan kasus Machica. Namun, interkoneksi itu belum menunjukkan hubungan yang semestinya. MA dalam putusan kasasinya tidak menjadikan putusan MK Nomor 46/PUU-VIII/2010 sebagai bahan pertimbangan, bahkan justeru mengabaikannya. Terkait dengan ini, menurut penulis, perlu dilakukan langkah konkret upaya untuk menegakkan putusan MK sehingga dapat diimplementasikan dalam putusan MA. Upaya ini bagian yang perlu disuarakan oleh semua stakeholders yang terkait dengan upaya penegakan hukum, baik kalangan pemerintah, legislatif maupun masyarakat untuk mendorong supremasi hukum dan tata kelola kelembagaan negara, dalam hal ini yudikatif. Selain itu, perlu adanya penelitian lanjutan, misalnya putusan MK Nomor 46/PUU-VIII/2010 yang diimplementasikan dalam putusan lembaga peradilan di bawah MA terhadap kasus-kasus pasca efektifnya putusan MK itu. Jika kasus Machica dipandang sebagai kasus yang tidak dapat dikaitkan dengan

${ }^{26}$ Lebih lanjut baca Jimly Asshiddiqie, Pokok-Pokok Hukum Tata Negara Indonesia Pasca Reformasi, (Jakarta: Bhuana Ilmu Populer, 2007), h. 305-306. Baca juga “Manifesto Keadilan Substantif oleh Mahkamah Konstitusi; Sebuah Paradoks (Kajian atas Beberapa Putusan MK dalam Perkara Pengujian Undang-undang", dalam https://ridhme.wordpress.com/2012/07/02/manifestokeadilan-substantif-oleh-mahkamah-konstitusi-sebuah-paradoks-kajian-atas-beberapa-putusanmk-dalam-perkara-pengujian-undang-undang/, diakses pada 27 Maret 2015. 
putusan $\mathrm{MK}$, karena terjadinya sebelum kelahiran putusan $\mathrm{MK}$, maka yang dijadikan obyek penelitian lanjutan adalah kasus-kasus yang terjadi pasca putusan MK tersebut.

\section{Pustaka Acuan}

Anonim, "Putusan MK Bersifat Erga Omnes" dalam http://www.mahkamahkonstitusi.go. $\quad$ id/index.php?page=website. BeritaInternal Lengkap\&id=4044, diunduh pada 27 Maret 2015

-------, "Analisa Yuridis Putusan Ultra Petita Mahkamah Konstitusi dalam Menguji Undang-Undang Terhadap Undang-Undang Dasar", dalam https://ramsespurba. wordpress.com/2013/07/11/analisa-yuridis-putusanultra-petita-mahkamah-konstitusi-dalam/, diunduh pada 27 Maret 2015.

-------, “Manifesto Keadilan Substantif oleh Mahkamah Konstitusi; Sebuah Paradoks (Kajian atas Beberapa Putusan MK dalam Perkara Pengujian Undang-undang", $\quad$ dalam https://ridhme.wordpress.com/2012/07/02/manifesto-keadilan-substantifoleh-mahkamah-konstitusi-sebuah-paradoks-kajian-atas-beberapaputusan-mk-dalam-perkara-pengujian-undang-undang/, diakses pada 27 Maret 2015.

Asshiddiqie, Jimly, "Kedudukan Mahkamah Konstitusi dalam Struktur Ketatanegaraan Indonesia", Makalah disampaikan dalam Seminar di UNS, pada Kamis, 2 September 2004, diunduh dari www.hukumonline.com tanggal 07 Februari 2015.

------, Pokok-Pokok Hukum Tata Negara Indonesia Pasca Reformasi, (Jakarta: Bhuana Ilmu Populer, 2007).

Estiko, Didit Hariadi dan Suhartono (ED), Mahkamah Konstitusi: Lembaga Negara Baru Pengawal Konstitusi, (Jakarta: P31 Sekretariat Jenderal DPR RI, Agarino Abadi, 2003).

Halim, A. Ridwan, Pengantar Tata Hukum Indonesia dalam Tanya Jawab, (Jakarta: Ghalia Indonesia, 1985).

Hamzah, Andi, Hukum Acara Pidana Indonesia, (Jakarta: Sapta Artha Jaya, 1996).

Harahap, M. Yahya, Hukum Acara Perdata tentang Gugatan, Persidangan, Penyitaan, Pembuktian, dan Putusan Pengadilan, (Jakarta: Sinar Grafika, 2008).

------, Kekuasaan Mahkamah Agung: Pemeriksaan Kasasi dan Peninjauan Kembali Perkara Perdata, (Jakarta: Sinar Grafika, 2008).

Mahkamah Agung Republik Indonesia, Laporan Tahunan 2010, Februari 2011. 
Siahaan, Maruar, Hukum Acara Mahkamah Konstitusi Republik Indonesia, (Jakarta: Sekretariat Jenderal dan Kepaniteraan MK RI, 2006).

Sutiyoso, Bambang dan Sri Hastuti Puspitasari, Aspek-Aspek Perkembangan Kekuasaan Kehakiman di Indonesia, (Yogyakarta: UII Press, 2005).

Sutiyoso, Bambang, "Pembentukan Mahkamah Konstitusi Sebagai Pelaku Kekuasaan Kehakiman di Indonesia", dalam Jurnal Konstitusi, Vol. 7, No. 6, Desember 2010. 
Interkoneksi Mahkamah Konstitusi Dengan Mahkamah Agung 


\title{
Perempuan Dalam Penegakan Hukum di Indonesia; Studi Peran Perempuan di Pengadilan Agama DKI Jakarta*
}

\author{
(Women in Law Enforcement in Indonesia; Study of the Role of Women in \\ DKI Jakarta Religious Court)
}

\author{
Kamarusdiana, ${ }^{1}$ Sri Hidayati ${ }^{2}$ \\ Universitas Islam Negeri Syarif Hidayatullah Jakarta, Indonesia
}

doi $10.15408 /$ sjsbs.v5i1.7905

\begin{abstract}
:
The purpose of this study was to find out the position of women in law enforcement in Indonesia and the role of women in the Jakarta Special Capital District Religion Court. This research is a normative juridical study with a normative juridical approach and empirical juridical. Based on the results of the study, two conclusions were obtained. First, that the position of women in the realm of law enforcement in Indonesia, especially in the Religious Courts, is the same as that of men. Second, the role of women in the Special Capital District of Jakarta in accordance with Law Number 50 of 2009 is the same as the role of men in terms of the profession of a judge, clerk and bailiff even when being a structural officer.
\end{abstract}

Keywords: Women, law enforcement, role

\begin{abstract}
Abstrak:
Tujuan dari penelitian ini adalah untuk mengetahui kedudukan Perempuan dalam penegakan hukum di Indonesia dan peranan Perempuan di Pengadilan Agama daerah Khusus Ibukota Jakarta. Penelitian ini merupakan suatu penelitian yuridis normatif dengan pendekatan yuridis normatif dan yuridis empirik. Berdasarkan hasil penelitian, didapat dua kesimpulan. Pertama bahwa kedudukan wanita dalam ranah penegakan hukum di Indonesia khususnya di Pengadilan Agama sudah sama dengan laki. Kedua, peran wanita di Pengadilan Agama daerah Khusus Ibukota Jakarta sesuai dengan Undang-Undang Nomor 50 tahun 2009 sudah sama dengan peran laki-laki dalam hal profesi seorang hakim, panitera maupun juru sita bahkan ketika menjadi pejabat di struktural.
\end{abstract}

Kata kunci: Perempuan, penegakan hukum, peran.

* Diterima tanggal naskah diterima: 12 Desember 2016, direvisi: 22 Maret 2017, disetujui untuk terbit: 20 April 2017.

${ }^{1}$ Kamarusdiana adalah Doktor Bidang Hukum dan Dosen Tetap Fakultas Syariah dan Hukum UIN Syarif Hidayatullah Jakarta email: kamarusdiana@uinjkt.ac.id.

2 Sri Hidayati adalah Dosen Tetap Fakultas Syariah dan Hukum UIN Syarif Hidayatullah Jakarta email: sri.hidayati@uinjkt.ac.id. 


\section{Pendahuluan}

Pada abad pertengahan sampai dengan pernulaan abad ke-9 kaum wanita di dunia tidak mendapat kedudukan, hak yang layak yang dilindungi oleh undang-undang dan hukum.Dimana kaum wanita disamakan dengan barang-barang yang hanya milik kaum lelaki dan juga juga hanya sebagai pemuas nafsunya belaka.Pendidikan kaum wanita hanya terbatas kepada hal-hal yang berhubungan dengan kerumahtangaan seperti mengurus rumah tangga, memasak, menjahit dan mengasuh anak. ${ }^{3}$ Akan tetapi pada zaman modern ini, kaum wanita telah jauh melangkah ke depan ${ }^{4}$. Dimana kaum wanita pada zaman modern ini, kaum wanita telah jauh melangkah kedepan. Di mana kaum wanita pada zaman modern ini, kaum wanita telah mendapat kedudukan dan hak-hak yang layak sebagai umat manusia yang sama derajat dan martabatnya dengan kaum pria. Di Indonesia setelah proklamasi kemerdekaan Republik Indonesia tanggal 17 Agustus 1945, kaum wanita telah ditegaskan bahwa kedudukan dan haknya sama dengan kaum pria, baik sebagai penduduk maupun sebagai warga Negara RI. ${ }^{5}$

Kedudukan perempuan Indonesia dalam rangka turut serta mengisi gerak pembangunan telah pula ditegaskan dalam GBHN pada zaman orde baru dahulu yaitu pembangunan menyeluruh mensyaratkan ikut sertanya pria maupun wanita secara maksimal disegala bidang. Dalam rangka ini wanita mempunai hak, kewajiban dan kesempatan yang sama dengan pria untuk ikut serta dalam segala bidang kegiatan pembangunan ${ }^{6}$. Jelas bahwa ikut sertanya kaum wanita dalam proses pembangunan dan pembinaan bangsa ini mutlak adanya tanpa mengurani peranan wanita menurut kodratnya sebagai pembina rumah tangga ${ }^{7}$

Perjuangan Emansipasi wanita setelah kemerdekaan, telah dituangkan dalam beraneka bentuk, baik berupa perundang-undangan maupun yurisprudensi Mahkamah Agung dan hal ini membuktikan bahwa kedudukan kaum wanita dimata hukum Indonesia dewasa ini menunjukan kemajuan yang sangat pesat dan positif. ${ }^{8}$ Kepemimpinan perempuan termasuk kedudukannya sebagai hakim dalam Islam menjadi hal yang debatable karena adanya perbedaan pemahaman terhadap QS al- Nisa: 34 dan sebuah hadis yang meragukan kepemimpinan perempuan. Ayat 34 surat al- Nisa ini menggunakan

3 Budi Munawar Rahman, Sekularis, Liberalis, dan Plularisme, Islam Progresif dan Perkembangan Diskursusnya, Jakarta, PT. Gramedia, 2010, h.11

4 Dahlia Lubis, Konsep Emansipasi Wanita Menurut Qasim Amin., Laporan Penelitian.Fakultas Ushuludin, 1988., h.19

55 Abdurrahman Wahid., Islamku, Islam anda, Islam Kita: Agama Masyarakat Demokrasi, Jakarta, Wahid Institutu, 2006, h.15.

${ }^{6}$ Mustagfhiri Asror, Emansipasi Wanita dalam Syariat Islam, Jakarta, Toha Putra, 1983., h.23.

7 Viktor Situmorang, Kedudukan Wanita di Mata Hukum, Jakarta, Bina Aksara, 1999, h.9

${ }^{8}$ Denny JA, Membaca Isu Politik, Yogyakarta, LKiS, 2006, h.99. 
kata al- rijal untuk laki-laki dan al-nisa untuk perempuan, peran mana berlaku tidak mutlak.

Sebagai contoh dalam Undang-Undang Nomor 7 tahun 1989 yang telah diubah menjadi Undang-Undang Nomor 3 tahun 2006 dan diamandemen menjadi Undang-Undang Nomor 50 tahun 2009 Pasal 13 dinyatakan bahwa syarat menjadi Hakim pada Pengadilan Agama tidak menyebutkan harus pria tetapi cukup sebagai warga Negara Indonesia yang dapat ditafsirkan mencakup laki-laki maupun wanita. Syarat yang sama juga berlaku untuk posisi Panitera, Juru Sita atau pegawai di Pengadilan Agama, bahkan syarat menduduki jabatan structural tidak lagi dibedakan dan disyaratkan berdasarkan gender seseorang, tetapi berdasarkan kapabilitas dan kapasitas kemampuan seseorang.

Berdasarkan pemaparan di atas, maka sangat yang akan dibahas dalam penulisan ini terkait dengan posisi perempuan dalam sistem hukum di Indonesia, apakah hukum di Indonesia telah memberikan kedudukan yang sama antara laki-laki untuk berkiprah di dalam kekuasaan kehakiman di Indonesia dan bagaimana pandangan para ulama tentang perempuan menjadi hakim serta apa syarat-syarat menjadi hakim di Indonesia memberikan kesempatan yang sama antara laki-laki dan perempuan?

\section{Pembahasan}

Hakim diangkat dan diberhentikan oleh Presiden selaku kepala Negara atas usul Menteri Agama berdasarkan persetujuan Ketua Mahkamah Agung sesuai ketentuan Pasal 15 Undang-Undang Republik Indonesia Nomor 7 Tahun 1989 Tentang Peradilan Agama sedangkan untuk pemberhentian hakim pada Pengadilan Agama dan Pengadilan Tinggi Agama dapat diberhentikan dengan hormat dari jabatannya karena:

a. Ternyata tidak cakap.

b. Sakit jasmani maupun rohani yang terus-menerus sehingga tidak memungkinkan dia untuk melaksanakan kewajibannya dengan baik.

c. Permintaan sendiri.

d. Telah berumur 60 (enampuluh) tahun.

Selanjutnya hakim dapat diberhentikan sementara dari jabatannya:

a. Apabila seorang hakim pada Pengadilan Agama atau Pengadilan Tinggi Agama ditahan atas diperintahkan untuk dimasukkan dalam rumah sakit Jiwa.

b. Apabila hakim tersebut huruf a tersangkut dalam suatu perkara meski pun tidak dikenakan tahanan, atau setelah diadakan penyelidikan secara 
administratif timbul hal-hal yang tidak membenarkan dia melanjutkan tugasnya sebagai Hakim. Pemberhentian itu dilakukan oleh Menteri agama dengan pertimbangan Ketua Mahkamah Agung.

c. Apabila yang tersebut huruf $b$ itu mengenai hakim-hakim pada Mahkamah Agung bidang Agama, maka pemberhentian sementara dilakukan oleh Presiden atas pertimbangan Ketua Mahkamah Agung dan Menteri agama.

Untuk Pemberhentian sementara hanya dapat dicabut oleh Menteri agama. Bagi para hakim Pengadilan Agama dan Pengadilan Tinggi Agama, dan oleh Presiden bagi hakim-hakim Mahkamah Agung Bidang Agama, setelah mendapat pertimbangan dari Ketua Mahkamah Agung dan Menteri agama..

Selanjutnya Hakim-hakim pada Pengadilan Agama dan Pengadilan Tinggi Agama hanya dapat dipecat dari jabatannya apabila:

a. Ia dijatuhi pidana karena bersalah melakukan kejahatan.

b. Ia melakukan perbuatan yang tercela.

c. Ia terus-menerus melalaikan kewajibannya dalam menjalankan pekerjaan nya.

d. Ia melakukan rangkapan jabatan.

e. Ia memberi nasehat atau pertolongan yang bersifat memihak kepada yg berkepentingan dalam perkara yang diperiksa atau dikirakan akan di periksa.

Pemecatan tersebut diatas dilakukan atas usul dan per timbangan dari Mahkamah Agung setelah yang bersangkutan diberi kesempatan secukupnya untuk membela diri. Hakim secara etimologi merupakan kata serapan dari bahasa Arab yaitu hakim yang berarti orang yang memberi putusan atau diistilahkan juga dengan qadi, ${ }^{9}$ Hakim juga berarti orang yang melaksanakan hukum, karena hakim itu memang bertugas mencegah seseorang dari kezaliman. ${ }^{10}$ Kata hakim ini dalam pemakaiannya dipersamakan dengan qadi yang berarti orang yang memutus perkara dan menetapkannya. ${ }^{11}$ Lembaga peradilannya disebut dengan qada. Menurut Undang-Undang Peradilan Agama

${ }_{9}^{9}$ A.W. Munawwir, Kamus Al-Munawwir Arab- Indonesia, (Surabaya; Pustaka Progressif, 1997), h.286.

${ }^{10}$ Ibn Manzur, Lisan Arab, (Beirut: Dar Sadir li Taba'ah wa al- Nasyar, 1956), Juz. 12, h.140-141. Dalam sejarah Islam, sebutan bagi orang yang mengadili suatu perkara biasa dikenal dengan nama qadi. Antara qadi dan hakim, pada dasarnya mempunyai makna yang sama yaitu orang yang mengadili suatu perkara.

${ }^{11}$ Muhammad Salam Madkur, Al- Qada fi al- Islam, (Mesir: Dar al- Nahdah al- Arabiyah, t. t.), h.11. 
hakim adalah pejabat yang melaksanakan tugas kekuasaan kehakiman. ${ }^{12}$ Ia merupakan salah satu unsur terpenting dalam lembaga peradilan termasuk peradilan agama dan memainkan peranan yang sangat besar dalam melaksanakan pemberlakuan hukum Islam dan merupakan orang yang paling bertanggung jawab sepenuhnya dalam menjaga dan mempertahankan hukum Islam.

Demikian beratnya tugas hakim, tentu tidak semua orang mampu menduduki jabatan tersebut. Hal inilah yang menyebabkan pentingnya pemberian kriteria khusus dan penyaringan tersendiri bagi orang yang akan diangkat menjadi hakim. Ini bertujuan untuk memastikan bahwa orang yang memegang jabatan hakim benar-benar credible dan berkelayakan. Secara umum, bila berbicara mengenai kesiapan untuk menjadi hakim, terlebih lagi yang menyangkut mental, maka secara hipotesis yang sering didiskriminasikan adalah pihak perempuan. Kemampuan perempuan dalam hal ini selalu dipertanyakan.

Sikap seperti ini terjadi karena semasa Rasulullah SAW. hidup, tidak pernah ditemukan contoh kasus bahwa beliau pernah memberikan kepercayaan kepada perempuan untuk mengemban tugas sebagai hakim. Sedangkan untuk pria telah banyak, seperti Abu Musa al-Asy`ari, Umar ibn al-Khattab, Ali ibn Abi Talib, Mu'az ibn Jabal, dan sebagainya. Pendirian seperti ini berlanjut terus sampai masa- masa sesudahnya, bahkan berdasarkan ini juga jumhur ulama, khususnya kalangan mazhab Syafi $i$, tidak membolehkan perempuan menjadi hakim.

Pada tahun 1975 Departemen Agama merekrut para sarjana Syariah untuk diangkat sebagai hakim pada Pengadilan Agama.Sehubungan dengan hal ini banyak juga para sarjana wanita mengajukan permohonan untuk diangkat menjadi hakim pada Pengadilan Agama. Terhadap hal ini timbul pro dan kontra, sehing- +ga Menteri Agama R.I. menyarankan untuk dibicarakan di dalam sidang Alim Ulama Terbatas pada tanggal 14-17 Juli 1975 di Jakarta. Dalam musyawarah tersebut disimpulkan antara lain; (1) hakim wanita dalam pengadilan adalah masalah perselisihan di kalangan mujtahidin; (2) ada wanita yang menjadi hakim pada Pengadilan Agama yang sudah berjalan beberapa waktu yang lalu adalah sesuai kemaslahatan; (3) oleh karena itu pengangkatan wanita pada jabatan hakim Pengadilan Agama dapat dibenarkan.

\section{Peluang Perempuan Menjadi Hakim dan Hakim Ketua}

Dalam sistem peradilan, hakim memegang peran yang sangat penting, ia tidak hanya sebagai penegak hukum dan keadilan saja, tetapi hakim juga sebagai

12 Undang-Undang Peradilan Agama, Ed. Yudha Pandu, (Indonesia Legal Center Publishing, 2006), h.4. 
pejabat negara yang memilki tugas yaitu untuk mewujudkan negara hukum dan selalu berupaya memberikan suatu kepasian hukum4 dan juga kemanfaatan di tengah-tengah kehidupan sosial masyarakat melalui putusan hukumnya dipengadilan.

Berangkat dari tugas seorang hakim, berarti seorang hakim perempuan pun mengemban tugas yang sama dengan hakim laki-laki, tetapi bagaimana kesempatan seorang hakim perempuan untuk menjadi hakim ketua dan hakim anggota dalam menyelesaikan sebuah perkara, mengingat ada yang beranggapan bahwa seorang perempuan itu lemah.

Berdasarkan hasil penelitian di pengadilan Agama Jakarta yang telah dilakukan oleh penulis, bahwasannya kesempatan hakim perempuan untuk menjadi hakim ketua dan hakim anggota itu, sama saja dengan hakim laki- laki, bahkan tidak dibeda-bedakan, dan tidak ada yang namanya hakim laki- laki dan hakim perempuan, lebih tepatnya disebut "Hakim".

\section{Posisi Perempuan di Pengadilan Agama}

Saat ini jumlah kaum hawa yang berkiprah di peradilan agama cukup signifikan. Dari total 11.555 orang, baik tenaga teknis maupun non-teknis, aparat peradilan agama yang berjenis kelamin perempuan berjumlah 3.940 orang atau mencapai 34 persen. Data itu diperoleh Badilag.net dari Subdit Data dan Evaluasi pada Direktorat Pembinaan Tenaga Teknis Peradilan Agama, awal Desember 2013 lalu.

Dari 3.940 orang perempuan yang berkarir di peradilan agama, yang menjadi hakim berjumlah 778 orang. Namun perlu dicatat, semakin ke atas, jumlah dan prosentase hakim perempuan di lingkungan peradilan agama semakin sedikit.

Di tingkat pertama, dari total 3.080 orang, hakim perempuan berjumlah 737 orang atau 24 persen. Di tingkat banding, dari total 553 orang, hakim perempuan berjumlah 41 orang atau 7 persen. Sedangkan di tingkat kasasi, dari total 6 orang hakim agung di Kamar Agama MA, tidak ada satupun hakim agung perempuan atau prosentasenya nol. Di peradilan agama, selain jadi hakim, kaum hawa lebih juga berkiprah sebagai tenaga kepaniteraan, kejurusitaan dan kesekretariatan. Di tingkat pertama, dari total 2927 tenaga kepaniteraan, 1188 orang atau 41 persen di antaranya merupakan kaum hawa. Di tingkat banding, dari total 329 tenaga kepaniteraan, pegawai perempuan berjumlah 1221 orang atau 37 persen.

Di bagian kejurusitaan, yang dituntut memiliki mobilitas tinggi, juga ada kaum hawa. Saat ini dari total 291 jurusita, yang berjenis kelamin perempuan 
berjumlah 21 atau hanya 7 persen. Sementara perempuan yang berstatus jurusita pengganti berjumlah 384 orang atau 32 persen dari total 1200 jurusita pengganti.

Kaum perempuan paling banyak berkarir sebagai tenaga non-teknis atau kesekretariatan. Di tingkat pertama, dari total 2509 tenaga non-teknis, yang berjenis kelamin perempuan berjumlah 1121 orang atau 45 persen. Sedangka di tingkat banding, dari total 666 tenaga non-teknis, jumlah pegawai perempuan mencapai 327 orang atau 49 persen.

Sejauh ini Badilag.net belum mendapatkan data yang rinci mengenai jumlah perempuan yang berhasil jadi Ketua, Wakil Ketua, dan Panitera/Sekretaris, baik di pengadilan tingkat pertama maupun banding. Meski demikian, secara umum, data di atas sudah dapat menggambarkan kiprah kaum hawa di peradilan agama saat ini.

\section{Pandangan Ulama Tentang Kedudukan Hakim Perempuan}

1. Pendapat Imam Syafi'i

Menurut jumhur ulama dikalangan mazhab syafi'i, maliki dan hambali, laki-laki merupakan syarat untuk dapat di angkat sebagai kadi.13 Anak kecil dan wanita tidak sah menjadi hakim.14 Tidak sah wanita diangkat sebagai kadi, apabila ada pihak yang mengangkat wanita sebagai kadi, maka putusan yang dijatuhkan itu tidak sah.

Hal ini didasarkan kepada firman Allah dalam surat an-Nisa' ayat 34 yang mengatakan bahwa:

"Kaum lelaki itu adalah pemimpin bagi kaum perempuan, oleh karena Allah telah melebihkan sebagian mereka (lelaki) atas sebagian yang lain (perempuan) dan karena mereka (laki-laki) telah menafkahkan sebagian dari harta mereka".

Imam Syafi'i menjadikan ayat diatas sebagai dalil tidak bolehnya perempuan menduduki jabatan hakim, akan tetapi dia tidak mengemukakan cara istidlal dengan terperinci bagaimana caranya mengeluarkan hukum dari ayat tersebut. Namun untuk melihat pendapat ini, kita dapat melacak tulisan imam Syafi'i dalam kitabnya Al-Um. Disini dia mengatakan bahwa perempuan mempunyai kekurangan jika dibandingkan dengan pria. Oleh karena itu pria dijadikan sebagai pemimpin (Qawwam), hakim, berjihad, memperoleh harta dua bahagian dibanding perempuan, dan sebagainya.

Oleh karena Imam Syafi'i tidak memgemukakan cara istidlal maka disini akan dikemukakan cara istidlal yang ditempuh oleh ulama yang sependapat 
dengannya, antara lain Imam Al-Qurtubi. Dia menjadikan Q.S. An-Nisa' ayat 34 sebagai dalil bahwa perempuan tidak boleh menjadi hakim. Hal ini dipahami dengan kata "qawwam" atau pemimpin. Kata ini mempunyai tiga arti yaitu :1. hukkam (hakim), 2. Umara (penguasa), 3. Man yazku (orang yang berperang). Demikian penafsiran kata qawwam oleh Imam Al-Qurtubi.

Dalil kedua yang dijadikan alasan oleh Imam Syafi'i tentang tidak bolehnya perempuan menduduki jabatan hakim adalah hadits Rasul SAW yang diriwayatkan oleh Imam Ahmad, Bukhari, Nas'i dan Turmudji dari Abi Barkah yang berbunyi: "Tidak diberi keuntungan suatu umat jika mereka menyerahkan urusan mereka untuk dipimpin oleh perempuan".

Pendapat ini juga didasarkan pada sebuah hadis dari Abi Barkah dimana Rasulullah SAW pernah bersabda bahwa suatu bangsa tidak akan jaya apabila pemerintahan dipegang oleh kaum wanita. Rasulullah SAW menyampaikan hal ini ketika mendengar Raja Persia telah mati dan rakyat Persia melantikkan anak perempuannya menjadi Ratu.

\section{Pendapat Imam Hanafi}

Imam Abu Hanifah menjelaskan bahwa wanita boleh diangkat sebagai kadi untuk memutuskan perkara yang menerima persaksian wanita, dan tidak boleh memangku jabatan kadi dalam masalah yang menerima persaksiannya. Jika ada penguasa yang mengangkat wanita sebagai hakim, maka pengangkatannya itu sah tetapi orang yang mengangkatnya memangku dosa. Demikian juga dengan putusan yang dijatuhkan oleh kadi wanita itu tetap dianggap sah, kecuali kasus-kasus hudud dan qisas. Hujah golongan yang menyetujui pendapat mazhab Abu Hanifah ini didasarkan kepada qiyas, bahwa wanita boleh menjadi saksi dalam berbagai masalah, maka wanita juga bisa menjabat sebagai kadi dalam berbagai perkara, terutama perkara-perkara yang diharuskan wanita bisa menjadi saksi.

Imam Hanafi menghubungkan pendapatnya itu dengan hukum kesaksian. Menurut beliau setiap orang yang dapat diterima kesaksiannya dalam kasus tertentu, maka orang tersebut bisa menjadi hakim dalam kasus tertentu pula. Demikian pula sebaliknya, seseorang yang tidak bisa menjadi saksi dalam kasus tertentu, maka untuk menjadi hakim pun tidak dibolehkan. Disini terlihat jelas suatu hubungan hukum yang erat antara kebolehan menjadi hakim dengan kebolehan menjadi saksi.

Adanya upaya Imam Hanafi untuk mempersamakan ketentuan hukum yang berlaku bagi hakim dengan ketentuan hukum yang berlaku bagi saksi dipandang mempunyai aspek persamaan yang dominan. Kedua hal ini samasama berperan dalam mewujudkan nilai suatu keputusan hukum, namun masih 
sulit sekali untuk menentukan mana yang lebih dominan diantara keduanya. Sebagai contoh, penentuan syarat yang ketat bagi saksi dimaksudkan agar keterangan yang diberikan benar-benar sesuai dengan fakta, akan tetapi hal itu akan menjadi sia-sia bila hakim yang memutuskan perkara tersebut adalah zhalim. Hal ini sama sia-sianya jika hakim yang adil memutuskan hukum berdasarkan keterangan yang diberikan oleh saksi yang menyembunyikan kebenaran (saksi palsu). Dengan demikian kedua hal tersebut sama-sama penting guna mewujudkan suatu keputusan hukum yang adil.

Untuk lebih jelasnya hubungan diatas, maka perlu dijelaskan ketentuan hukum kesaksian menurut Imam Hanafi. Hal ini dapat dilihat dari dua aspek yaitu:

a. Kesaksian dua orang perempuan bersama seorang pria;

Ketentuan ini didasarkan pada firman Allah SWT Q.S. al-Baqarah ayat 282 yang artinya:

“Dan persaksikanlah dengan dua orang saksi dari orang -orang lelaki (di antara kamu), jika tak ada dua orang lelaki maka (boleh) seorang lelaki dan dua orang perempuan dari saksi-saksi yang kamu ridhai, jika seorang lupa maka seorang lagi mengingatkannya..."

\section{b. Kesaksian perempuan secara mandiri}

Imam Hanafi dengan tegas mengatakan kesaksian perempuan secara mandiri tidak dapat diterima. Hal ini didasarkan pada ketentuan Q.S. al-Baqarah ayat 282. Didalam ayat tersebut ditegaskan bahwa saksi haruslah terdiri dari dua orang laki-laki, atau kalau tidak terpenuhi maka boleh kesaksian seorang pria ditambah dengan dua orang perempuan. Selanjutnya dalam ayat tersebut dikemukakan pula agar para saksi dapat mengingatkan satu sama lainnya jika salah satunya lupa. Dengan demikian dapat dipahami bahwa Imam Hanafi pada prinsipnya tidak membolehkan perempuan untuk menjadi saksi secara mandiri. Namun ia juga memberikan pengecualian terhadap kasus-kasus yang dipandang "khususiah" bagi kaum perempuan. Untuk kasus ini ia menerima kesaksian perempuan secara mandiri, karena kalau tidak akan menyulitkan dalam pembuktian. Hal ini disebabkan karena pria tidak dapat menyaksikan kasus tersebut.

Indonesia menganut prinsip yang memperbolehkan wanita boleh diangkat menjadi kadi (hakim wanita) yang diperkerjakan pada pengadilan Agama dan Mahkamah Syariah Nanggroe Aceh Darussalam. Bahkan ada di beberapa tempat, wanita juga menjadi ketua dan wakil ketua Pengadilan Agama dan Mahkamah Syariah. Kebolehan mengangkat wanita dalam jabatan kadi yang diperkirakan di Pengadilan Agama dan Mahkamah Syariah NAD itu hasil 
musyawarah ulama senior yang dipimpin oleh Hasbi Ash Shiddieqy pada tahun tujuh puluhan. Mungkin para ulama terbatas waktu itu mendasarkan kepada mazhab Abu Hanifah dalam mengambil keputusan tentang dibolehkannya mengangkat wanita sebagai kadi.

\section{Pendapat Ibn Jarir at-Tabari}

Abu Said al-Hasan bin Abi Hasan Yasar al-Basri, Ibn Jarir at-Tabari, dan Mazhab az-Zahiri berpendapat bahwa wanita boleh menjadi hakim secara mutlak, yakni dalam semua perkara.

Ibn Jarir at-Tabari berpendapat bahwa perempuan boleh menjadi hakim secara umum sama seperti kesempatan yang diperoleh kaum pria. Logika yang ditempuh Ibn Jarir at-Tabari dengan memberi ketentuan bahwa setiap orang yang boleh memberi fatwa (menjadi mufti), maka orang tersebut boleh pula memutuskan perkara (diangkat menjadi hakim). Disini jelas ada kaitan yang erat antara seorang hakim dengan seorang mufti.

Sebelum menganalisis lebih jauh pendapat Ibn Jarir at-Tabari tentang hakim perempuan, perlu dijelaskan mengenai fatwa itu sendiri. Hal ini dapat ditemukan dari ucapannya tentang kebolehan perempuan berfatwa. Ibn Jarir atTabari dengan tegas Persamaan hak dan kedudukan merupakan semangat yang terkandung dalam berbagai instrumen hak asasi manusia internasional dan nasional. Persamaan hak dan kedudukan tersebut juga mencakup persamaan hak di hadapan hukum antara laki-laki dan perempuan. Berikut ini adalah jabaran dari instrumen hak asasi manusia internasional dan nasional mengenai hak wanita atas persamaan di hadapan hukum.

\section{Hak Wanita atas Persamaan di Hadapan Hukum dalam Instrumen HAM Internasional}

\section{Universal Declaration of Human Rights}

Terdapat dalam Pasal 7 yang menyebutkan bahwa:

"Semua orang sama di depan hukum dan berhak atas perlindungan hukum yang sama tanpa diskriminasi. Semua berhak atas perlindungan yang sama terhadap setiap bentuk diskriminasi yang bertentangan dengan Pernyataan ini dan terhadap segala hasutan yang mengarah pada diskriminasi semacam itu"

Ketentuan tersebut menggunakan istilah "semua orang atau all human beings" tanpa pembedaan jenis kelamin, yang menggambarkan bahwa hak asasi manusia melekat pada setiap orang, baik pria maupun wanita. 


\section{Kovenan Internasional tentang Hak-hak Sipil dan Politik}

Terdapat dalam Pasal 14 ayat (1) yang menyebutkan bahwa "Semua orang mempunyai kedudukan yang sama di hadapan pengadilan dan badan peradilan..." Terdapat juga dalam Pasal 26 yang menyebutkan bahwa:

"Semua orang berkedudukan sama di hadapan hukum dan berhak atas perlindungan hukum yang sama tanpa diskriminasi apapun. Dalam hal ini hukum harus melarang diskriminasi apapun, dan menjamin perlindungan yang sama dan efektif bagi semua orang terhadap diskriminasi atas dasar apapun seperti ras, warna, jenis kelamin, bahasa, agama, politik, asal-usul kebangsaan atau sosial, kekayaan, kelahiran atau status lain."

Dua pasal dalam ICCPR diatas, menunjukkan bahwa tidak ada pembedaan apapun, termasuk jenis kelamin terhadap hak wanita untuk memperoleh kesamaan di depan hukum dan melakukan perbuatan hukum.

\section{Konvensi tentang Penghapusan Segala Bentuk Diskriminasi Terhadap Perempuan}

Pasal 15 yang menyebutkan bahwa:

1. States Parties shall accord to women equality with men before the law; 2 . States Parties shall accord to women, in civil matters, a legal capacity identical to that of men and the same opportunities to exercise that capacity. In particular, they shall give women equal rights to conclude contracts and to administer property and shall treat them equally in all stages of procedure in courts and tribunals; 3.States Parties agree that all contracts and all other private instruments of any kind with a legal effect which is directed at restricting the legal capacity of women shall be deemed null and void; 4.States Parties shall accord to men and women the same rights with regard to the law relating to the movement of persons and the freedom to choose their residence and domicile.

Pasal 15 ini menegaskan bahwa wanita memiliki hak yang sama dengan pria di depan hukum. Begitu pula dalam hukum perdata, wanita dan pria memiliki hak yang sama, termasuk hak membuat perjanjian, mengelola kekayaan, dan beracara di pengadilan.

\section{Instrumen HAM Nasional Mengenai Hak Wanita Atas Kesamaan di Hadapan Hukum}

\section{Undang-Undang Dasar 1945}

Perlindungan hak wanita atas kesamaan di depan hukum, diakui dalam konstitusi tertulis Indonesia, yaitu Undang-undang Dasar 1945 Pasal 28D menyatakan bahwa "Setiap orang berhak atas pengakuan, jaminan, perlindungan, 
dan kepastian hukum yang adil serta perlakuan yang sama di hadapan hukum." dalam pasal ini, istilah "setiap orang" yang berarti bahwa perlakuan yang sama di hadapan hukum berlaku bagi setiap orang, pria dan wanita, tanpa pembedaan jenis kelamin.

Selain itu, dalam pasal 27 ayat (1) juga dinyatakan bahwa "Segala warga negara bersamaan kedudukannya di dalam hukum dan pemerintahan dan wajib menjunjung hukum dan pemerintahan itu dengan tidak ada kecualinya". Dalam pasal 27 ayat (1) juga menggunakan istilah "segala warga negara", yang berarti kedudukan di dalam hukum dan pemerintahan tidak mengenal pembedaan jenis kelamin dan gender.

\section{Undang-Undang no 39 tahun 1999 tentang Hak Asasi Manusia}

Dalam Pasal 17 dinyatakan bahwa "Setiap orang. tanpa diskiriminasi, berhak untuk memperoleh keadilan dengan mengajukan permohonan. pengaduan, dan gugatan... Undang-undang ini merupakan pengejawantahan semangat Deklarasi Universal Hak Asasi Manusia, yang menyatakan bahwa hak atas keadilan merupakan hak asasi yang melekat kepada setiap manusia. Pasal ini juga menggunakan istilah "setiap orang" yang menunjukkan bahwa tidak ada diskriminasi apapun, termasuk gender untuk memperoleh keadilan melalui hukum.

Selain itu, dalam pasal 29 ayat (2) dinyatakan bahwa "Setiap orang berhak atas pengakuan di depan hukum sebagai manusia pribadi di mana saja ia berada." Yang dimaksud setiap orang disini berarti setiap insan manusia yang tidak dibatasi oleh sekat-sekat apapun, termasuk gender. Hal ini dipertegas dalam UU HAM ini, yang menyebutkan bahwa "Hak wanita dalam Undang-undang ini adalah hak asasi manusia." Pasal ini memperjelas kedudukan wanita yang dijamin haknya secara penuh dalam undang-undang ini, termasuk haknya untuk memperoleh kesamaan di depan hukum.

Pengaturan lebih khusus mengenai hak wanita atas kesamaan di depan hukum, diatur dalam Pasal 50, yang selengkapnya berbunyi "Wanita yang telah dewasa dan atau telah menikah berhak untuk melakukan perbuatan hukum sendiri, kecuali ditentukan lain oleh hukum agamanya." Hal ini menghapus keraguan terhadap kecakapan wanita melakukan perbuatan hukum atas kehendaknya sendiri. Pembatasan menurut hukum agama yang tercantum dalam pasal tersebut, merupakan perwujudan dari pemahaman partikularistik relatif yang merupakan pemahaman jaminan perlindungan Hak Asasi Manusia di Indonesia menurut Muladi. HAM sebagai masalah universal juga nasional dari masingmasing bangsa. 


\section{Surat Edaran Mahkamah Agung No. 3 tahun 1963 perihal Gagasan mengganggap Burgerlijk Wetboek tidak sebagai Undang-undang (Penghapusan Pasal 108 dan 110 BW)}

Surat Edaran Mahkamah Agung No. 3 tahun 1963 merupakan terobosan atas perlindungan hak wanita atas kesamaan di hadapan hukum. Surat Edaran tersebut menghapus pasal-pasal yang dianggap tidak relevan lagi dengan kehidupan bernegara. Salah satu pasal yang dihapus adalah pasal 108 dan pasal 110 KUHPer (Burgerlijk Wetboek) tentang wewenang seorang isteri untuk melakukan perbuatan-hukum dan untuk menghadap di muka pengadilan. Pasal 108 dan 110 KUHPer menyebutkan bahwa wanita bersuami tidak cakap melakukan perbuatan hukum dan menghadap di muka pengadilan tanpa izin atau bantuan dari suami. Selengkapnya pasal 1 Surat Edaran tersebut berbunyi:

\footnotetext{
“Sebagai konsekuensi dari gagasan ini, maka Mahkamah Agung menganggap tidak berlaku lagi antara lain pasal-pasal berikut dari Burgerlijk Wetboek: 1. Pasal-pasal 108 dan 110 KUHPerd. (dalam naskah aslinya ditulis B.W.) tentang wewenang seorang isteri untuk melakukan perbuatan-hukum dan untuk menghadap di muka pengadilan tanpa izin atau bantuan dari suami. Dengan demikian tentang hal ini tidak ada lagi perbedaan di antara semua warga negara Indonesia."
}

Dengan surat edaran ini, hak wanita untuk melakukan perbuatan hukum terjamin oleh peraturan perundangan yang berlaku.

Beranjak dari logika terdahulu yang dikemukakan oleh Ibn Jarir at-Tabari, yaitu menganalogikan tugas kehakiman terhadap adanya persyaratan yang dibutuhkan bagi seorang mufti, maka sampailah ia pada kesimpulan bahwa perempuan itu boleh menjadi hakim. Kenyataan seperti ini berawal dari menganalogikan tugas kehakiman kepada kesempatan menjadi mufti, kemudian dinyatakan bahwa perempuan boleh menjadi mufti, yang akhirnya sampai pada kesimpulan bahwa perempuan boleh menjadi hakim.

Selanjutnya mengenai dalil yang diajukan oleh kedua ulama terdahulu baik Imam Syafi'i maupun Imam Hanafi seperti: Q.S an-Nisa' ayat 34, Q.S alBaqarah ayat 282 dan hadis Rasul SAW yang diriwayatkan oleh Imam Ahmad, Bukhari, Nasa'i dan Turmudzi dan Abi Barkah, semuanya ditolak oleh Ibn Jarir at-Tabari. Karena menurut dia tidak ada yang secara tegas mengatur tugas kehakiman

\section{Kesimpulan}

Berdasarkan hasil pemaparan di atas maka dapat disimpulkan:

1. Kedudukan wanita dalam ranah penegakan hukum di Indonesia khususnya di Pengadilan agama sudah sama dengan laki, ketentuan 
Pasal 13 ayat (1) bab II Undang-Undang Nomor 50 tahun 2009. Jadi jelas dari segi normatif Undang-Undang tidak membedakan syarat hakim hanya laki-laki. Ini sesuai dengan teori keadilan yang mendasarkan sesuatu sesuai dengan hak dan kewajiban masing-masing dan dengan Undang-Undang nomor 50 tahun 2009 ini terdapat asas kepastian hukum bahwa perempuan memiliki kesamaan didepan hukum khususnya menjadi seorang hakim maupun peqawai di pengadilan agama.

2. Peran wanita di Pengadilan Agama daerah Khusus Ibukota Jakarta sesuai dengan Undang-Undang Nomor 50 tahun 2009 sudah sama dengan peran laki-laki dalam hal profesi seorang hakim, panitera maupun juru sita bahkan ketika menjadi pejabat di struktural.

\section{Saran}

Kedudukan perempuan meskipun sudah sama dengan laki-laki di Pengadilan Agama namun harus tetap harus meningkatkan kualitas keilmuan dan kualitas kerja sehingga dapat menempati posisi yang sesuai dengan kebutuhan. Mahkamah Agung tidak perlu mengeluarkan rekomendasi keterwakilan perempuan di Pengadilan Agama, yang dibutuhkan adalah kesamaanimplentasi hak-hak perempuan sama dengan laki-laki.

\section{Daftar Pustaka}

Aji, Ahmad Mukri. Urgensi Maslahat Mursalah Dalam Dialektika Pemikiran Hukum Islam, Bogor: Pustaka Pena Ilahi, 2012.

Apeldoorn, L.J. Van. Pengantar Ilmu Hukum, Jakarta: Pradnya Paramita, cetakan kedua puluh enam, 1996.

Asror, Mustagfhiri. Emansipasi Wanita dalam Syariat Islam, Jakarta: Toha Putra, 1983.

Faiz, Pan Mohamad. Teori Keadilan John Rawls. dalam Jurnal Konstitusi, Volue 6 Nomor 1 (April 2009),

Friedrich, Carl Joachim. Filsafat Hukum Perspektif Historis, Bandung: Nuansa dan Nusamedia, 2004.

Hartono, C.F.G. Sunaryati. Penelitian Hukum di Indonesia Pada Akhir Abab Ke-20, Bandung, Alumni, 1994.

Huijbers, Theo. Filsafat Hukum dalam lintasan sejarah, cet VIII, Yogyakarta: kanisius, 2005.

Ibn Manzur, Lisan Arab, Beirut: Dar Sadir li Taba'ah wa al- Nasyar, 1956, Juz. 12.

JA, Denny. Membaca Isu Politik, Yogyakarta, LKiS, 2006. 
Kelsen, Hans. General Theory of Law and State. diterjemahkan oleh Rasisul Muttaqien, Bandung: Nusa Media, 2011.

Lubis, Dahlia. Konsep Emansipasi Wanita Menurut Qasim Amin., Laporan Penelitian. Fakultas Ushuludin, 1988.

Lunis, Suhrawardi K. Etika Profesi Hukum, Cetakan Kedua, Jakarta: Sinar Grafika, 2000.

Madkur, Muhammad Salam. Al-Qada fi al-Islam, Mesir: Dar al- Nahdah alArabiyah, t.t.

Masyhur, Kahar. Membina Moral dan Akhlak, Jakarta: Kalam Mulia, 2005.

Munawwir, A.W. Kamus Al-Munawwir Arab-Indonesia, Surabaya; Pustaka Progressif, 1997,

Purbacaraka, Purnadi; Soekanto, Soerjono. Renungan Tentang Filsafat Hukum, Jakarta: Rajawali, 2002.

Rahman, Budi Munawar. Sekularis, Liberalis, dan Plularisme, Islam Progresif dan Perkembangan Diskursusnya, Jakarta, PT. Gramedia, 2010.

Rawls, John. A Theory of Justice, diterjemahkan oleh Uzair Fauzan dan Heru Prasetyo, Teori Keadilan, Yogyakarta: Pustaka Pelajar, 2006.

Rohim, Nur. "Kontroversi Pembentukan Perppu No. 1 Tahun 2013 Tentang Mahkamah Konstitusi Dalam Ranah Kegentingan Yang Memaksa" Jurnal Cita Hukum [Online], Volume 2 Number 1 (1 June 2014).

Shant, Dellyana. Konsep Penegakan Hukum, Yogyakarta: Liberty, 2008.

Situmorang, Viktor. Kedudukan Wanita di Mata Hukum, Jakarta, Bina Aksara, 1999.

Soekanto, Soerjono. Faktor-Faktor Yang Mempengaruhi Penegeakan Hukum Cetakan Kelima. Jakarta: Raja Grafindo Persada, 2004.

Soekanto, Soerjono; Mamuji, Sri. Penelitian Hukum Normatif; Suatu Tinjauan Singkat. Jakarta, Rajawali Pers, 1985.

Undang-Undang Peradilan Agama, Ed. Yudha Pandu, Indonesia Legal Center Publishing, 2006.

Undang-undang Republik Indonesia Nomor 12 Tahun 2011 tentang Pembentukan Peraturan Perundangan-undangan

Wahid, Abdurrahman. Islamku, Islam anda, Islam Kita: Agama Masyarakat Demokrasi, Jakarta, Wahid Institutu, 2006.

Yunus, Nur Rohim. Restorasi Budaya Hukum Masyarakat Indonesia, Bogor: Jurisprudence Press, 2012. 
Perempuan Dalam Penegakan Hukum di Indonesia; Studi Peran Perempuan di Pengadilan Agama DKI Jakarta 


\title{
Transformasi Pendidikan Pancasila dan Wawasan Kebangsaan Bagi Generasi Milenial Untuk Revitalisasi Anti Korupsi"
}

(Transformation of Pancasila Education and Nationalism for Millennials to do Anti-Corruption Revitalization)

\author{
Supriyadi Ahmad ${ }^{1}$ \\ Universitas Islam Negeri Syarif Hidayatullah Jakarta, Indonesia
}

\section{do) $10.15408 /$ sjsbs.v4i1.7868}

\begin{abstract}
.
Pancasila learning in schools and universities has seemed difficult to understand by the millennial generation, as well as National Knowledge Education. Therefore, it is necessary to transform or change the form, nature and function of Pancasila Education, so that this State Philosophy becomes attractive, attracts interest, and can be easily implemented in everyday life. Anti-Corruption Education is also time to be revitalized, rejuvenated, and re-actualized, so that it can be more easily absorbed by the millennial generation in particular, and the citizens of Indonesia in general from an early age. The chronic economic conditions of the Indonesian people, one of which is caused by the rise of corruption in certain groups of this nation. Therefore, it is time for various efforts to improve learning for both aspects that are very urgent in the life of this nation and state.

Keywords: Transformation, Pancasila, Nationalism Insights, Millennial Generation, and Anti Corruption
\end{abstract}

\begin{abstract}
Abstrak.
Pembelajaran Pancasila di sekolah dan Perguruan Tinggi selama ini terkesan sulit dipahami oleh generasi milenial. Begitu juga Pendidikan Wawasan Kebangsaan. Oleh karena itu, perlu dilakukan transformasi atau perubahan bentuk, sifat, dan fungsi Pendidikan Pancasila agar Falsafah Negara RI ini menjadi atraktif, mengundang minat, dan dapat diimplementasikan dengan mudah dalam kehidupan sehari-hari. Pendidikan Anti Korupsi juga sudah saatnya direvitalisasi, direjuvenasi, dan direaktualisasi agar dapat dengan lebih diserap oleh generasi milenial khususnya, dan warga bangsa Indonesia pada umumnya sejak dini. Kronisnya kondisi perekonomian rakyat Indonesia, salah satunya disebabkan oleh maraknya korupsi di kalangan tertentu bangsa ini. Oleh karena itu, sudah saatnya dilakukan berbagai upaya untuk membenahi pembelajaran untuk kedua aspek yang sangat urgen dalam kehidupan berbangsa dan bernegara ini.

Kata Kunci: Transformasi, Pancasila, Wawasan Kebangsaan, Generasi Milenial, dan Anti Korupsi.
\end{abstract}

* Diterima tanggal naskah diterima: 12 Desember 2016, direvisi: 22 Maret 2017, disetujui untuk terbit: 20 April 2017.

1 Penulis adalah Dosen Tetap Fakultas Syariah dan Hukum, Universitas Islam Negeri (UIN) Syarif Hidayatullah Jakarta. Jl. Ir. H. Juanda No. 95 Ciputat Tangsel. E-mail: supriyadi.ahmad@uinjkt.ac.id. 


\section{Pendahuluan}

Sangat mendesak, Pancasila diajarkan di Sekolah dan Perguruan Tinggi di Indonesia dengan metode baru. Wacana transformasi Pendidikan Pancasila mengemuka akhir-akhir ini, terutama setelah pada bulan Juni 2017 Pemerintah RI menerbitkan Undang-Undang Nomor 2 Tahun 2017 tentang Perubahan atas UU Organisasi Kemasyarakatan. Di antara konten UU tersebut adalah pembubaran ormas-ormas yang dianggap bertentangan dengan Pancasila. Hal ini juga menimbulkan pro dan kontra di kalangan masyarakat, karena dianggap dapat mengancam eksistensi ormas-ormas yang berkembang di Indonesia. Namun, ada juga yang menyetujui UU ini karena Pancasila merupakan ideologi dasar Negara ini.

Karena model pembelajaran Pendidikan Pancasila selama ini sulit dipahami oleh generasi milenial, maka perlu dilakukan transformasi atas pola pembelajaran Falsafah Negara yang pernah redup pamornya di akhir pemerintahan Orde Baru di tahun 1998. "Metode penyampaian Pancasila pun tidak atraktif, tidak mengundang minat anak-anak muda generasi milenial untuk melihat Pancasila sebagai sesuatu yang terkoneksi dengan kehidupan nyata mereka sehari-hari". Demikian ujar Yudi Latif, Kepala Unit Kerja Presiden Pembinaan Ideologi Pancasila (UKP-PIP). ${ }^{2}$ Artinya perlu transformasi atau perubahan bentuk pembelajaran, sifat, dan fungsi Pancasila bagi generasi muda atau generasi milenial yang akan mengaktualisasikan nilai-nilai Pancasila dalam kehidupan sehari-hari.

Krisis politik di Indonesia yang ditandai antara lain dengan terungkapnya kasus mega korupsi e-KTP (KTP Elektronik) yang melibatkan nama-nama besar di negeri ini telah menyebabkan krisis kepercayaan rakyat kepada para pemimpin negeri dan pejabat negara berlambang burung garuda yang gagah ini. Kerugian negara akibat kasus korupsi e-KTP ini diprediksi sebanyak Rp. 2,3 triliun "Padahal-demikian pendapat umum dan seorang penulis muda--korupsi adalah perbuatan yang hina". ${ }^{3}$ Dalam Islam, bahkan korupsi disetarakan dengan pencurian, penggelapan uang negara, atau penipuan terhadap makhluk Allah yang pelakunya harus dijerat dengan hukuman yang berat, karena termasuk tindak pidana berat.

Dalam kaitan dengan pembangunan karakter bangsa, Pendidikan Wawasan Kebangsaan dapat digunakan sebagai modal awal dalam pembangunan bangsa dan karakter atau moral bangsa. Dengan kondisi seperti itu, maka eksistensi Indonesia sebagai bangsa (nation) sedang dipertaruhkan. Oleh karena itu, dewasa ini adalah saat yang sangat tepat untuk melakukan re-

\footnotetext{
2 Astri Novaria, "Perkenalkan Pancasila dengan Gaya Keseharian" dalam Rubrik Politik dan Hukum Koran Media Indonesia, Jumat, 21 Juli 2017, h.6.

3 Yarabisa Yanuiar, "Korupsi Perbuatan yang Hina", dalam Rubrik Islam Digest, Pembaca Menulis, Harian Republika, Ahad, 23 Juli 2017, h.14.
} 
evaluasi terhadap proses terbentuknya "nation and character building" bangsa Indonesia, karena boleh jadi persoalan-persoalan yang dihadapi bangsa saat ini berawal dari kesalahan dalam menghayati dan menerapkan konsep awal "kebangsaan" yang menjadi fondasi ke-Indonesia-an.

\section{Transformasi Pendidikan Pancasila}

Dalam makalah ini yang dimaksud dengan "transformasi Pendidikan Pancasila" adalah perubahan bentuk, sifat, dan fungsi ${ }^{4}$ pendidikan Pancasila dari yang selama ini bersifat konvensional menjadi sesuatu yang lebih atraktif, menarik minat, dan memberi muatan-muatan pesan moral yang lebih akademis kepada Pancasila. Lebih dari itu, melalui lembaga baru UKP-PIP yang dibentuk Presiden RI, Joko Widodo, berdasarkan Peraturan Presiden Nomor 54 Tahun 2017, Pancasila bukan saja diajarkan di Sekolah dan Perguruan Tinggi, tetapi Pancasila harus diperkuat dengan pengamalannya dalam kehidupan seharihari. ${ }^{5}$ Bahkan hal itu harus juga terintegrasi dengan program pembangunan, termasuk pemberantasan kemiskinan dan pemerataan kesejahteraan.

Lebih lanjut dapat dijelaskan bahwa Pancasila-di samping sebagai dasar negara-juga berfungsi sebagai ideologi dan pandangan hidup bangsa Indonesia. ${ }^{6}$ Bukan hanya itu. Pancasila juga diakui sebagai dasar idiil Negara. Sedangkan UUD 1945 adalah dasar struktural Negara. Inilah yang harus diperhatikan oleh seluruh komponen bangsa Indonesia, termasuk para guru dan dosen yang di antara tugasnya adalah melakukan pembelajaran terhadap peserta didiknya, termasuk pembelajaran Pancasila.

Sudah saatnya Pancasila harus diajarkan dengan diberi muatan nilai-nilai transenden dan direjuvenasi. Dalam Kamus Besar Bahasa Indonesia dalam Jaringan (Daring), rejuvenasi diartikan dengan dengan peremajaan. ${ }^{7}$ Dalam arti yang lebih luas, rejuvenasi adalah mengukuhkan kembali-dalam hal ini Pancasila--dan mengembangkannya dalam wacana ilmiah. ${ }^{8}$ Demikian menurut Yudi Latif, sebagaimana dikutip oleh $\mathrm{A}$. Ubaedillah ketika membahas tentang reaktualisasi Pancasila.

\footnotetext{
${ }^{4}$ Penjelasan lebih detail tentang hal ini dapat dilihat di website resmi Kembendikbud dengan alamat: http://kbbi.web.id/transformasi. Diunuh pada hari Selasa, 25-07-2017.

${ }^{5}$ Nur Aivanni, “ Ego Sektoral Hambat Kerja UKP PP" dalam Kolom Politik Harian Media Indonesia, Kamis, 20-07-2017, h.4.

${ }^{6}$ Ahmad Sukardja, dan Ahmad Sudirman Abbas, Demokrasi dalam Perspektif Islam: Studi Perbandingan antara Konsep Syura dan Demokrasi Barat dalam Kaitannya dengan Demokrasi Pancasila, Jakarta: Pedoman Ilmu dan Anglo Media Jakarta, 2005, h.108.

7http://kbbi.kemdikbud.go.id/entri/rejuvenasi . (Diunduh hari Rabu, 26 Juli 2017).

${ }^{8}$ A. Ubaedillah, Pancasila, Demokrasi, dan Pencegahan Korupsi, Jakarta: Prenadamedia Group, 2015, h.32-33.
} 
Masih berkaitan dengan rejuvenasi, tampaknya kata ini juga sepadan dan sejalan dengan kata revitalisasi yang berarti proses, perbuatan menghidupkan atau menggiatkan kembali. ${ }^{9}$ Kedua kata ini-rejuvenasi dan revitaslisasi-juga senada dengan kata lain yang lebih umum yaitu reaktualisasi yang berarti proses, perbuatan mengaktualisasikan kembali atau penyegaran dan pembaruan nilai-nilai kehidupan masyarakat. ${ }^{10}$ Dalam kaitan wacana dalam makalah ini, reaktualisasi lebih difokuskan pada penyegaran kembali nilai-nilai Pancasila dalam kehidupan masyarakat secara nyata.

\section{Transformasi Pendidikan Wawasan Kebangsaan}

Secara etimologis, dalam Kamus Besar Bahasa Indonesia "wawasan" berarti tinjauan, pandangan, konsepsi, atau cara pandang. Sedangkan "Kebangsaan" berarti ciri-ciri yang menandai golongan bangsa, atau perihal bangsa, atau mengenai (yang bertalian dengan) bangsa, atau kesadaran diri sebagai warga negara. ${ }^{11}$

Wawasan kebangsaan juga dapat diberi makna sebagai cara seseorang atau sekelompok orang melihat keberadaan dirinya yang dikaitkan dengan nilainilai dan spirit kebangsaan dalam suatu negara. Nilai-nilai dan spirit dalam kehidupan berbangsa dan bernegara yang disepakati dan dirumuskan oleh pendiri bangsa sebagai pedoman merupakan filsafah hidup bangsa. Semakin mengerti dan mendalami nilai-nilai dan spirit yang telah disepakati bersama dalam suatu negara, serta menerapkannya dalam kehidupan berbangsa dan bernegara, maka bangsa dan negara itu semakin kokoh pula eksistensinya.

Selain itu, wawasan kebangsaan dapat dijelaskan sebagai berikut. Wawasan berarti kemampuan memahami atau cara memandang suatu konsep tertentu yang direfleksikan dalam perilaku tertentu sesuai dengan konsep atau pokok pikiran yang terkandung di dalamnya. Sedangkan kebangsaan adalah tindak-tanduk, kesadaran, atau sikap yang memandang pengertian bahwa dirinya itu adalah bagian dari suatu kelompok bangsa yang sama dengan keterikatan sosio-kultural yang disepakati bersama. ${ }^{12}$ Oleh karena itu, jika dikaitkan dengan negara Republik Indonesia, maka wawasan kebangsaan dapat juga sebagai suatu cara pandang mendasar dan komprehensif bagi bangsa Indonesia, sebagai cara pandang yang berdasarkan falsafah hidup bangsa Indonesia yaitu Pancasila dan Undang-Undang Dasar Republik Indonesia 1945 mengenai diri dan lingkungannya, mengutamakan persatuan dan kesatuan

${ }^{9}$ http://kbbi.kemdikbud.go.id/entri/revitalisasi. (Diunduh hari Rabu, 26 Juli 2017).

${ }^{10} \mathrm{http}$ ///kbbi.kemdikbud.go.id/entri/reaktualisasi (Diunduh hari Rabu, 26 Juli 2017).

${ }^{11}$ Diunduh dari website www.KamusBahasaIndonesia.org (Rabu, 26 Juli 2017).

12 Teguh Suyitno, "Revisi Wawasan Kebangsaan", Presentasi Disajikan pada Diklat Prajabatan Nasional Angkatan Sabtu, 24 April 2010, Kementerian Agama, Balai Pendidikan dan Pelatihan Keagamaan Semarang 2010. 
bangsa, serta mengutamakan persatuan dan kesatuan bangsa serta kesatuan wilayah, meningkatkan kesejahteraan dan melindungi segenap warga bangsa, dan berperan aktif dalam pergaulan dunia. ${ }^{13}$ Pengertian yang disebutkan terakhir ini dapat dikatakan lebih luas dan lebih komprehensif, karena melibatkan pandangan dan pergaulan global, di samping secara nasional.

Selain itu, wawasan kebangsaan dapat dijelaskan sebagai berikut. Wawasan berarti kemampuan memahami atau cara memandang suatu konsep tertentu yang direfleksikan dalam perilaku tertentu sesuai dengan konsep atau pokok pikiran yang terkandung di dalamnya. Sedangkan kebangsaan adalah tindak-tanduk, kesadaran, atau sikap yang memandang pengertian bahwa dirinya itu adalah bagian dari suatu kelompok bangsa yang sama dengan keterikatan sosio-kultural yang disepakati bersama. ${ }^{14}$

Oleh karena itu, jika dikaitkan dengan negara Republik Indonesia, maka wawasan kebangsaan dapat juga sebagai suatu cara pandang mendasar dan komprehensif bagi bangsa Indonesia, sebagai cara pandang yang berdasarkan falsafah hidup bangsa Indonesia yaitu Pancasila dan Undang-Undang Dasar Republik Indonesia 1945 mengenai diri dan lingkungannya, mengutamakan persatuan dan kesatuan bangsa, serta mengutamakan persatuan dan kesatuan bangsa serta kessatuan wilayah, meningkatkan kesejahteraan dan melindungi segenap warga bangsa, dan berperan aktif dalam pergaulan dunia. ${ }^{15}$ Pengertian yang disebutkan terakhir ini dapat dikatakan lebih luas dan lebih komprehensif, karena melibatkan pandangan dan pergaulan global, di samping secara nasional.

Secara historis, bangsa Indonesia telah melalui perjuangan yang begitu panjang untuk dapat mewujudkan keberadaan Negara Kesatuan Republik Indonesia (NKRI). Hakikat Wawasan Kebangsaan Indonesia adalah juga suatu pandangan yang mencerminkan sikap dan kepribadian bangsa Indonesia yang memiliki rasa cinta tanah air, menjunjung tinggi kesatuan dan persatuan, memiliki rasa kebersamaan sebagai bangsa untuk membangun Indonesia menuju masa depan yang lebih baik, di tengah persaingan dunia yang globalistik, tanpa harus kehilangan akar budaya yang telah dimiliki oleh bangsa ini.

Nilai-nilai kejuangan bangsa Indonesia berkenaan dengan upaya tidak kenal lelah untuk tetap eksis secara bermartabat. Sejarah perjuangan bangsa Indonesia telah menunjukkan betapa nilai-nilai kejuangan itu telah membangkitkan semangat pantang menyerah untuk membebaskan diri dari berbagai bentuk penindasan. Itu sebabnya, nilai-nilai kejuangan para generasi sebelumnya perlu diwariskan hingga proses perkembangan dan

\footnotetext{
${ }^{13}$ Kementerian Dalam Negeri Republik Indonesia, Modul Wawasan Kebangsaan, h.v.

${ }^{14}$ Diunduh dari http://www.scribd.com/doc/43885395/Kemerosotan-Integrasi-BangsaDitinjau-Dari-Wawasan-Kebangsaan-Dalam-Kerangka-Nkri (Rabu, 26 Juli 2017).

15 Kementerian Dalam Negeri Republik Indonesia, Modul Wawasan Kebangsaan, h.v.
} 
pembangunan bangsa ini tidak memudar. Integrasi nasional adalah salah satu faktor penting yang terdapat pada pembahasan mengenai wawasan kebangsaan. Integrasi nasional sendiri adalah suatu proses penyatuan atau pembauran berbagai aspek sosial budaya ke dalam kesatuan wilayah dan pembentukan identitas nasional atau bangsa. Integrasi nasional sebagai konsep dalam kaitannya dengan wawasan kebangsaan dalam NKRI pada dasarnya berlandaskan pada aliran pemikiran atau paham integralistik.

Dari beberapa hal yang dikemukakan di atas, maka dapat dipahami bahwa bangsa Indonesia harus terus melakukan rejuvinasi wawasan kebangsaan dalam rangka meningkatkan persatuan dan kesatuan bangsa. Wawasan kebangsaan juga sangat diperlukan dalam rangka pembinaan karakter dan jati diri bangsa. ${ }^{16}$ Hal ini sangat bermanfaat untuk meningkatkan kualitas kebangsaan, sehingga bangsa ini mampu mengatasi berbagai permasalahan kebangsaan termasuk masalah disintegrasi bangsa.

Pada saat ini diperlukan adanya upaya-upaya untuk melakukan rejuvenasi terhadap wawasan kebangsaan. Beberapa upaya yang dapat dilakukan dalam memantapkan Wawasan Kebangsaan, antara lain: ${ }^{17}$

1. Meningkatkan kesadaran segenap komponen bangsa untuk menerima, menghormati, dan menghargai segala bentuk keragaman.

2. Membangun sikap, moral, dan etika segenap komponen bangsa sesuai dengan Pancasila dan UUD 1945.

3. Meningkatkan sosialisasi Wawasan Kebangsaan guna membangun kehidupan Nasional yang harmonis.

4. Mengoptimalkan pembelajaran Wawasan Kebangsaan yang sejalan dengan proses reformasi dan tidak indoktrinasi.

5. Membangun nilai-nilai luhur budaya atas dasar Wawasan Kebangsaan untuk membangun semangat otonomi daerah.

6. Meningkatkan rasa hormat kepada simbol-simbol negara.

7. Meningkatkan keteladanan dari para pimpinan nasional.

Dengan cara itu, sesungguhnya wawasan kebangsaan secara jelas dapat memberikan jaminan atas tercapainya kepentingan nasional baik ke dalam maupun keluar. Hal ini berarti bahwa Wawasan Kebangsaan memberikan gambaran dan arah yang jelas bagi kelangsungan hidup bangsa, sekaligus perkembangan kehidupan bangsa dan negara di masa depan.

${ }^{16}$ Kementerian Dalam Negeri Republik Indonesia, Modul Wawasan Kebangsaan, h.v-vi.

${ }^{17}$ Kementerian Dalam Negeri Republik Indonesia, Modul Wawasan Kebangsaan, h.5-6. Lihat pula A. Ubaedillah dkk, Modul Implementasi dan Sosialisasi Wawasan Kebangsaan (Draf), (Jakarta: Direktorat Jenderal Kesatuan Bangsa dan Politik Kemendagri, 2012), h.12-13. 
Era reformasi dan demokrasi, memang harus tetap berjalan. Namun, penataan kehidupan berbangsa dan bernegara, harus berjalan di atas rel kesepakatan bersama, yakni Pancasila, UUD 1945, NKRI, dan slogan Bhinneka Tunggal Ika. Hal ini menjadi sangat penting ketika dikaitkan dengan pencapaian Visi Indonesia 2025. ${ }^{18}$ Oleh karena itu, perlu kajian kritis dan akademik tentang Urgensi Rejuvinasi wawasan kebangsaan dan relevansinya dengan pencapaian visi Indonesia 2025 tersebut.

Beberapa core materi yang diperlukan dalam pendidikan wawasan kebangsaan untuk mewujudkan visi Indonesia 2025, dapat disebutkan sebagai berikut. ${ }^{19}$

1. Persatuan dan Harmoni Nasional (Unity and National Harmony);

2. Stabilitas Nasional (National Stability) dan ketahanan nasional (National Resilience);

3. Demokrasi dan Masyarakat Madani (Democracy and Society);

4. Hukum dan Ketertiban (Law and Order);

5. Pertumbuhan Ekonomi (Economy Growth);

6. Kesejahteraan Rakyat (people welfare);

7. Tata pemerintahan yang baik (good governance);

8. Pembangunan Daerah yang intensif (Intensive Regional Development);

9. Kerjasama Global (Global Partnership);

Core-core materi yang harus diketahui masyarakat seperti disebutkan di atas menjadi sangat urgen karena beberapa alasan yang dapat dijelaskan lebih lanjut. Wawasan kebangsaan tentang nasionalisme dan pembangunan karakter merupakan materi yang berorientasi ke masa depan sebagai bangsa yang tangguh, mempunyai daya saing yang tinggi, dan berakhlak mulia. Selain itu, dengan persatuan dan harmoni nasional yang makin kokoh, maka bangsa Indonesia akan kuat persatuannya, tinggi keadilannya dengan tatanan kehidupan sosial kemasyarakatan yang harmonis dan wawasan kebangsaan yang utuh.

18 Visi Indonesia 2025 adalah slogan yang dirancang untuk mewujudkan mimpi dan rencana pembangunan jangka panjang bangsa Indonesia agar bangsa ini tetap dapat sejajar dengan bangsa-bangsa lain di dunia, yaitu Indonesia yang mandiri, maju, adil, dan makmur. Presiden ke6 RI, Soesilo Bambang Yudoyono juga menyampaikan slogan yang agak sedikit berbeda tentang impian atau visi Indonesia, ketika berbicara pada Sidang Kabinet Terbatas di Istana Bogor, 30 Desember 2010, dan Raker Pemerintah di JCC 10 Januari 2011 dengan menyatakan bahwa impian lain Indonesia ke depan adalah juga Indonesia yang Sejahtera, Demokratis, dan Berkeadilan.

${ }^{19}$ Kementerian Dalam Negeri Republik Indonesia, Modul Wawasan Kebangsaan, hal. 16-18. Lihat pula A. Ubaedillah dkk, Modul Implementasi dan Sosialisasi Wawasan Kebangsaan (Draf), (Jakarta: Direktorat Jenderal Kesatuan Bangsa dan Politik Kemendagri, 2012), h.17-19. 
Materi yang tidak kalah pentingnya adalah stabilitas nasional dan ketahanan nasional. Ini menjadi penting karena akan mendukung pembangunan bangsa di segala lini. Demokrasi dan masyarakat madani juga akan mendukung pembangunan bangsa. Pemahaman masyarakat terhadap hukum dan ketertiban juga sangat urgen. Begitu pula pertumbuhan ekonomi dan kesejahteraan rakyat. Tidak juga kalah pentingnya masyarakat juga harus memahami tata kelola pemerintahan yang baik dan bersih (Good and Clean Governance). Otonomi daerah dan kerjasama global juga perlu mendapat perhatian dari masyarakat agar pembangunan karakter bangsa tidak terhenti hingga nasional, tetapi juga melewati batas-batas dan sekat-sekat negara yang tanpa batas.

\section{Generasi Milenial dan Pendidikan Anti Korupsi}

Generasi milenial dapat diartikan sebagai generasi millennium yang berarti generasi masa kini, yang juga dapat dimaknai dengan generasi hidup di abad ke-21. ${ }^{20}$ Generasi milenial di Indonesia pada umumnya dapat mengakses informasi dari media social yang berkaitan dengan informasi-informasi aktual, termasuk korupsi. Korupsi, menurut Kamus Besar Bahasa Indonesia, korupsi berarti penyelewengan atau penggelapan uang negara atau perusahaan dan sebagainya untuk keuntungan pribadi atau orang lain. ${ }^{21}$ Korupsi terambil dari bahasa Latin corruptio atau corruptus yang berarti merusak, tidak jujur, dapat disuap, atau sesuatu yang rusak atau hancur.

Kata ini juga diambil dari bahasa modern sehari-hari Eropa seperti bahasa Inggris untuk menyebut kerusakan fisik seperti frasa a corrupt manuscript-yang berarti naskah yang rusak - dan dapat juga digunakan untuk menyebut kerusakan tingkah laku atau tidak bermoral (immoral) atau tidak jujur atau tidak dapat dipercaya (dishonest). Korupsi juga berarti tidak bersih (impure).

Syed Hussein Alatas menegaskan bahwa "esensi korupsi adalah pencurian melalui penipuan dalam situasi yang mengkhianati kepercayaan". ${ }^{22}$ Korupsi juga didefinisikan sebagai "ajakan (dari seseorang pejabata publik) dengan pertimbangan-pertimbangan yang tidak semestinya untuk melakukan pelanggaran tugas." 23

Selain definisi-definisi diatas, masih cukup banyak. Azyumardi Azra memberikan definisi yang cukup simple untuk hal ini. Korupsi menurutnya -

${ }^{20}$ Milenial diambil dari kata millennium yang berarti masa atau jangka waktu seribu tahun. Lihat Pranala (link): http://kbbi.web.id/milenium

${ }^{21}$ Pusat Pembinaan dan Pengembangan Bahasa, Kamus Besar Bahasa Indonesia, Edisi Kedua, (Jakarta: Depdikbud dan Balai Pustaka, 1999), h.527.

${ }^{22}$ Syed Hussein Alatas, Korupsi: Sifat, Sebab, dan Fungsi, Alih Bahasa Nitwono, (Jakarta: LP3ES, 1987), h.viii.

${ }^{23}$ Syamsul Anwar, "Sejarah Korupsi dan Perlawanan Terhadapnya di Zaman Awal Islam: Perspektif Studi Hadis”, dalam Hermenia Volume 4, Nomor 1, Januari - Juni 2005, h.108. 
dengan mengutip pendapat Leiken--adalah "penggunaan kekuasaan public (public poer) untuk mendapatkan keuntungan (material) pribadi atau kemanfaatan politik." 24 Definisi ini menyebutkan unsur keuntungan material, karena korupsi juga terkait dengan keuntungan nonmaterial yang mungkin jauh lebih banyak. Dalam hal ini, tampaknya Azyumardi Azra ingin menyebutkan definisi minimalis, tetapi mencakup hampir seluruh bentuk kasus korupsi.

Secara yuridis, korupsi disebutkan sebagai suatu "perbuatan memperkaya diri sendiri atau orang lain atau suatu korporasi yang dapat merugikan keuangan negara atau perekonomian negara." 25 Itulah yang disebutkan dalam Undang-undang Republik Indonesia Nomor 31 Tahun 1999 tentang Pemberantasan Tindak Pidana Korupsi, pasal 2 ayat 1. Dalam pasal 3 undang-undang itu juga disebutkan bahwa korupsi adalah setiap tindakan dengan tujuan menguntungkan diri sendiri atau orang lain atau suatu korporasi, menyalahgunakan kewenangan, kesempatan, atau sarana yang ada padanya karena jabatan atau kedudukan yang dapat merugikan keuangan negara atau perekonomian negara.

Dalam data Indeks Persepsi Korupsi 2016 yang dilansir Transparency International, Indonesia berada di peringkat 90 dari 176 negara dengan skor $37 .{ }^{26}$ Ini tentu membuat prihatin bagi rakyat Indonesia. Bangsa ini masih terlilit korupsi yang sangat menjatuhkan harga diri bangsa ini. Bangsa Indonesia yang dikenal sangat agamis dan anti sekulerisme, tentan sangat tidak berpihak kepada perilaku korupsi ini.

Para pakar mempunyai pemikiran yang bervariasi tentang modus korupsi. M. Amien Rais, mantan ketua MPR dan mantan ketua PP Muhammadiyah berpendapat bahwa sedikitnya ada empat modus korupsi, yaitu yang ia sebut dengan korupsi ekstortif, korupsi manipulatif, korupsi nepotistik, dan korupsi subversif. ${ }^{27}$ Lebih lanjut, Amen Rais menjelaskan bahwa yang ia maksud dengan korupsi ekstortif adalah korupsi dengan modus sogokan atau suap yang dilakukan oleh pengusaha kepada penguasa, untuk mendapatkan fasilitas tertentu. Korupsi manipulatif mengandung arti permintaan seseorang kepada pejabat legislatif atau pejabat eksekutif tertentu untuk membuat regulasi atau peraturan tertentu yang dapat menguntungkan orang tersebut meskipun hal itu berdampak negatif bagi kepentingan rakyat banyak. Korupsi nepotistik

${ }^{24}$ Azyumardi Azra, "Pemberantasan Korupsi Menuju Tata Pemerintahan yang Baik," Makalah Tidak Diterbitkan. Disampaikan pada Seminar Internasional Memberantas Korupsi, Hotel Le Meridien, Jakarta, 16-17 Desember 2003.

${ }^{25}$ Presiden dan DPR RI, Kumpulah, Perundang-undangan Anti KKN, (Yogyakarta : Pustaka Widyatama, 2005), h.41.

26 (https://ekbis.sindonews.com/read/1174166/35/ini-negara-paling-korup-di-duniaindonesia-peringkat-90-1485344785) Diunduh hari Selasa, 25-07-2017

${ }_{27}$ M. Amien Rais, Membangun Politik Adiluhung, (Bandung: Zaman Wacana Mulia, 1998), Cet. Ke-1, h.180-187. 
adalah korupsi yang terjadi karena ada ikatan kekeluargaan. Korupsi jenis ini, misalnya terjadi jika seseorang pejabat atau pengusaha memberikan fasilitas tertentu yang berlebihan atau tidak masuk akal kepada keluarganya tanpa mempertimbangkan kredibilitasnya. Hal ini tentu berdampak negatif terhadap kepentingan orang banyak atau pihak lain. Sedangkan korupsi subversif adalah korupsi dengan modus perampokan kekayaan negara secara sewenang-wenang untuk dialihkan kepada pihak asing, dengan sejumlah keuntungan pribadi. Amien menyebutkan beberapa contoh modus korupsi modus ini seperti korupsi yang terjadi pada kasus Freeport, Busang, Barrick dan Bre-X dan lain-lain. Korupi modus ini dilakukan dengan memberi kewenangan kepada pihak perusahaan asing untuk mengelola sumber daya alam Indonesia kepada pengusaha luar negeri, tetapi dengan memberikan keuntungan tertentu kepada pihak-pihak yang mempunyai kewenangan untuk mengatur kebijakan.

Lebih dari itu, Alatas menyebutkan enam modus korupsi. ${ }^{28}$ Modusmodus korupsi tersebut ialah: 1. Transaktif, 2. Investif, 3. Ekstroktif, 4. Nepotistik, 5. Autogenetik, dan, 6. Supportif. Dalam penjelasannya, Alatas mengatakan bahwa korupsi transaktif ialah korupsi yang ditandai adanya kesepakatan timbal-balik antara pihak yang memberi dan yang menerima demi keuntungan bersama, dan kedua belah pihak sama-sama aktif menjalankan perbuatan ini. Jika seorang pengusaha menyuap penguasa untuk memenangkan tender sebuah pembangunan proyek tertentu, itulah bagian dari korupsi dengan modus transaktif. Alatas selanjutnya menjelaskan tentang korupsi investif adalah sebuah modus korupsi yang melibatkan penawaran barang atau jasa tertentu agar pekerjaan atau tugas si pemberi jasa mendapatkan keuntungan sebanyak mungkin. Seseorang yang memberikan cindera mata atau akomodasi atau konsumsi yang berlebihan kepada seorang pejabat yang melakukan kunjungan ke daerah karena ingin mendapatkan sesuatu dalam tugas-tugas pokoknya, adalah bagian dari modus korupsi investif. Korupsi ekstroktif adalah bentuk korupsi dengan cara menyertakan bentuk-bentuk pemaksaan dari pihak tertentu untuk melakukan penyuapan dengan cara memberikan sejumlah uang atau jasa untuk menutupi kerugian yang mengancam dirinya. Seorang pengusaha yang mendapatkan tekanan untuk menyetorkan sejumlah uang kepada pihak lain untuk memperlancar kinerjanya, adalah bagian dari modus korupsi ekstroktif. Korupsi nepotistik. Korupsi autogenetik ialah modus korupsi dengan menggnakan kesempatan untuk memperoleh keuntungan dari pengetahuan dan pemahaman atas sesuatu yang hanya diketahui oleh dirinya sendiri. Seseorang yang melakukan penggelembungan harga barang atau pelipatgandaan upah tenaga kerja atau mark-up biaya perjalanan berarti ia telah melakukan korupsi modus autogenetik. Begitu juga orang yang melakukan double accaunt yaitu membukukan suatu tagihan atau belanja dalam dua buah pembukuan berarti ia telah melakukan korupsi modus ini. Biaya perjalan dinas fiktif atau diskon harga

${ }^{28}$ Syed Hussein Alatas, Korupsi: Sifat, Sebab, dan Fungsi, Alih Bahasa Nitwono, op.cit, h.21. 
yang tidak dilaporkan merupakan bagian dari korupsi modus ini. Modus terakhir yang dijelaskan Alatas adalah korupsi supportif. Modus korupsi ini menurutnya adalah korupsi dengan cara menciptakan suasana kondusif untuk melindungi atau mempertahankan kelangsungan tindak pidana korupsi tertentu. Seorang pejabat yang melindungi atau membiarkan bawahannya melakukan korupsi agar tidak mengganggu perilaku korup yang dilakukan oleh atasannya itu, adalah contoh dari korupsi supportif. Perilaku pembiaran lembaga-lembaga pengawas terhadap lembaga-lembaga yang diawasinya untuk melakukan tindak pidana korupsi adalah contoh lain dari modus korupsi supportif ini.

Modus-modus lain korupsi juga dikemukakan oleh United Nations Office on Drugs and Crime, sebuah lembaga dibawah Perserikatan Bangsa-Bangsa (PBB), adalah seperti dikutip oleh Majlis Tarjih Muhammadiyah berikut. ${ }^{29}$ Ada sembilan modus korupsi menurut lembaga ini, yaitu korupsi besar dan korupsi kecil (dilihat dari jumlah uang dan tingkatan pelakunya), korupsi aktif dan korupsi tidak aktif (dilihat dari pembayaran dan penerimaan suap), korupsi suap dalam berbagai bentuk dan tujuannya, korupsi dengan modus penggelapan (termasuk pencurian dan kecurangan), korupsi bermodus pemerasan (misalnya terhadap calon pegawai atau pejabat), korupsi bermodus penyalahgunaan kekuasaan, korupsi dengan modus favoritisme (mengunggulkan seseorang atau pihak tertentu untuk kepentingan terselubung), korupsi dengan modus membuat atau mengeksploitasi kepentingan yang saling bertentangan, dan korupsi dengan modus kontribusi (dukungan atau sumbangan) politik yang berlebihan dan tidak tepat.

\section{Ajaran Normatif Islam tentang Anti Korupsi}

Secara normatif, Islam jelas-jelas melarang tindak pidana korupsi karena hal itu merugikan individu, masyarakat, maupun bangsa. Oleh karena itu, Islam sangat menekankan prinsip yang harus ditegakkan oleh masyarakat dalam memperoleh penghidupan atau penghasilan, misalnya prinsip kejujuran, prinsip amanah, dan prinsip keadilan. Prinsip kejujuran berarti tidak melakukan kecurangan dalam mencari hart benda. Prinsip amanah berarti memenuhi kewajiban, memegang tanggung jawab, dan melaksanakan kepercayaan yang menjadi tugas dalam kehidupan. Prinsip keadilan berarti berlaku seimbang dan tidak melakukan kezaliman dalam mencari rezeki sebagai bekal mendekatkan diri kepada Sang Pemberi Rezeki.

Ketiga prinsip diatas ditegaskan beberapa kali dalam al-Quran seperti dalam teks-teks suci berikut:

"Hai orang-orang yang beriman bertakwalah kepada Allah, dan hendaklah kamu bersama orang-orang yang benar. (Q.S. Al-Tawbah: 119).

${ }^{29}$ Majlis Tarjih dan Tajdid PP Muhammadiyah, op. cit., h.19-20. 
"Tidak mungkin seorang Nabi berkhianat dalam urusan harta rampasan perang. Barangsiapa yang berkhianat dalam urusan rampasan perang itu, Maka pada hari kiamat ia akan datang membawa apa yang dikhianatkannya itu, kemudian tiap-tiap diri akan diberi pembalasan tentang apa yang ia kerjakan dengan (pembalasan) setimpal, sedang mereka tidak dianiaya. (Q.S. Ali Imran : 161).

"Sesungguhnya Allah menyuruh kamu menyampaikan amanat kepada yang berhak menerimanya, dan (menyuruh kamu) apabila menetapkan hukum di antara manusia supaya kamu menetapkan dengan adil. Sesungguhnya Allah memberi pengajaran yang sebaik-baiknya kepadamu. Sesungguhnya Allah adalah Maha mendengar lagi Maha melihat. (Q.S. Al-Nisa' : 58).

"Hai orang-orang yang beriman, janganlah kamu mengkhianati Allah dan Rasul (Muhammad) dan (juga) janganlah kamu mengkhianati amanat-amanat yang dipercayakan kepadamu, sedang kamu mengetahui. (Q.S. Al-Anfal : 27).

Ayat-ayat diatas, mengeskan betapa pentingnya penegeakan prinsipprinsip kehidupan yang harus dilakukan oleh seseorang baik sebagai individu maupun sebagai anggota masyarakat. Jika norma-norma itu dilanggar, maka pihak lain akan menanggung kerugian dan kesengsaraan. Itulah sebabnya, korupsi-yang tentu saja berdampak merugikan dan menzalimi pihak laindikategorikan sebagai dosa besar dan tindak pidana.

Dengan demikian dapat disimpulkan bahwa Islam memberikan tuntunan normatif tentang anti korupsi. Bila Pacasila diajarkan secara atraktif dan selalu dilakukan reaktualisasi, ditambah dengan pendidikan wawasan kebangsaan yang rejuvenatif, maka generasi milenial khususnya dan bangsa Indonesia pada umumnya akan terhindar dari korupsi yang menyengsarakan.

\section{Kesimpulan}

Dari wacana di atas dapat disimpulkan beberapa hal sebagai berikut:

1. Pembelajaran bidan Pendidikan Pancasila harus dilakukan dengan metode yang atraktif, memacu kreatifitas, dan diberi nuansa spiritual agar dapat diimplementasikan dalam kehidupan sehari-hari.

2. Pendidikan Wawasan Kebangsaan harus mendapat perhatian yang lebih serius di masyarakat. Pendidikan pada aspek ini harus dilakukan dengan strategi-strategi yang menarik minat dan dijiwai oleh nuansa-nuansa religius yang aplikatif.

3. Korupsi telah merusak generasi milenial khususnya dan warga negara pada umumnya. Oleh karena itu, pendidikan anti korupsi harus dimulai sejak dini, dan disosialisasikan kepada seluruh warga bangsa dan negara Republik Indonesia. 


\section{Pustaka Acuan:}

Aivanni, Nur. "Ego Sektoral Hambat Kerja UKP PP" dalam Kolom Politik Harian Media Indonesia, Kamis, 20-07-2017.

Alatas, Syed Hussein. Korupsi :Sifat, Sebab, dan Fungsi, Alih Bahasa Nitwono, Jakarta : LP3ES, 1987.

Anwar, Syamsul. "Sejarah Korupsi dan Perlawanan Terhadapnya di Zaman Awal Islam: Perspektif Studi Hadis," dalam Hermenia Volume 4, Nomor 1, Januari - Juni 2005.

Azra, Azyumardi. "Pemberantasan Korupsi Menuju Tata Pemerintahan yang Baik," Makalah Tidak Diterbitkan. Disampaikan pada Seminar Internasional Memberantas Korupsi, Hotel Le Meridien, Jakarta, 16-17 Desember 2003.

Kementerian Dalam Negeri Republik Indonesia, Modul Wawasan Kebangsaan.

Majlis Tarjih dan Tajdid PP Muhammadiyah, op. cit.

Novaria, Astri. "Perkenalkan Pancasila dengan Gaya Keseharian" dalam Rubrik Politik dan Hukum Koran Media Indonesia, Jumat, 21 Juli 2017.

Presiden dan DPR RI, Kumpulan Perundang-undangan Anti KKN, (Yogyakarta: Pustaka Widyatama, 2005.

Pusat Pembinaan dan Pengembangan Bahasa, Kamus Besar Bahasa Indonesia, Edisi Kedua, Jakarta: Depdikbud dan Balai Pustaka, 1999.

Rais, M. Amien. Membangun Politik Adiluhung, (Bandung: Zaman Wacana Mulia, 1998), Cet. Ke-1.

Sukardja, Ahmad; Abbas, Ahmad Sudirman. Demokrasi dalam Perspektif Islam: Studi Perbandingan antara Konsep Syura dan Demokrasi Barat dalam Kaitannya dengan Demokrasi Pancasila, Jakarta: Pedoman Ilmu dan Anglo Media Jakarta, 2005.

Suyitno, Teguh. "Revisi Wawasan Kebangsaan", Presentasi Disajikan pada Diklat Prajabatan Nasional Angkatan Sabtu, 24 April 2010, Kementerian Agama, Balai Pendidikan dan Pelatihan Keagamaan Semarang 2010.

Ubaedillah, A. dkk, Modul Implementasi dan Sosialisasi Wawasan Kebangsaan (Draf), Jakarta: Direktorat Jenderal Kesatuan Bangsa dan Politik Kemendagri, 2012.

Ubaedillah, A. Pancasila, Demokrasi, dan Pencegahan Korupsi, Jakarta: Prenadamedia Group, 2015.

Yanuar, Yarabisa. "Korupsi Perbuatan yang Hina", dalam Rubrik Islam Digest, Pembaca Menulis, Harian Republika, Ahad, 23 Juli 2017. 


\section{Website:}

(https://ekbis.sindonews.com/read/1174166/35/ini-negara-paling-korup-di-duniaindonesia-peringkat-90-1485344785) Diunduh hari Selasa, 25-07-2017

Pranala (link):http://kbbi.web.id/milenium

http://kbbi.kemdikbud.go.id/entri/rejuvenasi . (Diunduh hari Rabu, 26 Juli 2017).

Diunduh dari website www.KamusBahasaIndonesia.org (Rabu, 26 Juli 2017).

Diunduh dari http://www.scribd.com/doc/43885395/Kemerosotan-IntegrasiBangsa-Ditinjau-Dari-Wawasan-Kebangsaan-Dalam-Kerangka-Nkri (Rabu, 26 Juli 2017). 


\title{
Korelasi Hak Asasi Manusia dan Hukum Islam* (Correlation of Human Rights and Islamic Law)
}

\author{
Daniel Alfaruqi ${ }^{1}$ \\ Universitas Islam Negeri Syarif Hidayatullah Jakarta \\ do: $\underline{10.15408 / \text { sjjbs.v4i1.7869 }}$
}

\begin{abstract}
.
The controversy between Islamic law and universal human rights continues to roll. Apart from universal claims to human rights principles, when he saw that the concept came from the West, some Muslims were suspicious and considered it an attempt to secularize Islamic law. As a result, conservative Muslims continue to reject the application of Western standards, even in the name of universal human rights, to legal problems in Muslim societies. Based on this research, it can be concluded that the Islamic response to human rights is a reflection of global, lasting and fundamental demands. By not intending to have anology, in fact Islam has first taught humanity about concepts that are egalitarian, universal and democratic. This concept that is so beautiful and comprehensive is allegedly adopted by the West through the emergence of universal ideas standardized in the convention of the Universal Declaration of Human Rights. Islamic teachings cover all aspects of human life, and of course they have included rules and high respect for human rights. But it is not in a structured document, but is spread in the holy verses of the Qur'an and the Sunnah of the Prophet Muhammad. The birth of the UDHR and the Cairo Declaration on Human Rights in Islam (CDHRI) endorsed by the OIC was an attempt to clarify the actions of Muslim countries on arrogant, authoritarian and arbitrary Western claims.
\end{abstract}

Keywords: Islamic law, human rights

\begin{abstract}
Abstrak.
Kontroversi antara hukum Islam dan hak-hak asasi manusia universal terus bergulir. Meskipun telah melekat klaim universal pada prinsip-prinsip HAM, ketika melihat bahwa konsep tersebut berasal dari Barat, sebagian umat Islam curiga dan menganggapnya sebagai usaha untuk mensekulerkan hukum Islam. Karena itu, kalangan Muslim konservatif tetap menolak penerapan standar-standar Barat, meskipun atas nama HAM universal, terhadap persoalan-persoalan hukum pada masyarakat Muslim. Berdasarkan penelitian ini diperoleh kesimpulan bahwa respon Islam terhadap hak asasi manusia adalah cerminan dari tuntutan global, abadi, dan fundamental. Dengan tidak bermaksud untuk berapologi, sesunguhnya Islam telah
\end{abstract}

* Diterima tanggal naskah diterima: 12 Desember 2016, direvisi: 22 Maret 2017, disetujui untuk terbit: 20 April 2017.

${ }_{1}$ Penulis adalah Peneliti pada Fakultas Syariah dan Hukum, Universitas Islam Negeri (UIN) Syarif Hidayatullah Jakarta. Jl. Ir. H. Juanda No. 95 Ciputat Tangsel. E-mail: daniel@uinjkt.ac.id. 
terlebih dahulu mengajarkan umat manusia tentang konsep yang egaliter, universal, dan demokratis. Konsep yang sedemikian indah dan komprehensif ini disinyalir diadopsi oleh Barat melalui pemunculan ide-ide universal yang dibakukan dalam konvensi Universal Declaration of Human Rights. Ajaran Islam meliputi seluruh aspek dari sisi kehidupan manusia, dan tentu saja telah tercakup di dalamnya aturan dan penghargaan yang tinggi terhadap hak asasi manusia (HAM). Namun memang tidak dalam satu dokumen yang terstruktur, tetapi tersebar dalam ayat-ayat suci alQuran dan Sunnah Nabi Muhammad SAW. Kelahiran UDHR dan Cairo Declaration on Human Rights in Islam (CDHRI) yang diratifikasi oleh OKI merupakan upaya penjernihan yang dilakukan oleh negara-negara Muslim atas klaim Barat yang arogan, otoriter dan semena-mena.

Kata kunci: Hukum Islam, Hak Asasi Manusia

\section{Pendahuluan}

Hak Asasi Manusia (HAM) yang telah ada pada diri manusia sejak lahir merupakan masalah yang sangat penting untuk dibicarakan. Baik yang mempertahankannya, mempertanyakan ulang, membantahnya ataupun yang ingin meratifikasi substansinya, agar bisa diaktualisasikan dalam masyarakat. Semua itu berangkat dari sebuah obsesi untuk menciptakan keharmonisan dan kedinamisan dalam kehidupan serta untuk menjaga prinsip-prinsip dasar kemanusiaan. Isu-isu hak asasi manusia selalu menjadi perdebatan menarik di kalangan pemikir modern baik di bidang politik maupun hukum. Hal ini berdasar kepada kecenderungan munculnya isu-isu hak asasi manusia bukan hanya dipengaruhi oleh anasir-anasir politik dan hukum melainkan juga agama dan budaya, termasuk tentunya dikalangan masyarakat Muslim.

Islam adalah agama yang lengkap al syumul, yang ruang lingkup ajarannya meliputi seluruh aspek kehidupan manusia. Islam memberikan pengaturan dan tuntunan pada manusia mulai dari urusan yang paling kecil hingga urusan dalam skala besar. Dan tentu saja termasuk didalamnya adalah batasan dan penghargaan yang tinggi terhadap Hak Asasi Manusia (HAM). Memang tentu saja tidak dalam bentuk yang terstruktur dalam satu bab, tetapi tersebar dalam ayat suci Al Qur'an dan Sunnah, persoalan hak asasi manusia bukanlah suatu hal baru. Syari'at Islam yang bersifat universal banyak menjelaskan prinsip-prinsip dasar tentang persamaan hak azasi manusia dan kebebasan. Bahkan ketika Nabi Muhammad SAW mendeklarasikan Piagam Madinah, hak asasi manusia ditempatkan dalam posisi tertinggi konstitusi Islam pertama tersebut.

\section{Pengertian Hak Asasi Manusia}

Hak asasi manusia (HAM) secara etimologis, merupakan terjemahan langsung dari human rights dalam bahasa Inggris, "droits de l'home" dalam bahasa Perancis, dan menselijke rechten dalam bahasa Belanda. Namun ada juga yang 
menggunakan istilah HAM sebaga terjemahan dari basic raights dan fundamental rights dalam bahasa Inggris, serta grondrechten dan fundamental rechten dalam bahasa Belanda. ${ }^{2}$

Secara terminologis, istilah hak asasi manusia sering dinamakan dengan hak-hak yang melekat pada diri manusia sejak lahir. ${ }^{3}$ Miriam Budiardjo mengatakan bahwa hak asasi adalah hak yang dimiliki manusia yang diperoleh dan dibawanya bersamaan dengan kelahiran atau kehadirannya di dalam kehidupan masyarakat. ${ }^{4}$ Sedangkan menurut Jan Meterson dari Komisi HAM PBB bahwa hak asasi manusia adalah hak-hak yang melekat pada setiap manusia, yang tanpa hak tersebut manusia mustahil dapat hidup sebagai manusia. Selanjutnya ia mengungkapkan bahwa hak tersebut adalah hak yang dibawa sejak lahir sebagai anugerah Tuhan Yang Maha Esa bukan pemberian manusia atau penguasa. Hak ini sifatnya sangat mendasar bagi hidup dan kehidupan manusia yang bersifat kodrati, yakni ia tidak dapat terlepas dari dan dalam kehidupan manusia. ${ }^{5}$

John Locke menyatakan bahwa hak asasi manusia adalah hak-hak yang diberikan langsung oleh Tuhan Yang Maha Esa sebagai hak yang kodrati. Oleh karenanya, tidak ada kekuasaan apapun di dunia yang dapat mencabutnya. ${ }^{6}$ Dalam Undang-undang Nomor 39 Tahun 1999 tentang Hak Asasi Manusia Pasal 1 disebutkan bahwa:

"Hak Asasi Manusia adalah seperangkat hak yang melekat pada hakekat dan keberadaan manusia sebagai makhluk Tuhan Yang Maha Esa dan merupakan anugrah-Nya yang wajib dihormati, dijunjung tinggi, dan dilindungi oleh Negara, hukum, pemerintah, dan setiap orang demi kehormatan serta perlidungan harkat dan martabat manusia." ${ }^{7}$

Rumusan tentang hak hak-hak asasi manusia yang dianggap legal dan dijadikan standar pada saat ini adalah yang diterbitkan oleh Badan Perserikatan Bangsa-Bangsa, yang dideklarisakan pada 10 Desember 1948 dan lebih dikenal dengan "The Universal Declaration Of Human Rights" (Deklarasi Universal tentang

${ }^{2}$ Marbangun Hardjowirogo, HAM dalam Mekanisme-mekanisme Perintis Nasional, Regional dan Internasional, (Bandung: Patma, 1977), h.10, dalam Habib Shulton Asnawi, "Hak Asasi Manusia Islam dan Barat: Studi Kritik Hukum Pidana Islam dan Hukuman Mati," Jurnal Supremasi Hukum, Vol. 1, No. 1, Juni 2012, h.28.

3 Eggi Sudjana, HAM dalam Perspektif Islam, Mencari Universalitas HAM bagi Tatanan Modersitas yang Hakiki, (Jakarta: Nuansa Madani, 2000), h.3.

${ }^{4}$ Miriam Budiardjo, Dasar-dasar Ilmu Politik, (Jakarta: Gramedia Pustaka Umum, 2000), h.120.

${ }_{5}$ Pendidikan Kewarganegaraan (Civic Education) Demokrasi, HAM dan Masyarakat Madani, (Jakarta: IAIN Press, 2000), h.207.

- Pendidikan Kewarnageraan (Civic Education) Demokrasi, HAM, dan Masayarakat Madani, (Jakarta: ICCE UIN Syarif Hidayatullah, 2003), h.200.

7 Undang-Undang No. 39 Tahun 1990 tentang Hak Asasi Manusia Pasal 1, di akses dari www.komisiyudisial.go.id, pada hari Kamis, 12 Januari 2017. 
Hak-hak Asasi Manusia), disingkat dengan UDHR. Rumusan ini terdiri dari 30 pasal. ${ }^{8}$ Pertimbangan-pertimbangan dideklerasikan hak asasi manusia ini adalah untuk menghargai harkat dan martabat alami manusia, sehingga dengan demikian ia bisa hidup bebas dan menigkatkan taraf hidupnya itu secara layak. ${ }^{9}$ Nagara-negara maju (Barat) pada umumnya mengacu kepada HAM yang dideklarasikan oleh Majlis PBB. Walaupun hampir diterima seluruh anggota PBB, tapi hak-hak asasi tersebut belum tuntas disepakati dan belum dapat mengakomodasi keinginan bangsa-bangsa di dunia yang amat beragam latar belakang budaya dan agamanya. ${ }^{10}$

Pokok-pokok yang menjadi hak bagi seluruh manusia sebagaimana dirumuskan dalam UDHR (Universal Declaration of Human Right) adalah:

1. Hak untuk memiliki martabat, tidak dihina dan tidak diperlakukan sebagai budak seperi yang tercantum pada pasal 1, pasal 4 dan pasal 5.

2. Hak untuk hidup, merdeka, dan selamat seperti pada pasal 3.

3. Hak untuk mendapatkan keadilan, perlindungan hukum, tidak ditangkap tanpa bukti yang nyata dan untuk mengeluarkan pendapat (bebas dalam bicara) dan berserikat (berkumpul membentuk organisasi) seperti pada pasal 7, 8, 9,10,11,19 dan 20 .

4. Hak untuk bebas mengurus diri dan keluarganya sendiri tanpa intervensi pihak atau instansi lain seperti pada pasal 12.

5. Hak untuk mendapatkan tempat tinggal atau hidup ditempat yang ia sukai seperti yang terdapat pada pasal 13.

6. Hak untuk lari dan mencari perlindungan ke segala penjuru dunia selama dia tidak melanggar hukum-hukum dasar PBB seperti pada pasal 14.

7. Hak untuk mendapatkan pengakuan sebagai warga negara dari negara yang dimiliki seperti pada pasal 15.

8. Hak untuk mencari dan mendapatkan jodoh secara bebas tanpa dibatasi kebangsaan, warga negara, dan agama seperti pada pasal 16.

9. Hak untuk memiliki harta (pasal 17).

10. Hak bebas untuk berpikir, mengganti agama dan beribadah (Pasal 18).

11. Berhak berdaulat dan ikut serta (berpartisipasi) dalam urusan negerinya sendiri seperti menduduki jabatan pemerintahan. (Pasal 21).

\footnotetext{
${ }^{8}$ Ahmad Kosasih, HAM Dalam perspektif Islam, (Jakarta: Salemba Diniyah, 2003), h.24.

9 Jainal Aripin, Dkk, Kumpulan Hasil Penelitian 2002, Hak Asasi Manusia dalam Tinjauan Islam Dan Implementasi di Indonesia, h.147.

${ }^{10}$ Ahmad Kosasih, HAM Dalam perspektif Islam, h. 24.
} 
12. Berhak tehadap jaminan sosial, berusaha, dan bekerja sesuai dengan keinginannya, mendapat upah dari pekerjaannya dan perlindungan kepentingan baik secara moral dan material seperti Pasal 22, 23 dan 27 ayat (2).

13. Hak untuk istirahat, liburan, menikmati seni dan berbudaya, memporoleh kesehatan dan tingkat kehidupan yang layak bagi diri dan keluarganya seperti Pasal 24, 25, dan 27 ayat (1).

14. Hak untuk mendapatkan pendidikan dan mendidik anak (Pasal 26). ${ }^{11}$

\section{Pandangan Cendekiawan Muslim Indonesia tentang HAM}

Pandangan cendekiawan Muslim yang sekaligus mewakili kalangan ulama Indonesia tentang HAM dapat dilihat dari beberapa pendapat berikut. Ali Yafie, misalnya, mendukung HAM dengan argumen konsep maslahah yang diperkenalkan para ulama fikih klasik. Dalam teori hukum (ushul figh) ada kaidah yang menyebutkan bahwa "Tujuan umum syariah Islam adalah mewujudkan kepentingan umum melalui perlindungan dan jaminan kebutuhankebutuhan dasar (al-Daruriyyah), pemenuhan kepentingan (al-Hajiyyah), dan pemenuhan perhiasan (tahsiniyah) mereka". ${ }^{12}$

Menurut Yafie, seperti dikutip oleh Masykuri, kebutuhan dasar manusia (al-Daruriyyah) meliputi jiwa (al-Nafs), akal (al-`Aql), keturunan (al-Nasab), harta benda (al-Mal) dan agama (al-Din). Islam melindungi kebutuhan dasar manusia dan melarang bentuk pelanggaran apapun terhadap kebutuhan dasar tersebut. Ditambahkannya lagi, bahwa hak-hak yang ditetapkan dalam Deklarasi Universal Hak Asasi Manusia sebenarnya termasuk di antara daruriyyah dan hajiyyah.

Pendapat yang agak kontroversial tentang hak-hak asasi ini diperlihatkan oleh Munawir Syazali. Menurutnya, benar bahwa Nabi menyerukan kepada para pemilik budak untuk memperlakukan budak mereka secara lebih manusiawi atau membebaskan mereka sekalian, namun hingga wafatnya Nabi, Islam tidak menghapus perbudakan secara total. Di zaman sekarang ini, kemanusiaan menyetujui untuk menghapus perbudakan dalam semua manifestasinya. Karenanya, jika umat Islam mempertahankan ayat-ayat yang melegitimasi perbudakan dan hal-hal yang tidak terselesaikan oleh Nabi tentang pembebasan budak, maka mereka tidak akan dapat mendiskusikan persoalan ini secara menyeluruh. Itulah sebabnya, Syazali menganjurkan untuk menafsirkan kembali

\footnotetext{
${ }^{11}$ Muhammad faisal hamdani, "Hukum keluarga islam dalam perspektif Ham universal (udhr) dan ham islam (uidhr)," Jurnal Ahkam, Vol. xvi, No. 1, Januari 2016, h.25.

${ }^{12}$ Abd. Wahab Khallaf, Ilm Ushul al-Figh (Kuwait: Dar al-Qalam, 1978), h.199.
} 
teks-teks al-Quran yang bersifat relatif (dhanni al-Dilalah) dan juga teks-teks yang bersifat absolut (qath $i$ al-Dilalah), seperti sejumlah ayat tentang perbudakan. ${ }^{13}$

Gugatan Munawir Syazali tentang teks-teks al-Quran yang dinilai kurang menghargai HAM, khususnya dalam masalah perbudakan, telah dikonfrontir secara apik oleh Azhar Basyir. Menurutnya, al-Quran tidak melarang perbudakan karena kondisi sosial saat itu dimana seluruh masyarakat mengakui perbudakan. Tiap orang menjadikan budak dari musuh-musuhnya yang tertawan, termasuk tentara-tentara muslim yang tertawan di medan perang. Sebagai penyeimbang, kata Basyir, al-Quran juga membolehkkan mereka menjadikan musuh yang tertangkap sebagai budak. Seandainya al-Quran secara eksplisit melarang perbudakan, maka tawanan-tawanan muslim akan menderita sebagai budak-budak orang kafir. ${ }^{14}$

\section{Lahirnya IUDHR dan CDHRI}

Rumusan dasar Islam tentang hak-hak asasi manusia dimunculkan oleh para ahli, sarjana, pemuka agama atau intelektual Muslim ke dalam bentuk riil piagam yang ratipikasi secara kelembagaan. Upaya ini dimulai sejak pertemuan Abu Dhabi pada tahun 1977. Dalam pertemuan tersebut dihasilkan suatu rumusan yang disebut dengan "Deklarasi Islam Universal Tentang Hak Asasi Manusia" (Islamic Universal Declaration of Human Rights, IUDHR). Deklarasi ini cukup lengkap dan benar-benar sejalan dengan dokumen hak asasi manusia PBB seperti Universal Declaration of Human Rights, konvensi tentang hak sipil dan politik, dan sebagainya.

IUDHR, terdiri dari 22 pasal: (1) hak untuk hidup, (2) hak atas kebebasan, (3) hak atas persamaan, (4) hak atas keadilan, (5) hak atas pengadilan yang adil, (6) hak atas perlindungan terhadap penyalahgunaan kekuasaan, (7) hak atas perlindungan terhadap penyiksaan, (8) hak atas perlindungan terhadap kehormatan dan nama baik, (9) hak atas suaka, (10) hak minoritas, (11) hak atas kewajiban untuk ambil bagian dalam pelaksanaan dan pengaturan urusanurusan umum, (12) hak atas kebebasan, kepercayaan, menyatakan gagasan dan berbicara, (13) hak atas kebebasan berserikat, (14) hak atas kebebasan beragama, (15) tata ekonomi dan pengembangannya, (16) hak atas perlindungan terhadap pendidikan, (17) status dan martabat pekerjaan, (18) hak atas keamanan social, (19) hak untuk berkeluarga dan hal-hal yang berkaitan, (20) hak wanita yang telah menikah, (21) hak atas kebebasan bergerak dan berkedudukan, serta (22) hak memperoleh pendidikan selengkapnya. ${ }^{15}$

\footnotetext{
${ }^{13}$ Masykuri Abdillah, Responses of Indonesian Muslim Intellectuals to the Concept of Democracy (1966-1993), terj. Wahib Wahab, (Yogyakarta: Tiara Wacana, 1999), h.101-102.

${ }^{14}$ Ismail, "Hak Asasi Manusia Menurut Perspektif Islam," Jurnal Asy-Syir'ah, Vol. 43 No. I, 2009, h.111

${ }^{15}$ Ismail, Hak Asasi Manusia Menurut Perspektif Islam, h.104-105.
} 
Ada tiga pandangan dari kelompok agama termasuk umat Islam terhadap HAM yang dideklarasikan itu, yaitu: Pertama, mereka yang menerima tanpa reserve dengan alasan bahwa HAM itu sudah sejalan dengan ajaran Islam. Kedua, mereka yang menilai bahwa konsep HAM tersebut bertolak belakang dengan ajaran Islam. Ketiga, posisi kelompok moderat yang mengambil sikap hati-hati, yakni menerima dengan beberapa perubahan dan modifikasi seperlunya. ${ }^{16}$

Islam memandang rumusan-rumusan HAM yang terdapat dalam UDHR, ada permasalahan yang prinsipil yang bertentangan dengan ajaran Islam, seperti pasal 16 mengenai perkawinan antar umat yang berbeda agama dan pasal 18 tentang hak kebebasan keluar masuk agama. Dalam pandangan Islam, perkawinan seorang muslim dengan non muslim terlarang (haram), sedangkan kebebasan keluar masuk agama adalah suatu kemurtadan. Atas dasar ini maka negara-negara yang tergabung dalam Organisasi Konferensi Islam sedunia (OKI) membuat suatu rumusan tentang HAM berdasarkan Alquran dan Sunnah yang dideklarasikan di Kairo, Mesir tanggal 5 Agustus 1990. Rumusan ini terdiri dari 25 pasal, kemudian di sebut dengan Cairo Declaration on Human Rights in Islam (CDHRI). Dekalarasi Kairo ini tidaklah membentuk rumusan HAM yang baru sama sekali tapi mengoreksi pasal-pasal yang dianggap menyimpang dari prinsip-prinsip ajaran Islam, sedangkan pada pasal yang tidak bertentangan dengan prinsip ajaran Islam diberi landasan Alquran dan Sunnah. ${ }^{17}$

\section{Islam dan Hak Asasi Manusia}

Persoalan hak asasi manusia di kalangan negara-negara muslim bukanlah suatu hal yang baru. Syariat Islam yang bersifat universal banyak menjelaskan prinsip-prinsip dasar tentang persamaan hak azasi manusia dan kebebasan. Bahkan ketika Nabi Muhammad Saw mendeklarasikan Piagam Madinah, hak azasi manusia ditempatkan dalam posisi tertinggi konstitusi Islam pertama tersebut. Perjalanan sejarah berlakunya hukum Islam di kalangan masyarakat muslim telah bergeser dari sudut normativitas vertikal menjadi lebih horizontal. Hal ini disebabkan perkembangan berlakunya hukum Islam telah dipengaruhi pula oleh dinamika sosial-budaya dan politik hukum dalam masyarakat Islam itu sendiri.

Rusjidi mengungkapkan bahwa kajian tentang HAM dalam tinjauan Islam haruslah dipahami dengan melihat fungsi manusia menurut al-Quran, yakni menempatkan hubungan manusia dengan Tuhan dalam posisi sentral. Hal ini berarti menunjukkan bahwa perilaku manusia baik dari dimensi internal (hubungan ke dalam atau dengan dirinya sendiri), maupun dimensi eksternal

${ }^{16}$ Ahmad Kosasih, HAM Dalam perspektif Islam, h.25

${ }_{17}$ Ahmad Kosasih, HAM Dalam perspektif Islam, h. 20 
(hubungan keluar atau hubungan manusia dengan segala sesuatu yang ada di luar dirinya). Kedua hubungan tersebut harus dijiwai dengan hubungan yang kebih tinggi, yakni Allah SWT. Selanjutnya Rusjidi mendiskripsikan dua hal sebagai bentuk implikasi ajaran tauhid yaitu, pertama, dengan diakuinya semua makhluk adalah ciptaan Allah, maka hubungan manusia dengan alamnya hakikatnya adalah hubungan manusia dengan sesama makhluk Allah. Kedua, implikasi ajaran tauhid ini juga menegaskan bahwasanya sesama manusia dengan manusia lainnya harus menjunjung persamaan derajat, kemuliaan harkat dan martabat. Hal tersebut mengisyaratkan bahwasanya tidak dibenarkan adanya tindakan diskriminatif atau pembedaan antara sesama manusia atau dengan alam sekitar. ${ }^{18}$

Islam memandang bahwa manusia itu mulia, karena kemuliaan yang dianugerahkan kepadanaya oleh Allah SWT. Kemuliaan itu dikaitkan dengan penyembahan manusia kepada Rabb-nya. Menurut Muhamad Ahmad Mufti dan Sami Salih al-Wakil, ${ }^{19}$ Pemikiran Barat memandang bahwa hak-hak asasi manusia merupakan hak-hak alamiyah (al-huquq athabi'iyyah atau natural right) yang mengalir dari ide bahwa kedaulatan mutlak adalah milik manusia, tidak ada pihak lain yang lebih berdaulat dari manusia. Sedangkan dalam Islam hakhak dasar manusia sebagai anugerah yang diberikan Allah SWT.

Terdapat perbedaan-perbedaan yang mendasar antara konsep HAM dalam Islam dan HAM dalam konsep Barat, antara lain:

1. HAM dalam Islam bersumber pada ajaran Alquran dan Sunnah. Dasar HAM dalam Alquran terdapat pada surat al-Hujurat ayat 13: "Hai manusia, sesungguhnya Kami menciptakan kamu dari seorang laki-laki dan seorang perempuan dan menjadikan kamu berbangsa-bangsa dan bersuku-suku supaya kamu saling kenal mengenal...."

Dikatakan bahwa manusia hidup bersuku-suku dan berbangsa-bangsa adalah untuk saling mengenal, artinya supaya manusia saling berhubungan dan saling membantu serta saling memberi manfaat, tidak mungkin terjadi hubungan yang serasi kalau tidak terpelihara hak persamaan dan kebebasan. Sedangkan HAM Barat (UDHR) bersumber pada pemikiran filosofis semata, karena sepenuhnya produk otak manusia.

2. HAM dalam Islam bersifat Theosentrik, artinya manusia dalam hal ini dilihat hanya sebagai Makhluk yang dititipi hak-hak dasar oleh Tuhan, bukan sebagai pemilik mutlak. Oleh karena itu wajib memeliharanya sesuai dengan aturan Tuhan. Dalam penegakkan, selain untuk

\footnotetext{
${ }^{18}$ Rusjidi Ali Muhammad, Hak Asasi Manusia dalam Perspektif Syari'at Islam, (Aceh: ArRaniri Press, 2004), h.93.

${ }_{19}$ Muhamad A Mufti dan Sami Salih al Wakil, HAM Menurut Barat dan HAM menurut Islam terj.Yahya Abd Rahman, (Bogor: Pustaka Thariqul Izzah, 2009), h.22.
} 
kepentingan kemanusian juga didasari atas kepatuhan dan ketaatan melaksanakan perintah Tuhan dan dalam mencari keridhoannya. Maka di dalam penegakkan HAM itu tidak boleh berbenturan dengan ajaran syariat secara komprehensif. Sedangkan HAM Barat lebih bersifat antrofosentrik, maksudnya ialah manusialah yang menjadi fokus perhatian utama. Manusia dilihat sebagai pemilik sepenuhnya hak tersebut.

3. HAM dalam Islam mengutamakan keseimbagan antara hak dan kewajiban pada seseorang. Karena itu, kepentingan sosial sangat diperhatikan. Penggunaan hak-hak pribadi di dalam Islam tidak boleh merugikan atau mengabaikan kepentingan orang lain. Apabila seseorang melakukan perbuatan sebagai haknya, tapi perbuatannya merugikan orang lain maka haknya boleh dibatasi. Sedangkan HAM barat lebih mengutamakan hak dari pada kewajiban, karena itu ia lebih terkesan individualistik.

Dalam hal ini, penggunaan hak oleh seseorang kurang memperhatikan kewajiban memelihara hak orang lain. ${ }^{20}$ Jadi, dapat disimpulkan bahwa HAM menurut Barat adalah semata-mata hasil otak manusia, yang lebih mengutamakan manusia untuk melakukan kebebasan tanpa ada batasanbatasan. Sedangkan HAM dalam Islam merupakan salah satu bagian dari pola umum syari'at. Hak-hak ini sesuci hukum-hukum syari'at lainnya dan dengan demikian hak-hak ini harus diindahkan sesuai dengan syari'at. Tidak ada ketetapan Allah yang dapat dikurangi ataupun dibatasi demi hak-hak manusia. Jadi semua hukum yang telah ditetapkan syari'at itu membatasi ruang lingkup hak-hak manusia. ${ }^{21}$

Menurut Alwi Sihab, HAM dalam perspektif Barat menempatkan manusia dalam suatu seting di mana hubungannya dengan Tuhan sama sekali tidak disebut. Hak asasi manusia dinilai sebagai perolehan alamiah sejak kelahiran. Sedangkan HAM dalam perspektif Islam, menganggap dan meyakini bahwa hak-hak manusia merupakan anugrah Tuhan oleh karenanya setiap individu akan merasa bertanggung jawab kepada Tuhan. ${ }^{22}$

Sebagai comparative perspective (wawasan pembanding) antara HAM yang bersumber dari Barat yang dilegitimasikan dalam Universal Declaration of Human Right (UDHR) atau Deklarasi Universal Hak Asasi Manusia (DUHAM) dengan HAM dalam persfektif Islam dapat dilihat sebagai berikut: ${ }^{23}$

${ }^{20}$ Ahmad Kosasih, HAM dalam Perspektif Islam, h.36-37.

${ }^{21}$ Syaukat Hussain, Hak Asasi Manusia Dalam Islam, Penerjemah: Abdul Rochim, (Jakarta: Gema Insani press, 1996), h.100.

22 Azazi, Hak Memilih Agama Bagi Anak dari Pasangan Beda Agama dalam Persepektif Hak Asasi Manusia, Skripsi, (Jakarta: UIN Syarif Hidayatullah, 2008), h.55.

${ }^{23}$ Ahmad Kosasih, HAM dalam Perspektif Islam, h.40. 


\begin{tabular}{|c|c|c|}
\hline & HAM UDHR/DUHAM (BARAT) & HAM ISLAM \\
\hline 1. & Bersumber pada pemikiran filosofis semata & $\begin{array}{l}\text { 1. Bersumber pada ajaran al-Quran dan sunah Nabi } \\
\text { Muhamad SAW. }\end{array}$ \\
\hline 2. & Bersifat Antrophocentris & 2. Bersifat Theocentris. \\
\hline 3. & Lebih mementingkan hak dari pada kewajiban & 3. Keseimbangan antara hak dan kewajiban \\
\hline 4. & Lebih bersifat individualistik & 4. Kepentingan sosial lebih diutamakan \\
\hline 5. & $\begin{array}{l}\text { Manusia sebagai pemilik sepenuhnya hak-hak } \\
\text { dasar. }\end{array}$ & $\begin{array}{l}\text { 5. Manusia sebagai makhluk yang dititipi hak-hak dasar } \\
\text { oleh Tuhan, oleh karena itu wajib mensyukuri dan } \\
\text { memeliharanya. }\end{array}$ \\
\hline
\end{tabular}

\section{Prinsip-prinsip HAM dalam Piagam Madinah}

Hak asasi manusia dalam kitab-kitab hadits shahih, hasan, dan musnadmusnad, tidak hanya satu bentuk, diantaranya bahwasanya Nabi shallallahu 'alaihi wa sallam bersabda dalam khutbah haji Wada':

"Sesungguhnya darah kalian, harta-harta kalian, dan kehormatan-kehormatan kalian itu haram (mulia-dilindungi) atas kalian seperti haramnya (mulianyadilindunginya) hari kalian ini di bulan kalian ini di negeri kalian ini". (Tafsir Ibnu Katsir juz 4 hal 215, Shahih Al-Bukhari no 105, dan Shahih Muslim no 1218).

Khutbah wada' sampai sekarang dikenal sebagai khutbah perpisahan Nabi Muhammad SAW dengan umatnya di seluruh dunia dengan meneguhkan kesempurnaan risalah Islam yang di ajarkanya. Dalam khutbah atau pidato yang bertepatan dengan pelaksanaan wukuf di Arafah pada tanggal 9 Dzulhijjah 11 Hijriyah tersebut, terdapat hal lain yang penting bagi kehidupan umat manusia di muka bumi yaitu komitemen Islam yang menjunjung nilai-nilai hak asasi manusia.

Piagam Madinah (Bahasa Arab: shahifatul madinah) juga dikenal dengan sebutan Konstitusi Madinah, ialah sebuah dokumen yang disusun oleh Nabi Muhammad SAW, yang merupakan suatu perjanjian formal antara dirinya dengan semua suku-suku dan kaum-kaum penting di Yatshrib (kemudian bernama Madinah) pada tahun 622 Masehi. Para ahli menyebut naskah yang di buat Nabi Muhammad saw itu dengan nama yang bermacam macam. W.Montgomery Watt menamainya "The Constitution of Medina", R.A. Nicholson “Charter," Majid Khaddury "Treaty," Phillip K. Hitti "Agreement." 24 Dalam tulisan ini digunakan Sebutan "Piagam Madinah." Kata piagam menunjuk pada naskah. Kata Madinah menunjuk kepada tempat dibuatnya. Piagam berarti surat resmi yang berisi tentang pernyataan tentang sesuatu hal. ${ }^{25}$

${ }_{24}$ Ahmad Sukardja, Piagam Madinah dan UUD NRI 1945, (Jakarta: Sinar Grafika, 2012), h.2.

${ }_{25}$ KBBI, 2005, h. 680. di akses dari www.pusatbahasa.kemdiknas.go.id/kbbi/, pada 12 Januari 2017 jam 22.00 . 
Piagam Madinah juga disusun dengan tujuan utama untuk menghentikan pertentangan sengit antara Bani 'Aus dan Bani Khazraj di Madinah. Untuk itu dokumen tersebut menetapkan sejumlah hak-hak dan kewajiban-kewajiban bagi kaum Muslim, kaum Yahudi, dan komunitas penyembah berhala di Madinah; sehingga membuat mereka menjadi suatu kesatuan komunitas, yang dalam bahasa Arab disebut ummah.

Piagam Madinah terdiri dari 47 pasal yang terdiri dari hal Mukadimah, dilanjutkan oleh hal-hal seputar Pembentukan umat, Persatuan seagama, Persatuan segenap warga negara, Golongan minoritas, Tugas Warga Negara, Perlindungan Negara, Pimpinan Negara, Politik Perdamaian dan penutup. Disinilah kita bisa melihat peran dan fungsi Muhammad sebagai seorang negarawan sekaligus seorang pemimpin negara yang besar dan berkualitas sepanjang sejarah peradaban manusia, disamping posisi beliau selaku seorang Nabi dan Rasul secara keagamaan. Prinsip-prinsip hak asasi manusia dalam Piagam Madinah adalah: Pertama, interaksi secara baik dengan sesama, baik pemeluk islam maupun non muslim. Kedua, saling membantu dalam menghadapi musuh bersama. Ketiga, membela mereka yang teraniaya. Keempat, saling menasehati. Dan kelima, menghormati kebebasan beragama. Piagam madinah merupakan landasan bagi kehidupan masyarakat yang plural di Madinah. Berikut adalah substansi dari Piagam Madinah:

1. Monotheisme, yaitu mengakui adanya satu tuhan. Prinsip ini terkandung dalam Mukadimah, pasal 22,23 dan 42.

2. Persatuan dan kesatuan (pasal 1,15,17,25 dan 37). Dalam pasal-pasal ini ditegaskan bahwa seluruh penduduk Madinah adalah satu umat. Hanya satu perlindungan, bila orang Yahudi telah mengakui Piagam ini, berarti berhak atas perlindungan keamanan dan kehormatan. Selain itu kaum Yahudi dan Muslim bersama sama memikul biaya perang.

3. Persamaan dan keadilan (pasal 1,12,15,16,19,22,23,24,37 dan 40). Pasalpasal ini mengandung prinsip bahwa seluruh warga Madinah berstatus sama di muka hukum dan harus menegakan hokum beserta keadilan tanpa pandang bulu.

4. Kebebasan beragama (pasal 25). Kaum Yahudi bebas menjalankan agama mereka sebagaimana juga umat Islam bebas menjalankan syariat Islam.

5. Bela negara (pasal 24,37,38 dan 44). Setiap penduduk Madinah yang mengakui Piagam Madinah mempunyai kewajiban yang sama untuk menjunjung tinggi dan membela Madinah dari serangan musuh baik dari luar maupun dari dalam

6. Pengakuan dan pelestarian adat kebiasaan (pasal 2-10).Dalam pasal-pasal ini disebutkan secara berulang bahwa seluruh adat kebiasaan yang baik di kalangan Yahudi harus diakui dan dilestarikn. 
Selain enam prinsip tersebut Ahmad Sukaradja menambahkan dua prinsip,yakni :

7. Supremasi syari'at (pasal 23 dan pasal 42). Dalam pasal pasal tersebut, penyelesaian perselisihan ditetapkan menurut ketentuan Allah dan keputusan Nabi Muhammad SAW.

8. Politik damai dan proteksi internal (pasal $17,36,37,39,40,41$ dan pasal 47 ) dan sikap perdamaian secara eksternal di tegaskan pada pasal $45 .{ }^{26}$

\section{Hak Asasi Manusia dalam Al-Quran}

Al-Quran sebagai sumber hukum dalam Islam memberikan penghargaan yang tinggi terhadap hak asasi manusia. Al-Quran sebagi sumber hukum pertama bagi umat Islam telah meletakan dasar dasar HAM serta kebenaran dan keadilan, jauh sebelum timbul pemikiran mengenai hal tersebut pada masyarakat dunia. Hal ini dapat dilihat ketentuan-ketentuan yang terdapat dalam al-Quran, antara lain:

1. Dalam al-Quran terdapat puluhan ayat tentang hidup, pemeliharaan hidup dan penyediaan sarana kehidupan, misalnya dalam surat alMaidah ayat 32:

“Oleh karena itu Kami tetapkan (suatu hukum) bagi Bani Israil, bahwa: Barangsiapa yang membunuh seorang manusia, bukan karena orang itu (membunuh) orang lain, atau bukan karena membuat kerusakan dimuka bumi, Maka seakan-akan Dia telah membunuh manusia seluruhnya. dan Barangsiapa yang memelihara kehidupan seorang manusia, Maka seolaholah Dia telah memelihara kehidupan manusia semuanya. dan Sesungguhnya telah datang kepada mereka Rasul-rasul Kami dengan (membawa) keterangan-keterangan yang jelas, kemudian banyak diantara mereka sesudah itu sungguh-sungguh melampaui batas dalam berbuat kerusakan dimuka bumi".

2. Alquran juga menjelaskan seratus lebih ayat tentang ciptaan dan makhluk-makhluk serta tentang persamaan dalam penciptaan, misalnya dalam surat al-Hujarat ayat 13.

3. Alquran telah mengetengahkan sikap menentang kezaliman dan orangorang yang berbuat zalim dalam ratusan ayat, dan sebaliknya juga memerintahkan berbuat adil dalam puluhan ayat yang diungkapkan dengan kata: adl, qisth dan qishsh. ${ }^{27}$

${ }^{26}$ Eggi Sudjana, HAM dalam Perspektif Islam, (Jakarta: Nuansa Madani, 2003), h.89.

${ }^{27}$ Fatthurrahman li Tholibil Quran 
4. Dalam Alquran terdapat puluhan ayat yang berbicara mengenai larangan memaksa untuk menjamin kebebasan berfikir, berkeyakinan dan mengutarakan aspirasi, misalnya yang dikemukakan dalam surat al-Kahfi ayat 29 .

5. Beberapa ayat lain yang menunjukkan penghormatan HAM dalam ajaran Islam antara lain, Hak Persamaan dan Kebebasan (QS. al-Isra: 70, an-Nisa: 58, 105, 107, 135 dan al-Mumahanah: 8). Hak Hidup (QS. al-Maidah: 45 dan al-Isra: 33). Hak Perlindungan Diri (QS. al-Balad: 12-17, at-Taubah: 6). Hak Kehormatan Pribadi (QS. at-Taubah: 6). Hak Keluarga (QS. alBaqarah: 221, ar-Rum: 21, an-Nisa 1, at-Tahrim: 6). Hak Keseteraan Wanita dan Pria (QS. al-Baqarah: 228 dan al-Hujrat: 13). Hak Anak dari Orangtua (QS. al-Baqarah: 233 dan surah al-Isra: 23-24). Hak Mendapatkan Pendidikan (QS. at-Taubah: 122, al-Alaq: 1-5). Hak Kebebasan Beragama (QS. al-kafirun: 1-6, al-Baqarah: 136 dan al-Kahti: 29). Hak Kebebasan Mencari Suaka (QS. an-Nisa: 97, al-Mumtahnah: 9). Hak Memperoleh Pekerjaan (QS. at-Taubah: 105, al-Baqarah: 286, al-Mulk: 15). Hak Memperoleh Perlakuan yang Sama (QS. al-Baqarah 275-278, AnNisa 161, al-Imran: 130). Hak Kepemilikan (QS. al-Baqarah: 29, an-Nisa: 29). Dan Hak Tahanan (QS. al-Mumtahanah: 8).

\section{Hak Asasi Manusia dalam Hadis}

Uraian-uraian berikut merupakan sebagian dari nilai-nilai Hak Asasi Manusia dan Keadilan dalam perspektif hadis yang ditemukan di dalam literatur-literatur hadis:

\section{Hak Hidup}

Di dalam hadits yang diriwayatkan oleh Bukhari menyebutkan, bahwa dosa terbesar kedua setelah menyekutukan Allah adalah membunuh anak kandung dikarenakan takut tidak bisa memberikannya makan. (an taqtula waladaka khasyyata an yath'ama ma'aka). ${ }^{28}$ Hanya saja pada zaman nabi dahulu hak-hak anak tidak terakomodir menjadi sebuah lembaga seperti dunia sekarang ini dengan adanya komisi nasional Hak Asasi Manusia Anak. Belum lagi watak orang Arab sangat benci dengan anak perempuan, sehingga anak perempuan bagi mereka adalah sebuah aib. Oleh karena itu, Islam datang untuk melidungi anak-anak.

Pada riwayat lain, tidak secara khusus atas anak-anak, yakni dengan redaksi yang lebih umum qatlu an-nas (membunuh manusia) adalah bagian dari rangkaian dosa besar (al-Kabair). ${ }^{29}$ Untuk menindak lanjuti undang-undang

28 Al-Bukhari, Shahih al-Bukhari, (Beirut: Dar al-Kotob al-Ilmiyah, 2013), ed. Mahmud Muhammed Nassar, cet. VII, h. 1245. Hadis No: 6861, 4471.

${ }^{29}$ Al-Bukhari, Shahih al-Bukhari, h. 1246. Hadis No: 6871. 
pembunuhan itu, yakni dengan hukum qishash yang secara sharih sudah termuat di dalam Alquran. Di samping itu kepemilikan senjata secara legal juga dinilai oleh Nabi bahwa orang yang memiliki senjata, maka bukan bagian dari kita (orang Muslim). ${ }^{30}$

Lebih dari itu, kematian manusia pun tetap dihormati oleh Nabi meskipun itu jenazah orang non-Muslim. Suatu hari pernah ada jenazah Yahudi yang hendak dimakamkan, kemudian Nabi berdiri untuk menghormatinya. Ketika itu Sahl bin Hunaif dan Qays bin Sa'd ikut berdiri dan memberi tahu kepada nabi bahwa jenazah tersebut adalah Yahudi. Nabi menjawab "alaisat nafsan?" bukankah ia juga manusia?. ${ }^{31}$ Mafhum mukhalafahnya, Nabi menghormati jenazah yahudi, apalagi kalau masih hidup?.

Hal ini menunjukkan bahwa menghormati orang lain tidak pandang agama atau apapun atributnya, sebagai seorang manusia harus menghormati dengan yang lainnya.

\section{Hak Persamaan Keadilan}

Hak keadilan nilai universal ketika hukum benar-benar ditegakkan, maka tidak akan pandang bulu. Meskipun ketika yang melanggar adalah sanak saudaranya sendiri. Maka keadilan tetap ditegakkan dengan adil sesuai dengan aturan-aturannya. Sebagaimana Nabi Muhammad pernah bersabda: "Seandainya Fatimah mencuri, maka aku sendiri yang akan memotong tangannya." 32 Ini merupakan suri tauladan yang diberikan oleh Nabi bahwa sebaiknya di dalam melaksanakan tindakan hukum tidak ada pengecualian.

\section{Hak Menuntut Ilmu}

Islam sangat menghargai ilmu, dalam suatu hadits Nabi menceritakan tentang kisah Musa, bahwa Musa pernah menyombongkan diri kepada kaum bani Israil ketika ia ditanya "adakah orang yang lebih tahu dari pada engkau, Musa?." Ia menjawab "Tidak ada." Kemudian Allah menegurnya "Ada, yaitu hamba-Ku Khadr" ${ }^{33}$. Lalu Musa merantau untuk mencari Khadr guna menimba ilmu darinya, walaupun akhirnya ia gagal dalam mempelajari ilmu sabar. Lalu kisah ini diabadikan oleh Alquran di dalam QS. al-Kahfi: 60-82.

30 "Man hamala 'alaina as-silah fa laisa minna". Shahih al-Bukhari, h. 1246. Hadits no: 6874, 7070.

${ }^{31}$ Al-Bukhari, Shahih al-Bukhari, h. 243. Hadis No: 1312.

${ }_{32}$ Muslim an-Naisaburi, Shahih Muslim. Hadis No: 4505, h.114. Di akses dari Maktabah Syamilah.

${ }^{33}$ Al-Bukhari, Shahih al-Bukhari, h. 33. Hadis No: 74 dan 78. 
Di dalam hadits lain Nabi bersabda bahwa "Berpikir selama satu jam lebih berguna dari pada beribadah satu tahun." ${ }^{34}$ Dalam riwayat lain lebih baik dari memerdekakan seribu budak. Bahkan, ketika tidak ada lagi yang menuntut ilmu dan kebodohan di mana-mana, maka itu merupakan salah satu tanda-tanda dekatnya hari kiamat. ${ }^{35}$

Melalui hadits-hadits di atas, pada dasarnya Islam tidak membatasi orang untuk mencari ilmu, baik laki-laki ataupun perempuan. Mereka semua sama dalam memperoleh hak untuk mendapatkan pendidikan secara setara. Jadi tidak ada pembatasan-pembatasan dalam menghalangi masyarakat untuk menuntut ilmu.

\section{Hak Kepemilikan}

Kepemilikan juga menjadi nilai yang sangat dihormati di dalam Islam, sehingga untuk memasuki rumah seseorang harus meminta izin dengan mengucapkan salam terlebih dahulu. Hal ini termaktub secara jelas di dalam QS. an-Nur: 27-29. Untuk menyikapi hal demikian, Nabi memberikan isyarat dengan hadits "Ketika kamu meminta izin sampai tiga kali, namun tidak dijinkan maka lebih baik kamu kembali (pulang)." 36

Hal ini tidak mencakup hanya di dalam ruang lingkup rumah saja, namun dalam segala hal kepemilikan. Sebab apabila tidak ada proses ijin terlebih dahulu, maka di dalam bahasa agama dinilai sebagai perbuatan ghasab, lebih dari itu bisa dinilai sebagai pencurian apabila sampai mengambil tanpa seijin pemiliknya.

\section{Maqoshid al-Syariah dalam HAM}

Prinsip-prinsip hak asasi manusia menjadi tujuan dari syariat Islam (maqoshid al-Syaria'at) yang telah dirumuskan oleh Imam al-Ghazali dan Abu Ishaq as-Syatibi Prinsip tersebut terangkum dalam dalamal-dlaruriat alkhamsah (lima prinsip dasar) atau disebut juga al huquq al insaniyah fi al Islam (hak asasi manusia dalam Islam). Konsep ini mengandung lima prinsip dasar yang harus di jaga dan di hormati oleh setiap individu, yakni: ${ }^{37}$

1. Hifdzu al-Din (penghormatan atas kebebasan beragama)

Islam memberikan penghormatan dan kebebasan berkeyakinan dan beribadah. Setiap pemeluk agama berhak atas agama dan mazhabnya. Seseorang tidak boleh dipaksa untuk meninggalkan agamanya menuju agama atau

\footnotetext{
${ }^{34}$ Nawawi al-Bantani, Tanqihu al-Qaulu al-Haidits Syarhu Lubabu al-Hadits, (Semarang: Toha Putra, tth), h.7.

35 Al-Bukhari, Shahih al-Bukhari, h.33. Hadis No: 88, 5577, 6808.

36 Al-Bukhari, Shahih al-Bukhari, h. 1143. Hadis No: 6245.

${ }^{37}$ Ahmad al-Mursi Husain Jauhar, Maqoshid Syariat, (Jakarta: Azmah, 2009), h. 15.
} 
madzhab lainya dan tidak seorangpun boleh memaksa dan menekan orang lain untuk berpindah dari keyakinanya untuk masuk Islam. Hal ini tergambar dalam al-Quran surat al-Baqarah ayat 256 yang artinya "Tidak ada paksaan (dalam) menganut agama (Islam)."

\section{Hifdzu al-Mal (penghormatan atas harta benda)}

Dalam ajaran Islam harta adalah milik Allah SWT yang dititipka-Nya pada Alam dan manusia sebagai anugerah. Seluruh bumi beserta segala yang terkandung di dalamnya, dan apa yang berada di atasnya telah dijadikan Allah SWT untuk seluruh manusia. Sebagaimana firman Allah dalam al-Quran surat ar-Rahman ayat 10 yang artinya:"Dan Allah telah meratakan bumi untuk makhlukNya." Dan juga dalam surat al-Hadid ayat 7 yang mengatakan:

“Berimanlah kamu kepada Allah dan Rasul-Nya dan nafkahkanlah sebagian dari hartamu yang Allah telah menjadikan kamu menguasainya. Maka orang-orang yang beriman di antara kamu dan menafkahkan (sebagian) dari hartanya memperoleh pahala yang besar.

3. Hifdzu al-Nafs wa al-'Ird (penghormatan atas jiwa, hak hidup dan kehormatan individu)

Dalam ajaran Islam, penghormatan atas jiwa, hak hidup dan kehormatan individu merupakan hak dasar dan tumpuan dari semua hak. Hak-hak lain tidak akan ada dan relevan tanpa perlindungan hak hidup. Maka perlindungan alQuran terhadap hak ini sangat jelas dan tegas seperti disebutkan dalam surat alMaidah ayat 32:

“Oleh karena itu Kami tetapkan (suatu hukum) bagi Bani Israil, bahwa: Barangsiapa yang membunuh seorang manusia, bukan karena orang itu (membunuh) orang lain, atau bukan karena membuat kerusakan dimuka bumi, Maka seakan-akan Dia telah membunuh manusia seluruhnya. Dan Barangsiapa yang memelihara kehidupan seorang manusia, Maka seolah-olah Dia telah memelihara kehidupan manusia semuanya. dan Sesungguhnya telah datang kepada mereka Rasul-rasul Kami dengan (membawa) keterangan-keterangan yang jelas, kemudian banyak diantara mereka sesudah itu sungguhsungguh melampaui batas dalam berbuat kerusakan dimuka bumi".

Karena penghargaan yang tinggi terhadap jiwa dan kehidupan maka al Quran memberikan sangsi yang tegas terhadap siapapun yang mengingkarinya. Qishas atau hukuman mati terlahir dari spirit perlindungan ini. Al-Quran menegaskan: "Dan dalam qishaash itu ada (jaminan kelangsungan) hidup bagimu, Hai orang-orang yang berakal, supaya kamu bertakwa." (Q.S. al-Baqaroh ayat 179). 
4. Hifdzu al-'Aql (penghormatan atas kebebasan berfikir)

Penghormatan atas kebebasan berfikir serta hak atas pendidikan merupakan penjabaran yang amat penting dari prinsip hifdz al-aql. Menjaga akal budi dari zat-zat yang memabukan merupakan perlindungan primer, maka pendidikan merupakan pemenuhan hak-hak sekunder untuk pengembanganya. Tanpa pendidikan yang memadai akal sebagai anugerah penting dari Tuhan kurang bernilai dan menyia-nyiakan anugerah Tuhan.

\section{Hifdzu al-Nasl (keharusan untuk menjaga keturunan)}

Dalam ajaran Islam menjaga dan memelihara keturunan di manifestasikan dengan disyariatkan lembaga pernikahan. Islam memandang lembaga pernikahan sebagai cara melindungi eksistensi manusia secara terhormat dan bermartabat. Islam tidak menganjurkan, meski tidak mengharamkan secara mutlak hidup celibat/membujang. Bagi yang menjalankan pernikahan secara penuh tanggungjawab dijanjikan dengan kemuliaan. Sebab dengan pernikahan yang penuh tanggungjawab dan harmonis, generasi manusia yang saleh dapat dibina dari satu generasi kegenerasi secara berkesinambungan. Pernikahan merupakan peristiwa kontraktual dan sakral. Hampir setiap keyakinan agama termasuk ajaran Islam mengatur secara serius mengurus pernikahan sampai detail, bukan sekedar syarat dan rukunnya melainkan sekaligus prosesinya. Memiliki keturunan melalui jalinan pernikahan yang sah untuk melanjutkan keturunan manusia secara terhormat dan bermartabat.

\section{Kesimpulan}

Berdasarkan pembahasan di atas dapat kita simpulkan bahwa respon Islam terhadap hak asasi manusia adalah cerminan dari tuntutan global, abadi dan fundamental. Dengan tidak bermaksud untuk berapologi, sesunguhnya Islam telah terlebih dahulu mengajarkan umat manusia tentang konsep yang egaliter, universal dan demokratis. Konsep yang sedemikian indah dan komprehensif ini disinyalir diadopsi oleh Barat melalui pemunculan ide-ide universal yang dibakukan dalam konvensi Universal Declaration of Human Rights.

Islam adalah agama yang asy-Syumul. Ajaran Islam meliputi seluruh aspek dari sisi kehidupan manusia. Islam memberikan pengaturan dan tuntutan pada manusia, mulai dari urusan yang paling kecil hingga urusan yang berskala besar. Dan tentu saja telah tercakup di dalamnya aturan dan penghargaan yang tinggi terhadap hak asasi manusia (HAM). Namun memang tidak dalam satu dokumen yang terstruktur, tetapi tersebar dalam ayat-ayat suci al-Quran dan Sunnah Nabi Muhammad Saw. 
Kelahiran IUDHR dan Cairo Declaration on Human Rights in Islam (CDHRI) yang diratifikasi oleh OKI sesungguhnya merupakan upaya penjernihan yang dilakukan oleh negara-negara Muslim atas klaim Barat yang arogan, otoriter dan semena-mena.

\section{Daftar Pustaka}

Abdillah, Masykuri. Responses of Indonesian Muslim Intellectuals to the Concept of Democracy (1966-1993), terj. Wahib Wahab, (Yogyakarta: Tiara Wacana, 1999).

Aji, Ahmad Mukri. Kontekstualisasi Ijtihad Dalam Diskursus Pemikiran Hukum Islam di Indonesia, Bogor: Pustaka Pena Ilahi, 2010.

Aji, Ahmad Mukri. Urgensi Maslahat Mursalah Dalam Dialektika Pemikiran Hukum Islam, Bogor: Pustaka Pena Ilahi, 2012.

Al-Bantani, Nawawi. Tanqihu al-Qaulu al-Haidits Syarhu Lubabu al-Hadits, (Semarang: Toha Putra, tth).

Al-Bukhari, Shahih al-Bukhari, Beirut: Dar al-Kotob al-Ilmiyah, 2013), ed. Mahmud Muhammed Nassar, cet. VII, h. 1245. Hadis No: 6861, 4471

Aripin, Jainal. Dkk, Kumpulan Hasil Penelitian 2002, Hak Asasi Manusia dalam Tinjauan Islam dan Implementasi di Indonesia.

Azazi, Hak Memilih Agama Bagi Anak dari Pasangan Beda Agama dalam Persepektif Hak Asasi Manusia, Skripsi, (Jakarta: UIN Syarif Hidayatullah, 2008).

Budiardjo, Miriam. Dasar-dasar Ilmu Politik, Jakarta: Gramedia Pustaka Umum, 2000 .

Hardjowirogo, Marbangun. HAM dalam Mekanisme-mekanisme Perintis Nasional, Regional dan Internasional, Bandung: Patma, 1977.

Hussain, Syaukat. Hak Asasi Manusia Dalam Islam, Penerjemah: Abdul Rochim, Jakarta: Gema Insani press, 1996.

Jauhar, Ahmad al-Mursi Husain. Maqoshid Syariat, Jakarta: Azmah, 2009.

Khallaf, Abd. Wahab. Ilm Ushul al-Figh, Kuwait: Dar al-Qalam, 1978.

Kosasih, Ahmad. HAM Dalam perspektif Islam, Jakarta: Salemba Diniyah, 2003.

Maggalatung, A Salman; Yunus, Nur Rohim. Pokok-Pokok Teori Ilmu Negara, Cet1, Bandung: Fajar Media, 2013.

Mufti, Muhamad A; dan Al-Wakil, Sami Salih. HAM Menurut Barat dan HAM menurut Islam terj. Yahya Abd Rahman, Bogor: Pustaka Thariqul Izzah, 2009.

Muhammad, Rusjidi Ali, Hak Asasi Manusia dalam Perspektif Syari'at Islam, Aceh: Ar-Raniri Press, 2004. 
Pendidikan Kewarganegaraan (Civic Education) Demokrasi, HAM dan Masyarakat Madani, Jakarta: IAIN Press, 2000.

Pendidikan Kewarnageraan (Civic Education) Demokrasi, HAM, dan Masayarakat Madani, Jakarta: ICCE UIN Syarif Hidayatullah, 2003.

Sudjana, Eggi. HAM dalam Perspektif Islam, Mencari Universalitas HAM bagi Tatanan Modersitas yang Hakiki, Jakarta: Nuansa Madani, 2000.

Sukardja, Ahmad. Piagam Madinah dan UUD NRI 1945, Jakarta: Sinar Grafika, 2012.

Yunus, Nur Rohim. Restorasi Budaya Hukum Masyarakat Indonesia, Bogor: Jurisprudence Press, 2012.

Jurnal:

Aji, Ahmad Mukri. "Pemberatasan Tindak Pidana Terorisme di Indonesia (Analisis Terhadap Undang-Undang Nomor 15 dan 16 Tahun 2003 Berdasarkan Teori Hukum)," dalam Jurnal Cita Hukum, Vol. 1, No. 1 (2013).

Asnawi, Habib Shulton. "Hak Asasi Manusia Islam dan Barat: Studi Kritik Hukum Pidana Islam dan Hukuman Mati," Jurnal Supremasi Hukum, Vol. 1, No. 1, Juni 2012.

Hamdani, Muhammad Faisal, "Hukum Keluarga Islam dalam Perspektif HAM Universal (UDHR) dan HAM Islam (UIDHR)," Jurnal Ahkam: Vol. xvi, No. 1, Januari 2016.

Ismail, "Hak Asasi Manusia Menurut Perspektif Islam," Jurnal Asy-Syir'ah, Vol. 43 No. I, 2009.

Maggalatung, A Salman. "Hubungan Antara Fakta Norma, Moral, Dan Doktrin Hukum Dalam Pertimbangan Putusan Hakim," dalam Jurnal Cita Hukum, Vol. 2, No. 2 (2014).

\section{Internet:}

KBBI, 2005, h. 680. di akses dari www.pusatbahasa.kemdiknas.go.id/kbbi/, pada 12 Januari 2017 jam 22.00 .

Undang-Undang No. 39 Tahun 1990 tentang Hak Asasi Manusia Pasal 1, di akses dari www.komisiyudisial.go.id, pada hari Kamis, 12 Januari 2017. 
Korelasi Hak Asasi Manusia dan Hukum Islam 


\title{
Pola Perlindungan Anak Di Negara-Negara Muslim* (Pattern of Child Protection in Muslim Countries)
}

\author{
Resti Hedi Juwanti ${ }^{1}$ \\ Magister Hukum Keluarga FSH \\ Universitas Islam Negeri Syarif Hidayatullah Jakarta \\ doi $\underline{10.15408 / \operatorname{sjsbs.v} 4 \mathrm{i} 1.7867}$
}

\begin{abstract}
.
Maintenance of child welfare cannot be carried out by the child itself, because in essence children cannot protect themselves from various types of actions that cause mental, physical, social harm in various fields of life and livelihood. So that opportunities, maintenance and efforts to eliminate these obstacles will only can be done and obtained if the child welfare effort is guaranteed. Therefore, children must be helped by others in protecting themselves. Thus, the author would like to discuss more about the concept of child protection in Indonesia, Malaysia, Egypt and Qatar, and the position of the Convention on the Rights of the Child for the legislation of the State. The research method that the author is doing is qualitative research with a normative approach and comparative methods of law. The data collection techniques were carried out with a literature review sourced from the Convention on the Rights of the Child and the Child Protection Act in Indonesia, Malaysia, Egypt and Qatar.
\end{abstract}

Keywords: Convention on the Rights of the Child, Protection of the Rights of the Child, Muslim Countries

\begin{abstract}
Abstrak.
Pemeliharaan kesejahteraan anak belum dapat dilaksanakan oleh anak itu sendiri, karena pada hakikatnya anak tidak dapat melindungi diri sendiri dari berbagai macam tindak yang menimbulkan kerugian mental, fisik, sosial dalam berbagai bidang kehidupan dan penghidupan, sehingga kesempatan, pemeliharaan dan usaha menghilangkan rintangan tersebut hanya akan dapat dilakukan dan diperoleh bilamana usaha kesejahteraan anak terjamin. Oleh karena itu, anak harus dibantu oleh orang lain dalam melindungi dirinya. Dengan demikian, penulis ingin membahas lebih lanjut tentang konsep perlindungan anak di Negara Indonesia, Malaysia, Mesir dan Qatar, serta kedudukan Konvensi Hak Anak bagi perundangundangan Negara tersebut. Metode penelitian yang penulis lakukan adalah penelitian kualitatif dengan pendekatan normatif serta metode perbandingan hukum. Adapun teknik pengumpulan data dilakukan dengan kajian kepustakaan yang bersumber dari Konvensi Hak Anak dan Undang-Undang Perlindungan Anak di Negara Indonesia Malaysia, Mesir dan Qatar.
\end{abstract}

Kata Kunci: Konvensi Hak Anak, Perlindungan Hak Anak, Negara Muslim

* Diterima tanggal naskah diterima: 14 Desember 2017, direvisi: 21 Maret 2017, disetujui untuk terbit: 24 April 2017.

1 Penulis adalah Peneliti pada Fakultas Syariah dan Hukum, Universitas Islam Negeri (UIN) Syarif Hidayatullah Jakarta. Jl. Ir. H. Juanda No. 95 Ciputat Tangsel. E-mail: restihedijuwanti@uinjkt.ac.id. 


\section{Pendahuluan}

Anak adalah bagian dari generasi muda sebagai salah satu sumber daya manusia yang merupakan potensi dan penerus cita-cita perjuangan bangsa, yang memiliki peranan strategis dan mempunyai ciri dan sifat khusus, memerlukan pembinaan dan perlindungan dalam rangka menjamin pertumbuhan dan perkembangan fisik, mental dan sosial secara utuh, serasi, selaras dan seimbang. Untuk melaksanakan pembinaan dan memberikan perlindungan terhadap anak, diperlukan dukungan, baik yang menyangkut kelembagaan maupun perangkat hukum yang lebih mantap dan memadai.

Pemeliharaan kesejahteraan anak belum dapat dilaksanakan oleh anak itu sendiri, karena pada hakikatnya anak tidak dapat melindungi diri sendiri dari berbagai macam tindakan yang menimbulkan kerugian mental, fisik, sosial dalam berbagai bidang kehidupan dan penghidupan, sehingga kesempatan, pemeliharaan dan usaha menghilangkan rintangan tersebut hanya akan dapat dilakukan dan diperoleh bilamana usaha kesejahteraan anak terjamin, oleh karena itu anak harus dibantu oleh orang lain dalam melindungi dirinya.

Dalam rangka terjaminnya perlindungan hak anak, maka diperlukan kesadaran dari lingkungan sang anak hidup, baik lingkungan keluarga, sekolah, maupun masyarakat. Tidak hanya kesadaran, sebuah aturan juga diperlukan untuk perlindungan hak anak. Adapun pihak yang berkewajiban dalam mengadakan aturan tersebut adalah Negara. Negara harus memiliki lembaga dalam pembentukan dan melaksanakan aturan tersebut, agar apa yang dicitakan dapat terlaksana dengan baik dan terkontrol.

\section{Konvensi Hak Anak}

Setiap manusia memiliki hak dasar yang harus terpenuhi selama masa hidupnya. Tak terkecuali seorang anak yang terhitung sejak lahir hingga berusia 18 tahun pun memiliki hak-hak khusus yang harus dilindungi. Hak-hak tersebut telah dirumuskan dalam sebuah aturan oleh lembaga dunia yaitu Perserikatan Bangsa-Bangsa (PBB), lalu disahkan pada tanggal 20 November 1989. Hak-hak tersebut dirumuskan dalam Kovensi Hak Anak (Convention of Rights of The Child).

Adapun pokok-pokok materi hukum yang terkandung dalam Konvensi tersebut dapat dikategorikan menjadi 4 bagian, sebagai berikut: ${ }^{2}$

1) Hak terhadap kelangsungan hidup, yaitu hak-hak anak dalam konvensi hak anak yang meliputi hak-hak untuk melestarikan dan

2 Muhammad Joni dan Zulchaina Z. Taramas, Aspek Hukum Perlindungan Anak dalam Perspektif Hak Anak, (Bandung: PT. Citra Aditya Bakti, 1999), h.35. 
mempertahankan hidup dan hak untuk memperoleh standar kesehatan tertinggi dan perawatan yang sebaik-baiknya.

2) Hak terhadap perlindungan, yaitu hak-hak anak dalam konvensi hak anak yang meliputi hak perlindungan dari diskriminasi, tindak kekerasan dan keterlantaran bagi anak yang tidak mempunyai keluarga dan bagi anak-anak pengungsi.

3) Hak untuk tumbuh kembang, yaitu hak-hak anak dalam konvensi hak anak yang meliputi segala bentuk pendidikan (formal dan non formal) dan hak untuk mencapai standar hidup yang layak bagi perkembangan fisik, mental, spiritual, moral dan sosial anak.

4) Hak untuk berpartisipasi, yaitu hak-hak anak dalam konvensi hak anak yang meliputi hak-hak untuk menyatakan pendapat dalam segala hal yang mempengaruhi anak.

Pada tanggal 2 september 1990, konvensi ini mulai mempunyai kekuatan memaksa agar setiap Negara yang menjadi peserta dalam PBB menandatangani dan meratifikasi konvensi tersebut. pada tanggal 26 November 2008 telah dirilis data terbaru terkait Negara-negara yang telah menandatangani dan meratifikasi. 191 negara peserta telah menandatangani dan meratifikasi konvensi tersebut, hanya Amerika Serikat dan Somalia yang sudah menandatangani tetapi belum meratifikasi. ${ }^{3}$

Dari jumlah Negara tersebut, ada beberapa Negara muslim yang ikut meratifikasi konvensi tersebut, antara lain seperti Negara Indonesia, Malaysia, Mesir, Qatar dan Negara lainnya. Pada makalah ini akan dibahas konsep perlindungan anak di Negara-negara muslim tersebut.

\section{1) Indonesia}

Kovensi hak anak merupakan sumber hukum yang memberikan materi pada pembuatan hukum dan harmonisasi hukum tentang anak. Kaidah hukum yang terdapat dalam konvensi hak-hak anak merupakan materi hukum yang memberi isi peraturan perundang-undangan tentang anak, oleh karena itu konvensi hak anak menjadi bagian integral dari hukum tentang anak.

Sebagai perwujudan komitmen pemerintah dalam meratifikasi konvensi hak anak, maka pada tanggal 22 oktober 2002, pemerintah mengesahkan UU No. 23 Tahun 2002 tentang perlindungan anak yang berorientasi pada hak-hak anak seperti yang tertuang dalam konvensi hak-hak anak. Oleh karena itu dalam ketentuan hukum nasional sebelum disahkannya UU No. 23 Tahun 2002, perlindungan hak asasi anak sebelumnya sudah diatur dalam UU No. 39 Tahun

\footnotetext{
${ }^{3}$ Child Right Information Network (2008). Convention on the Rights of the Child. Diakses pada tanggal 3 November 2016.
} 
1999 Tentang Hak Asasi Manusia. Dalam UU No. 39 Tahun 1999 disebutkan bahwa hak-hak asasi manusia termasuk juga anak-anak, yaitu seseorang yang berusia dibawah 18 tahun dan belum menikah termasuk anak yang masih didalam kandungan harus dihormati dan mendapatkan perlindungan. ${ }^{4}$ Secara khusus perlindungan anak dalam lingkungan keluarga juga diatur dalam UU No. 23 Tahun 2004 tentang penghapusan kekerasan dalam rumah tangga. Dalam ketentuan pasal 2 disebutkan bahwa anak merupakan bagian dari keluarga yang harus mendapatkan perlindungan dari kekerasan secara fisik maupun psikis. ${ }^{5}$

Dalam UU No. 23 Tahun 2002 yang merupakan aturan cerminan dari konvensi hak-hak anak, mengatur terbentuknya sebuah badan yang menjadi ciri khas dalam penegakan hukum perlindungan anak di Indonesia, badan tersebut adalah Komisi Perlindungan Anak Indonesia (KPAI). Selain itu, ada pula lembaga Komisi Nasional (KOMNAS) Perlindungan Anak Indonesia. ${ }^{6}$

\section{Komisi Perlindungan Anak Indonesia (KPAI)}

Komisi ini terbentuk atas dasar UU No. 23 Tahun 2002 yang diatur pada pasal 74-76 dan melalui Keputusan Presiden No. 77 Tahun 2003. Komisi ini dibentuk dalam rangka menigkatkan efektivitas penyelenggaraan perlindungan anak. Adapun tugas-tugasnya sebagai berikut: ${ }^{7}$

1. Melakukan sosialisasi dan advokasi tentang peraturan perundangundangan yang berkaitan dengan perlindungan anak.

2. Menerima pengaduan dan memfasilitasi pelayanan masyarakat terhadap kasus-kasus pelanggaran hak anak kepada pihak-pihak yang berwenang.

3. Melakukan pengkajian peraturan perundang-undangan, kebijakan pemerintah, dan kondisi pendukung lainnya baik di bidang sosial, ekonomi, budaya, dan agama.

4. Menyampaikan dan memberikan masukan, saran, dan pertimbangan kepada berbagai pihak terutama presiden, DPR, instansi pemerintah terkait ditingkat pusat dan daerah.

5. Mengumpulkan data dan informasi tentang masalah perlindungan anak.

4 Muhammad Taufik Makarao dkk, Hukum Perlindungan Anak dan Penghapusan Kekerasan Dalam Rumah Tangga, (Jakarta: Rineka Cipta, 2013), h. 104-105.

5 Muhammad Taufik Makarao dkk, Hukum Perlindungan Anak dan Penghapusan Kekerasan Dalam Rumah Tangga, h. 174.

6 Muhammad Taufik Makarao dkk, Hukum Perlindungan Anak dan Penghapusan Kekerasan Dalam Rumah Tangga, h. 160.

${ }^{7}$ Muhammad Taufik Makarao dkk, Hukum Perlindungan Anak dan Penghapusan Kekerasan Dalam Rumah Tangga, h. 161-162. 
6. Melakukan pemantauan, evaluasi dan pelaporan tentang perlindungan anak termasuk laporan untuk Komita Hak Anak PBB.

7. Melakukan pengawasan terhadap penyelenggaraan perlindungan anak di Indonesia.

\section{Komisi Nasional (KOMNAS) Perlindungan Anak}

Komisi ini terbentuk pada tanggal 26 Oktober 1998 berasakan Pancasila dan berlandaskan Undang-Undang Dasar 1945. Komisi ini terbentuk sebagai hasil pencermatan permasalahan anak yang membutuhkan perhatian yang serius dari semua pihak baik keluarga, atas prakasa Departemen RI, tokoh masyarakat, perguruan tinggi, organisasi non-pemerintah dan pemerintah, media massa, dan kalangan profesi serta dukungan UNICEF. Adapun tugas-tugas KOMNAS Perlindungan Anak sebagai berikut: ${ }^{8}$

1. Melaksanakan mandat yang ditetapkan oleh Forum Nasional Perlindungan Anak

2. Menjabarkan Agenda Nasional Perlindungan Anak dalam program tahunan

3. Membentuk dan memperkuat jaringan kerja sama dalam upaya perlindungan anak, baik dengan LSM, masyarakat madani, instansi pemerintah, maupun lembaga internasional, pemerintah dan nonpemerintah

4. Menggali sumber daya dan dana yang dapat membantu peningkatan upaya perlindungan anak

5. Melaksanakan administrasi perkantoran dan kepegawaian untuk menunjang program kerja lembaga perlindungan anak.

\section{2) Malaysia}

Di Negara Malaysia masalah hak-hak anak sudah diatur dalam Akta Anak-anak 2001 (Akta 611). ${ }^{9}$ Anak-anak yang dilindungi di bawah akta 2001 ini terdiri dari: a) anak-anak yang merupakan pemeliharaan dan perlindungan, b) anak-anak yang memerlukan perlindungan dan pemulihan, c) perdagangan dan pelarian anak-anak, d) anak-anak yang melakukan kesalahan jinayah, e) anakanak yang tidak dikawal.

\footnotetext{
${ }^{8}$ Muhammad Taufik Makarao dkk, Hukum Perlindungan Anak dan Penghapusan Kekerasan Dalam Rumah Tangga, h. 164.

9 Lembaga Penyelidikan Undang-Undang, Akta Kanak-Kanak 2001 (Akta 611), (Kuala Lumpur: International Law Book Services, 2002).
} 
1. Anak-anak yang Memerlukan Pemeliharaan dan Perlindungan

Dalam Seksyen 17 (1) Akta 2001 memberikan pemahaman bahwa anakanak yang memerlukan pemeliharaan dan perlindungan adalah mereka yang menderita secara fisik, mental, diabaikan, anak-anak yang berkelakuan buruk, anak-anak yang orang tuanya mengalami perceraian juga anak-anak pengemis dan pedagang asongan. ${ }^{10}$

2. Anak-Anak yang Memerlukan Perlindungan dan Pemulihan

Seksyen 38 (1) Akta 2001 mentakrifkan golongan ini sebagai mereka yang melakukan perbuatan seks bebas, atau mereka yang berada dalam lingkungan yang membawa mereka pada perbuatan tersebut, tinggal atau kerap kali mengunjungi tempat-tempat pelacuran, atau mereka yang berada di bawah kendali penyelenggara tempat pelacuran. Selain golongan ini, seksyen 42 Akta 2001 juga mencantumkan anak-anak yang dibeli untuk dibawa masuk atau keluar dari Malaysia untuk tujuan pelacuran sebagai anak-anak yang juga memerlukan perlindungan dan pemulihan. ${ }^{11}$

3. Perdagangan dan Pelarian Anak-anak

Dalam seksyen 48 Akta 2001 menuliskan bahwa anak-anak yang menjadi korban penjualan di dalam atau di luar Malaysia sebagai mereka yang harus dilindungi, juga anak-anak yang disembunyikan oleh salah seorang dari ibu atau bapak atau pengasuh anak-anak tersebut yang tidak mempunyai hak asuh yang sah. ${ }^{12}$

4. Anak-Anak yang Melakukan Kesalahan Jinayah

Anak-anak boleh dipidanakan akan tetapi mewajibkan mahkamah bagi anak-anak harus berada di dalam penguasaan kecuali bagi pidana yang dijatuhkan hukuman mati.

5. Anak-anak yang Tidak Diasuh

Di dalam akta 2001 tidak ada penjelasan mengenai makna anak-anak yang tidak diasuh, akan tetapi dalam seksyen 46 (1) Akta 2001 dapat diambil kesimpulan bahwa anak-anak dikatakan tidak diasuh jika ibu bapak atau orang yang mengasuhnya membuat pernyataan tertulis kepada mahkamah bahwa ia tidak sanggup untuk mengasuh, maka anakanak tersebut diasuh oleh Negara.

10 Siti Zahara Jamaluddin, Akta Kanak-Kanak: Implikasinya Terhadap Ibu Bapa, Agensi Kerajaan, Badan Kehakiman dan Media, (Kuala Lumpur: University Malaya, 2002), h. 43.

11 Seksyen 2 (1) Akta 2001.

12 Seksyen 52 Akta 2001. 
Agar hak-hak anak tersebut dapat terlindungi dan terpenuhi, maka perlu adanya kerjasama antara orang tua atau keluarga, masyarakat juga tentunya Negara. Hal ini juga diatur dalam akta 2001 tentang Akta anak-anak.

1. Tanggung Jawab Orang Tua atau Keluarga.

Semakin rumitnya masalah sosial di masyarakat tentunya dipengaruhi oleh ketidakharmonisan di dalam keluarga. Akta 2001 menghimbau bahwa pentingnya peranan orang tua dalam mengatasi permasalahan ini. Akta ini menekankan tanggung jawab orang tua beserta keluarga terutama ketika anak sedang menghadapi masalah. Selain orang tua yaitu ibu dan bapak beserta keluarga, akta ini juga mendefinisikan keluarga sebagai orang yang mempunyai hubungan persaudaraan melalui pertalian darah, persemendaann atau pengangkatan dengan orang itu. ${ }^{13}$

2. Peranan Guru Besar

Akta 2001 juga memperkenalkan instansi pendidikan dalam membantu anak-anak yang bermasalah, Mahkamah membolehkan orang tua atau pengasuh anak untuk bermusyawarah dengan instansi pendidikan sebulan sekali. Mahkamah harus memastikan bahwa musyarawah tersebut berjalan sesuai aturan yang bertujuan untuk membantu anak. Selain itu memberitahukan kepada orang tua atau pengasuh tentang prestasi anak dan masalah-masalah yang dihadapi oleh anak serta memberi saran dalam menyelesaikan masalah tersebut. musyawarah ini harus dilakukan dengan serius bukan hanya sekedar formalitas saja. ${ }^{14}$

\section{Peranan Media}

Di Malaysia mahkamah untuk anak-anak merupakan suatu mahkamah yang tertutup, demi memastikan hal ini terpenuhi, berita dan penyiaran media tentang anak-anak tidak diperbolehkan untuk disiarkan, aturan ini dimasukkan ke dalam Akta 2001 demi memastikan hak anak-anak itu lebih terjain. ${ }^{15}$

4. Lembaga Pelindung

Sebagai seorang yang bekerja dalam lembaga ini, maka ia akan bertanggung jawab terhadap anak-anak yang memerlukan asuhan dan perlindungan (Seksyen 18 Akta 2001). Jika ia menemukan anak-anak yang memerlukan asuhan dan perlindungan, maka ia harus segera membawa anak tersebut ke mahkamah. Jika menurut lembaga pelindung

${ }^{13}$ Zulazhar Takir, Meninjau Isu Penderaan Kanak-Kanak dari Perspektif Akta Kanak-Kanak 2001, (Kuala Lumpur: Penerbit University Malaya, 2002), h. 85.

${ }^{14}$ Siti Zaharah Jamaluddin, Akta Kanak-kanak, (Kuala Lumpur: University Malaya, 2002), h. 66.

${ }^{15}$ Noor Aziah Mohd Awal, Child Act 2001 How Far Does it Conform to the UNCRC?, (Kuala Lumpur: Penerbit Universiti Malaya, 2002), h. 107. 
anak tersebut harus dirawat maka harus segera dilaksanakan. Lembaga pelindung juga diperlukan untuk memberikan laporan tentang anak-anak tersebut yang akan dipertimbangkan oleh mahkamah sebelum membuat keputusan (Seksyen 30 (6) Akta 2001). ${ }^{16}$

5. Pegawai Kebajikan Masyarakat

Seorang yang bekerja di dalam lembaga kebajikan masyarakat, disebut sebagai pegawai akhlak (Seksyen 10 Akta 2001). Ia bertugas menyediakan laporan perilaku bila diperlukan dan juga bertugas untuk mengawasi anak-anak (Seksyen 1 dan 2 AKta 2001). Dalam hal pengawasan anakanak, pegawai akhlak harus mengunjungi, menasehati dan bertindak layaknya teman kepada anak-anak tersebut (Seksyen 47 (1) (a) (b) Akta 2001. Peranan tersebut memerlukan jangka waktu yang panjang untuk mengenali dan mendapatkan kepercayaan anak-anak yang berada di bawah pengawasannya. ${ }^{17}$

6. Polis

Polis bertugas untuk membawa anak-anak yang memerlukan perawatan yang kemudian diasuh dan dilindungi dan kemudian diserahkan kepada lembaga pelindung (Seksyen 19 (5) Akta 2001). Anak-anak yang melakukan tindak pidana maka polis bertugas untuk menangkap lalu dibawa ke hadapan mahkamah (Seksyen 84 (1) Akta 2001. Semasa menjadi tahanan, polis harus memastikan bahwa anak-anak ini diasingkan dari orang dewasa baik sebelum ataupun sesudah dihadapkan kehadapan mahkamah (Seksyen 85 (a) Akta 2001).

Selain itu juga, pihak polis perlu memberitahukan kepada lembaga pelindung, orang tua atau pengasuh bahwa anak tersebut telah ditangkap karena telah melakukan perbuatan kriminal (Seksyen 87 (a) Akta 2001). Hal tersebut bertujuan untuk mempermudah pelindung dalam menyiapkan laporan yang diperlukan.

Peranan polis tersebut membantu pegawai kebajikan masyarakat dalam melindungi anak-anak, terutama disaat mereka memerlukan asuhan dan perlindungan. Terutama dalam kasus perdagangan dan pelarian anakanak (Seksyen 53 (3) (a) sampai (d) Akta 2001.18

16 Norchaya Talib, Siri Undang-Undang dari Akta Kanak-Kanak 2001, (Kuala Lumpur: University Malaya, 2002), h. 109.

${ }_{17}$ Norchaya Talib, Siri Undang-Undang dari Akta Kanak-Kanak 2001, h. 168.

18 Chew Li Hua, Criminal Prosedur Under Part X of the Child Act 2001, (Kuala Lumpur: University Malaya, 2003), h. 235. 


\section{3) Mesir}

\section{Status Hak Anak}

Mesir adalah salah satu Negara pertama yang menandatangani konvensi hak-hak anak. Konvensi hak anak mulai berlaku di Mesir pada tanggal 2 September 1990. Mesir menyatakan keberatannya pada pasal 20 dan 21 terkait untuk mendorong perawatan dan prosedur adopsi untuk anak-anak. Berikut rekomendasi dari komite hak anak yang menunjukkan bahwa konvensi hak anak dengan tegas mengakui kafalah dari hukum Islam sebagai bentuk alternative dari sebuah keperdulian. Pada tahun 2003 Mesir mengumumkan bahwa ia telah memutuskan untuk menarik penolakannya. ${ }^{19}$

Mesir menyetujui protokol opsional KHA tentang penjualan anak, prostitusi anak dan pornografi anak pada tahun 2003, dan protokol opsional tentang keterlibatan anak dalam konflik bersenjata pada tahun 2007. Negara ini juga telah menandatangani piagam Afrika tentang hak manusia dan masyarakat. Piagam afirka tentang hak dan kesejahteraan anak dan komisi Afrika tentang resolusi hak manusia dan masyarakat terkait situasi perempuan dan anak di Afrika. ${ }^{20}$

Penyerahan laporan awal tentang pelaksanaan KHA pada tanggal 23 Oktober 1992 dan laporan periode keduanya pada tanggal 18 September 1998. Koalisi LSM tentang hak-hak anak mengeluarkan laporan alternatif tentang hakhak anak. Setelah meninjau laporan kedua Mesir, Komite Hak Anak mencatat bahwa banyak rekomendasi dari laporan awal yang belum ditangani dan menemukan poin-poin yang sama, diantaranya sebagai berikut: ${ }^{21}$

1. Meningkatkan koordinasi tingkat sektoral dan kerjasama diantara tingkat nasional dan tingkat lokal pemerintahan.

2. Melibatkan masyarakat sipil khususnya asosiasi anak-anak dan kelompok advokasi dalam mengimplementasikan KHA.

3. Mempertimbangkan pembentukan lembaha HAM nasional yang independen untuk memantau dan mengevaluasi kemajuan dalam pelaksanaan KHA.

4. Meningkatkan usia pertanggungjawaban pidana yang saat ini ditetapkan pada usia tujuh tahun.

19 Yara Abdul Hamid, Child Rights Situation Analiesis For Middle East and North Africa Region, (Swedia: Menaregional Office, 2008), h. 34.

20 Child Information Network (CRIN), http;//www.crin.org/law/instrument.asp?instID=1157

21 Yara Abdul Hamid, Child Rights Situation Analiesis For Middle East and North Africa Region, h. 34. 
5. Melanjutkan upaya kampanye untuk mengurangi pernikahan pada usia dini dan pernikahan paksaan terutama di daerah pedesaan.

6. Mengambil langkah-langkah efektif untuk mencegah dan menghilangkan diskriminasi atas dasar jenis kelamin dan kelahiran di semua bidang kehidupan seperti sipil, ekonomi, politik, sosial dan budaya.

7. Mengatasi kesenjangan antar daerah dalam pembangunan sosial ekonomi.

8. Mengambil langkah-langkah legislatif untuk melarang segala bentuk kekerasan fisik dan mental, termasuk hukuman fisik dan pelecehan seksual dalam keluarga, sekolah dan institusi perawatan; ini harus disertai dengan kemediaan dan peningkatan dari pelayanan rehabillitasi, pelatihan untuk bekerja professional dengan anak-anak dan kampanye kesadaran masyarakat.

9. Meninjau kebijakan dan praktek yang berkaitan terhadap penanganan anak-anak cacat dan mempromosikan rehabilitasi berbasis masyarakat dan program pendidikan inklusif.

10. Meninjau dan mengevaluasi administrasi peradilan anak, khususnya kesesuaian antara undang-undang dan pelaksanaan KHA di lapangan, serta sesuai dengan standar internasional yang relefan.

\section{Status Hak Perlindungan}

Deklarasi presiden dari dekade kedua untuk perlindungan dan kesejahteraan anak (Tahun 2000 sampai 2010) menempatkan anak-anak digaris depan agenda pembangunan nasional. Pemerintah telah menempatkan rencana aksi nasional untuk mempromosikan perlindungan anak, termasuk rencana aksi nasional tentang kekerasan terhadap anak dan strategi nasional terhadap pekerja anak. Badan koordinasi utama yaitu dewan nasional anak dan keibuan telah menerapkan berbagai program untuk anak-anak beresiko, seperti pusat pengaduan untuk anak. ${ }^{22}$

Meskipun komitmen pemerintah telah berkomitmen untuk melindungi anak-anak, akan tetapi masih banyak anak-anak di Mesir yang mengalami kekerasan, pelecehan dan eksploitasi. Komite hak anak telah menyatakan keprihatinannya pada insiden penganiayaan anak-anak di dalam sekolah dan keluarga, meskipun sudah ada larangan untuk hal ini. tercatat bahwa kekerasan dalam rumah tangga adalah masalah yang belum bisa teratasi di Negara ini. ${ }^{23}$

\footnotetext{
22 The Situation of Children and Woman in Egypt, UNICEF, http:wwwunicef.org/Egypt/overview.html

${ }_{23}$ Yara Abdul Hamid, Child Rights Situation Analiesis For Middle East and North Africa Region, h. 35.
} 
UNICEF juga melaporkan bahwa meskipun sudah ada program pemerintah mengenai anak-anak bermasalah, pelecehan dan kekerasan dirumah sekolah dan jalanan masih sering terjadi. ${ }^{24}$ Koalisi LSM perlidungan hak anak menyatakan bahwa anak perempuan lebih rentan terhadap kekerasan dan perlakuan buruk dari pada anak laki-laki, terutama ketika mereka mencapai usia 17 tahun.

Saat ini mekanisme perlindungan anak yang komperhensif tidak eksis di banyak komunitas atau tidak cukup mengatasi kebutuhan anak-anak tanpa pengasuhan yang memadai, terutama anak-anak yang hidup di jalanan, diperkirakan saat ini berjumlah antara 83.000 hingga 2 juta. Anak-anak yang hidup di jalanan sangat rentan terhadap eksploitasi seksual komersial dan kekerasan, terbukti dengan banyaknya anak-anak yang menderita masalah kesehatan mulai dari tuberculosis dan anemia.25 Lembaga legislatif telah mengamandemen Hukum Anak Mesir tahun 1996 yang kemudian ditandatangani oleh presiden Hosni Mubarak pada tanggal 4 Maret 2008 dan disahkan oleh parlemen Mesir pada bulan Juni 2008. Dibawah undang-undang baru tersebut Komite Perlindungan Anak akan dibentuk untuk memantau anakanak bermasalah dan mencetuskan ide tentang prosedur hukum yang diperlukan untuk melindungi anak-anak. ${ }^{26}$

Di bawah undang-undang baru ini, ibu dari anak yang lahir di luar nikah diberikan hak untuk mendapatkan akta kelahiran, yang diperlukan di Mesir untuk memiliki akses ke layanan kesehatan dan pendidikan, dan usia minimum pernikahan gadis telah meningkat menjadi 18 tahun. ${ }^{27}$ Undang-undang ini juga telah memperketat hukuman bagi siapapun yang ditemukan memiliki anak yang dipaksa untuk bekerja dan usianya dibawah 14 tahun, maka ia akan dihukum penjara antara tiga sampai enam bulan. Dengan melonjakknya harga pangan di Mesir yang mencerminkan tren harga pangan global, insiden anak yang bekerja akan meningkat karena semakin banyak keluarga miskin yang berjuang untuk mengatasi hal ini. ${ }^{28}$

\section{Status Hak Pendidikan}

Pasal 18 dari Undang-Undang Tahun 1971 telah mendefinisikan pendidikan sebagai hak yang dijamin oleh Negara dan Undang-Undang Tahun 1981 menetapkan bahwa pendidikan harus bebas dari biaya, reformasi hukum selanjutnya pada tahun 1989 ditetapkan bahwa semua anak berhak mengikuti

\footnotetext{
${ }^{24}$ Draft Country Programme Document: EGYPT, UNICEF, 2006.

${ }^{25}$ Experiences With Street Child in Egypt, Center for Child Right and Protections, Cairo, 1995.

26 "Female Genital Mutilation: Issues and Impact", Child Protection, UNICEF, dilihat dari http://www.unicef.org/egypt/protection_148.html.

27 “The ECRC, The Egyptian Centre for Rights of the Child, 6 April 2008.

${ }^{28}$ Child Workers A Growing Problem As Food Prices Rise" Herald Tribune, 4 May 2008.
} 
pendidikan dasar selama sembilan tahun. Pemerintah semakin memprioritaskan pendidikan, terbukti pada tahun 2004 sampai dengan 2007 anggaran untuk pendidikan dasar meningkat empat kali lipat, kementerian strategi pendidikan memiliki tiga tujuan utama, yaitu akses, kualitas dan peningkatan sistem kelembagaan. ${ }^{29}$ Indikator pendidikan telah meningkat selama beberapa dekade terakhir, hal ini terbukti dengan besarnya angka partisipasi murni yaitu $96 \%$ untuk anak laki-laki dan 91\% untuk anak perempuan, dan untuk sekolah menengah memiliki angka partisipasi murni sebesar 85\% untuk laki-laki 79\% untuk perempuan. ${ }^{30}$ Namun sistem pendidikan masih terus menghadapi masalah yang serius dengan dampak buruk pada anak-anak miskin dan rentan. Human Right Watch melaporkan bahwa dalam prakteknya, orang tua dan anakanak dari sekolah umum harus membayar biaya pendaftaran dan asuransi kesehatan, membeli seragam dan perlengkapan sekolah, belum lagi ditekan oleh guru untuk membayar biaya les privat agar anak-anak mereka lulus dalam ujian sekolah. Secara khusus, daerah pedesaan di Mesir merupakan daerah tertinggal dari angka indicator pendidikan Nasional, dan diperkirakan pada tahun 1999/2000 sekitar 23\% proporsi anak-anak miskin keluar dari sekolah nasional. ${ }^{31}$

Hambatan lain yang menghalangi anak-anak untuk mengakses pendidikan yang baik adalah: ${ }^{32}$

1. Sebuah keputusan presiden tahun 2001 hanya mengizinkan anak-anak dari Negara Sudan sebagai pengungsi yang resmi diakui oleh Negara untuk menerima pendidikan dasar dari Negara Mesir. Tetapi, anak-anak ini tetap mengalami kesulitan mengakses pendidikan dikarenakan permasalahan dokumentasi yang tidak dimiliki oleh keluarga pengungsi.

2. Pemerintah Mesir mengumumkan sebuah peraturan menteri tahun 1971 yang melarang hukuman di sekolah, tetapi kekerasan bagi anak perempuan dan laki-laki tetap merajalela.

3. Pelayanan, termasuk pelayanan pendidikan, hanya tersedia 5 persen untuk anak penyandang cacat yang didata berdasarkan kota dan umumnya tidak gratis, yang membuat mayoritas penyandang cacat dari keluarga miskin pedesaan dan perkotaan.

4. Komite hak anak telah menyatakan keprihatinan bahwa sikap diskriminatif terhadap pendidikan anak perempuan, terutama di daearah

29 "Country Profile prepared for the Education for All Global Monitoring Report 2008", Aisha Sabri, Education for all by 2005, UNESCO, 2007.

302000-2006 "Egata "Etatistics", http://www.unicef.org/infobycountry/egypt statistics.html.

31 "UN Common Country Assessment 2005: Embracing the spirit of the millennium declaration", United Nations, Egypt, 2005.

32 Yara Abdul Hamid, Child Rights Situation Analiesis For Middle East and North Africa Region, h. 36. 
pedesaan, mengakibatkan pendaftaran untuk bersekolah menjadi rendah dan tingginya angka putus sekolah, sehingga akibatnya terjadilah pernikahan dini atau paksa. UNICEF memperkirakan bahwa 17\% anakanak terlibat dalam pernikahan dini pada tahun 1987 dan 2006.

5. Komite perlindungan hak buruh migran dan keluarga menyampaikan penyesalan bahwa anak buruh migrant yang lahir di Mesir, tidak diberikan akta kelahiran oleh catatan sipil Mesir, sebagian besar anakanak pekerja migran yang memiliki dokumen ataupun tidak memiliki dokumen tidak mendapatkan akses untuk mengenyam pendidikan baik di seolah swasta maupun negeri.

\section{4) Qatar}

A. Masyarakat dan Budaya yang Berhubungan dengan Anak-Anak

Pengaruh tradisi suku baduy di Qatar masih sangat kuat. Komite hak anak telah menyatakan keprihatinannya terhadap praktek-praktek tradisional yang digunakan dalam membesarkan anak-anak di lingkungan keluarga dan sekolah, yang mungkin tidak menghormati pendapat anak dan dapat mengurangi kesempatan mereka untuk mengekspresikan diri. ${ }^{33}$

\section{Status Hak Anak}

Konvensi PBB tentang hak anak KHA ditandatangani oleh Qatar pada tanggal 8 Desember 1992, dan mulai berlaku pada tanggal 3 Mei 1995. Setelah meratifikasi KHA, Qatar memasuki reservasi umum oleh Negara Qatar tentang ketentuan yang sesuai dengan hukum Islam.

Pada tanggal 29 Oktober 1999 Qatar memberikan laporan terkait implementasi KHA, dari laporan tersebut KHA mengeluarkan rekomendasi dan pengamatan sebagai berikut: ${ }^{34}$

1. Anak-anak di bawah umur 18 tahun bisa diadili atas kejahatan sebagai orang dewasa dan mereka dapat dikenakan hukuman yang sama, termasuk hukuman mati, penjara seumur hidup dan sangsi peradilan seperti cambuk.

2. Usia minimum untuk menikah dan bekerja dalam hukum Qatar perlu ditinjau agar sesuai dengan ketentuan KHA.

33 "Draft Programme Draft Programme of co-operation between the Government of Qatar and UNICEF Gulf Area Office, 2007-2009". UNICEF.

34 Yara Abdul Hamid, Child Rights Situation Analiesis For Middle East and North Africa Region, h. 97. 
3. Diskriminasi terhadap perempuan dan anak-anak diluar nikah tetap mendapatkan hak yang sama sebagai orang biasa baik dalam hal kewarisan, hak asuh dan perwalian.

4. Asas-asas dalam KHA mengenai non diskriminasi dan menghormati pandangan anak tidak cukup dimasukkan kedalam kerangka hukum dan kelembagaan saja.

\section{Status Hak Perlindungan}

Dalam tinjauan laporan awal Qatar pada pelaksanaan protokol opsional KHA tentang penjualan anak, prostitusi anak dan pornografi anak pada tahun 2006, komite hak anak menyambut penerapan konstitusi baru yang memperkuat perlindungan hak asasi semua warganegara termasuk anak-anak menyediakan perawatan bagi pemuda-pemudi dan melindungi mereka dari eksploitasi dan penelantaran.

Sebuah komite nasional yang terdiri dari Dewan Tinggi Urusan Keluarga, dibentuk pada tahun 2006 untuk menyusun Undang-Undang tentang hak anak yang sesuai dengan KHA. Negara Qatar meningkatkan perhatian untuk mengembangkan kerangka kerja legislasi demi melindungi anak dari kekerasan, penelantaran dan pelecehan.

Program untuk perlindungan anak diwujudkan dengan mendirikan rumah lindung dan perawatan manusia yang bertugas memberikan bantuan sosial, hukum psikologis dan medis untuk korban pelecehan. Selain itu bertugas untuk bekerjasama dengan polisi, pengadilan, direksi hak asasi manusia di departemen dalam negeri dan yayasan perlindungan perempuan dan anak Qatar. Yang membentuk tiga pusat layanan sebagai tempat konseling. ${ }^{35}$ Pada tahun 2006 yayasan ini menangani 190 kasus yang melibatkan anak-anak antara lain kasus penganiayaan, pelecehan psikologis dan penelantaran. Diantara kasus-kasus tersebut hanya ada dua kasus pelecehan seksual. Sebagian besar kasus-kasus anak tersebut terjadi di lingkungan sekolah, rumah sakit dan lingkungan masyarakat. ${ }^{36}$ Selain itu Dewan Tinggi Urusan Keluarga telah menyiapkan pusat kebudayaan ibu dan anak yatim untuk memberikan pelayanan kepada anak-anak yang membutuhkan.

Komite Hak anak telah menyatakan apresiasi terhadap perlindungan hak-hak anak yang sedang dilaksanakan oleh Qatar, akan tetapi tetap merasa prihatin tentang isu-isu kekerasan dan eksploitasi anak di Negara tersebut.

35 "Report of the Special Rapporteur on Trafficking in persons, especially women and children". Sigma Huda, Mission to Bahrain, Oman and Qatar, Human Rights Council, A/HRC/4/23/Add.2, 25 April 2007.

36 "Qatar-2006 Country Reports on Human Rights Practies", US State Department, 6 Maret 2007. 
Kemudian KHA merekomendasikan agar Qatar mendirikan pusat pelayanan 24 jam gratis untuk anak-anak korban kekerasan dan pelecehan dan mengambil langkah-langkah khusus untuk mengatasai kelompok mayoritas anak seperti anak-anak pekerja migrant atau anak-anak yang diperdagangkan dan juga merekomendasikan untuk sumber daya manusia dan sumber daya keuangan yang terbaik untuk melaksanakan perlindungan hak-hak anak.

Pada tahun 2003 pemerintah juga mengembangkan rencana nasional untuk mengatasi perdagangan manusia dan menunjuk seorang coordinator nasional untuk masalah perdagangan ini yang bertugas melaporkan langsung kepada dewan tertinggi urusan keluarga dan bekerjasama dengan sejumlah lembaga pemerintah lainnya seperti kantor kejaksaan, departemen kehakiman dan departemen dalam negeri.

Salah satu isu perlindungan hak anak yang paling penting adalah perdagangan anak khususnya yang digunakan sebagai joki untuk anak unta. Untuk memperbaiki situasi ini Qatar mengesahkan Undang-Undang No 22 tahun 2005 tentang pelarangan ketenagakerjaan, pelatihan dan partisipasi anak dalam balapan unta. Pelanggaran hukum ini akan dikenakan sangsi tiga sampai sepuluh tahun penjara, dan denda sebanyak 50.000 hingga 200.000 real. Selain itu kantor hak asasi manusia di kementerian luar negeri diperintahkan untuk memerangi perdagangan manusia bekerjasama dengan dewan tertinggi urusan keluarga yang telah dibentuk untuk meningkatkan kesadaran masyarakat terhadap perdagangan manusia.

Qatar juga berinvestasi dalam pengembangan joki robot untuk mengurangi permintaan jumlah joki anak. Namun ada laporan bahwa meskipun ada pemulangan sejumlah besar anak-anak tetapi tetap saja anak-anak itu dipekerjakan sebagai buruh tani yang hidup dalam kondisi sulit.

Undang-undang melarang kerja paksa dan mewajibkan belajar untuk anak-anak. Qatar telah meratifikasi konvensi buruh internasional tentang bentuk-bentuk pekerjaan terburuk untuk anak, tetapi belum meratifikasi konvensi usia minimum bekerja. Anak-anak antara usia 15-18 tahun memiliki hak untuk bekerja dengan izin orang tua. Beberapa anak-anak bekerja di bisnis milik keluarganya, maka pengusaha perlu meminta izin dari departemen pendidikan untuk mepekerjakan anak-anak dibawah umur. Anak dibawah umur tidak diperbolehkan untuk bekerja lebih dari 6 jam sehari atau 36 jam perminggu. Ketenagakerjaan anak dibawah umur dilarang dalam pekerjaan berbahaya atau tidak sehat, meskipun sudah ada undang-undang namun ketenagakerjaan anak masih merupakan masalah, terutama bagi anak-anak asing. ${ }^{37}$

37 "Making Children's Rights Work: Country Profile on Qatar", International Bureau for Children Rights, 2007. 


\section{Status Hak Pendidikan}

Pasal 8 dari konstitusi menetapkan bahwa pendidikan merupakan faktor dasar dalam kemajuan dan kesejahteraan masyarakat dan merupakan hak setiap warga Negara. Negara harus berusaha untuk mewujudkan pelaksanaan pendidikan umum gratis pada semua tingkatan. Pendidikan gratis di Qatar diperuntukkan untuk anak-anak sampai usia 15 tahun. Statistik menunjukkan bahwa 30\% dari anak-anak mendaftarkan diri ke pendidikan usia dini dalam jangka tiga sampai lima tahun. Dalam tingkat pendidikan dasar, total pendaftaran rata-rata untuk anak laki-laki dan perempuan sebesar $96 \%$. Dan rata-rata total pendaftaran pada sekolah tingkat menengan sebesar $91 \%$ untuk anak laki-laki dan $89 \%$ untuk anak perempuan. ${ }^{38}$

Komisi Hak Anak telah menyatakan keprihatinannya mengenai fokus sektor pendidikan yang lebih terfokus pada hafalan dibandingkan dengan mengembangkan kemampuan analisis dan partisipasi anak. Dewan Mahkamah Pendidikan dibuat pada tahun 2002 yang ditugaskan untuk merombak total sistem sekolah tradisional Qatar. ${ }^{39}$

\section{Kesimpulan}

Hukum perlindungan anak dari empat Negara tersebut sama-sama menggunakan Konvensi Hak Anak sebagai dasar dari hukum perlindungan anak di Negara tersebut. perbedaannya hanya dalam teknis pelaksanaan dalam penegakan Hukum Perlindungan Anak saja.

\section{Daftar Pustaka}

\section{Buku:}

Aji, Ahmad Mukri. Kontekstualisasi Ijtihad Dalam Diskursus Pemikiran Hukum Islam di Indonesia, Bogor: Pustaka Pena Ilahi, 2010.

Aji, Ahmad Mukri. Urgensi Maslahat Mursalah Dalam Dialektika Pemikiran Hukum Islam, Bogor: Pustaka Pena Ilahi, 2012.

Awal, Noor Aziah Mohd. Child Act 2001 How Far Does it Conform to the UNCRC?, (Kuala Lumpur: Penerbit Universiti Malaya, 2002).

Hamid, Yara Abdul. Child Rights Situation Analiesis For Middle East and North Africa Region, (Swedia: Menaregional Office, 2008).

\footnotetext{
Qatar Statistik Data 2000-2006,

UNICEF, http://www.unicef.org/infobycountry/qatar_statistic.html

${ }^{39}$ US State Departement, Qatar - 2006 - Country Reports on Human Right Practices".
} 
Hua, Chew Li. Criminal Prosedur Under Part X of the Child Act 2001, (Kuala Lumpur: University Malaya, 2003).

Jamaluddin, Siti Zahara. Akta Kanak-Kanak: Implikasinya Terhadap Ibu Bapa, Agensi Kerajaan, Badan Kehakiman dan Media, (Kuala Lumpur: University Malaya, 2002).

Joni, Muhammad; dan Taramas, Zulchaina Z. Aspek Hukum Perlindungan Anak dalam Perspektif Hak Anak, (Bandung: PT. Citra Aditya Bakti, 1999).

Lembaga Penyelidikan Undang-Undang, Akta Kanak-Kanak 2001 (Akta 611), (Kuala Lumpur: International Law Book Services, 2002).

Maggalatung, A Salman. "Hubungan Antara Fakta Norma, Moral, Dan Doktrin Hukum Dalam Pertimbangan Putusan Hakim," dalam Jurnal Cita Hukum, Vol. 2, No. 2 (2014).

Maggalatung, A Salman; Yunus, Nur Rohim. Pokok-Pokok Teori Ilmu Negara, Cet1, Bandung: Fajar Media, 2013.

Makarao, Muhammad Taufik. dkk, Hukum Perlindungan Anak dan Penghapusan Kekerasan Dalam Rumah Tangga, Jakarta: Rineka Cipta, 2013.

Takir, Zulazhar. Meninjau Isu Penderaan Kanak-Kanak dari Perspektif Akta KanakKanak 2001, Kuala Lumpur: Penerbit University Malaya, 2002.

Talib, Norchaya, Siri Undang-Undang dari Akta Kanak-Kanak 2001, Kuala Lumpur: University Malaya, 2002.

Yunus, Nur Rohim. Restorasi Budaya Hukum Masyarakat Indonesia, Bogor: Jurisprudence Press, 2012.

\section{Website:}

Child Right Information Network. Convention on the Rights of the Child. Diakses pada tanggal 26 November 2008.

Child Right Information Network (CRIN), http;//www.crin.org/law/instrument.asp?instID=1157

The Situation of Children and Woman in Egypt, UNICEF, http:www.unicef.org/Egypt/overview.html

Draft Country Programme Document: EGYPT, UNICEF, 2006.

Experiences With Street Child in Egypt, Center for Child Right and Protections, Cairo, 1995.

"Female Genital Mutilation: Issues and Impact", Child Protection, UNICEF, dilihat dari http://www.unicef.org/egypt/protection 148.html. 
"The ECRC, The Egyptian Centre for Rights of the Child, 6 April 2008.

Child Workers A Growing Problem As Food Prices Rise" Herald Tribune, 4 May 2008.

"Country Profile prepared for the Education for All Global Monitoring Report 2008", Aisha Sabri, Education for all by 2005, UNESCO, 2007.

“Draft Programme Draft Programme of co-operation between the Government of Qatar and UNICEF Gulf Area Office, 2007-2009". UNICEF.

"Report of the Special Rapporteur on Trafficking in persons, especially women and children". Sigma Huda, Mission to Bahrain, Oman and Qatar, Human Rights Council, A/HRC/4/23/Add.2, 25 April 2007.

"Qatar-2006 Country Reports on Human Rights Practies", US State Department, 6 Maret 2007.

"Making Children's Rights Work: Country Profile on Qatar", International Bureau for Children Rights, 2007.

Qatar Statistik Data 2000-2006, UNICEF, http://www.unicef.org/infobycountry/qatar_statistic.html

US State Departement, Qatar - 2006 - Country Reports on Human Right Practices". 


\title{
Kasus Pelecehan Seksual Dalam Transportasi Umum Menurut Putusan Pengadilan Negeri Jakarta Pusat" (Sexual Harassment CasesIn public transportation According to the Decision of the Central Jakarta District Court)
}

\author{
Iqbal Ramdhani ${ }^{1}$ \\ Universitas Islam Negeri Syarif Hidayatullah Jakarta \\ do) $\underline{10.15408 / \operatorname{sjsbs.v4i1.7871}}$
}

\begin{abstract}
.
The act of sexual harassment is not strange anymore and it has happened everywhere, in offices, supermarkets, tourist attractions, malls, and public transportation. Ironically, victims of sexual abuse are not only normal women, but also women with disabilities. Cases of sexual abuse in this case have been tried in the Central Jakarta District Court. Decision of the Central Jakarta District Court No. 753 / PID.B / 2014 / PN.JKT.PST. The Panel of Judges stated and determined that the defendant had been proven and convincingly guilty of committing a criminal offense set out in article 290 of the first Criminal Code in conjunction with article 55 paragraph (1) of the first Criminal Code. Then the judge sentenced him to 1 (one) year and 6 (six) months imprisonment.
\end{abstract}

Keywords: Sexual Harassment, Public Transportation, Jakarta Courts

\begin{abstract}
Abstrak:
Tindakan pelecehan seksual sudah tidak aneh lagi dan sudah banyak terjadi dimanamana, di kantor, supermarket, tempat wisata, mall, dan angkutan umum. Ironisnya korban pelecehan seksual itu tidak hanya perempuan normal, akan tetapi juga perempuan penyandang cacat. Kasus pelecehan seksual dalam hal ini sudah pernah diadili di Pengadilan Negeri Jakarta Pusat. Putusan Pengadilan Negeri Jakarta Pusat No. 753/PID.B/2014/PN.JKT.PST. Majelis Hakim menyatakan dan menetapkan bahwa terdakwa telah terbukti dan meyakinkan bersalah melakukan tindak pidana yang diatur dalam pasal 290 ke-1 KUHP jo pasal 55 ayat (1) ke-1 KUHP. Maka hakim menjatuhkan hukuman pidana penjara 1 (satu) tahun dan 6 (enam) bulan.
\end{abstract}

Kata Kunci: Pelecehan Seksual, Transportasi Umum, Pengadilan Jakarta

* Diterima tanggal naskah diterima: 15 Desember 2017, direvisi: 24 Maret 2017, disetujui untuk terbit: 21 April 2017.

1 Penulis adalah Peneliti pada Fakultas Syariah dan Hukum, Universitas Islam Negeri (UIN) Syarif Hidayatullah Jakarta. Jl. Ir. H. Juanda No. 95 Ciputat Tangsel. E-mail: iqbalramdhani@uinjkt.ac.id. 


\section{Pendahuluan}

Negara Indonesia sedang mengalami hilangnya rasa aman, dipicu oleh maraknya berbagai aksi kriminal. Tindak kekerasan telah menjadi fenomena dalam kehidupan masyarakat di Indonesia. Kekerasan terjadi bukan saja dalam area publik, namun marak terjadi juga dalam area domestik yang melahirkan kekerasan dalam rumah tangga. ${ }^{2}$

Salah satu pihak yang paling sering merasakan kurang aman adalah kaum perempuan, dimana kaum perempuan sering mendapatkan kejahatan seksual seperti pelecehan seksual, sampai pemerkosaan. ${ }^{3}$ Secara umum definisi pelecehan seksual adalah setiap tindakan perilaku/gerak-gerik seksual yang tidak dikehendaki dalam bentuk verbal (kata-kata) atau tulisan, fisik, tidak verbal, dan visual untuk kepentingan seksual, memiliki muatan seksual sehingga menyebabkan kemarahan, perasaan terhina, malu, tidak nyaman dan tidak aman bagi orang lain. Adapun kejahatan seksual itu bisa dilakukan siapa saja baik itu laki-laki, perempuan, anak-anak, ataupun orang tua. Pelecehan seksual merupakan bentuk diskriminasi seks dan juga merupakan pelanggaran hak asasi manusia. Kejahatan seksual semakin lama semakin berkembang karena tingkat kesadaran dari perempuan terhadap pakaian yang dikenakan tidak mencerminkan kesopanan.

Tindakan pelecehan seksual sudah tidak aneh lagi dan sudah banyak terjadi dimana-mana di kantor, supermarket, tempat wisata, mall, dan angkutan umum. Terjadinya pelecehan seksual bisa dipicu oleh cara berpakaian seseorang, apalagi sekarang ini pergaulan anak muda sudah semakin bebas dalam cara berpakaian dan bergaul, maka dari itu tidak aneh sekarang ini banyak perempuan yang berpakaian senonoh. Ironisnya korban pelecehan seksual itu tidak hanya perempuan normal akan tetapi sering juga perempuan penyandang cacat mendapatkan perlakuan pelecehan itu. Sikap seksual yang negatif, selama berabad-abad, terus mempengaruhi massa rakyat yang terlalu mudah percaya, dalam bentuk penolakan yang teramat keras terhadap seks, moral seksual merupakan bagian yang integral dari etika perilaku yang dapat diterapkan pada manusia, yang termasuk dalam etika seksual adalah sebagian dari berbagai norma sosial, pola perilaku, dan kebiasaan pribadi yang berhubungan langsung dengan naluri seksual. ${ }^{4}$ Menurut catatan Komisi Nasional Anti Kekerasan

${ }^{2}$ La Jamaa. "Perlindungan Korban Kekerasan Dalam Rumah Tangga Dalam Hukum Pidana Indonesia” JURNAL CITA HUKUM [Online], Volume 2 Number 2 (2 Desember 2014), h. 250

${ }^{3}$ Chairil A Adjis dan Dudi Akasyah, Kriminologi Syariah, (Jakarta: Rmbooks, 2007), h. 222.

${ }^{4}$ Murtadha Muthahhari, Etika Seksual Dalam Islam, (Jakarta: PT Lentera Basritama 1993), h. 19. 
Terhadap Perempuan pada tahun 2012 sampai dengan tahun 2013 kekn erasan terhadap perempumencapai 216.156 kasus. $^{5}$

Kejahatan terhadap perempuan sering mengalami perlakuan tidak adil dan pelanggaran hak-haknya. Perkosaan, pelecehan seksual dan kekerasan lain yang dimotivasi nafsu seks yang menjadi bahaya nyata yang mengancam pihak perempuan, hingga kini kejahatan kesusilaan terhadap perempuan terjadi. Pelecehan seksual dan cabul merupakan isu yang juga sensitif. Disini pentingnya Hak Asasi Manusia (HAM) bagi setiap individu, sehingga eksistensinya harus senantiasa diakui, dihargai, dan dilindungii diantaranya melalui berbagai produk perundang-undangan. Adanya pengakuan terhadap eksistensinya HAM tentu membawa konsekwensi pada perlunya diupayakan perlindungan terhadap hak-hak tersebut dari kemungkinan munculnya tindakan-tindakan yang merugikan manusia itu sendiri, baik dilakukan oleh manusia lainnya maupun oleh pemerintah. Perlindungan hukum pada korban kejahatan secara memadai sudah menjadi isu global, korban kejahatan yang pada dasarnya merupakan pihak yang paling menderita dalam suatu tindak pidana, justru tidak memperoleh perlindungan sebanyak yang diberikan oleh undang-undang kepada pelaku kejahatan. Akibatnya pada saat pelaku kejahatan dijatuhi sanksi pidana oleh pengadilan, kondisi korban kejahatan seperti tidak dipedulikan lagi. Padahal masalah keadilan dan penghormatan HAM tidak hanya terhadap pelaku saja tetapi juga harus dapat menjangkau korban kejahatan itu. ${ }^{6}$

Tindakan pelecehan seksual yang terjadi merupakan suatu masalah yang memerlukan perhatian khusus pemerintah karena hal ini berkaitan dengan moralitas para generasi bangsa. Dalam hal ini pengadilan yang merupakan instansi atau lembaga yang menangani masalah hukum perlu memberikan sanksi pada seseorang yang melakukan tindak pidana terutama pelaku kejahatan seksual untuk itu pengadilan perlu memberikan sanksi terhadap pelaku pelecehan seksual dengan seadil-adilnya.

Sedangkan dalam Islam terhadap perilaku pelecehan seksual ini belum diatur secara jelas, karena pembahasan tentang perilaku pelecehan seksual belum ada dalam Alquran maupun Hadist, jadi ketentuan hukum tentang pelecehan seksual ini masih menjadi ijtihad para ulama. Hukuman terhadap pelaku pelecehan seksual bisa berbentuk $t a^{\prime} z i r$, adapun bentuk hukumannya bisa berupa hukuman, mati, diasingkan, cambuk, denda dan lain-lain, adapun hukuman ta'zir yang dilakukan bagi pelaku pelecehan seksual harus sesuai dengan apa yang dilakukan kepada pelaku demi keamanan.

${ }^{5}$ Muhammad Ishar Helmi. "PENGADILAN KHUSUS KDRT: “Implementasi Gagasan Sistem Peradilan Pidana Terpadu Penanganan Kasus-Kasus Kekerasan Terhadap Perempuan (SPPT-PKKTP)" JURNAL CITA HUKUM [Online], Volume 2 Number 2 (2 Desember 2014), h. 318

${ }^{6}$ Romi Asmara dan Laila M, "Rasyid, Perlindungan Hukum Terhadap Anak Perempuan Korban Kejahatan Kesusilaan Di Kota Lhokseumawe”, dalam Jurnal Ilmu Hukum, No 60, Lhokseumawe-Aceh. h. 203. 
Dalam Alquran tidak ada yang menjelaskan tentang pelecehan seksual yang ada dalam kitab suci Alquran itu hanya menjelaskan tentang zina. Dalam hukum Islam tidak dibenarkan dalam berpacaran sampai memegang tangan perempuan yang belum mahram, dan dalam agama Islam juga ada larangan terhadap memandang lawan jenisnya terlalu lama ditakutkan akan menimbulkan syahwat dan akan membawa kearah zina, larangan terhadap mendekati zina terdapat dalam firman Allah surat Al-Isra' ayat 32 yang artinya: "Dan janganlah kamu mendekati zina; sesungguhnya zina itu adalah suatu perbuatan yang keji. Dan suatu jalan yang buruk." (QS. Al-Israa': 32).

Ayat di atas dengan tegas menjelaskan bahwa larangan terhadap mendekati zina. Dimana bermakna sangat mendalam, yaitu apa saja yang mendekati zina adalah haram terlebih lagi berzinanya sudah sangat jelas diharamkan.Adapun mendekati zina dalam prakteknya ada beberapa pendekatan, seperti khalwat, ikhtilat, mengumbar aurat, pandangan mata yang liar dan pikiran atau hati yang kotor. Tidak hanya melarang mendekati zina tapi Islam juga memerintahkan untuk menjaga pandangan terhadap siapa saja kecuali dengan suami mereka. Disamping itu, Allah mengajarkan agar hubungan seksual itu dilakukan dengan cara yang halal, baik, sehat dan bermartabat. Meskipun demikian banyak muda-mudi yang tidak memahami keluhuran ajaran Allah ini. Saat ini tidak sedikit manusia terjerumus kepada budaya pergaulan bebas.

Hukum Islam belum menjelaskan sanksi hukum terhadap pelaku pelecehan seksual apakah takzir, had, seperti hukuman pada perbuatan zina. Karena masih jadi perdebatan para ulama. Bagi pelaku pelecehan seksual bisa dikenakan hukuman takzir bentuk hukuman ini diserahkan kepada hakim yang berhak memutuskan suatu perkara. Di Indonesia berkaitan dengan perkara kejahatan asusila diputuskan berdasarkan ketentuan-ketentuan dalam KUHP. Walaupun sanksi pidana yang terdapat dalam KUHP ini dinilai belum memadai, korban pelecehan seksual pun masih belum mendapatkan keadilan terhadap hukum di Indonesia yang menganut hukum belanda dan belum adanya ketegasan terhadap perlindungan bagi korban pelecehan seksual, mungkin dari itu semakin maraknya kasus pelecehan seksual di Indonesia karena belum diaturnya dalam KUHP.

\section{Pornografi Penyebab Kejahatan Seksual}

Kasus tindak pidana kejahatan seksual belakangan ini marak terjadi, pelaku kejahatan seksual tidak hanya dilakukan oleh orang dewasa, namun juga anak-anak dibawah umur. Korban kekerasan seksual tidak hanya wanita dewasa, melainkan anak yang masih balita juga sering menjadi korban kekerasan 
seksual. Pelaku tindak pidana kejahatan seksual tersebut selalu menyatakan bahwa perbuatannya itu merupakan dampak negatif dari konsumsi pornografi. ${ }^{7}$

Penyebab utama masyarakat dapat terpengaruh pornografi adalah dengan banyaknya konten-konten porno yang mudah diakses oleh seluruh masyarakat melalui internet, media cetak, hingga tayangan media televisi yang menayangkan tayangan yang menggambarkan unsur porno. Beberapa faktor diatas dapat menyebabkan merebaknya kejahatan kesusilaan, terutama perkosaan, pelecehan seksual/pencabulan.

Pornografi memberikan dampak yang negatif pada orang yang mengkonsumsinya secara berlebihan dan tanpa arahan, terutama berpengaruh pada mental dan pola pikir seseorang. Dampak buruk dari pornografi adalah:

a. Memberikan fatamorgana negatif dalam imajinasi pengkonsumsi pornografi, yang mengakibatkan mereka tersiksa dari sudut mental;

b. Memicu tindakan pemuasan seksual dengan diri sendiri, yaitu masturbasi atau onani;

c. Mendorong pemuasan seksual pada sosok yang tak berdaya (memperkosa, mencabuli), lawan jenis dan bahkan sejenis yang di dalamnya termasuk anak-anak yang ada dalam posisi lebih lemah;

d. Memicu hubungan seksual yang ekstrim, seperti hubungan seksual dengan keluarga sendiri, orang yang masih sangat kecil atau orang yang lebih tua;

e. Mengganggu proses berpikir kreatif;

f. Mendorong rasa ingin tahu mengenai hal-hal yang berbau pornografi

g. Menimbulkan sikap agresif yang tidak terkontrol. ${ }^{8}$

Penjelasan di atas, sudah jelas dampak dari mengkonsumsi konten pornografi sangat berbahaya bukan hanya untuk kesehatan tetapi dari kebanyakan konten pornografi ini bisa menimbulkan penyimpangan seksual sehingga berakibat kejahatan seksual akan timbul dengan sendirinya. Kejahatan seksual dalam persfektif masyarakat bisa menimbulkan reaksi dan sikap yang semuanya bergantung pada derajat atau kualitas penyimpangan lazimnya berbentuk seperti perzinahan, homoseksual, kumpul kebo, lesbian, pelacuran, pencabulan dan perkosaan. ${ }^{9}$ Kejahatan seksual menimbulkan kekerasan tetapi kejahatan seksual tersebut ada yang tidak berbentuk kekerasan, yaitu kejahatan seksual yang dilakukan dengan suka sama suka misalnya berhubungan dengan

7 Rusman widodo, Darurat Kejahatan Seksual Terhadap Anak, (Suar Komnas Ham No.1 2014), h.13

https://alwardah.wordpress.com/pornografi-menyebabkan-kecanduan-seksual-2/. Diakses tanggal 11 Februari 2016, pukul 1:07.

${ }^{9}$ Kartini Kartono, Patologi Sosial, Jilid I Edisi Baru (Jakarta: Rajawali Press, 1983), h.51 
pacar dan kejahatan melalui transaksi seperti pelacuran. Mengenai kekerasan yang terkait dengan hubungan seksual tidak selalu dapat dikatakan sebagai kejahatan bilamana ketentuan perundang-undangan (hukum) tidak atau belum mengaturnya. Misalnya pemaksaan hubungan seksual yang dilakukan oleh suami terhadap istri, hal tersebut tidak dapat dikatakan sebagai kejahatan karena tidak ada peraturan yang melarangnya. ${ }^{10}$

Kejahatan seksual menimbulkan banyak akibat negatif, apalagi jika korbannya adalah anak yang masih membutuhkan waktu tumbuh dan berkembang. Tindak kekerasan tersebut pasti akan sangat membekas dan meninggalkan efek yang lama baik secara fisik maupun mental. Adapun dampak dari kejahatan seksual adalah:

- Penderitaan secara psikologis, seperti merasa tidak lagi berharga akibat kehilangan kesucian dimata keluarga, teman, dan masyarakat, penderitaan psikologis lainnya dapat berupa kegelisahan, kehilangan kepercayaan diri, tidak ceria, sering menutup diri, tumbuh rasa benci dan curiga berlebihan terhadap pihak lain hingga pikiran bunuh diri.

- Kemungkinan terjadinya kehamilan. Hal ini dapat berakibat fatal karena anak yang dilahirkan nantinya tidak memiliki kejelasan statusnya baik secara yuridis maupun norma keagamaan.

- Penderitaan fisik, artinya akibat kekerasan seksual akan menimbulkan luka pada diri korban. Luka ini tidak hanya dibagian kelamin yang robek, namun kemungkinan juga adanya organ tubuh lain yang mengalami kekerasan fisik saat kekerasan seksual itu terjadi pada korban.

- Korban yang dihadapkan dengan situasi sulit dapat saja terjerumus dalam dunia yang salah, mulai dari adanya rasa dendam, dia ingin orang lain merasakan apa yang dirasakannya sehingga dia jadi pelaku ataupun korban bisa terjerumus kedunia prostitusi. ${ }^{11}$

Kejahatan ini merupakan bentuk pelanggaran atas kesusilaan yang ada diseluruh dunia, yang juga merupakan salah satu bentuk kejahatan melecehkan dan menodai harkat manusia sehingga patut dikategorikan sebagai jenis kejahatan melawan kemanusiaan dan melanggar Hak Asasi Manusia (HAM). Istilah kesusilaan sendiri tidak ada penjelasaan secara jelas dalam KUHP, namun menurut R. Soesilo kesusilaan adalah; segala perbuatan yang melanggar

\footnotetext{
10 Abdul Wahid dan Muhammad Irfan, Perlindungan Terhadap Korban Kekerasan Seksual Advokasi atas Hak Asasi Perempuan, (Bandung: Reflika Aditama, 2011), h. 25

11 Abdul Wahib dan Muhammad Irfan, Perlindungan Terhadap Korban kekerasan Seksual Advokasi atas Hak Asasi Perempuan (Bandung: Refika Aditama, 2011), h, 82
} 
kesopanan atau perbuatan keji, semuanya itu dalam lingkungan nafsu birahi kelamin, misalnya ciuman, meraba daerah sensitif tubuh manusia. ${ }^{12}$

\section{Bentuk-Bentuk Kejahatan Seksual}

Bentuk-bentuk kejahatan seksual umumnya dilakukan dengan upaya memaksa keinginan salah satu pihak saja untuk merayu, mencolek, memeluk, meremas bagian tubuh, dan segala macam bentuk pelecehan lainnya hingga tujuan utamanya adalah melakukan persetubuhan paksa. Di Indonesia terdapat beberapa Undang-undang yang menyangkut kejahatan seksual, serta ketentuan dalam KUHP yang menyangkut kekerasan seksual dapat dilihat pada BAB XIV tentang kejahatan terhadap kesusilaan dan beberapa Undang-undang lainnya. Dari bentuk-bentuk kejahatan seksual adalah sebagai berikut:

Pertama, Perkosaan. Perkosaan bisa dimaknai sebagai serangan dalam bentuk pemaksaan hubungan seksual, dalam serangan seksual itu ada upaya paksa, kekerasan, tekanan psikologis, penyalahgunaan kekuasaan atau mengambil kesempatan dari lingkungan yang penuh paksaan, dalam perkosaan terdapat unsur pemaksaan terhadap korban membuat pihak wanita merasa dirugikan, maka dalam pasal 285 KUHP menyebutkan "barang siapa dengan kekerasan atau dengan ancaman kekerasan memaksa seseorang bersetubuh dengan laki-laki diluar perkawinan, diancam karena melakukan perkosaan dengan pidana penjara paling lama 12 tahun. Perkosaan selalu identik dengan persetubuhan yang dipaksakan, persetubuhan sendiri menurut rumusan KUHP adalah tindakan memasukan kemaluan laki-laki kedalam kemaluan perempuan yang pada umumnya menimbulkan kehamilan, dengan kata lain bilamana kemaluan itu mengeluarkan air mani di dalam kemaluan perempuan. Oleh karena itu, apabilan dalam peristiwa perkosaan walaupun kemaluan laki-laki telah agak lama masuknya kedalam kemaluan perempuan, air mani laki-laki belum keluar hal itu belum merupakan perkosaan, akan tetapi percobaan perkosaan. Pengertian persetubuhan tersebut masih merupakan pengertian aliran klasik dan menurut teori modern tanpa mengeluarkan air mani pun maka hal terebut sudah dapat dikatakan sebagai persetubuhan sehingga tidak tepat jika hal tersebut masih dianggap sebagai percobaan. ${ }^{13}$

Kedua, Pelecehan Seksual. Pelecehan seksual ini adalah tindakan lewat sentuhan fisik atau nonfisik, yang sengaja atau berulang-ulang, atau hubungan fisik yang bersifat seksual bukan suka sama suka. Namun pelecehan seksual mengacu pada perbuatan yang oleh korbannya dirasa tidak menyenangkan, karena perbuatan tersebut bersifat intimidasi, menghinakan atau tidak

\footnotetext{
12 R. Soesilo, Kitab Undang-undang Hukum Pidana (KUHP) Serta Komentar-komentarnya Lengkap Pasal Demi Pasal, (Bogor: Politea 1988) h. 209

13 R.Soesilo, Kitab Undang-undang Hukum Pidana (KUHP) Serta Komentar-Komentarnya Lengkap Pasal Demi Pasal, (Bogor: Politea, 1988), h. 211
} 
menghargai dengan membuat seorang sebagai obyek pelampiasan seksual. Dalam KUHP tidak ada pasal yang menjelaskan secara langsung pelecehan seksual tetapi kejahatan seksual itu sudah terangkum dalam pasal 289 sampai dengan pasal 296 tentang pencabulan KUHP, karena perbuatan cabul dijelaskan sebagai perbuatan melanggar kesusilaan dan termasuk kedalam kejahatan kelamin, misalnya ciuman, meraba-raba anggota kemaluan, meraba buah dada dan sebagainya..$^{14}$ Dapat disimpulakan bahwa segala perbuatan apabila itu telah dianggap melanggar kesopanan atau kesusilaan bisa dimasukan kedalam perbuatan cabul, dengan demikian pelecehan seksual adalah adanya ketidainginan atau penolakan pada apapun bentuk-bentuk perhatian yang bersifat seksual. Pelecehan seksual ini dapat dijerat dengan pasal percabulan pasal 289 sampai pasal 296 KUHP.।

Ketiga, Eksploitasi Seksual. Eksploitasi seksual tindakan penyalahgunaan kekuasaan yang timpang, atau penyalahgunaan kepercayaan, untuk tujuan kepuasan seksual, atau untuk memperoleh keuntungan. Bentuk yang kerap terjadi adalah menggunakan kemiskinan keluarga perempuan untuk memasukannya kedalam prostitusi atau bisnis pornografi. Terkait kejahatan seksual bentuk ekploitasi ini di atur dalam Undang-Undang No. 44 tahun 2008 tentang Pornografi pasal 1, "Pornografi adalah gambar, sketsa, ilustrasi, foto, tulisan, suara, bunyi, gambar bergerak, animasi, kartun, percakapan, gerak tubuh, atau bentuk pesan lainnya melalui berbagai bentuk media komunikasi dan atau pertunjukan dimuka umum, yang memuat kecabulan atau eksploitasi seksual yang melanggar norma kesusilaan dalam masyarakat. ${ }^{15}$

Keempat, Perdagangan Perempuan Untuk Tujuan Seksual. Perdagangan perempuan untuk tujuan seksual ini meliputi tindakan merekrut, mengangkut, menampung, mengirim, memindahkan atau menerima seseorang dengan paksaan atau rayuan untuk tujuan prostitusi atau eksploitasi seksual. Kejahatan diatas tercantum dalam Undang-Undang No. 21 tahun 2007 pasal 1 angka 1 tentang Pemberantasan tindak pidana perdagangan orang, "Tindakan perekrutan, penampungan, pengangkutan, pengiriman, pemindahan atau penerimaan seseorang dengan ancaman kekerasan, penculikan, penggunaa kekerasan, penyekapan, penipuan, pemalsuan, penyalahgunaan kekuasaan atau posisi rentan, memberi bayaran atau penjeratan utan atau manfaat, sehingga dapat memperoleh persetujuan dari orang yang memegang kendali atas orang lain tersebut, baik yang dilakukan antar negara maupun di dalam negara, demi untuk tujuan mengeksploitasi atau mengakibatkan orang tereksploitasi. ${ }^{16}$

14 http://m.hukumonline.com/klinik/detail/c13746/jerat-hukum-dan-pembuktianpelecehan-seksual. Diakses tanggal 14 oktober 2015, pukul 21:43

15 Pasal 1 Undang-Undang No.44 tahun 2008 tentang Pornografi

16 Pasal 1 angka 1 Undang-Undang No. 21 tahun 2007 tentang Pemberantasan Tindak Pidana Perdagangan Orang. 
Kelima, Perbudakan Seksual. Perbudakan seksual adalah situasi diman pelaku merasa menjadi 'pemilik' atas tubuh korban sehingga berhak untuk melakukan apapun termasuk memperoleh kepuasan seksual melalui pemerkosaan atau cara lain. Dalam kasus perbudakan seksual diatur dalam Undang-Undang No. 21 tahun 2007 tentang tindak pidana perdagangan orang, dalam penjelasan umum dijelaskan definisi perbudakan sebagai berikut. "Perbudakan adalah kondisi seseorang dibawah kepemilikan orang lain. Praktik serupa perbudakan adalah tindakan menempatkan seseorang dalam kekuasaan orang lain sehingga orang tersebut tidak mampu menolak suatu pekerjaan yang secara melawan hukum diperintahkan oleh orang lain itu kepadanya, walaupun orang tersebut tidak menghendakinya."17

Dari bentuk-bentuk kejahatan seksual ini bisa disimpulkan bahwa setiap perbuatan yang berhubungan dengan kelamin bisa disebut dengan tindak pidana karena sudah menghilangkan harkat dan martabat seseorang, maka dari itu perbuatan ini bisa dikenakan sanksi sesuai dengan apa yang mereka perbuat dan harus mempertanggung jawabkan dihadapan hukum.

Adapun faktor yang mendukung terjadinya kejahatan seksual adalah. Faktor yang bersifat internal (dari dalam diri sendiri si korban).

a. Lemah mental: kurang mampu berfikir, membuat penilaian atau pemilihan secara tepat dalam menghadapi persoalan tertentu yang disebabkan kurangnya pendidikan/pembinaan atau kurang sempurnanya daya pikir, dan dihinggapi rasa takut untuk melawan;

b. Lemah fisik: kurang mampu melawan karena keadaan tubuh, kurang mampu melawan karena tidak mempunyai kemampuan/keterampilan bela diri, tidak mempunyai sarana untuk melindungi diri, dan mempunyai kecenderungan tertentu yang dapat menyebabkan terjadinya kejahatan sosial;

c. Lemah sosial: termasuk golongan masyarakat yang kurang mampu secara ekonomis atau secara finansial tidak mampu melindungi diri sendiri, dan termasuk golongan yang tidak mempunyai perlindungan; ${ }^{18}$

Faktor yang bersifat eksternal (dari luar diri si korban) terdiri dari:

a. Situasi dan kondisi tempat kejadian perkara, seperti wilayah terpencil yang prasarana jalannya kurang memadai serta sulit dijangkau, wilayah pemukiman yang pada waktu-waktu tertentu sepi dari keramaian;

\footnotetext{
17 Undang-Undang No. 21 tahun 2007 tentang Pemberantasan Tindak Pidana Perdagangan Orang

18 Arif Gosita, Relevansi Viktimologi dengan Pelayanan terhadap Para Korban Perkosaan (Beberapa Catatan), (Jakarta: Ind Hill-Co, 1987), h,13-14
} 
b. Pelaku pada umumnya mereka yang pernah mempunyai kontak sosial atau relasi sosial dengan korban meskipun tidak berarti harus saling kenal, misal: hubungan sebagai saudara dekata/jauh, hubungan sebagai murid-guru, hubungan sebagai bawahan-atasan, hubungan pembantumajikan dan hubungan sebagai pacar;

c. Nilai-nilai yang keliru di dalam masyarakat antara lain:

1. Dalam kaitannya dengan kekerasan dalam rumah tangga antara lain:

a) Suami berhak mempermalukan isteri sesuai dengan keinginannya ketika memasuki perkawinan, laki-laki sering beranggapan bahwa perempuan adalah miliknya seutuhnya yang boleh diperlakukan semaunya termasuk kekerasan dan memukul isteri;

b) Tindakan kekerasan seksual terjadi karena isteri yang memicu kemarahan suami;

c) Apabila ada pertengkaran suami-isteri, orang lain tidak boleh ikut campur tangan meskipun bila terjadi tindak kekerasan oleh suami;

d) Isteri yang menjadi korban kekerasan seksual beranggapan bahwa bercinta dengan orang lain tentang perlakuan yang dialaminya adalah sesuatu yang tabu yang dapat merusak nama baik suami dan keluarga; ${ }^{19}$

2. Kencan sebagai pertanda memperbolehkan dilakukannya aktivitas seksual terhadap wanita. Disamping itu juga mau diajak keluar rumah untuk kencan, menonton pertunjukan atau film, pergi ke restoran untuk makan malam, mengkonsumsi minuman beralkohol atau obatobatan terlarang dianggap sebagai alasan untuk memperbolehkan dilakukannya aktivitas seks terhadap wanita; ${ }^{20}$

d. Perkembangan ilmu pengetahuan dan teknologi terutama penemuan alat kontrasepsi seiring dengan menurunnya agama yang mempengaruhi pendapat anggota masyarakat tentang seks. Seks tidak lagi dipandang sebagai sesuatu yang sakral. Hal ini dapat berakibat pada perilaku seksual masyarakat makin bebas, tidak terikat pada norma-norma yang berlaku yang dapat berakibat terjadinya penyimpangan-penyimpangan seksual; $^{21}$

19 Mohammad Hakimi, Membisu demi Harmoni "Kekerasan Terhadap Istri Dan Kesehatan Perempuan di Jawa Tengah, Indonesia, (Yogyakarta: LPKGM-FK-UGM 2001), h. 4, Cet 1.

${ }^{20}$ Mohammad Hakimi, Membisu demi Harmoni "Kekerasan Terhadap Istri Dan Kesehatan Perempuan di Jawa Tengah, Indonesia, (Yogyakarta: LPKGM-FK-UGM 2001), h. 6, Cet 1.

${ }^{21}$ Sulistyanta, "Problem Penegakan Hukum Tindak Pidana Pornografi Di Era Global," (Jurnal Ilmu Hukum, Vol.9, No.1, Maret 2006), h. 54 
e. Marjinalisasi kelompok atau kelas tertentu dalam masyarakat perkotaan membentuk kultur tertentu yang memiliki norma-norma tertentu yang berbeda dari aturan-aturan yang dianut oleh masyarakat pada umumnya. Contoh, kultur anak jalanan, kultur buruh migran. Anak jalanan perempuan seringkali menjadi obyek pelecehan seksual, kekerasan seksual dan eksploitasi seksual;

f. Pengobatan alternatif dengan menggunakan cara-cara magis tertentu atau pengajaran ilmu dan menggunakan cara-cara magis tertentu membuka peluang terhadap orang-orang tertentu untuk melakukan kejahatankejahatan seksual tanpa disadari oleh para wanita yang menggunakan jasa pelayanan;

g. Kerusuhan massa yang terjadi disuatu daerah dapat memicu terjadinya pelecehan seksual atau kekerasan seksual terhadap wanita dari kelompok, kelas, penganut agama, etnis tertentu dari masyarakat yang bersangkutan karena alasan emosional kecemburuan dan lain sebagainya, misal: kerusuhan sampit, kerusuhan Mei 1998;22

\section{Dampak Kejahatan Seksual}

Kejahatan seksual cenderung menimbulkan dampak negatif secara fisik, psikologis, dan juga sosial. Dampak fisik yang biasa ditimbulkan akibat kejahatan seksual adanya memar, luka, bahkan robek pada bagian-bagian tertentu. Dampak kejahatan seksual terhadap perempuan cukup serius bagi perempuan itu sendiri, dampaknya dapat dibedakan menurut sifat dan waktu:

a. Dampak menurut sifat, dampak fisik dapat berupa luka-luka, cacat permanen hingga kematian, dampak psikologis dapat berupa perasaan tertekan, depresi, hilangnya rasa percaya diri, trauma bahkan gangguan jiwa, dampak sosial dapat berupa dikucilkan dari masyarakat;

b. Dampak menurut waktu, dampak jangka pendek, biasanya dialami beberapa saat hingga beberapa hari, secara fisik muncul dalam bentuk gangguan pada organ reproduksi (infeksi dan kerusakan selaput dara) luka-luka pada bagian tubuh yang lain, dampak secara psikologis, biasanya korban merasa bersalah sangat marah, jengkel, merasa bersalah, malu dan terhina, kadang-kadang gangguan ini bisa menyebabkan insomnia dan kehilangan nafsu makan. Dampak jangka panjang, biasanya dapat berupa sifat atau pesepsi yang negatif diri sendiri

22 Juliandry Hutahaean, "Dampak Kerusuhan Mei 1998 Terhadap Pengusaha Etnis Tionghoa di Petukangan Jakarta Tahun 1998-2003," (Journal Of Indonesian History,Vol.3 No.1 Tahun 2014), h.29 
maupun terhadap laki-laki, dampak ini terjadi apabila korban tidak mendapatkan penanganan dan bantuan yang memadai. ${ }^{23}$

\section{Karakteristik Kejahatan Seksual}

Karakteristik utama tindak pidana kejahatan seksual adalah perwujudan keinginan tentang tindak tindak seksual yang dilakukan secara agresif, bersifat menyerang dan memaksa pihak lain yang dapat dan mampu memenuhi kepentingan nafsunya dalam masalah seksual. Dan karakteristik umum tindak pidana kejahatan seksual adalah. ${ }^{24}$

a. Agresivitas, merupakan sifat yang melekat pada kejahatan seksual.

b. Motivasi kekerasan lebih menonjol dibandingkan motivasi seksual

c. Secara psikologis, kejahatan seksual yang dibatasi dengan tindak pidana perkosaan, lebih banyak mengandung masalah control dan kebencian dibandingkan dengan hawa nafsu.

Karakteristik pelaku terhadap kejahatan seksual, seringkali mengalami pengalaman buruk khususnya dalam hubungan asmara (cinta), terasing dalam pergaulan sosial, rendah diri, ada ketidak seimbangan emosional, dan kejahatan seksual ini merupakan partisipatif (kelalaian) korban, hal tersebut bisa dikatakan, seorang pelaku yang melakukan kejahatan seksual dengan seorang perempuan yang bukan istrinya adalah perbuatan yang sudah menyalahi aturan karena pelaku memaksa korban untuk tunduk agar bisa memenuhi hawa nafsunya atau menggunakan kelemahan perempuan. ${ }^{25}$

Karakteristik yang terdapat dalam diri korban mengakibatkan tidak semuah kejahatan seksual terhadap kaum wanita yang terjadi itu dilaporkan kepada aparatt penegak dan tidak semuanya diselesaikan melalui sistem peradilan pidana karena tidak semuanya berhasil mengatasi kerugian fisik, psikis dan sosial kemasyarakatan yang diakibatkan oleh kejahatan-kejahatan seksual tersebut. Hal demikian ini mengakibatkan respon atau reaksi negatif dari pihak yang dirugikan terhadap kejahatan-kejahatan seksual tersebut terutama reaksi korban, dan kebanyakan korban tidak melaporkan peristiwa tersebut ke aparat penegak hukum karena alasan enggan dan malu untuk melapor. ${ }^{26}$

${ }^{23}$ M. Anwar Fuadi, Dinamika Psikologis Kekerasan Seksual: Sebuah Studi Fenomenologi,( Jurnal Psikologi Islam, Vol 8 No 2 Tahun 2011), h. 194

${ }^{24}$ Romli Anmasasmita, Teori dan Kapita Selekta Kriminologi , (Bandung: PT Eresco, 1992), h. 108

${ }^{25}$ http://kukuhhendrakusuma15.blogspot.co.id/2013/12/makalah-kriminologi.html?m=1

${ }_{26}$ Bambang Dwi Baskoro, Kajian Kritis Terhadap Peraturan Perundang-undangan Hukum Pidana yang Mengatur Mengenai Kejahatan-Kejahatan Seksual Terhadap Kaum Wanita dan Dampaknya Terhadap Korban Kejahatan-Kejahatan Seksual, (Semarang: Univerisatas Diponegoro, 2001), h. 241. 
Salah satu untuk mengakhiri kekerasan terhadap perempuan, telah mendorong kelompok perempuan mengusung UU Penghapusan Kekerasan khususnya dalam Rumah Tangga, serta mengkriminalisasi segala bentuk kekerasan, baik fisik atau psikis, terhadap seluruh anggota keluarga di dalam rumah tangga. UU ini disahkan pada tanggal 14 September 2004, sebelum anggota Parlemen yang baru dilantik menjadi Anggota DPR RI. Sebelum disahkan, UU ini sebelumnya telah direncanakan sejak tahun 1999 dalam sebuah pertemuan yang mengeluarkan Deklarasi Komitmen pada November 1999 oleh masyarakat sipil untuk menghapuskan segala bentuk kekerasan terhadap perempuan. Berdasarkan kepada Deklarasi Komitmen tersebut, Kementerian Pemberdayaan Perempuan memfasilitasi Program Rencana Nasional Penghapusan Segala Bentuk Kekerasan terhadap Perempuan selama periode tahun 2001-2005, yang didukung oleh hampir 150 organisasi masyarakat sipil, perwakilan PBB dan kelompok-kelompok pemerhati lainnya. Singkat kata, pengesahan UU PKDRT tersebut tidak luput dari dorongan dan desakan dari masyarakat sipil, terutama kelompok perempuan yang secara kontras memiliki pandangan dan paradigma berbeda dari mayoritas masyarakat Indonesia terkait relasi antara suami dan isteri di dalam rumah tangga. ${ }^{27}$

\section{Deskripsi Kasus Pelecehan Seksual Dalam Transportasi Umum}

Dalam putusan No. 753/PID.B/2014/PN.JKT.PST, tentang tindak pidana pelecehan seksual yang dilakukan dalam transportasi umum, penulis mengambil data perkara dari Pengadilan Negeri Jakarta Pusat yang berhubungan dengan tindak pidana Pelecehan Seksual. Dalam kasus ini Edwin Kurniawan Lingga alias Edwin dan Dharman L Sitorus masing-masing bekerja sebagai petugas Pam Halte Busway Harmoni.

\section{Kasus Posisi}

Perkara ini, berkaitan dengan pelecehan seksual. Awalnya pada hari senin tanggal 20 Januari 2014 sekitar jam 06.00 saksi korban Yufika Febryana naik kendaraan transjakarta (busway) dari RS.Islam Cempaka Putih Jakarta Pusat namun sampai di fly over senen saksi korban merasa pusing dan lemas sampai pingsan dan baru tersadar di Halte Busway Harmoni, saat itu saksi korban dibantu oleh terdakwa Edwin Kurniawan Lingga dengan mempersilahkan saksi korban untuk duduk di dekat gate masuk, saat itu terdakwa sempat bertanya kepada saksi korban mengenai keadaan saksi korban yang dijawab saksi korban lemas, kemudian tidak lama mengobrol dengan terdakwa Edwin, datang terdakwa Dharman L Sitorus dan saksi Ifan Lutfi Akbar yang menegur saksi

${ }^{27}$ Asep Syarifuddin Hidayat. "Pengaruh Wacana Gender Dalam Pembangunan Hukum Keluarga di Indonesia” JURNAL CITA HUKUM [Online], Volume 1 Number 1 (1 Juni 2013), h. 133. 
korban. Selanjutnya karena saksi korban masih merasa pusing maka saksi korban dipapah oleh terdakwa Dharman, sedangkan terdakwa Edwin berjalan lebih dulu di depan saksi korban menuju ruangan genset yang ada di dalam halte busway tersebut. Sesampainya di ruangan genset saksi korban duduk di atas batu dekat mesin genset sedangkan terdakwa Dharman berada disebelah kanan saksi korban dan terdakwa Edwin berada di depan saksi korban, lalu Edwin memijat kaki kanan saksi korban dan terdakwa Dharma memijit tangan kanan dan kepala saksi korban selanjutnya terdakwa Edwin pindah posisi ke belakang saksi korban sambil memegang leher dan mengoleskan aroma terapi (freshcare), saat itu juga terdakwa Edwin memasukan tangannya kedalam baju saksi korban dan meraba payudara sebelah kanan, saat itu saksi korban sempat berontak namun karena kondisi badan saksi korban lemas sehingga tidak dapat berbuat apa-apa.

Kemudian saksi Ifan Lutfi Akbar (terdakwa dalam berkas perkara terpisah) masuk ke ruangan genset tempat saksi korban berada dan menghampiri saksi korban kemudian memijat pundak dan mengoleskan aroma terapi (freshcare) milik saksi korban kemudian memasukan tangan kanannya ke dalam baju saksi korban dan meraba payudara kanan, saksi korban sempat berontak tapi karena keadaan yang tidak berdaya sehingga tidak bisa berbuat apa-apa.

Beberapa saat kemudian datang saksi M. Kurniawan (terdakwa dalam berkas perkara terpisah) langsung menghampiri saksi korban dan memijit pundak saksi lalu memasukan tangannya kedalam baju saksi korban dan meraba payudara sebelah kiri saksi korban, kemudian saksi korban dibantu berdiri oleh saksi M. Kurniawan, Edwin langsung memangku saksi korban sedangkan kepala saksi korban berada di pundak Dharman dan mencium bibir saksi korban, sedangkan saksi M. Kurniawan berada di depan saksi korban mengangkat baju saksi korban pada bagian depan leher dan mengangkat pakaian dalam (bra) saksi korban sampai di atas dada lalu saksi M. Kurniawan menghisap payudara sebelah kiri saksi korban dan bergantian dengan Dharman untuk menghisap payudara saksi korban.

Tidak lama saksi Ifan menghampiri saksi lagi dan langsung mencium bibir saksi korban, selanjutnya ifan memegang tangan kanan saksi korban kemudian mengarahkannya ke bagian depan resleting celana saksi Ifan, lalu Ifan mengeluarkan alat kelaminya dan menggesek-gesekan ke mulut saksi korban sampai mengeluarkan sperma, kemudian tidak berapa lama datang saksi Ria Apriani yang menegur saksi korban dan Dharman.

\section{Dakwaan dan Tuntutan Jaksa}

Bahwa terdakwa Edwin Kurniawan Lingga dan Dharman L Sitorus, didakwa oleh Jaksa Penuntut Umum dengan dakwaan Priamair yaitu telah 
melanggar pasal 290 ke 1 KUHP Jo Pasal 55 ayat (1) ke 1 KUHP. Jaksa pun mendakwa terdakwa dengan dakwaan subsidernya padal pasal 281 ke-1 KUHP jo pasal 55 ayat (1) ke-1 KUHP.

Setelah Jaksa Penuntut Umum mengamati dan mencermati kasus ini, maka terdakwa dituntut oleh Jaksa Penuntut Umum dengan pasal 290 dan pasal 55 KUHP. Jaksa penuntut umum menuntut agar Majelis Hakim menjatuhkan putusan. Pertama, menyatakan terdakwa Edwin Kurniawan Lingga dan Dharman L Sitorus, bersalah melakukan tindak pidana pelecehan seksual, sebagaimana diatur dan diancam pidana yang termuat dalam pasal 290 KUHP. Kedua, yaitu menjatuhkan pidana penjara terhadap terdakwa Edwin Kurniawan Lingga dan Dharman L Sitorus, selama 1 (satu) tahun dan 6 (enam) bulan, dikurangi selama terdakwa berada dalam masa tahanan. Ketiga, yakni menetapkan agar terdakwa membayar biaya perkara masing-masing sebesar Rp. 2.000,- (dua ribu rupiah)..$^{28}$

\section{Putusan Hakim Pengadilan Negeri Jakarta Pusat dalam Perkara Pelecehan Seksual}

Pengadilan Negeri yang memeriksa dan mengadili perkara pidana dengan nomor perkara: 753/PID.B/2014/PN.JKT.PST, dan selama terdakwa dalam masa tahanan oleh penyidik sejak tanggal 03 Februari 2014. Setelah mendengar pembacaan surat dakwaan, keterangan saksi-saksi dan terdakwa, setelah melihat dan meneliti barang bukti yang diajukan dalam persidangan oleh penuntut umum. Menimbang bahwa dalam dakwaan primair, terdakwa didakwa melakukan tindak pidana sebagaimana yan diatur dalam pasal 290 ke-1 KUHP jo pasal 55 ayat (1) ke-1 KUHP, dan majelis hakimpun menimbang dan menyatakan terdakwa terbukti bersalah karena melakukan kejahatan. Yaitu sebagaiman yang diatur dan diancam dalam pasal 209 ke -1 KUHP jo pasal 55 ayat (1) ke-1 KUHP, adapun terhadap terdakwa terdapat hal-hal yang meringankan dan memberatkan terdakwa. Hal-hal yang memberatkan para terdakwa yaitu pertama, perbuatan para terdakwa membuat korban trauma. Kedua, para terdakwa adalah petugas pelayanan publik yang seharusnya memberi pelayanan yang tidak bertentangan dengan norma kesusilaan. Ketiga, para terdakwa memberikan keterangan berbelit-belit sehingga menyulitkan jalannya pemeriksaan perkara. Adapun hal-hal yang meringankan terdakwa diantaranya terdakwa belum pernah dihukum.

Berdasarkan fakta-fakta diatas akan dipertimbangkan apakah terdakwa terbukti bersalah melakukan tindak pidana sebagaimana didakwakan oleh Jaksa Penuntut Umum kepada terdakwa, terdakwa dihadapan dipersidangan dengan bentuk dakwaan primair yaitu melanggar pasal 290 ke-1 KUHP jo pasal 55 ayat

${ }^{28}$ Putusan Pengadilan Negeri Jakarta Pusat, No. 753/PID.B/2014/PN.JKT.PST 
(1) ke-1 KUHP. Jaksa juga mendakwa dengan dakwaan subsidair yaitu melanggar pasal 281 ke-1 KUHP jo pasal 55 ayat (1) ke-1 KUHP.

Berdasarkan fakta-fakta dalam persidangan Pengadilan Negeri Jakarta Pusat, maka hakim mempertimbangkan mengenai unsur-unsur tindak pidana yang didakwakan, sebagaimana yang diatur dan diancam dalam pasal $290 \mathrm{ke}-1$ KUHP jo pasal 55 ayat (1) ke-1 KUHP, yang unsur-unsurnya sebagai berikut:

1. Barang siapa;

2. Melakukan perbuatan cabul dengan seseorang;

3. Padahal diketahuinya bahwa orang itu pingsan atau tidak berdaya;

4. Melakukan, menyuruh melakukan dan turut serta melakukan.

Adapun yang dimaksud dengan "barang siapa" adalah setiap orang yang dapat dijadikan sebagai subyek hukum, dari padanya dapat dimintakan pertanggungjawaban pidana, dalam hal ini telah terpenuhi dengan dihadapkannyya terdakwa bernama Edwin Kurniawan Lingga dan Dharman L Sitorus ke persidangan, dalam keadaan sehat jasmani maupun rohaninya serta mampu mempertanggungjawabkan segala perbuatannya secara hukum.

Bahwa berdasarkan fakta-fakta dipersidangan, Majelis Hakim berkesimpulan bahwa terdakwa Edwin Kurniawan Lingga dan Dharman L Sitorus terbukti secara sah melakukan tindak pidana " turut serta melakukan perbuatan cabul dengan seseorang padahal diketahuinya bahwa orang itu tidak berdaya".

Setelah hakim mengingat pasal 290 ke-1 KUHP jo pasal 55 ayat (1) ke-1 KUHP dan unsur-unsur dalam pasal 290 telah terbukti, maka hakim menyatakan dan menetapkan bahwa terdakwa Edwin Kurniawan Lingga dan Dharman L Sitorus telah terbukti dan meyakinkan hakim terdakwa bersalah melakukan tindak pidana " turut serta melakukan perbuatan cabul dengan seseorang padahal diketahuinya bahwa orang itu tidak berdaya". Maka hakim menjatuhkan hukuman pidana penjara 1 (satu) tahun dan 6 (enam) bulan, dan membebankan kepada terdakwa membayar biaya perkara masing-masing sebesar Rp. 2000,- (dua ribu rupiah).

\section{Analisis Putusan Pengadilan Negeri Jakarta Pusat dalam Perkara Tindak Pidana Pelecehan Seksual Menurut Hukum Positif dan Hukum Islam}

Adapun fakta yang terungkap dipersidangan, berdasarkan saksi, maupun barang bukti yang diajukan serta keterangan terdakwa. Barang bukti berupa 1 (satu) buah baju warna merah hati polos berenda yang terdapat noda sperma, 1 (satu) buah aroma therapy merek freshcare dan 1 (satu) buah celana 
jeans pendek warna biru adalah milik korban. Barang bukti tersebut dikembalikan kepada pemiliknya.

Berdasarkan semua fakta yang telah terungkap dipersidangan, maka dapatlah dianalisis bahwa kejadian pelecehan seksual yang terjadi di dalam bus transjakarta yang dilakukan oleh Edwin Kurniawan Lingga dan Dharman L Sitorus dapat dikatakan sebagai tindak pidana turut serta melakukan perbuatan cabul dengan seseorang padahal diketahuinya bahwa orang itu tidak berdaya, yang membuat korban trauma.

Pengertian perbuatan cabul dengan orang pingsan menurut Kitab Undang-undang Hukum Pidana (KUHP) tentang pencabulan diatur dalam pasal 290 ke-1 KUHP yang berbunyi barang siapa melakukan perbuatan cabul dengan seseorang yang diketahuinya bahwa orang itu pingsan atau tidak berdaya. Kata pingsan disinonimkan dengan kata-kata tidak sadar, tidak ingat, sedangkan kata tidak berdaya adalah tidak bertenaga atau sangat lemah dan kata diketahuinya adalah rumusan sengaja, dengan demikian terdakwa mengetahui bahwa yang dicabulinya tersebut dalam keadaan pingsan atau tidak sadar.

Adapun mengengai sanksi pidananya diterangkan dalam pasal 290 ke 1 KUHP yang berbunyi "Diancam dengan pidana penjara paling lama tujuh tahun. Barang siapa melakukan perbuatan cabul dengan seorang, padahal diketahuinya bahwa orang itu pingsan atau tidak berdaya". Dalam kerangka berfikir hukum, ada tiga aspek nilai-nilai hukum yang menjadi tolak ukur seorang hakim untuk memutuskan sebuah perkara yaitu: putusan hakim harus mengandung nilai-nilai keadilan hukum, keadilan hukum adalah memberikan hukuman kepada seseorang sesuai dengan perbuatannya, putusan hakim harus mengandung nilainilai kegunaan hukum, aspek kegunaan hukum adalah terwujudnya ketertiban, dan putusan tersebut harus mengandung nilai kepastian hukum, kepastian hukum memiliki arti perangkat hukum suatu Negara yang mampu menjamin hak dan kewajiban setiap warga Negara.

Dalam kerangka tiga tolak ukur tersebut dalam menilai suatu putusan hakim maka suatu proses hukum dalam perkara pidana haruslah mengungkapkan sedalam-dalamnya tentang fakta telah terjadinya suatu tindak pidana dan pertimbangan hukum yang termuat dalam putusan hakim. Untuk itulah, dalam kajian putusan hakim Pengadilan Negeri Jakarta Pusat dengan Nomor perkara: 753/PID.B/2014/PN.JKT.PST, yang memfokuskan pada penilaian terhadap fakta persidangan dan pertimbangan hukum dalam putusan tersebut dengan mengacu pada tiga tolak ukur di atas.

Berdasarkan fakta dipersidangan yang ada dalam Pengadilan Negeri Jakarta Pusat dengan Nomor perkara 753/PID.B/2014/PN.JKT.PST. Majelis Hakim berpendapat bahwa terdakwa telah terbukti secara sah dan meyakinkan bersalah melakukan perbuatan sebagaimana dalam dakwaan penuntut umum, karena itu terdakwa harus dipidana sesuai ketentuan undang-undang yang 
berlaku. Dalam hal ini para terdakwa dikenakan pasal 290 ke 1 KUHP jo pasal 55 ayat (1) ke $1 \mathrm{KUHP}$, sesuai dengan dakwaan Jaksa Penuntut Umum.

Putusan yang dijatuhkan oleh Majelis Hakim tersebut dilihat dari aspek keadilan, dari sisi terdakwa sudah dapat dikatakan sesuai dengan nilai keadilan, karena dari fakta-fakta yang terungkap dipersidangan, bahwa terdakwa telah terbukti melakukan tindak pidana turut serta melakukan perbuatan cabul dengan seseorang padahal diketahuinya bahwa orang itu tidak berdaya, sebagaimana yang didakwakan kepadanya, sehingga memang tepat Majelis Hakim menjatuhkan Putusannya yaitu:

1. Menyatakan dan menetapkan bahwa terdakwa Edwin Kurniawan Lingga dan Dharman L Sitorus terbukti secara sah dan meyakinkan hakim bahwa terdakwa bersalah melakukan tindak pidana turut serta melakukan perbuatan cabul dengan seseorang padahal diketahuinya bahwa orang itu tidak berdaya.

2. Menjatuhkan hukuman pidana kepada Edwin Kurniawan Lingga dan Dharman L Sitorus selama 1 (satu) tahun dan 6 (enam) bulan

3. Membebankan terdakwa membayar biayar perkara sebesar Rp. 2000,(dua ribu rupiah).

Dari putusan yang dijatuhkan Majelis hakim kepada terdakwa tersebut diatas dilihat dari aspek keadilan, dari sisi hakim dapat dikatakan keputusan itu memenuhi nilai keadilan, karena keputusannya itu diambil atas dasar hukum yang pasti dapat diterima, sehingga apa yang diputuskan itu sungguh-sungguh dapat dipertanggungjawabkan.

Aspek kegunaan hukum adalah terwujudnya ketertiban, maka berbagai keperluan sosial manusia dalam masyarakat dapat terpenuhi. Untuk mewujudkan ketertiban manusia memunculkan keharusan-keharusan berperilaku dengan cara tertentu yang dirumuskan dalam kaidah. Ketertiban kaidah yang diperlukan manusia adalah ketertiban yang otentik menciptakan manusia secara wajar mewujudkan kepribadiannya secara utuh, yang dengan itu ia dapat mengembangkan semua potensi kemanusiaan seperti apa yang secara bebas dikehenakinya. ${ }^{29}$

Dalam hal ini Majelis hakim berpandangan bahwa perkara ini adalah termasuk kedalam tindak pidana turut serta melakukan perbuatan cabul dengan seseorang padahal diketahuinya bahwa orang itu tidak berdaya. Karena itu, unsur-unsur yang terdapat pada pasal 290 ke 1 KUHP jo pasal 55 ayat (1) ke 1 KUHP telah terbukti menurut hukum. Dengan demikian para terdakwa harus dinyatakan terbukti bersalah atas dakwaan primair dan para terdakwa dipidana

${ }^{29}$ Johny Ibrahim, Teori dan Metode Penelitian Hukum Normatif, (Malang: Bayumdia, 2005), h. 
dari dakwaan tersebut. Kepastian memiliki arti ketentuan dan ketetapan. Sedangkan, kepastian hukum memiliki arti perangkat hukum suatu Negara yang mampu menjamin hak dan kewajiban setiap Negara.

Berdasarkan fakta yang terungkap dalam persidangan, pada putusan Pengadilan Negeri Jakarta Pusat dengan Nomor: 753/PID.B/2014/PN.JKT.PST, apa yang didakwakan kepada terdakwa, yaitu dakwaan primair berupa tindak pidana turut serta melakukan perbuatan cabul dengan seorang, padahal diketahuinya bahwa orang itu pingsan atau tidak berdaya yang diatur dan diancam dalam pasal 290 ke 1 KUHP jo pasal 55 ayat (1) ke 1 KUHP dan dakwaan subsidiair yang diatur dan diancam dalam pasal 281 ke 1 KUHP jo pasal 55 ayat (1) ke 1 KUHP. Berdasarkan hal tersebtu, untuk menentukan apakah terdakwa dapat dinyatakan bersalah melakukan tindak pidana, sebagaimana yang didakwakan dinyatakan bersalah melakukan tindak pidana, sebagaiman yang didakwakan atasnya, terlebih dahulu harus dibuktikan dakwaan primairnya. Apabila dakwaan primairnya tidak terbukti maka berlanjut pada dakwaan subsidiair.

Sebagaimana yang termuat dalam putusan Pengadilan Negeri Jakarta Pusat dengan Nomor perkara : 753/PID.B/2014/PN.JKT.PST, dakwaan primair berupa tindak pidana turut serta melakukan perbuatan cabul dengan seseorang padahal diketahuinya bahwa orang itu tidak berdaya yang diatur dan diancam pidana dalam pasal 290 ke 1 KUHP jo pasal 55 ayat (1) ke 1 KUHP yang unsurunsurnya yaitu ada 2 (dua) unsur yang harus dipenuhi untuk penetapan hukuman, yaitu pertama unsur subyektif terdiri dari, unsur barang siapa. Adapun unsur yang kedua yaitu unsur obyektif yang terdiri dari unsur melakukan perbuatan cabul dengan seseorang padahal diketahuinya bahwa orang itu pingsan atau tidak berdaya.

Mengenai unsur "barang siapa" adalah setiap orang yang dapat dijadikan sebagai subyek hukum, dari padanya dapat dimintakan pertanggungjawaban pidana, dalam hal ini telah terpenuhi dengan dihadapkannya terdakwa bernama Edwin Kurniawan Lingga dan Edwin L Sitorus ke persidangan, dalam keadaan sehat jasmani maupun rohaninya serta mampu mempertanggungjawabkan segala perbuatannya secara hukum.

Melakukan perbuatan cabul dengan seseorang padahal diketahuinya bahwa orang itu pingsan atau tidak berdaya.

Majelis hakim dalam kontruksi hukum dalam kasus ini, terlihat telah menerapkan kepastian hukum, dengan melihat unsur-unsur tindak pidana. Karena, hakim menurut penulis telah menerapkan asas legalitas yang di identikan dengan kepastian hukum. Mejelis hakim juga telah memberikan perlindungan terhadap warga Negara dari tindakan kejahatan. Sebagaiman ciri suatu Negara hukum adalah adanya perlindungan undang-undang dasar 1945 dinyatakan bahwa Indonesia adalah Negara yang berdasarkan atas hukum, tidak 
berdasarkan kesewenangan belaka, sehingga hukumlah yang mempunyai arti yang terutama dalam segala segi-segi penghidupan masyarakat.

Dalam hukum Islam seseorang yang melakukan perbuatan tindak pidana, sanksi atau hukumannya harus ditunjukan kepada si pelaku yang besangkutan dan tidak dapat dikaitkan atau ditanggung oleh siapapun baik itu keluarganya, saudara atau kerabatnya sekalipun. Seperti apa yang tercantum dalam firman Allah surat Al-Baqarah ayat 286:

Allah tidak membebani seseorang melainkan sesuai dengan kesanggupannya. ia mendapat pahala (dari kebajikan) yang diusahakannya dan ia mendapat siksa (dari kejahatan) yang dikerjakannya. (mereka berdoa): "Ya Tuhan Kami, janganlah Engkau hukum Kami jika Kami lupa atau Kami tersalah. Ya Tuhan Kami, janganlah Engkau bebankan kepada Kami beban yang berat sebagaimana Engkau bebankan kepada orang-orang sebelum kami. Ya Tuhan Kami, janganlah Engkau pikulkan kepada Kami apa yang tak sanggup Kami memikulnya. beri ma'aflah kami; ampunilah kami; dan rahmatilah kami. Engkaulah penolong Kami, Maka tolonglah Kami terhadap kaum yang kafir." (Q.S. Al-Baqarah : 286)

Ayat di atas menegaskan bahwasanya hukuman pidana tidak dapat dialihkan kepada orang lain ataupun kepada keluarga terdakwa, sanksi diberikan hanya kepada si pelaku tindak pidana atau yang melakukan perbuatan melanggar hukum. ${ }^{30}$ Pelecehan seksual merupakan perilaku atau tindakan yang mengganggu melecehkan dan tidak diundang yang dilakukan oleh seseorang atau kelompok orang terhadap pihak lain yang berkaitan langsung dengan jenis kelamin pihak yang di ganggunya dan dirasakan menurunkan martabat dan harga diri orang yang diganggunya.

Terkait pelecehan seksual, dalam Alquran dan Hadis tidak ada penjelasan secara spesifik tentang pelecehan seksual yang ada hanya penjelasan tentang zina dan perkosaan dalam surat Al-Isra ayat 32 yang berbunyi: Dan janganlah kamu mendekati zina; Sesungguhnya zina itu adalah suatu perbuatan yang keji. dan suatu jalan yang buruk. (Q.S. Al-Isra : 32)

Sebagaimana telah disinggung ayat ini berisi larangan terhadap zina dan apa saja yang mengarah pada zina, sehingga pengertian yang dicakup oleh ayat ini tidaklah sebatas bersenggama saja. Ungkapan yang berbunyi (janganlah kamu mendekati zina) mempunyai arti tidak boleh melakukan apa saja yang biasanya menjadi pendahuluan atau bisa mengarah pada zina, seperti memandang lawan jenis dengan penuh syahwat, berduaan ditempat sepi, meraba, mengelus, menggerayangi, mencium, kencan dengan pasangan selingkuh, dan sebagainya.

Katakanlah: "Tiadalah aku peroleh dalam wahyu yang diwahyukan kepadaKu, sesuatu yang diharamkan bagi orang yang hendak memakannya, kecuali kalau

${ }^{30}$ Ahmad Hanafi, Asas-asas Hukum Pidana Islam, (Jakarta : Bulan Bintang, 2005), h. 87. Cet Ke-VI. 
makanan itu bangkai, atau darah yang mengalir atau daging babi - karena Sesungguhnya semua itu kotor - atau binatang yang disembelih atas nama selain Allah. Barangsiapa yang dalam Keadaan terpaksa, sedang Dia tidak menginginkannya dan tidak (pula) melampaui batas, Maka Sesungguhnya Tuhanmu Maha Pengampun lagi Maha Penyayang".

Ibnu Qayyim mengisahkan ayat ini dijadikan hujjah oleh Ali bin Abi Thalib ra di hadapan Khalifah Umar bin Khattab ra untuk membebaskan seorang perempuan yang dipaksa berzina oleh seorang penggembala, demi mendapat air minum karena perempuan itu sangat kehausan. ${ }^{31}$ Adapun dalil sunnah adalah sabda Nabi SAW, “Telah diangkat dari umatku (dosa/sanksi) ketidaksengajaan, karena lupa, dan karena apa-apa yang dipaksakan atas mereka." (HR.Thabrani dari Tsauban RA. Imam Nawawi berkata, "ini hadits hasan") ${ }^{32}$. Jika seorang wanita disetubuhi secara paksa, maka tidak ada hukuman had baginya, sesuai firman Allah dalam surat Al-Baqarah ayat 173 yang berbunyi:

Sesungguhnya Allah hanya mengharamkan bagimu bangkai, darah, daging babi, dan binatang yang (ketika disembelih) disebut (nama) selain Allah. tetapi Barangsiapa dalam Keadaan terpaksa (memakannya) sedang Dia tidak menginginkannya dan tidak (pula) melampaui batas, Maka tidak ada dosa baginya. Sesungguhnya Allah Maha Pengampun lagi Maha Penyayang. (Q.S. Albaqarah : 173).

Tidak ada seorang pun yang menyelisihkannya, tetapi mereka berbeda pendapat tentang wajibnya mahar baginya, Imam Malik dan Imam Syafi'I berpendapat wajibnya mahar baginya, sedangkan Imam Hanafi berpendapat tidak wajib mahar baginya. ${ }^{33}$

Dalam kasus di atas Yufika Febryana orang yang menjadi korban pelecehan seksual adalah orang yang dipaksa melakukan perbuatan yang tidak di inginkan korban, dan terhadap pelaku dapat ditentukan hak ganti kerugian berdasarkan $t a^{\prime} z i r$.

$T a^{\prime} z i r$ menurut bahasa berarti larangan, pencegahan, menegur, mencela, dan memukul. ${ }^{34}$ Secara syar'i ta'zir adalah hukuman yang tidak ditentukan (bentuk dan jumlahnya) yang wajib dilaksanakan terhadap maksiat yang tidak termasuk hudud dan kafarat, baik pelanggaran itu menyangkut hak Allah maupun hak pribadi, ta'zir diterapkan pada dua kejahatan, yaitu kejahatan meninggalkan kewajiban atau kejahatan melanggar larangan. ta'zir yang dijatuhkan tidak boleh melebihi hukuman had, hukuman $t a^{\prime} z i r$ bisa diberikan maksimal sedikit dibawah batas minimal hukuman had, dan hukuman ta'zir

${ }^{31}$ Abdul Qadir Audah, At Tasyri' Al Jina'I Al Islami, Juz 2. h. 365

32 Wahbah Zuhaili, Al Figh Al Islami wa Adillatuhu, Juz 7. h. 294

33 Sayyid Sabiq, Ringkasan Fikih Sunnah, (Beirut Publishing, 2014) h. 578.

${ }^{34}$ Abdul Azis Dahlan, et. Al, Ensiklopedi Hukum Islam, (Jakarta : PT Ichtiar Baru Van Hoeve, 2000), h. 1771, Cet 4. 
maksimalnya tidak boleh melebihi 10 kali cambukan, ketentuan ini merupakan salah satu pendapat dalam mazhab Ahmad dan yang lainnya. ${ }^{35}$

Melihat sanksi dari putusan yang dijatuhkan Pengadilan Negeri Jakarta Pusat Kepada terdakwa, yaitu hukuman selama 1 (satu) tahun dan 6 (enam) bulan dan membayar biaya perkara sebesar 2000,- (dua ribu rupiah), ini sesuai dengan hukum Islam yaitu berupa penjara, karena penjara adalah salah satu hukuman yang masuk kedalam kategori $t a^{\prime} z i r$.

\section{Analisis Perbandingan Tentang Pelecehan Seksual dalam Transportasi Umum Putusan No. 753/PID/B/2014/PN.JKT.PST}

Berdasarkan uraian di atas tentang putusan Pengadilan Negeri No. 753/PID/B/2014/PN.JKT.PST tentang pelecehan seksual dalam transportasi umum yang dilihat dari dua sistem hukum (Hukum Islam dan Hukum Positif), maka dalam bagian analisa ini, penulis hendak melihat titik perbedaan yang terdapat dalam ketentuan hukum Islam dan hukum positif.

Menurut hukum Islam pada kasus tersebut jelas sekali bahwa Edwin Kruniawan Lingga alias Edwin dan Dharman L Sitorus telah melakukan suatu jarîmah yaitu terdakwa melakukan perbuatan pelecehan seksual kepada Yufika Febriyana padahal diketahui saksi dalam keadaan tidak berdaya (sakit), adapun perbuatan yang dilakukan terdakwa adalah telah melakukan jarimah ta'zir yang berkaitan dengan kejahatan terhadap kehormatan dan kerusakan terhadap akhlak sehingga terdakwa dijatuhi hukuman jilid yang berlaku dalam jarimah hudud.

Pelaksanaan $t a^{\prime} z i r$ diserahkan kepada imam atau penguasa (hakim) yang akan menetapkan atau menjatuhkan hukuman. Hakim memiliki kebebasan untuk menetapkan ta'zir kepada pelaku tindak pidana atau jarimah yang ancaman hukumannya tidak ditentukan oleh nash (Alquran dan Hadits). Karena itu $t a^{\prime} z i r$ dapat berubah sesuai dengan kepentingan dan kemaslahatan. Pemberian hak penentuan $t a^{\prime} z i r$ kepada penguasa itu dimaksudkan agar mereka dapat mengatur kehidupan secara tertib dan mampu mengantisipasi berbagai kemungkinan yang akan terjadi selanjutnya.

Menurut hukum positif tentang pelecehan seksual yang dilakukan di bus transjakarta dengan terdakwa I Edwin Kurniawan Lingga alias Edwin dan terdakwa II Dharman L Sitorus belum sesuai dengan amanat Undang-undang yang berlaku di Indonesia. Dalam putusan tersebut terdakwa dijatuhi hukuman selama 1 (satu) tahun dan 6 (enam) bulan penjara, seharusnya dihukum dengan 7 (tujuh) tahun penjara. Padahal dalam perkara tersebut terdakwa telah terbukti secara sah melakukan perbuatan kejahatan kesusilaan (Bab XIV) KUHP tentang kejahatan terhadap kesusilaan yaitu (pasal 290) KUHP. Tetapi ada hal-hal yang

${ }^{35}$ Asadulloh Al-Faruq, Hukum Pidana dalam Sistem Hukum Islam, h. 78, Cet I. 
memperingan atas putusan terhadap tindak pidana yaitu terdakwa belum pernah dihukum.

\section{Kesimpulan}

Kejahatan seksual ini tidak bisa terlepas dari kehidupan manusia yang memiliki hawa nafsu karena adanya unsur yang harus dipenuhi yaitu melanjutkan dan memperbanyak keturunan untuk kelangsungan hidup. Bukan berarti manusia bisa melakukan kegiatan seksual sesuka hati, jika aktifitas seksual dilakukan di luar jalur yang ditentukan, seperti yang dilakukan oleh orang yang hanya menuruti hawa nafsunya dan keinginan mereka maka hubungan tersebut sudah masuk taraf zinah, dan bahwa zina adalah perbuatan yang dilarang oleh agama Islam yang artinya sudah melanggar hukum Allah. Sedangkan menurut hukum positif kejahatan seksual adalah Perilaku seksual menyimpang, merupakan salah satu bentuk dari berbagai bentuk penyimpangan yang ada dalam masyarakat, sehingga setiap bentuk penyimpangan seksual amat berdampak terhadap kehidupan dan keteraturan sosial dalam masyarakat. Dampak yang ditimbulkan oleh perilaku menyimpang tersebut merupakan suatu ancaman terhadap sistem norma yang ada dalam masyarakat.

Pertimbangan hakim dalam menjatuhkan putusan pelecehan seksual ini didasarkan kepada teori dan hasil penelitian yang saling berkaitan sehingga didapatkan hasil penelitian yang maksimal dan seimbang dalam tataran teori dan praktek. Maka dari itu pertimbangan hakim menjatuhkan putusan atas kasus ini melihat dari hal yang memberatkan terdakwa diantaranya, perbuatan terdakwa membuat korban trauma, terdakwa adalah petugas pelayanan publik yang seharusnya memberi pelayanan yang tidak bertentangan dengan norma kesusilaan dan terdakwa memberikan keterangan yang membingungkan sehingga menyulitkan jalannya pemeriksaan, adapun hal yang meringankan para terdakwa belum pernah dihukum.

Putusan Pengadilan Negeri Jakarta Pusat No. 753/PID.B/2014/PN.JKT.PST. Tim majelis hukum menjatuhkan vonis kepada pelaku dengan hukuman 1 (satu) tahun dan 6 (enam) bulan penjara. Dari putusan pengadilan tersebut maka jika ditinjau dari hukum Islam, hukuman yang dijatuhkan bagi terdakwa belumlah mencerminkan keadilan, sesuai yang tercantum dalam Alquran dan Hadist, hukuman itu diberikan untuk membuat pelaku jera dan tidak mengulangi perilaku yang tidak tercela itu, karena dalam kasus diatas korban merasakan trauma dan mengalami gangguan psikis yang sangat berat, adapun hukuman yang harus diberikan kepada pelaku dengan memberikan hukuman yang bisa membuat para pelaku jera.

Terkait banyaknya kasus pelecehan seksual di negeri ini belum ada kejelasan terhadap hukumannya, pelaku pelecehan seksual hanya di kenakan 
pasal pencabulan yang berada dalam delik kejahatan kesusilaan, seharusnya para penegak hukum lebih peka untuk bisa merevisi lagi KUHP, karena KUHP itu adalah warisan dari kolonial Belanda dan hanya disesuaikan saja dengan keadaan yang berada di Indonesia, saran dari penulis adalah merevisi KUHP untuk mencantumkan pasal pelecehan seksual agar bisa lebih maksimal lagi dalam penegakan hukum, karena kasus pelecehan seksual sangat merugikan kaum perempuan, apalagi Negara Indonesia adalah Negara Hukum seharusnya bisa membuat masyarakat merasa aman dari para pelaku kejahatan, penulis berharap agar para penegak hukum di Indonesia tidak tutup mata terkait banyaknya kasus pelanggaran di kalangan masyarakat yang tidak ditangani secara maksimal.

\section{Daftar Pustaka}

Adjis, A Adjis; dan Akasyah, Dudi. Kriminologi Syariah, Jakarta: Penerbit Rmbooks, 2007.

Aji, Ahmad Mukri. "Kekerasan Dalam Rumah Tangga Perspektif Hukum Positif Indonesia," dalam Salam; Jurnal Sosial dan Budaya Syar-i, Vol. 4 No. 1 (2017).

Aji, Ahmad Mukri. "Pemberatasan Tindak Pidana Terorisme di Indonesia (Analisis Terhadap Undang-Undang Nomor 15 dan 16 Tahun 2003 Berdasarkan Teori Hukum)," dalam Jurnal Cita Hukum, Vol. 1, No. 1 (2013).

Aji, Ahmad Mukri. Urgensi Maslahat Mursalah Dalam Dialektika Pemikiran Hukum Islam, Bogor: Pustaka Pena Ilahi, 2012.

Ali, Zainuddin. Hukum Islam, Pengantar Ilmu Hukum Islam di Indonesia, Jakarta: Sinar Grafika 2006

Andrisman, Tri. Asas-asas dan Dasar Aturan Hukum Pidana Indonesia, Bandar Lampung: Penerbit Unila 2009

Asmara, Romi. \& Rasyid, M Laila. Perlindungan Hukum Terhadap Anak Perempuan Korban Kejahatan Kesusilaan Di Kota Lhokseumawe

Audah, Abdul Qadir, At Tasyri' Al Jina'i Al Islami Juz 2

Bonger, W.A. Pengantar Kriminologi, Jakarta: Penerbit Ghalia Indonesia 1977

Chazawi, Adami, Tindak Pidana Mengenai Kesopanan, Jakarta: Penerbit Raja Grafindo Persada, 2005

D, Soedjono. Ilmu Jiwa Kejahatan, Bandung: Penerbit Karya Nusantara 1977

Dahlan, Abdul Azis dkk. Ensiklopedia Hukum Islam, Jakarta: Penerbit PT Ichtiar Baru Van Hoeve 2000

Djazuli, Ahmad. Fiqih Jinayah, Upaya Menanggulangi Kejahatan dalam Islam, Jakarta: Penerbit PT Raja Grafindo Persada 2000

Djubaedah, Neng. Pornografi dan Pornoaksi, ditinjau dari Hukum Islam, Bogor: Penerbit Kencana 2003 
Faruq, Al Asadulloh. Hukum Pidana dalam Sistem Hukum Islam, Jakarta: Penerbit Ghalia Indonesia 2009

Ghozali. Abdul Moqsit. Tubuh, Seksualitas, dan Kedaulatan Perempuan, Jakarta: Penerbit Rahima 2002

Gunawan, FX Rudi. Pelacur dan Politikus, Jakarta: Penerbit PT Pustaka Utama Grafiti 1997

Hakimi, Mohammad dkk. Membisu demi Harmoni, Kekerasan Terhadap Isteri dan Kesehatan Perempuan di Jawa Tengah Indonesia, Yogyakarta: Penerbit LPKGM-FK-UGM 2001

Hamzah, Andi, Delik-delik tertentu (speciale delicten) di dalam KUHP, Jakarta: Penerbit Universitas Trisakti, 2011

Hamzah, Andi. KUHP dan KUHAP, Jakarta: Penerbit PT Rineka Cipta 2004

Helmi, Muhammad. "PENGADILAN KHUSUS KDRT: “Implementasi Gagasan Sistem Peradilan Pidana Terpadu Penanganan Kasus-Kasus Kekerasan Terhadap Perempuan (SPPT-PKKTP)" JURNAL CITA HUKUM [Online], Volume 2 Number 2 (2 Desember 2014).

Ilyas, Hasyim. Orientasi Seksual dari Kajian Islam, Yogyakarta: Penerbit Pustaka Pelajar IAIN Yogyakarta 2002

Jalaludin dkk. Pengantar Ilmu Jiwa Agama, Jakarta: Penerbit CV Pustaka 1989

Jamaa, La. “Perlindungan Korban Kekerasan Dalam Rumah Tangga Dalam Hukum Pidana Indonesia" JURNAL CITA HUKUM [Online], Volume 2 Number 2 (2 Desember 2014).

Kamus Besar Bahasa Indonesia, Penerbit Balai Pustaka 1988

Lamintang, P.A.F dan Lamintang Theo, Delik-delik Khusus Kejahatan Melanggar Norma Kesusilaan dan Norma Kepatutan, Jakarta: Penerbit Sinar Grafika, 2009

Marpaung, Leden, Kejahatan terhadap kesusilaan dan masalah prevensinya, Penerbit Sinar Grafika, 1996

Marzuki, Suparman. Pelecehan Seksual, Yogyakarta: Penerbit FH UI 1995

Moeljatno. Asas-asas Hukum Pidana, Jakarta: Penerbit Aneka Cipta 1993

Muladi dan Arif, Barda Nawawi. Teori dan Kebijakan Pidana, Bandung: Penerbit Alumni, 1984

Munawir, A.W. Kamus Al-Munawir Arab-Indonesia Terlengkap, Surabaya: Penerbit Pustaka Progresif 1997

Muthahhari, Murtadha. Etika Seksual Dalam Islam, Jakarta: Penerbit PT Lentera Basritama.

Perserikatan Bangsa-Bangsa. Deklarasi tentang Kekerasan Terhadap Perempuan 21 Desember 1993

Prodjodikoro, Wirjono. Asas-asas Hukum Pidana, Bandung: Penerbit PT Refika Aditama 2003

Qardhawi. Yusuf. Halal dan Haram dalam Islam, Penerjemah Hamidy, Muamal, Surabaya: Penerbit Bina Mulya 1982 
Ramadyan, Yayah. Pelecehan Seksual (Dilihat dari Kacamata Hukum Islam dan KUHP), Skripsi Fakultas Syari'ah Dan Hukum Universitas Islam Negeri Jakarta.

Rohim, Nur. "Kontroversi Pembentukan Perppu No. 1 Tahun 2013 Tentang Mahkamah Konstitusi Dalam Ranah Kegentingan Yang Memaksa" Jurnal Cita Hukum [Online], Volume 2 Number 1 (1 June 2014).

Sabiq, Sayyid. Ringkasan Fikih Sunnah, Penerbit Beirut Publishing 2014

Saebani, Ahmad Beni. Metode Penelitian Hukum, Bandung: Penerbit Pustaka Setia, 2008.

Sahetappy, J.E. Pidana Mati Dalam Negara Pancasila, Bandung: Penerbit Citra Aditya Bakti 2007

Santoso, Topo. Membumikan Hukum Pidana Islam, Penegakan Syariat dalam Wacana dan Agenda, Jakarta: Penerbit Gema Insani Press 2003

Setiardja. A Gunawan. Dialektika Hukum dan Moral, Yogyakarta: Penerbit Kanisius 1990

Siagian, Amrizal. Pengantar Studi Kriminologi, Perkembangan Pemikiran dan Teori Kriminologi, Jakarta: Penerbit Uin Jakarta Press 2013

Sianturi, S.R, dan Pangabean L. Mompang. Hukum Penitensia di Indonesia, Jakarta: Penerbit Gunung Mulia 1997

Soejono. \& Abdurrahman H. Metode Penelitian Hukum, Jakarta: Penerbit PT. Rineka Cipta, 1999. Cet: ke-1.

Soekanto, Soerjono. Kriminologi Suatu Pengantar, Penerbit Ghalia Indah, 1986

Soesilo.R. Kriminologi, Pengetahuan Tentang Sebab-sebab Kejahatan, Bandung: PT Karya Nusantara 1985

Sugiyono. Metode Penelitian Kualitatif dan Kuantitatif, Bandung: Penerbit Alfabeta, 2004.

Suma, Muhammad Amin. Dkk. Pidana Islam di Indonesia, Peluang, Prospek, dan Tantangan, Jakarta: Penerbit Pustaka Firdaus, 2001.

Syarifuddin Hidayat, Asep. “Pengaruh Wacana Gender Dalam Pembangunan Hukum Keluarga di Indonesia" JURNAL CITA HUKUM [Online], Volume 1 Number 1 (1 Juni 2013).

Tongat. Pidana Seumur Hidup dalam Sistem Hukum Pidana Indonesia, Malang: Penerbit UMM Press 2004

Undang-undang Penyandang Cacat No. 4 Tahun 1997 Tentang Penyandang Cacat

Wahdah,. Sanksi Pidana Pelecehan Seksual antar Anak Dibawah Umur Menurut Hukum Islam dan Hukum Positif, Skripsi Fakultas Syari'ah dan Hukum Universitas Islam Negeri Jakarta.

Yunus, Nur Rohim. Restorasi Budaya Hukum Masyarakat Indonesia, Bogor: Jurisprudence Press, 2012.

Zuhaili, Wahbah, Al Figh Al Islami Wa Adillatuhu Juz 7 


\title{
Kekerasan Dalam Perkawinan dan Nusyuz Dalam Hukum Keluarga di Turki, Malaysia, Sudan, Yordan, dan Indonesia* \\ (Marriage Violence and NusyuzIn Family Law in Turkey, Malaysia, Sudan, Jordan, and Indonesia)
}

Fitriyani Zein ${ }^{1}$

Universitas Islam Negeri Syarif Hidayatullah Jakarta

doi) $10.15408 /$ sjsbs.v4i3.10290

\begin{abstract}
:
The problem of marital violence and nusyuz is a phenomenon that is always present in people's lives. In fact, this is a major problem that has been highlighted in the discourse of family law thinking in Islamic countries. In this study the authors conducted analyzes and studies in several countries including Turkey, Malaysia, Sudan, Jordan, and Indonesia. From several countries, it was found that the regulation of this problem was not fully able to provide solutions and resolve cases.
\end{abstract}

Keywords: Violence, Nusyuz, Family Law

\begin{abstract}
Abstrak:
Permasalahan tentang kekerasan dalam perkawinan dan nusyuz merupakan fenomena yang selalu ada dalam kehidupan masyarakat. Bahkan hal ini menjadi problem utama yang menjadi sorotan dalam diskursus pemikiran hukum keluarga di negara-negara Islam. Dalam penelitian ini penulis melakukan analisis dan kajian pada beberapa negara diantaranya Turki, Malaysia, Sudan, Yordan, dan Indonesia. Dari beberapa negara tersebut didapatkan bahwa pengaturan tentang permasalahan ini belum sepenuhnya mampu memberikan solusi dan penyelesaian kasus.
\end{abstract}

Kata Kunci: Kekerasan, Nusyuz, Hukum Keluarga

* Diterima tanggal naskah diterima: 13 Desember 2016, direvisi: 24 Maret 2017, disetujui untuk terbit: 22 April 2017.

1 Penulis adalah Dosen bidang Ilmu Hukum pada Fakultas Syariah dan Hukum, Universitas Islam Negeri (UIN) Syarif Hidayatullah Jakarta. Jl. Ir. H. Juanda No. 95 Ciputat Tangsel. E-mail: fitriyani.zein@uinjkt.ac.id. 


\section{Pendahuluan}

Dalam sejarah perkembangan hukum keluarga di periode moderen, terjadi pembaharuan hukum keluarga (perkawinan, perceraian, dan warisan) di sejumlah negara muslim. Sampai tahun 2006 di negara timur tengah misalnya hanya lima Negara yang belum memperbaharui hukum keluarga, bahkan negara-negara ini pun sedang dalam proses pembuatan draft, yakni Emirat Arab, Saudi Arabia, Qatar, Bahrain dan Oman.

Tujuan usaha pembaharuan hukum keluarga berbeda antara satu negara dengan negara lain, yang secara umum dapat dikelompokkan menjadi tiga kelompok. Pertama, negara yang bertujuan untuk unifikasi hukum keluarga. Alasan pembaharuan untuk unifikasi ini adalah karena adanya sejumlah mazhab yang diikuti di negara bersangkutan yang boleh jadi terdiri dari mazhab masih dikalangan sunni, namun juga boleh juga antara sunni dan syi'i. kedua, untuk pengangkatan status wanita. Undang-undang perkawinan Mesir dan Indonesia masuk dalam kelompok ini. Ketiga, untuk merespon perkembangan dan tuntutan zaman karena konsep fiqih tradisional dianggap kurang mampu menjawabnya.

Di Indonesia, undang-undang pertama tentang perkawinan dan perceraian, yang sekaligus dikelompokkan sebagai usaha pembaharuan pertama adalah dengan diperkenalkannya UU No. 22 Tahun 1946. Undang-undang ini hanya berlaku untuk wilayah pulau jawa yang kemudian Undang-Undang pertama tentang perkawinan yang lahir setelah Indonesia merdeka ini diperluas wilayah berlakunya untuk seluruh Indonesia dengan Undang-Undang No. 32 Tahun 1954, yakni undang-undang tentang Pencatatan Nikah, Talak dan Rujuk. Keberadaan Undang-Undang No. 22 Tahun 1946 ini adalah sebagai kelanjutan dari stbl. No. 198 tahun 1895.

Undang-Undang No. 22 Tahun 1946 ini diikuti dengan lahirnya UndangUndang No. 1 tahun 1974 yang berlaku secara efektif sejak tanggal 1 Oktober 1975 ini adalah undang-undang pertama yang mencakup seluruh unsur dalam perkawinan dan perceraian. Undang-Undang ini terdiri dari 14 Bab dan 67 pasal.

\section{PEMBAHASAN}

\section{A. Kekerasan dalam Rumah Tangga}

\section{Kasus Turki}

Turki merupakan negara yang mayoritas penduduknya beragama Islam. Turki mengproklamirkan sebagai suatu negara sejak tahun 1924. Secara Geografis Negara Turki memiliki wilayah yang membentang di dua benua, yaitu benua Eropa dan benua Asia dengan luas wilayah $780576 \mathrm{Km}^{2}$ yang terdiri dari 67 propinsi. 
Berdasarkan hasil sensus tahun 1989 jumlah penduduknya sekitar 55.400 .000 jiwa dengan tingkat kepadatan penduduk 711 jiwa/km2 dan prosentasi tempat tinggal 53\% hidup di perkotaan. Dalam berbangsa dan bernegara mereka memiliki motto yaitu "Yurta Sulh, Cihandra Sulh" (Peace at home, Peace in the world). Turki bukanlah negara agama, meskipun penduduknya $98 \%$ beragam Islam dan $2 \%$ lagi beragama Yahudi, Katolik Roma dan pengikut beberapa kelompok Ortodok timur. Negara menjamin kebebasan beragama bagi penduduknya.

Islam yang berkembang di Turki menganut paham mazhab Hanafi seperti dikatakan Tahir Mahmood;

"In the republic of Turky, Islam is the religion of an over whelming majority. The Hanafi school of Islami law was traditionally followed there till 1926. An Islamic civil code based on the hanafi law (Called the majallat al Ahkamal Adliya).

Turki telah memberikan peluang sebagian Hukum Islam telah menjadi Undang undang Sipil Islam. Ini merupakan respon terhadap perkembangan pemikiran dan politik di Turki. ${ }^{2}$

Pada tahun 1839 dikeluarkan Dekrit imperium - Hatt-i syarif sebagai pondasi bagi rezim legislatif modern. Kemudian pada tahun 1850-1858 dikeluarkan undang-undang perdagangan dan pidana, yang sebagian rumusannya diambil dari hukum mazhab Hanafidan hukum perancis. Kodifikasi dilakukan bersamaan dengan gelombang modernisasi hukum dan westernisasi, seperti penetapan Majallat al Ahkami Al Adliyah. Undang-undang al Ahkam al Adliyah adalah undang-undang sipil pertama yang ditetapkan di dunia Islam. ${ }^{3}$

Pada tahun 1915 kekaisaran mengeluarkan dua keputusan yang mereformasi hukum mazhab Hanafi tentang hak perempuan untuk bercerai di pengadilan. Perempuan dimungkinkan untuk meminta cerai peradilan (faskh) dengan alasan ditinggalkan oleh suami dan penyakit yang diderita suami. Dua tahun kemudian, hukum pernikahan dikodifikasikan, berjudul Qanun -i Qarar Haquq a'ailah al-uthmaniah- hukum Utsmaniyah diberlakukan oleh governmanent kekaisaran. ${ }^{4}$

Di bawah pemerintahan Mustafa Kemal Pasha usaha kodifikasi kembali dilakukan. Hasilnya pada tahun 1924 konstitusi nasional baru ditetapkan dengan mengadopsi sistem hukum sipil. Adopsi tersebut karena perbedaan internal ahli ahli hukum agama telah gagal mengusahakan undang-undang didasarkan hukum Syariah. Undang-undang sipil Turki 1926 yang baru, memuat tentang

2 Tahir Mahmood, Family Law Reform in The Muslim World, N.M. Tripathi PVT. LTD, Bombay, 1972, h.15.

3 Ibid., h.35.

4 Tahir Mahmood, Perdonal Law in Islamic Countries (History, Text and Coparative Analysis) Academy of law and Religion, New delhi, 1987 h.264. 
perkawinan, perceraikan, hubungan keluarga dan kewarisan. Pembaruan perundang undangan terus dilakukan UU sipil 1926 kemudian dilakukan amandemen sebanyak 6 kali. Pemerintah Turki melakukan pembaruan pengaturan hukum Sipil sesuai perkembangan sosial dan politik masyarakatnya hingga sekarang.

Hukum yang berkaitan dengan pernikahan, keluarga dan suksesi incoporading dalam kode sipil tahun 1926 diubah dengan undang-undang sebagai berikut;

1) Kode Sipil (amandemen Pertama) hukum 1933.

2) Kode Sipil (amandeman kedua) hukum tahun 1938.

3) Hukum perdata hukum tahun 1945.

4) Kode Sipil (amandemen) undang undang tahun 1950.

5) Kode Sipil (amademan) undang undang tahun 1933.

6) Kode Sipil tahun 1965.

Terkait dengan masalah kekerasan dalam rumah tangga dalam aturan di Negara Turki diatur dalam pasal 22 yaitu bahwa Pengadilan boleh menetapkan sejumlah uang ganti rugi kepada suami yang menyakiti istri dan yang tidak memenuhi hak nafkah kepada istri.

Menurut UU Sipil Turki ada 6 hal yang membolehkan suami isteri menuntut pengadilan mengeluarkan dekrit perceraian, dengan catatan meskipun dekrit perceraian telah diterbitkan, pengadilan boleh memberikan pemilahan yudisial jika rekonlisiasi diantara pasangan memungkinkan. Jika pemilahan diberikan dan tidak ada rekonsiliasi yang terjadi diantara keduanya sampai akhir periode yang diberikan, salah satu pihak boleh meminta cerai. Keenam hal tersebut adalah:

- Salah satu pihak telah memutuskan

- Salah satu pihak menyebabkan luka bagi pihak lain

- Salah satu pihak telah melakukan tindak criminal yang membuat hubungan perkawianan tidak bisa ditolelir untuk dilanjutkan.

- Salah satu pihak telah pindah rumah dengan cara yang tidak etis atau tanpa ada sebab yang jelas selama sekurang-kurangnya 3 bulan

- Salah satu pihak menderita penyakit mental yang membuat hubungan perkawinan tidak bisa ditolelir, yang dinyatakan dengan keterangan dokter dalam periode sekurang-kurangnya 3 tahun

- Hubungan suami dan isteri sedemikian tegang sehingga hubungan perkawinan tidak bisa ditolelir. ${ }^{5}$

${ }^{5}$ https://aafandia.wordpress.com/2009/05/20/hukum-islam-di-negara-turki/ 


\section{Kasus Yordan}

Yordania merupakan salah satu kerajaan yang terletak di Asia Barat. Penduduknya mayoritas beragama Islam. Sebanyak 95\% di antaranya beraliran Sunni dan bermazhab Hanafi. Selainnya, 4\% Kristen dan 1\% lagi adalah gabungan Druze dan Baha'i. Negara Modern Yordania pertama kali muncul pada tahun 1921 sebagai Emiran Transyordan. Semenjak runtuhnya dinasti Utsmani, Yordania berada di bawah kekuasaan Inggris dan memperoleh kemerdekaannya pada tahun 1946 yang selanjutnya menjadi kerajaan Hasyimiyah Yordania. Mayoritas penduduk Yordania pada permulaan abad 20 adalah petani dan pedagang yang tinggal di pedesaan. Umumnya mereka adalah penganut mazhab Hanafi.

Sampai tahun 1951, Yordania masih memberlakukan hukum keluarga Turki Usmani sampai diundangkannya undang-undang hak-hak keluarga no. 92 tahun 1951. Undang-undang ini mengatur tentang perkawinan, perceraian, mahar, pemenuhan nafkah bagi isteri dan keluarga, dan tentang pemeliharaan anak. Undang-undang ini sekaligus mencabut ketentuan-ketentuan yang terdapat pada hukum keluarga Turki Usmani.

Pada perkembangan selanjutnya, undang-undang hak-hak keluarga tahun 1951 diganti dengan undang-undang status personal Yordan 1976 (undang-undang No. 61 tahun 1976) yang disebut dengan qanun al-ahkhwal alsyakhsiyah. Undang-undang ini didominasi oleh paham mazhab Hanafi sebagai hukum tidak tertulis yang masih tetap berlaku. Amandemen berikutnya dilakukan pada tahun 1977 yang menghasilkan undang-undang no. 25 tahun 1977.6

Selain itu, dalam hal kekerasan dalam rumah tangga tidak secara explisit menerangkan masalah ini hanya saja undang-udang No. 25 tahun 1977 juga mengatur kewenangan isteri untuk meminta cerai. Dalam pasal 114, 116, 123, dan 130 dijelaskan bahwa isteri memiliki kewenangan untuk meminta cerai dalam kondisi antara lain;

1) Apabila suami menderita impotensi dan sakit yang dapat membahayakan isteri apabila mereka hidup bersama. Namun jika penyakit yang diderita suami (selain impotensi) sudah diketahui isteri sebelum perkawinan, maka isteri tidak punya hak meminta perceraian. Dalam hal penyakit kelamin atau lepra, harus ada pendapat ahli kedokteran. Bila dimungkinkan untuk disembuhkan, maka ditunda selama setahun untuk memberi kesempatan penyembuhan.

2) Suami meninggalkan isteri dalam jangka waktu satu tahun atau lebih tanpa alasan yang jelas, meskipun suami meninggalkan nafkah untuknya.

${ }^{6}$ http://sarmidihusna.blogspot.com/2008/11/hukum-keluarga-di-yordania.html 
3) Suami divonis penjara selama tiga tahun, meski ia mempunyai harta yang cukup untuk menafkahi isterinya selama ia menjalani hukuman. Perkawinan bisa dibubarkan setahun setelah vonis dijatuhkan.

\section{Kasus Sudan}

Peraturan tentang perkawinan dan perceraian di Sudan diatur dalam bentuk ketetapan-ketetapan hakim (Manshurat al-Qadi al-Quda) yang terpisahpisah, yaitu: (1) UU Tentang Nafkah dan Perceraian dalam Manshur No. 17 Tahun 1916; (2) UU Tentang Orang Hilang dalam Manshur No. 24 Tahun 1921; (3) UU tentang Warisan dalam Manshur No. 26 Tahun 1925; (4) UU tentang Nafkah dan Perceraian dalam Manshur 28 Tahun 1927; (5) UU tentang Pemeliharaan Anak dalam Manshur 34 Tahun 1932; (6) UU tentang Talak, Masalah Rumah Tangga (syiqaq dan Nusyuz) dan Hibah dalam Manshur 41 Tahun 1935; (7) UU tentang Perwalian Harta Kekayaan dalam Manshur No. 48 Tahun 1937; (8) UU tentang Warisan dalam Manshur No. 51 Tahun 1943, sekaligus memperbarui Manshur No. 49 Tahun 1939; (9) UU tentang Wasiat dalam Manshur No. 53 Tahun 1945; (10) UU tentang Wali Nikah dalam Manshur No. 54 Tahun 1960, sekaligus memperbarui Manshur No. 35 Tahun 1933.

\section{Kasus Malaysia}

Menurut penelitian, angka tindak pidana kekerasan terhadap perempuan dalam rumah tangga mencapai 21.343 kasus di antara tahun 2000 sampai dengan 2006. Data diambil data resmi Police Diraja Malaysia dalam Women Center for change di Penang Malaysia. ${ }^{7}$

\section{Kasus di Indonesia.}

Kekerasan dalam Perkawinan atau yang lebih dikenal dengan Kekerasan dalam Rumah Tangga (KDRT) terjadi dalam jumlah sangat besar. KDRT tidak hanya terjadi pada Istri, tetapi juga terjadi pada suami dan anal-anak. Mengingat angka tindak KDRT di Indonesia cukup tinggi maka hal terkait dengan masalah KDRT diatur dalam Undang-Undang tersendiri yaitu UU Nomor 23 Tahun 2004 tentang Penghapusan Kekerasan dalam Rumah Tangga.

Dalam UU tersebut dijelaskan dan ditegaskan definisi KDRT, batasan KDRT, bentuk-bentuk KDRT berikut sanksi hukumnya, baik berupa sanksi pidana (Penjara) hingga ganti rugi. KDRT bukan saja berupa kekerasan fisik yang diatur dalam UU tersebut, ada bentuk KDRT lain seperti penelantaran anak

${ }^{7}$ http://law.uii.ac.id/tag/perbandingan-hukum-pidana-kdrt-indonesia-danmalaysia 
dan istri dimasukkan ke dalam kategori KDRT. Dalam UU ini delik pidana KDRT dimasukkan ke dalam delik aduan.

\section{B. Nusyus Dalam Hukum Keluarga Islam di Negara Muslim}

\section{Kasus Indonesia}

Sejarah pengesahan UU Nomor 1/1974 tentang Perkawinan mencatat bahwa terkait batas usia dalam Draft RUU tersebut pada Pasal 7 ayat (1) Rancangan Undang-Undang Perkawinan Tahun 1973. Dalam RUU tersebut dinyatakan batas minimal usia kawin adalah 21 tahun bagi laki-laki dan 18 tahun bagi perempuan. Namun demikian, karena RUU ini menuai perdebatan yang rawan dengan konflik, akhirnya pembahasan mengenai hal ini ditunda. Gejolak dan potensi konflik berakhir setelah diresmikan Undang-Undang Nomor 1 Tahun 1974 tentang Perkawinan. ${ }^{8}$

Standar usia minimal kawin sebagaimana tercantum pada Pasal 7 ayat (1), pada akhirnya diturunkan dari 21 tahun menjadi 19 tahun bagi laki-laki. Negara menetapkan peraturan perkawinan hanya diizinkan jika pihak pria sudah mencapai umur 19 tahun dan pihak wanita sudah mencapai umur 16 tahun. Jika terdapat penyimpangan di bawah ketentuan, maka masyarakat berhak mengajukan dispensasi kepada pengadilan atau pejabat lain yang berkepentingan. Artinya, ketentuan usia minimal kawin dalam RUU Perkawinan 1973 diubah oleh Undang-Undang Perkawinan yang disahkan Tahun 1974.

Ada beberapa penyebab dari peristiwa (perubahan standar) ini sebagaimana dikemukakan oleh Ratno Lukito. Pertama, belum terselesaikannya kajian teoretis tentang usia dewasa antara umat Islam dan negara yang mengatur usia minimal kawin dengan praktik perkawinan pada waktu itu. Kedua, kecenderungan masyarakat dalam praktik perkawinan masih berkutat pada pemahaman fikih atau budaya setempat. Ketiga, kondisi relasi gender tradisional masih melekat kuat dalam masyarakat, sehingga menyulitkan negara dalam menerapkan batas usia minimal kawin sesuai cita-cita awal RUU Perkawinan. Dengan kata lain, persoalan penentuan usia minimal kawin lebih kepada soal perdebatan paradigma hukum antara tradisi Islam dan negara. ${ }^{9}$

Mark E. Cammack berpandangan bahwa pengaturan usia minimal kawin lebih merupakan bagian dari tujuan Pemerintah untuk mengurangi problemproblem perkawinan seperti pernikahan di bawah umur. Tujuan selanjutnya adalah untuk proyek unifikasi hukum perkawinan agar sesuai dengan program

${ }^{8}$ Euis Nurlaelawati, The Kompilasi Hukum Islam and Legal Practice in the Indonesian Religious Courts: Modernization, Tradition, and Identity (Amsterdam: International Convention of Asia Scholars (ICAS), Amsterdam University Press, 2010), h.16.

${ }^{9}$ Ratno Lukito, Hukum Sakral dan Hukum Sekuler: Studi tentang Konflik dan Resolusi dalam Sistem Hukum Indonesia (Jakarta: Pustaka Alvabet, 2008), h.264. 
persatuan Indonesia berlandaskan Pancasila dan memenuhi tuntutan kemodernan sebagaimana yang telah terjadi di negara-negara lain. Menurut Penulis, kondisi pergulatan antara umat Islam dan negara tersebut pada dasarnya dipicu oleh ketidakpuasan umat Islam atas dominasi Pemerintah pusat untuk menyeragamkan masalah praktik perkawinan. Saat itu banyak kalangan umat Islam tidak setuju dengan beberapa isi pasal dalam RUU Perkawinan 1973. Mereka menilai terdapat beberapa hal tidak sesuai dengan hukum Islam. Meski demikian, Pemerintah, melalui DPR, pada Januari 1974, tetap mengesahkan RUUP 1973, tetapi dengan beberapa perubahan di dalamnya, termasuk masalah batas minimal usia kawin dari yang sebelumnya 21 tahun bagi laki dan 18 tahun bagi perempuan36 menjadi 19 tahun bagi laki-laki dan 16 tahun untuk perempuan. Oleh sebagian pengamat, hal ini dinilai merupakan salah satu keberhasilan Pemerintah dalam mereformasi hukum perkawinan di Indonesia sehingga akan berdampak baik pada tata hukum perkawinan nasional ke depannya.

Komplikasi Hukum Islam pada Bab IV Pasal 15 mempertegas persyaratan yang terdapat dalam Undang-Undang perkawinan dengan rumusan sebagai berikut:

1) Untuk kemashlahatan keluarga dan rumah tangga, perkawinan hanya boleh dilakukan calon mempelai yang telah mencpaai umur yang ditetapkan dalam pasal 7 Undang-undang No. 1 tahun 1974 yakni calon suami sekurang-kurangnya berumur 19 tahun dan calon istri sekurangkurangnya berumur 16 tahun

2) Bagi calon mempelai yang belum mencapai umur 21 tahun harus mendapat izin sebagaimana yang diatur dalam pasal 6 ayat (2), (3), (4) dan (5) UU No. 1 Tahun 1974.

\section{Nusyuz dalam Kompilasi Hukum Islam}

Dalam Kompilasi Hukum Islam, soal Nusyuz juga diatur. Beberapa pasal menegaskan hak dan kewajiban suami dan istri.

\section{Pasal 80}

1) Suami adalah pembimbing terhadap isteri dan rumah tangganya, akan tetapi mengenai hal-hal urusan rumah tangga yang penting-penting diputuskan oleh suami dan isteri.

2) Suami wajib melindungi isterinya dan memberikan segala sesuatu keperluan hidup beruma tangga sesuai dengan kemampuannya.

3) Suami wajib memberi pendidikan agama kepada isterinya dan memberi kesempatan belajar pengetahuan yang berguna dan bermanfaat bagi agama, nusa dan bangsa.

4) Sesuai dengan pengahsilannya suami menanggung: 
a. Nafkah, kiswah dan tempat kediaman isteri;

b. Biaya rumah tangga, biaya perawatan dan biaya pengobatan bagi isteri dan anak;

c. Biaya pendidikan bagi anak.

\section{Pasal 83}

1) Kewajiban utama bagi seorang isteri adalah berbakti lahir dan batin kepada suami di dalam batas-batas yang dibenarkan oleh hukum Islam;

2) Isteri menyelenggarakan dan mengatur keperluan rumah tangga dengan sebaik-baiknya;

\section{Pasal 84}

1) Isteri dapat dianggap nusyuz jika ia tidak melaksanakan kewajibankewajiban sebagaimana dimaksud dalam pasal 83 ayat (1) kecuali dengan alasan yang sah.

2) Selama isteri dalam nusyuz, kewajiban suami terhadap isteriya tersebut pasal 80 ayat (4) huruf a dan b tidak berlaku kecuali hal-hal untuk kepentingan anaknya.

3) Kewajiban suami tersebut pada ayat (2) diatas berlaku kembali setelah isteri tidak nusyuz.

4) Ketentuan tentang ada atau tidaknya nusyuz dari isteri harus didasarkan atas bukti yang sah.

\section{Kasus Malaysia}

Melalui penelitian terhadap Hukum Keluarga Islam Perak 2004, Nusyuz hanya terdapat dalam Bagian VI, yaitu Nafkah Isteri, Anak dan Lain-lain di bawah perkara Kuasa Mahkamah untuk Memerintahkan Nafkah bagi Isteri yang terkesan Nusyuz, yaitu Pasal 60 (2) dan 60 (3). Kandungan kedua-dua seksyen tersebut adalah seperti berikut: Amir Fariz bin Che Man, et al. / Pensabitan Nusyuz Isteri di Mahkamah Rendah Syariah Ipoh Perak 3260.

(2) Terdapat kepada Hukum Syarah dan pengesahan Mahkamah, seseorang isteri tidaklah berhak mendapat nafkah apabila dia nusyuz atau tidak patuh menurut perintah sah suaminya, yaitu antara lain; a) apabila dia menjauhkan dirinya daripada suaminya; b) apabila dia meninggalkan rumah suaminya bertentangan dengan kemauan suaminya; atau c) apabila dia enggan berpindah bersama suaminya ke suatu rumah atau tempat lain, tanpa apa-apa sebab yang sah mengikut Hukum Syara'. 
(3) jika isteri itu bertaubat dan menurut atas kemauan perintah sah suaminya, maka isteri itu tidaklah lagi menjadi nusyuz. ${ }^{10}$

Dalam penelitian tersebut nusyuz tidak disebut secara jelas yang khusus dalam aturan Hukum Keluarga Islam Perak 2004. Sebaliknya, persoalan nusyuz hanya disebut di bawah perkara berkait dalam Journal of Human Development and Communication Volume 3 (Special Issue), 2014 [27-46] yang telah dikemukakan dalam seminar sebelumnya. Proseding berkaitan nusyuz ini perlu melalui hukum dan bukannya melalui permohonan kerena Hukum Tatacara Mal Mahkamah Syariah Perak 2004 telah menetapkan sedemikian. Dengan merujuk kandungan Pasal 63 hingga 67 Enakmen Tatacara Mal Mahkamah Syariah Perak 2004 ini, dapatlah disimpulkan bahwa dalam konteks kasus nusyuz, beberapa tindakan perlu dilaksanakan oleh pihak yang berperkara sebelum pihak mahkamah memutuskan atau mensabitkan seseorang isteri telah melakukan nusyuz sekaligus menggugurkan hak nafkahnya. Tindakan-tindakan tersebut secara umumnya apabila seseorang suami itu ingin membuat tuntutan atas nusyuz ke atas isterinya, pihak suami perlu membuktikan pernyataan tuntutan kepada mahkamah. Dalam tuntutan tersebut, pihak suami selaku perlu menyatakan dan memberikan fakta-fakta yang dijadikan dasar dan yang menunjukkan bukti-bukti tindakan istrinya termasuk butiran-butiran tertentu yang menyokong dakwaan tersebut benar adanya. Selain itu, dalam tuntutan itu juga pihak suami perlu memasukkan suatu pernyataan tentang tuntutan, yaitu memohon mahkamah memutuskan nusyuz keatas isterinya berdasarkan peruntukan yang berkaitan dalam Hukum Keluarga Islam Perak 2004. Apabila pihak mahkamah telah mendaftarkan kasus tersebut, maka pihak mahkamah akan memanggil kedua belah pihak, yaitu suami dan isteri untuk mendengar keterangan kedua pihak. Sekiranya pihak isteri mengakui dan tidak menafikan terhadap segala yang terkandung dalam tuntutan yang dibuat oleh suaminya dan mahkamah menerima dengan fakta-fakta serta bukti-bukti yang menyokong tuntutan suami, maka mahkamah akan memutuskan nusyuz ke atas isteri tersebut berdasarkan pasal 60 (2) Hukum Keluarga Islam Perak 2004.

Namun, jika isteri selaku tergugat itu tidak mengakui hal tersebut dengan sebagian atau keseluruhan kandungan tuntutan yang dibuat oleh pihak suaminya, maka pihak isteri boleh memberikan pernyataan pembelaan. Dalam pembelaan tersebut, pihak isteri perlu memasukkan pernyataan yang mengaku atau menafikan setiap fakta dan butiran yang terkandung dalam pernyataan tuntutan pihak suami. Pihak isteri juga perlu menyatakan fakta-fakta baru yang dijadikan dasar olehnya sebagai pembelaan. Bagi menguatkan pembelaan tersebut, pihak isteri perlu mengungkapkan apa-apa perkara perundangan yang berkaitan. Amir Fariz bin Che Man, et al. mengungkapkan Nusyuz Isteri di Mahkamah Rendah Syariah Ipoh Perak 34 Selain pembelaan, pihak mahkamah

${ }_{10}$ Amir Fariz bin Che Man., “Pentasbitan Nusyuz Istri di Mahkamah Rendah Syari'ah Ipoh"., Journal of Human Development and Communacation Vol. 3 (Special Issue), 2014 (27-46). 
juga memberi peluang kepada pihak isteri untuk mengemukakan tuntutan balik jika ada, bersama-sama dengan pembelaannya itu. Setelah pihak isteri menyatakan pembelaannya dan tuntutan balas gugatan, mahkamah boleh (atas alasan yang mencukupi) memberi kebenaran kepada pihak tergugat untuk membuktikan suatu jawaban kepada pembelaan. Apabila semua proses ini telah dilalui, mahkamah akan meneliti sedalam dalamnya atas segala keterangan, bukti dan butiran fakta yang ada. Setelah mengumpulkan bukti yang ada, maka keputusan untuk memutuskan nusyuz atas seseorang isteri itu pun dibuat. Bagi tuntutan nusyuz yang dibuktikan dengan alasan isteri meninggalkan rumah tanpa izin atau isteri enggan mentaati suami, pihak mahkamah terlebih dahulu akan mengeluarkan perintah kembali taat dalam sesuatu masa yang sesuai kepada pihak isteri. Jika masa yang diberikan oleh pihak mahkamah telah berakhir tetapi pihak isteri masih tidak menuruti perintah mahkamah itu, maka barulah mahkamah memutuskan atau mensabitkan isteri itu nusyuz. Sebenarnya berdasarkan Hukum Keluarga Islam Perak 2004, perintah untuk isteri kembali taat kepada suami tidak dijelaskan. Walau bagaimanapun, dari segi amalan di Mahkamah Rendah Syariah Ipoh Perak, kebiasaannya hakim akan menggunakan dengan cara mengeluarkan perintah kembali taat kepada pihak isteri terlebih dahulu sebelum keputusan memutuskan nusyuz dibuat.

\section{Kasus Sudan}

Sudan adalah Negara majemuk yang terdiri atas berbagai macam kebudayaan dan etnis, menghormati dan mengahargai agama-agama yang ada. Wilayah Sudan terletak di benua Afrika yang berbatasan dengan mesir dan lybia di utara, chad republic Afrika tengah dan Zaire di barat, Ethiopia dan tengara serta Uganda dan Kenya. Selain itu sudan merupakan Negara kesatuan yang kekuasaannya memberlakukan hukum Islam sebagai asas perundang-undangan dalam kesatuan dan persatuan.

Dalam menjalankan pengembangan hukum, sudan memiliki lembaga peradilan yang mempunyai kebebasan dann berdiri sendiri tanpa dapat diintervensi oleh kekuasaan. Sekalipun demikian lembaga ini bertanggung jawab penuh kepada kepala Negara dalam pelaksanaannya, sesuai dengan perundangundangan yang berlaku. Lembaga peradilan ini mempunyai kepala yang disebut rasiul qadha dan langsung dipilih oleh kepala Negara. Lembaga ini mempunyai kewenangan dalam menjalankan perundang-undangannya di antaranya: 1). Menfsirkan teks-teks perundang-undangan; 2). Menjalankan dan memberikan putusan-putusan hukum terhadap pelaku-pelaku kejahatan.

Adapun bentuk lembaga-lembaga peradilan ini terdiri dari lembaga tertinggi, menengah, dan awaliyah. Lembaga peradilan tertinggi mempunyai kewenangan dalam membatasi perundang-undangan dan pembentukannya, lembaga peradilan menengah dan lembaga peradilan awaliyah memiliki 
kewenangan dalam memberikan keputusan terhadap pelaku tindak kejahatan, permasalahan al-ahwal asy-syaksiyah, seperti perkawinan, zakat, infak, dan waris. $^{11}$

Hukum keluarga merupakan hukum yang hidup dan mengakar di masyarakat, dan menempati posisi yang signifikan sebagai kekuatan moral masyarakat (moral force of people). Modernisasi hukum keluarga Islam menjadi fenomena unik yang terjadi di dunia Muslim modern. Hukum keluarga bersifat adaptif dan aplikatif terhadap perkembangan yang berbeda antar negara. Di Sudan, pembaharuan hukum telah banyak dilakukan, aturan hukum yang dibuat berdasarkan hasil keputusan Hakim (Qadhi al-Qudhat) yang kemudian dibukukan dalam bentuk Manshurat: diambil tidak hanya dari satu mazhab namun men-talfiq dari berbagai mazhab. Produk hukum keluarga Sudan mengarah kepada kebijakan reformasi melalui keputusan hakim (the expedient of reform by judicial decisions). ${ }^{12}$

Negara inilah yang sampai saat ini belum memiliki Kodifikasi UU keluarga. Aturan perkawinan dan perceraian di tetapkan berdasarkan ketetapanketetapan hakim (Manshurot Al-Qodi wal-Qudo). Diantaranya adalah:

a. Aturan nafkah dan perceraian diatur dalam manshur 17 tahun 1916,

b. Aturan nafkah dan perceraian diatur dalam manshur 28 tahun 1927,

c. Aturan tentang pemeliharaan anak pada manshur 28 tahun 1927,

d. Aturan tentang thalaq, shiqaq dan wasiat diatur dalam manshur 41 tahun 1935

e. Aturan tentang wali nikah dalam manshur 54 tahun 1960.

Dalam kasus Nuszus terdapat pada UU thalaq dalam rumah tangga (terdapat didalamnya shiqaq dan Nusuz) yaitu di dalam Manshur No 41 tahun 1935.

\section{Turki}

Dalam The Turkish Family Law of Cyprus tahun 1951 pasal 22: menetapkan bahwasanya pengadilan boleh menetapkan uang ganti rugi yang harus dibayar dari istri yang tidak memenuhi kewajibannya. Dan hak nafkah istri gugur dengan sendirinya.

\section{Analisis Horisontal, Vertikal, dan Diagonal}

a. Analisis Horisontal

\footnotetext{
${ }^{11}$ https://kajianfahmilquranhfd.wordpress.com/2013/08/02/perkembangan-hukum-islampada-masa-modern-yaitu-di-mesir-sudan-dan-maroko/

${ }^{12}$ Qodir Zaelani Qodir Zaelani., Pembaruan Hukum Keluarga: Kajian atas Sudan Indonesia., h. 1
} 
Secara umum Kelima Negara sama-sama memberikan perhatian dalam masalah kekerasan dalam rumah tangga melalui ketentuan yang terkait dengan thalaq, khususnya ketentuan tentang kebolehan seorang Isteri mengajukan gugatan cerai ke pengadilan. Kebolehan tentang gugat cerai isteri menjadi salah jalan keluar dari kemelut yang terjadi dalam rumah tangga, khususnya jika terjadi kekerasan yang dilakukan salah satu pihak.

Perbedaannya terletak pada sanksi hukum jika terjadi kekerasan dalam rumah tangga, apakah cukup dengan memberikan hak gugat thalak semata atau ada sanksi hukum lain terhadap tindak kekerasan dalam rumah tangga? dalam masalah ini ketentuan hukum keluarga di Turki dan Indonesia lebih maju dari keempat negara muslim lainnya. Di Negara Turki diatur dalam pasal 22 yaitu bahwa Pengadilan boleh menetapkan sejumlah uang ganti rugi kepada suami yang menyakiti istri dan yang tidak memenuhi hak nafkah kepada istri. Di Indonesia pelaku kekerasan dalam perkawinan diatur secara tersendiri dalam Undang-Undang Nomor 23 Tahun 2004 tentang Peghapusan Kekerasan dalam Rumah Tangga (KDRT). Dalam UU ini diatur dengan sangat tegas berbagai bentuk KDRT dan sanki hukum bagi pelakunya berupa penjara dan ganti rugi/denda.

Di Malaysia, Sudan dan Yordania tidak ditemukan ketentuan khusus terkait dengan Kekerasan dalam Perkawinan. Di Sudan dan Yordan tidak ditemukan ketentuan eksplisit tentang KDRT kecuali pasal yang membolehkan gugat cerai istri dikarenakan tersakiti oleh suami. Di Malaysia, meski ditemukan data yang cukup memprihatinkan tentang tindak KDRT tetapi hanya satu Negara bagian yang mengatur hal tersebut.

Sementara itu, terkait dengan masalah Nusyuz kelima Negara di atas memiliki aturan tentang masalah nusyuz. Turki mengatur sanksi bagi istri yang nusyuz berupa kebolehan tidak diberikan nafkah hingga ganti rugi bagi istri yang nusyus. Sama dengan di Indonesia yang membolehkan suami untuk tidak memberikan nafkah bagi Istri yang nusyuz hanya saja tidak ada aturan tentan ganti rugi. Di Malaysia ketentuan nusyuz diatur cukup detail berupa berbagai bentuk perbuatan yang termasuk dalam kategori nusyuz, sama seperti di Indonesia tetapi Malaysia lebih eksplisit dan rinci. Sementara Sudan dan Yordan mengatur masalah nusyuz secara general saja.

\section{b. Analisis Vertical}

Persoalan Kekerasan dalam Perkawinan menjadi polemic yang berkepanjangan dalam diskursus pemikiran hukum Islam. Pasalnya di Islam, suami sebagai kepala rumah tangga berkewajiban memimpin, menjaga dan melindungi keluarga. Dalam konteks itu suami wajib mendidik, menasehati dan meluruskan istri dan anak-anak. Sebaliknya istri wajib patuh, taat dan mengabdi kepada Istri. Dalam hal kewajiban suami tersebut di dalam nash Alquran surah an-Nisaa: 34 dibolehkan suami melakukan 3 hal sebagaimana firman-Nya: 
“Wanita-Wanita yang kamu khawatirkan nusyuznya maka nasehatilah mereka dan pisahkanlah mereka di tempat tidur mereka dan pukullah mereka. Kemudian jika mereka mentaatimu makan janganlah kamu mencari-cari jalan menyusahkannya. Sesungguhnya Allah Maha Tinggi dan Maha Besar."

Ayat di atas seolah-olah melegitimasi kebolehan seorang suami memukul istri, padahal ketentuan ayat tersebut secara tegas hanya dalam konteks ta'dib dan tarbiyah istri, jika berbuat nusyus dengan tiga tahapan dan diakhir ayat ditegaskan bahwa tidak boleh membuat kesusahan istri apalagi mencari-cari jalan menyusahkannya. Terlebih lagi dalam ayat-ayat lain diperintahkan untuk bermu'asyarah bil ma'ruf, demikian juga dalam banyak hadits banyak ditegaskan larangan menyakiti Istri seperti contoh hadits di bawah ini:

"Berbuat baiklah pada wanita karena wanita diciptakan dari tulang rusuk dimana tulang rusuk bagian atasnya bengkok. Jika kamu mencoba meluruskannya (dengan keras) maka engkau akan mematahkannya dan jika kamu membiarkannya maka ia akan tetap bengkok. Maka berbuat baiklah kepada para wanita". (HR Imam Bukhori dan Imam Muslim)

Dalam hadits lain dijelaskan bahwa kebolehan memukul tidak boleh dilakukan pada wajah.

Dengan demikian, substansi ajaran Islam melarang keras tindak kekerasan dalam rumah tangga. Apalagi jika kekerasan tersebut mengakibatkan cacat atau kematian maka bagi pelakunya tetap diberlakukan jarimah hudud atau ta'zir. Negara boleh membuatu ketentuan hukum ta'zir bagi pelaku KDRT.

Persoalannya dalam ketentuan UU KDRT di Indonesia, yang termasuk dalam KDRT adalah menyakiti fisik dan psikis. Menjadi sangat subjektif apa yang dimaksud dengan menyakiti psikis? Akan lebih rancu lagi melihat pemikiran dan penafsiran aktivis gender bahwa yang dimaksud KDRT psikis menyakiti jiwa/psikis dalam bentuk kekerasan verbal berupa kata-kata. Sulit dibayangkan kekacauan hukum yang terjadi jika yang dimaksud kekerasan fisik adalah kekerasan verbal dimana dalam kehidupan rumah tangga seringkali terjadi pertengkaran dan adu mulut lalu dikategorikan sebagai KDRT yang dapat diadukan ke pengadilan. Dalam hal sanksi pidana kekerasan fisik sudah jelas didefinisikan bentuk kekerasan fisik yang bagaimana yang dapat diadukan sebagai tindak pidana KDRT.

\section{c. Analisis Diagonal}

Berdasarkan paparan di atas, terlihat perbandingan keberlakuan hukum terkait kekerasan dalam rumah tangga dan nusyuz antara Indonesia dengan Negara-negara muslim lainnya. Di Yordan dan Sudan tidak ada ketentuan yang eksplisit ketentuan tentang perkara kekerasan dalam rumah tangga. Sementara Turki mengatur secara jelas mengenai masalah tersebut dimana istri yang 
mengalami kekerasan dalam rumah tangga dapat melakukan gugatan cerai terhadap suaminya. Selain itu, suami juga dapat dikenakan ganti rugi atas perbuatan kekerasan yang dilakukannya. Di Indonesia KDRT juga dapat dijadikan dasar bagi salah satu pihak mengajukan gugatan cerai dan pelaku KDRT masuk dalam bentuk pelanggaran pidana.

Terkait dengan masalah nusyuz, Turki mengatur masalah ini, dimana seorang wanita yang berbuat nusyuz boleh dihentikan pemberian nafkah kepadanya bahkan dapat dikenakan ganti rugi. Sementara Sudan tidak mengatur masalah secara eksplisit. Di Malaysia, ketentuan terkait nusyuz hanya diatur dalam peraturan di Negara bagian Perak. Peraturan tersebut secara eksplisit menentukan bahwa istri yang melakukan nusyus terhadap suami maka suami berhak untuk tidak memberikan nafkah kepadanya, kecuali jika istri itu bertaubat maka nafkah wajib diberikan kepadanya. Ketentuan tersebut sama persis dengan ketentuan Pasal 84 Kompilasi Hukum Islam di Indonesia, bedanya di dalam Pasal 84 ditekankan bahwa penghentian nafkah hanya kepada isteri tidak kepada anak-anak yang tetap menjadi tanggung jawab suami/orang tua.

\section{Kesimpulan}

Hukum keluarga di dunia Islam memiliki berbagai karakteristik dan distingsi yang berbeda-beda antara satu dengan lainnya. Budaya patriarkhi dan relasi pria-wanita sangat mempengaruhi ketentuan-ketentuan hukum keluarga seperti pada kasus kekerasan dalam perkawinan dan nusyuz. Tampak sekali ketegasan ketentuan hukum dipengaruhi oleh kuat tidaknya budaya patriarkhi di tiap Negara tersebut serta bagaimana kesetaraan relasi pria wanita terjadi.

Di masa yang akan datang dapat diyakini, jika tidak dikatakan dipastikan, bahwa akan terus terjadi pembaharuan-pembaharuan hukum keluarga di negara-negara muslim seiirng semakin terbukanya informasi dan kesadaran akan kesataraan relasi gender namun tetap tidak meninggalkan norma dan substansi ajaran Islam.

\section{Daftar Pustaka}

Aji, Ahmad Mukri. Urgensi Maslahat Mursalah Dalam Dialektika Pemikiran Hukum Islam, Bogor: Pustaka Pena Ilahi, 2012.

http://law.uii.ac.id/tag/perbandingan-hukum-pidana-kdrt-indonesiadanmalaysia

http://sarmidihusna.blogspot.com/2008/11/hukum-keluarga-di-yordania.html https://aafandia.wordpress.com/2009/05/20/hukum-islam-di-negara-turki/ https://kajianfahmilquranhfd.wordpress.com/2013/08/02/perkembangan-hukumislam-pada-masa-modern-yaitu-di-mesir-sudan-dan-maroko/ 
Jamaa, La. "Perlindungan Korban Kekerasan Dalam Rumah Tangga Dalam Hukum Pidana Indonesia," dalam Jurnal Cita Hukum, Vol. 2, No. 2 (2014).

Lukito, Ratno. Hukum Sakral dan Hukum Sekuler: Studi tentang Konflik dan Resolusi dalam Sistem Hukum Indonesia, Jakarta: Pustaka Alvabet, 2008.

Mahmood, Tahir. Family Law Reform in The Muslim World, N.M. Tripathi PVT. LTD, Bombay ,1972.

Mahmood, Tahir. Personal Law in Islamic Countries (history, Text and coparative Analysis) Academy of law and Religion, New delhi, 1987 h.264

Man, Amir Fariz bin Che. "Pentasbitan Nusyuz Istri di Mahkamah Rendah Syari'ah Ipoh", Journal of Human Development and Communacation Vol. 3 (Special Issue), 2014.

Nurlaelawati, Euis. The Kompilasi Hukum Islam and Legal Practice in the Indonesian Religious Courts: Modernization, Tradition, and Identity (Amsterdam: International Convention of Asia Scholars (ICAS), Amsterdam University Press, 2010.

Yunus, Nur Rohim. Restorasi Budaya Hukum Masyarakat Indonesia, Bogor: Jurisprudence Press, 2012.

Zaelani, Qodir Zaelani Qodir. Pembaruan Hukum Keluarga: Kajian atas Sudan Indonesia. 


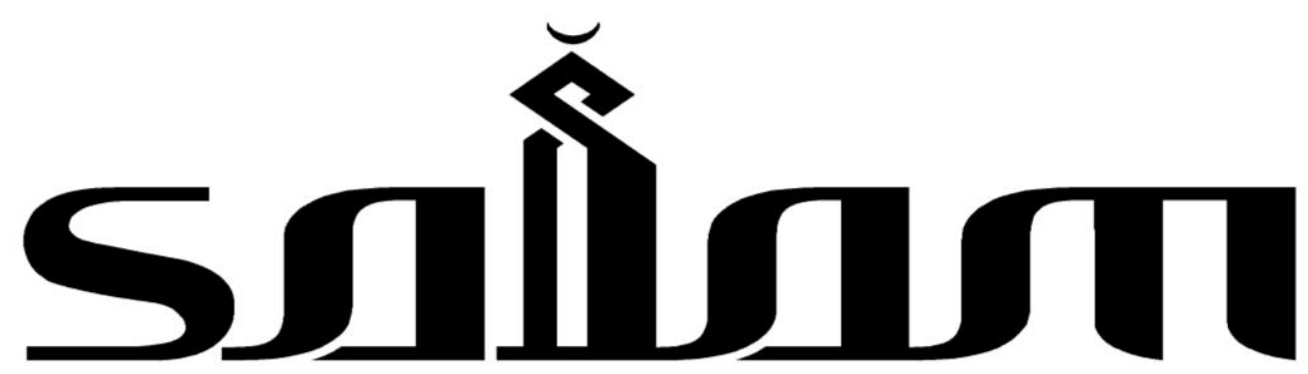

Jumnal Sosial dan Budaya Syar'i

\section{PEDOMAN TEKNIS PENULISAN BERKALA ILMIAH}

1. Artikel adalah benar-benar karya asli penulis, tidak mengandung unsur plagiasi, dan belum pernah dipublikasikan dan/atau sedang dalam proses publikasi pada media lain yang dinyatakan dengan surat pernyataan yang ditandatangani di atas meterai Rp 6000;

2. Naskah dapat berupa konseptual, resume hasil penelitian, atau pemikiran tokoh;

3. Naskah dapat berbahasa Indonesia, Inggris, Arab, maupun bahasa Rusia;

4. Naskah harus memuat informasi keilmuan dalam ranah ilmu hukum Positif;

5. Aturan penulisan adalah sebagai berikut:

a. Judul. Ditulis dengan huruf kapital, maksimum 12 kata diposisikan di tengah (centered);

b. Nama penulis. Ditulis utuh, tanpa gelar, disertai afiliasi kelembagaan dengan alamat lengkap, dan alamat e-mail;

c. Abstrak. Ditulis dalam bahasa Inggris dan Bahasa Indonesia antara 80-120 kata;

d. Sistematika penulisan naskah adalah sebagai berikut:

1) Judul;

2) Nama penulis (tanpa gelar akademik), nama dan alamat afiliasi penulis, dan e-mail;

3) Abstrak ditulis dalam dua bahasa, yaitu bahasa Indonesia dan Inggris, antara 80-120 kata;

4) Kata-kata kunci, antara 2-5 konsep yang mencerminkan substansi artikel;

5) Pendahuluan;

6) Sub judul (sesuai dengan keperluan pembahasan);

7) Penutup; dan

8) Pustaka Acuan (hanya memuat sumber-sumber yang dirujuk dan sedapat mungkin terbitan 10 tahun terakhir).

e. Ukuran kertas yang digunakan adalah kertas HVS 70 gram, ukuran A4, margin: atas $3,5 \mathrm{~cm}$, bawah $3.5 \mathrm{~cm}$, kiri $3,5 \mathrm{~cm}$, dan kanan $3,5 \mathrm{~cm}$;

f. Panjang Naskah antara 13 s.d. 15 halaman, spasi 1, huruf Palatino, ukuran 11;

g. Pengutipan kalimat. Kutipan kalimat ditulis secara langsung apabila lebih dari empat baris dipisahkan dari teks dengan jarak satu spasi dengan ukuran huruf 10 point. Sedangkan kutipan kurang dari empat baris diintegrasikan dalam teks, dengan tanda apostrof ganda di awal dan di akhir kutipan. Setiap kutipan diberi nomor. Sistem pengutipan adalah footnote (bukan bodynote atau endnote). Penulisan footnote menggunakan sistem turabian. Setiap artikel, buku, dan sumber lainnya yang dikutip harus tercantum dalam pustaka acuan;

h. Pengutipan Ayat Alquran dan Hadis. Ayat yang dikutip menyertakan keterangan ayat dalam kurung, dengan menyebut nama surah, nomor surah, dan nomor ayat, seperti (Q.s. al-Mu'min [40]: 43). Pengutipan Hadis menyebutkan nama perawi (H.r. al-Bukhārĩ dan Muslim) ditambah referensi versi cetak kitab Hadis yang dikutip. Hadis harus dikutip dari kitab-kitab Hadis standar (Kutub al-Tis'ah);

i. Cara pembuatan footnote. Footnote ditulis dengan font Palation size 9, untuk pelbagai sumber, antara lain: 
1) Buku: nama utuh penulis (tanpa gelar), judul buku (tempat terbit: penerbit, tahun terbit), cetakan, volume, juz, halaman. Contoh: Soerjono Soekanto, Pokok-pokok Sosiologi Hukum, (Jakarta: Rajawali Pers, 1986), h. 10.

2) Buku terjemahan, contoh: Roscoe Pound, Pengantar Filsafat Hukum: Buku III, diterjemahkan oleh Moh. Radjab, (Jakarta: Bharata, 1963), h. 15;

1) Jurnal, contoh: Nur Rohim, "Kontroversi Pembentukan Perppu No. 1 Tahun 2013 tentang mahkamah konstitusi dalam ranah kegentingan yang memaksa", dalam Jurnal Cita Hukum, Vol. 2, No. 1 (2014), h. 157.

2) Artikel sebagai bagian dari buku (antologi), contoh: Hikmahanto Juwana, "Penegakan Hukum dalam Kajian Law and Development: Problem dan Fundamen bagi Solusi Indonesia", dalam Muhammad Tahir Azhary, Beberapa Aspek Hukum Tata Negara, Hukum Pidana, dan Hukum Islam, (Jakarta: Kencana Prenada Media Gorup, 2012), h. 127.

3) Artikel dari internet, contoh: Ahmad Tholabi Kharlie, "Problem Yuridis RUU Syariah" dalam http://ahmadtholabi.com/2008/03/03/problem-yuridis-ruu-syariah, diunduh pada 20 Maret 2012.

4) Artikel dari majalah, contoh: Susilaningtias, "Potret Hukum Adat pada Masa Kolonial", dalam Forum Keadilan, No. 17, 20 Agustus 2006.

5) Makalah dalam seminar, contoh: Jimly Asshiddiqie, "Kedudukan Mahkamah Konstitusi dalam Struktur Ketatanegaraan Indonesia", Makalah disampaikan dalam Kuliah Umum Fakultas Hukum Universitas Sebelas Maret, Surakarta, pada 2 Maret 2004.

j. Pustaka Acuan: daftar pustaka acuan ditulis sesuai urutan abjad, nama akhir penulis diletakkan di depan. Contoh:

1) Buku, contoh: Soekanto, Soerjono, Pokok-pokok Sosiologi Hukum, Jakarta: Rajawali Pers, 1986.

2) Buku terjemahan, contoh: Pound, Roscoe, Pengantar Filsafat Hukum: Buku III, diterjemahakan oleh Moh. Radjab, Jakarta: Bharata, 1963.

3) Jurnal, contoh: Rohim, Nur, "Kontroversi Pembentukan Perppu No. 1 Tahun 2013 tentang mahkamah konstitusi dalam ranah kegentingan yang memaksa", dalam Jurnal Cita Hukum, Vol. 2, No. 1 (2014).

4) Artikel sebagai bagian dari buku, contoh: Juwana, Hikmahanto, "Penegakan Hukum dalam Kajian Law and Development: Problem dan Fundamen bagi Solusi Indonesia", dalam Muhammad Tahir Azhary, Beberapa Aspek Hukum Tata Negara, Hukum Pidana, dan Hukum Islam, Jakarta: Kencana Prenada Media Gorup, 2012.

5) Artikel yang dikutip dari internet, contoh: Kharlie, Ahmad Tholabi, "Problem Yuridis RUU Syariah" dalam http://ahmadtholabi.com/2008/03/03/problem-yuridis-ruu-syariah, diunduh pada 20 Maret 2012.

6) Majalah, contoh: Susilaningtias, "Potret Hukum Adat pada Masa Kolonial", dalam Forum Keadilan, No. 17, 20 Agustus 2006.

7) Makalah dalam seminar, contoh: Asshiddiqie, Jimly, "Kedudukan Mahkamah Konstitusi dalam Struktur Ketatanegaraan Indonesia", Makalah disampaikan dalam Kuliah Umum Fakultas Hukum Universitas Sebelas Maret, Surakarta, pada 2 Maret 2004.

k. Penutup: artikel ditutup dengan kesimpulan;

I. Biografi singkat: biografi penulis mengandung unsur nama (lengkap dengan gelar akademik), tempat tugas, riwayat pendidikan formal (S1, S2, S3), dan bidang keahlian akademik;

6. Setiap naskah yang tidak mengindahkan pedoman penulisan ini akan dikembalikan kepada penulisnya untuk diperbaiki.

7. Naskah sudah diserahkan kepada penyunting, selambat-lambatnya tiga bulan sebelum waktu penerbitan (April, Agustus. dan Desember) dengan mengupload pada laman OJS jurnal pada alamat http://journal.uinjkt.ac.id/index.php/salam atau dikirim langsung via e-mail ke: jurnal.salam@gmail.com atau nurrohimyunus@uinjkt.ac.id..] 
